PRISCILA AKEMI BELTRAME

\title{
TUTELA PENAL DOS DIREITOS HUMANOS E O EXPANSIONISMO PUNITIVO
}

Tese de Doutorado

Orientador: Professor Titular Dr. Miguel Reale Júnior

Faculdade de Direito da Universidade de São Paulo São Paulo

2015 
PRISCILA AKEMI BELTRAME

\section{TUTELA PENAL DOS DIREITOS HUMANOS E O EXPANSIONISMO PUNITIVO}

Tese apresentada à Banca Examinadora do Programa de Pós-Graduação em Direito, da Faculdade de Direito da Universidade de São Paulo, como exigência parcial para obtenção do título de Doutor em Direito, na área de concentração de Direito Penal, sob a orientação do Professor Titular Dr. Miguel Reale Júnior.

Faculdade de Direito da Universidade de São Paulo

São Paulo

2015 
Banca Examinadora: 
À memória de meu pai, Deonil Beltrame. 


\section{AGRADECIMENTOS}

Agradeço ao Prof. Miguel Reale Júnior, meu orientador, mas acima de tudo um professor e mestre das ciências jurídicas e humanas, generoso com seu conhecimento e exigente na mesma medida, por sua confiança, disposição e interesse pela luta travada e compartilhada pelo tema deste trabalho.

Agradeço a professores que dialogaram e acrescentaram conhecimentos, reflexões, referências, especialmente aos relevantes comentários dos membros da banca de qualificação: Prof. Renato Jorge Mello da Silveira, Prof. Alamiro Velludo Salvador Netto. Também aos demais professores e colegas de convívio nas aulas da pós-graduação e acadêmico, Prof. Sérgio Salomão Shecaira, Prof. Xabier Arana, Prof. Luciano Anderson de Sousa, Prof. Masato Ninomiya, Prof. Eduardo Saad-Diniz, João Daniel Rassi, Profa. Deisy Ventura, Ingrid Leão, Fábia Veçoso, Anne-Dorothee Slovic e Iñaki Txoperenac.

Agradeço aos colegas de profissão e amigos que me brindaram com sua generosidade, convivência, reflexões e apoio: Carlos Frederico Barbosa Bentivegna (Cacaio), Paula Camargo, Rafael Mendes Gomes, Rodrigo Vesterman Alcalde, Maria Laura Rossi, Vitor André Lopes da Cruz, Astrid Monteiro de Carvalho Guimarães de Lima Rocha, Melissa Borja, Valquiria Santos Gaudencio da Silva, Ruan Cavalcante e Patrícia Arnaud.

De forma muito especial, por motivos mais pessoais do que acadêmicos, agradeço Maria Lucia Ribeiro Avila Maronna, meus irmãos, Rodrigo José Antonio Beltrame, dedicado leitor, Fernando Antonio Beltrame, minhas quase-irmãs Mariana Avila Maronna, Aline da Rocha Jarozewski e Maria Helena Guedes Crespo. Agradeço meu esteio, uma luz que ilumina minha vida e minhas condições para realizar estre trabalho, minha mãe, Maria Itiko Beltrame.

Agradeço Cristiano Avila Maronna, companheiro nessa jornada, e a nossos filhos Cecília e Antonio. 


\section{SUMÁRIO}

INTRODUÇÃO

CAPÍTULO 1 - EXPANSIONISMO PENAL E DIREITOS

HUMANOS

$1.1 O$ direito penal na globalização 20

1.1.1 Globalização e ampliação do campo penal 20

1.1.2 Constelação de riscos e crise do direito penal 25

1.2. Criminalidade no cenário global 31

1.2.1. Crimes globais e enfrentamentos internacionais 31

1.2.2. Tendências a respeito: internacionalização e interlegalidade 36

1.3. Conformação de um direito penal comum 41

1.3.1. Extraterritorialidade, direito penal e competências compartilhadas 41

1.3.2. Consenso na política criminal 46

1.4. Expansionismo Penal e Direitos Humanos 52

1.4.1 Direito Penal e Direitos Humanos 52

1.4.2 Valores Penais Humanos $\quad 59$

1.4.3.Expansionismo, Internacionalização e Ciência do direito penal 63

CAPÍTULO 2 - DIREITO PENAL INTERNACIONAL -

FORMAÇÃO

$\begin{array}{lr}\text { 2.1 Conceito } & 69\end{array}$

$\begin{array}{ll}\text { 2.2 Rumo a um consenso } & 71\end{array}$

$\begin{array}{ll}\text { 2.3 Dificuldades de harmonização } & 73\end{array}$

2.4 Afirmação Histórica dos Tribunais Militares, Penais Internacionais

Ad Hoc e Mistos $\quad 76$ 
a) Primeiros Antecedentes e Nuremberg: Tribunal Militar

Internacional

b) Tóquio: Tribunal Militar do Extremo Oriente 80

c) Lei $n^{\circ} 10$ do Conselho de Controle Aliado 81

2.4.2 Tribunais Ad Hoc

a) Iugoslávia: Tribunal Penal Internacional para a ex-Iugoslávia 83

b) Ruanda: Tribunal Penal Internacional para Ruanda 87

2.4.3. Tribunais Mistos Ad Hoc $\quad 91$

a) Serra Leoa: Tribunal Especial para Serra Leoa 91

b) Timor Leste: Sessão Especial dos Crimes Graves para o

Timor Leste $\quad 92$

c) Camboja - Câmaras Extraordinárias no Tribunal do Camboja 93

d) Kosovo: Tribunal da Guerra do Kosovo e Crimes Étnicos 93

e) Líbano: Tribunal Especial para o Líbano ou "Tribunal Hariri” 93

$\begin{array}{ll}\text { 2.5 Tribunal Penal Internacional } & 95\end{array}$

2.5.1 Breve Histórico 95

2.5.2 O princípio da complementaridade das jurisdições e sua evolução 98

$\begin{array}{ll}\text { 2.6 Justiça de Transição } & 103\end{array}$

$\begin{array}{ll}\text { 2.6.1 Conceito } & 103\end{array}$

2.6.2 Direito à Verdade, Anistia e o Direito Penal para a Justiça de $\begin{array}{ll}\text { Transição } & 108\end{array}$

2.6.3 Justiça de Transição e a Contenção da Perspectiva Punitivista 118

2.7 O sistema latino-americano de proteção de direitos humanos e o direito penal internacional 


\section{CAPÍTULO 3 - DIREITO PENAL INTERNACIONAL -}

ELEMENTOS 130

3.1. Crimes Internacionais vs. Crimes de Direito Internacional 130

3.1.1 Aspectos Gerais e Definição $\quad 130$

3.1.2 Crimes contra o direito internacional $\quad 135$

3.1.3 Conflito na consolidação do direito penal internacional 137

3.2 O direito penal internacional e suas fontes 140

3.2.1 A questão da norma costumeira em direito penal internacional $\quad 140$

3.2.2 Princípios Gerais de Direito em Direito Penal Internacional 149

3.3 O TPI e a interpretação das normas de direito penal

$\begin{array}{ll}\text { internacional } & 156\end{array}$

3.3.1 Interpretação no direito penal internacional 156

3.3.2 O direito penal internacional e o recurso à analogia 158

3.4. Principais Elementos de Direito Penal Internacional 162

3.4.1 A evolução do conceito de responsabilidade individual em DPI 162

3.4.2 A crítica aos elementos do direito penal internacional 166

a) Norma costumeira pro societate 166

b) Princípio da Legalidade 168

c) O DPI e o Ius Cogens 171

d) Jurisdição Universal 173

3.5 O direito penal internacional e a teoria do bem jurídico 181

3.5.1 Aspectos Gerais do Bem Jurídico em DPI 181

3.5.2 Direitos Humanos não são bens jurídicos 184

3.5.3 A problemática da teoria do bem jurídico em relação aos crimes $\begin{array}{ll}\text { do direito penal internacional } & 188\end{array}$

3.5.4 Expansão do direito penal e enfraquecimento da teoria do bem jurídico 194 


\section{CAPÍTULO $4^{\circ}$ - O DIREITO DE PUNIR INTERNACIONALMENTE E}

SUA CRÍTICA 198

4.1 Premissas do Direito de Punir Internacionalmente 198

4.1.1. Considerações sobre a origem do direito de punir 198

4.1.2 Expansionismo e o DPI das Cortes 201

4.2 Tendências Críticas ao Expansionismo Penal do DPI 203

4.2.1 Entre direitos e perplexidades $\quad 204$

4.2.2 Liberalismo e o DPI: justiça substantiva e assimetrias 209

_4.2.3 Responsabilidade individual vs. Contexto Sócio-Político 215

4.2.4 Efeito preventivo dos julgamentos internacionais 217

4.3 Fraturas Expostas do DPI 223

4.3.1 Direito Universal vs. Moral Universal 223

4.3.2 Objetivos e Realizações: ativismo judicial 226

4.3.3 O braço penal dos direitos humanos 232

$\begin{array}{ll}\text { CONCLUSÃO } & 239\end{array}$

$\begin{array}{ll}\text { RESUMO } & 248\end{array}$

$\begin{array}{ll}\text { ABSTRACT } & 249\end{array}$

$\begin{array}{ll}\text { RESUMÉ } & 239\end{array}$

BIBLIOGRAFIA

2391 
"Que tempos modernos chegam,

Depois de tão dura prova?

Quem vai saber, no futuro,

De que alma vai ser feita

Essa humanidade nova?"

(Cecília Meireles, Romanceiro da

Inconfidência, "Romance LIX - da reflexão

dos justos") 


\section{LISTA DE ABREVIATURAS}

$\mathrm{CNU}$

CDI

$\mathrm{CEDH}$

CICGLH

CIDFP

$\mathrm{CIDH}$

CIJ

$\mathrm{ComIDH}$

CorteIDH

DPI

ETPI

ONU

TEDH

TMI

TMIEO

TPI

TPII

TPIR
Carta das Nações Unidas

Comissão de Direito Internacional

Corte Europeia de Direitos Humanos

Convenção sobre a Imprescritibilidade de

Crimes de Guerra e Lesa Humanidade

Convenção Interamericana sobre o

Desaparecimento Forçado de Pessoas

Convenção Americana de Direitos

Humanos

Corte Internacional de Justiça

Comissão Interamericana de Direitos

Humanos

Corte Interamericana de Direitos

Humanos

Direito Penal Internacional

Estatuto do Tribunal Penal Internacional

Organização das Nações Unidas

Tribunal Europeu de Direitos Humanos

Tribunal Militar Internacional (Tribunal

de Nuremberg)

Tribunal Militar Internacional para o

Extremo Oriente (Tribunal de Tóquio)

Tribunal Penal Internacional

Tribunal Penal Internacional para a Ex-

Iugoslávia

Tribunal Penal Internacional para Ruanda 


\section{INTRODUÇÃO}

O trabalho em torno do direito penal internacional nos últimos 20 anos promoveu essa recente área a um novo patamar, que vinha embrionário desde a II Guerra Mundial e os Tribunais Militares Internacionais, mas que recentemente ganhou grande impulso pela importância da jurisprudência dos tribunais $a d$ hoc, seus estatutos, e a aprovação do Estatuto de Roma do Tribunal Penal Internacional, que entrou em vigor dia $1^{\circ}$ de julho de 2002 como o primeiro tribunal penal internacional permanente na história.

Paralelamente a este movimento, testemunhamos a expansão do direito penal adaptado à proteção dos direitos humanos, em alta carga diante da gravidade dos fatos sob a caracterização de crimes de direito internacional. Nosso ponto de partida é o de que os direitos humanos servem como catalisadores para a tendência expansiva do direito penal, especialmente dentro do direito penal internacional, integrando valores comuns da humanidade, globalização e repressão por meio de novas instituições globais.

Nesta nova complexidade normativa, os Estados já não podem mais se proteger atrás das regras de soberania em face dos mais graves crimes, assim como o direito penal tem suas garantias flexibilizadas diante dos ditames da justiça substancial. O âmbito internacional passou a conduzir a convergência discursiva e simbólica de dois ramos jurídicos distintos: o direito penal e os direitos humanos, numa tendência comum da lei de super-prometer $^{1}$ e o excesso legislativo no âmbito internacional, além das obrigações de processar criminalmente que, num contexto de instabilidade política, tende a reduzir as chances de paz, estabilidade e justiça ${ }^{2}$. Por outro lado, também pode-se defender que os mecanismos legais internacionais forjam a construção de ganhos democráticos internamente e que o direito internacional e as organizações internacionais seriam os veículos primários para a afirmação do corpo normativo de uma comunidade e de legitimação coletiva, por

\footnotetext{
${ }^{1}$ KENNEDY, David. The dark sides of virtue: reassessing international humanitarism. Nova Jersey, Princeton Univ. Press, 1999, p. 1073. No original, "the law's own tendency to over-promise".

${ }^{2}$ HELFER, Laurence R. "Forum Shopping for Human Rights", University of Pensylvania Law Review, 148(2), 285, 1999. HELFER, Laurence R. "Overlegalizing Human Rights: International Relations Theory of the Commonwealth Caribbean Backlash Against Human Rights Regimes", Columbia Law Review, 102:1832, p. 44, 2002.
} 
meio do qual promove-se um processo legal transnacional que fincará raízes nas instituições e práticas domésticas.

O diálogo estabelecido entre o direito penal e os direitos humanos, mediado no contexto escolhido deste trabalho, do direito internacional, leva a uma relação desarmônica, tendo como efeito a mudança da prática local, geralmente orientada pela flexibilização das garantias clássicas para a realização da justiça substancial. Trataremos do processo de construção e afirmação do direito penal internacional e da captura dos instrumentos de direito penal pelo discurso de proteção dos direitos humanos para chegarmos num complexo normativo disfuncional, numa integração artificial e num incoerente de proteção de valores.

\section{I}

O primeiro capítulo é dedicado à avaliação das condições presentes para a expansão do direito penal e a aproximação do direito penal com os direitos humanos, tanto em termos teóricos quanto reais, que abrirá caminho para os capítulos seguintes sobre crimes contra a humanidade e a criminalização dos direitos humanos. Para tanto, refletiremos sobre os desafios postos ao direito penal, crises relacionadas à sua capacidade de gestão das novas categorias de crime, suas tendências expansivas e sua organização em torno de valores universais. O segundo capítulo percorre os momentos históricos e teóricos de afirmação do direito penal internacional, tratando também da justiça de transição como uma possível perspectiva para si. Aprofundamos os institutos do direito penal internacional no terceiro capítulo, assim como as discussões sobre as fontes de direito penal internacional, a base costumeira em face do princípio da legalidade da norma penal, as condições e precauções em torno da justiça universal e afirmação do ius cogens internacional penal. O último capítulo aborda a difícil harmonização entre os pressupostos expansivos dos direitos humanos e a natureza contentora intrínseca do direito penal.

Antes, porém, há que se fazer uma breve sistematização do que se entende por expansão do direito penal e do que se entende por direitos humanos. De modo sucinto, por direitos humanos, entendemos ser uma potente convenção terminológica, de cunho políticojurídico, como caminho para a construção da dignidade humana, baseada na liberdade (plano 
cultural), fraternidade (plano político) e igualdade (plano social) ${ }^{3}$. Há concepções legalistas ${ }^{4}$, outras relativas à capacidade de reivindicações ${ }^{5}$, outras ontológicas ${ }^{6}$ : todos são titulares de direitos humanos pelo fato de serem seres-humanos (direitos de igualdade, que todos têm por serem igualmente seres-humanos), e, portanto, inalienáveis e universais, incluindo o sujeito e a norma como parte do conceito de direitos humanos. Nesse sentido, os valores inscritos pelos direitos humanos iluminam todo o ordenamento jurídico ao mesmo tempo que representam compromissos assumidos pelo Estado brasileiro perante a ordem internacional ${ }^{7}$, como inscrito na Declaração Universal dos Direitos Humanos (1948), art. 28, ao afirmar que "toda pessoa tem direito a que reine, no plano social e no plano internacional, uma ordem capaz de tornar plenamente efetivos os direitos e as liberdades enunciadas" na declaração.

Por expansão do direito penal, entendemos o fenômeno assinalado por SILVA SÁNCHEZ ${ }^{8}$ de aparição de novos tipos penais em diversos ordenamentos jurídicos, uma expansão não apenas quantitativa (novos tipos penais e agravação das penas), mas essencialmente qualitativa (reinterpretação das garantias clássicas, acomodações à teoria do bem jurídico, flexibilização das regras de imputação e relativização dos princípios políticocriminais). $\mathrm{O}$ autor defende que a expansão ocorra segundo critérios racionais, com base na demanda popular de mais proteção, ao contrário do uso simbólico e populista da repressão penal. A expansão, em decorrência disso, abrange reflexamente a globalização e a integração

\footnotetext{
${ }^{3}$ HERRERA FLORES, Joaquín. "Cultura y derechos humanos: la construcción de los espacios culturales”. In MARTÍNEZ, Alejandro Rosillo (et al., eds.). Teoria Crítica dos Direitos Humanos no Séc. XXI, Porto Alegre: Edipucrs, 2008, pp. 262 ss.

${ }^{4}$ BRYSK, Alisson. Globalization and Human Rights, Berkeley, CA: University of California Press, 2002, p. 3.

${ }^{5}$ GOODALE, Mark. The practice of human rights. Tracking law between the global and the local. Cambridge: Cambridge Univ. Press, 2003, p. 6.

${ }^{6}$ DONELLY, Jack. Universal Human Rights in Theory and Practice. Ithaca: Cornell Univ. Press, 2003, p. 10. De maneira semelhante, VERGÉS RAMÍREZ, Salvador. Derechos humanos: fundamentación. Madri: Tecnos, 1997.

${ }^{7}$ COMPARATO entende que a tendência predominante é a de se considerar que as normas internacionais de direitos humanos, pelo fato de exprimirem uma consciência ética universal, estão acima dos ordenamentos jurídicos de cada Estado e que a proteção da dignidade humana é a finalidade última e razão de ser de todo o sistema jurídico. O sistema de direitos humanos é de duas ordens para o autor: conforme digam respeito aos valores éticos supremos ou à lógica estrutural do conjunto. Em todo caso, elas dão coesão ao sistema jurídico como um todo e permitem a correção de rumos em caso de conflitos internos ao sistema ou transformações externas. COMPARATO, Fábio Konder. A afirmação histórica dos direitos humanos. São Paulo: Ed. Saraiva, 1999, pp. 48-49.

${ }^{8}$ SILVA SÁNCHEZ, Jesús-María. La expansión del derecho penal. Aspectos de la política criminal en las sociedades postindustriales, Civitas, $2^{\mathrm{a}}$ ed., 2001. A expansão é tema de discussão por diversos autores, dentro do direito penal de intervenção, de Winfred Hassemer, ou dos autores da Escola de Frankfurt (Naucke, Lünderssen, Albrecht e Prittwitz), além dos autores que defendem a necessidade de intervenção criminal referente à criminalidade econômica, como Schünemann, Tiedemann, entre outros.
} 
supranacional relacionadas ao direito penal na área dos direitos humanos. Assim, trata-se de promover progressivamente as modificações dos critérios de aplicação da lei penal no espaço, a indicar a crise do princípio de territorialidade, "frente ao qual se pretende abrir novos âmbitos de incidência do princípio de proteção e ao de justiça universal"9.

O movimento do direito penal em direção ao campo internacional sofre a influência de cinco maiores perspectivas, tratadas ao longo deste primeiro capítulo: globalização econômica, aspectos relacionados à sociedade do risco, construção de uma comunidade universal em torno de valores protegidos pelos direitos humanos, coordenação de instituições supranacionais e a própria revisão por que passa o direito penal em direção à sua expansão. O equacionamento destes vetores modulará o direito penal do futuro, para alguns autores, com redução das garantiras e ampliação do alcance das normas penais, para outros um caos jurídico, uma maior integração entre as nações, colaborando para a construção de um sistema protetivo de direitos humanos que contribua para a própria emergência de um direito penal supranacional.

O direito penal, como manifestação repressiva do poder estatal, tem apresentado, mais modernamente, tendência de avanço para o campo internacional, especialmente na área dos direitos humanos. A reboque do fenômeno da mundialização das relações sociais, econômicas, culturais, o complexo jurídico espraia-se para além dos domínios do estadonação e conforma uma nova razão jurídico-penal que justifique a atuação do assim chamado direito penal internacional.

A criação dos espaços jurídico-penais internacionais deve ser entendida nessa perspectiva das inter-influências, ao mesmo tempo em que os mecanismos de justiça de transição, as cortes internacionais penais, a cooperação internacional em matéria penal e as formas de internacionalização do direito passam a compor este cenário. Atualmente considera-se a dupla dimensão na órbita do direito internacional público a construir o espaço de incidência do direito penal internacional: de um lado, a comunidade internacional composta por Estados soberanos e de outro, a comunidade internacional como grupo social

\footnotetext{
${ }^{9}$ SILVA SÁNCHEZ, Jesús-María. La expansión del derecho penal: aspectos de la política criminal en las sociedades postindustriales. Madri: Civitas, $2^{\mathrm{a}}$ ed., 2001, nota 255, pp. 101-102.
} 
universal com interesses próprios ${ }^{10}$, trafegando o presente tema de um lado a outro. No concerto entre os Estados, a aplicação das normas de direito penal internacional, a adesão aos tratados e a cooperação para efetivação das normas, favorece a emergência de valores universais de proteção internacional e influencia também a atuação do direito penal para a garantia do objetivo comum, a manutenção da ordem social e da paz.

Em nossa visão, o fortalecimento dos direitos humanos não passa pela criminalização das condutas, com apoio nas teorias criminológicas que criticam o uso do direito penal como parte do aparato de segurança do Estado. Da mesma forma, os direitos humanos e o direito penal também atuam em sinergia, comunicando entre si suas forças e seus princípios, no que CARVALHO ${ }^{11}$ expõe como a reversibilidade do discurso e inversão ideológica do sentido histórico dos direitos humanos no campo das práticas punitivas.

O percurso do capítulo demonstra que a globalização econômica favorece a integração dos Estados na construção de uma ética mundial, veiculada pelo discurso dos direitos humanos. De maneira concomitante, as práticas criminais beneficiam-se da maior integração propiciada pela globalização e interconexão das sociedades para organizarem categorias de crimes ao redor do mundo. A comunidade de valores e a erosão da capacidade do Estado em enfrentar o problema da criminalidade transnacional, ressaltado pela teoria da sociedade do risco, destaca um novo papel ao direito penal: a busca de novos fundamentos de existência, novas categorias de bens jurídicos, orientando sua expansão.

A internacionalização da intervenção penal impacta tanto o edifício jurídico que um dos atributos fundamentais do Estado, o direito de punir, manifestação direta da soberania, é transferido à outra jurisdição supranacional, a jurisdição internacional. Assim, a definição de crime internacional e crime contra a humanidade é essencialmente a razão de ser das Cortes Internacionais Penais e do Tribunal Internacional Penal, em última instância. Conforme adverte DELMAS-MARTY"12, "a proteção dos direitos humanos marca, primeiramente, os limites do poder de punir dos Estados (recurso de incriminar, mas também

\footnotetext{
${ }^{10}$ GIL GIL, Alicia. Derecho penal internacional. Madri: Tecnos, 1999, p. 34.

11 CARVALHO, Salo de. "Criminologia, Garantismo e Teoria Crítica dos Direitos Humanos". In: MARTÍNEZ, Alejandro Rosillo (et al., eds.). Teoria crítica dos direitos humanos no século XXI, Porto Alegre: Edipucrs, 2008, pp. 494-5.

12 DELMAS-MARTY, Mireille; CASSESE, Antonio. Crimes Internacionais e Jurisdições Internacionais. Barueri: Ed. Manole, 2004, p. 306.
} 
condição de instauração dos processos, da produção da condenação, da escolha e execução das penas), logo os limites ao movimento de penalização".

Pelo quanto exposto, identifica-se a necessidade de se chegar a uma abordagem estrutural dos elementos que compõem o direito penal internacional, a partir do exame dos diversos mecanismos criados no corpo da proteção internacional dos direitos humanos, especialmente para processamento e punição dos crimes contra a humanidade. Trata-se de uma abordagem crítica aplicada dos pressupostos de afirmação dos direitos humanos, dando nova perspectiva de recurso ao direito penal no campo das relações internacionais. Essa construção corre em paralelo à preocupação de que a proteção dos direitos humanos e o consequente expansionismo punitivo contribuiria para o processo de tornar o direito mais autoritário, com a respectiva, gradual e constante redução do âmbito de incidência das liberdades, influenciando o direito penal nacional ao recepcionar as tendências das cortes internacionais. O campo das garantias instrumentaliza-se consoante o programa de afirmação dos direitos humanos.

O programa de afirmação do direito penal internacional percorre os seguintes elementos: a) fortalecimento dos valores comuns da humanidade e consolidação na norma a função preventiva de crimes; b) fortalecimento das condições para a paz por meio da aplicação das penas (função retributiva) para responsabilizar e punir os violadores das regras da humanidade, reduzindo a propensão social à vingança privada; c) obrigações positivos dos Estados de reparação das violações sofridas pelas vítimas, por meio de indenizações pelos danos e prejuízos experimentados; d) produção de memória dos fatos julgados, fazendo dos relatos uma parte da realidade social ${ }^{13}$.

Apontaremos neste trabalho as fragilidades de cada um destes elementos, possibilitando a visão em perspectiva de um tema conflituoso. Questionamos a existência da função preventiva da norma, quando inexiste a percepção ampla de que os crimes de direito internacional serão de fato julgados internacionalmente, sendo muito mais poderoso o

\footnotetext{
${ }^{13}$ Conforme adaptado dos objetivos de orientação valorativa do direito penal internacional, apresentado por BASSIOUNI, M. Cherif. "International Criminal Justice in the Age of Globalization", International Criminal Law: Quo Vadis, AIDP, nº. 19, 2004, p. 153.
} 
contexto local que determina a comissão dos graves crimes do que perspectiva de aplicação da norma internacional. No mais, os julgamentos também mostraram outra face da aplicação do direito penal internacional: falta de sensibilidade para os argumentos jurídicos das defesas, flexibilização das garantias diante da aplicação da norma substantiva de direitos humanos, contraposição (inexistente) entre direitos humanos e garantias penais e processuais penais, aplicação seletiva da justiça.

\section{IV}

Ressaltamos que o direito penal e sua forma de atuar, como o concebemos, é uma ferramenta impotente para enfrentar o crime internacional, e que o direito penal internacional como está, além de não se mostrar eficaz, prejudica os marcos civilizatórios que o direito penal alcançou por meio dos princípios da mínima intervenção, fragmentaridade e de ultima ratio. Portanto, também aqui, torna-se fácil o discurso do "populismo antigarantista", no qual as garantias fundamentais são facilmente reduzidas a um mínimo em prol da eficiência da punição, ironicamente sob o fundamento de proteção dos direitos humanos.

Alertamos que a expansão do direito penal não se faz apenas pela ampliação formulação de novos delitos ou de bens jurídicos, mas sobretudo pela redução de princípios, de condições para a imputação objetiva e subjetiva, que não se conforma mais com o "papel tradicional da busca justa e exemplar pela responsabilidade individual"14. Conquanto até agora o direito penal seja concebido como uma ciência nacional ${ }^{15}$, como expressão do poder de soberania sobre seus cidadãos, novas perspectivas e rearranjos internacionais podem alterar esta concepção, catapultados sobretudo pela afirmação institucional dos direitos humanos.

\footnotetext{
${ }^{14}$ PRITTWITZ, Cornelius. "A função do direito penal na sociedade globalizada do risco - defesa de um papel necessariamente modesto". In: AMBOS, Kai; BÖHN, María Laura (coords.). Desenvolvimentos atuais das ciências criminais na Alemanha. Gazeta Jurídica: Brasília, 2013, p. 58.

${ }^{15}$ Em igual sentido, FIGUEIREDO DIAS, Jorge de. Direito Penal - Parte Geral, Ed. Revista dos Tribunais e Coimbra Editora, 2007, pp. 10 e ss. "O direito penal é ainda hoje essencialmente direito intra-estatal, que encontra a sua fonte formal e orgânica na produção legislativa estadual e é aplicado por órgãos nacionais. Todavia, a partir da última década do séc. XX assistiu-se a um prodigioso incremento da relevância do direito internacional no direito penal" (grifos no original).
} 
Crime e persecução penal são temas ainda melhor localizados e resolvidos na esfera judicial nacional e para o direito penal internacional progredir em termos técnicos e dogmáticos, não pode se afastar de uma construção que atue no máximo padrão de garantias e direitos daqueles que são objeto do poder punitivo, os ofensores. Os valores comuns da humanidade pressupõem uma elaboração teórica para a concepção do princípio do cidadão mundial, cuja consequência é a de legitimar a persecução criminal das máximas violações aos direitos humanos, que deverá ocorrer, para HABERMAS, dentro do ordenamento estatal.

Os direitos humanos deveriam atuar não apenas como orientação moral da ação política, mas também como direitos subjetivos a serem implementados por normas jurídicas, conforme o autor. Apenas quando os direitos tenham encontrado seu lugar, num ordenamento jurídico global, como os direitos fundamentais estão plasmados social e juridicamente nas Constituições, "poderemos também partir para o plano global, quando os destinatários destes direitos possam ser considerados, ao mesmo tempo, como seus autores"16.

${ }^{16}$ HABERMAS, Jurgen. Die Zeit, de 29 de abril de 1999, citado por AMBOS, Kai. Temas de Derecho Penal Internacional y Europeo. Madri: Marcial Pons, 2006, p 27 (trad. livre). 


\section{CAPÍTULO 1 - EXPANSIONISMO PENAL E DIREITOS HUMANOS}

\subsection{O direito penal na globalização}

\subsubsection{Globalização e ampliação do campo penal}

O direito penal tem sofrido as influências perturbadoras das novas dinâmicas sociais infundidas pela globalização, particularmente com o compartilhamento de valores mundiais comunicados pelos direitos humanos e com a desorganização na forma de responder aos desafios. Desafios relacionados a renovações dos conceitos clássicos de soberania estatal e a princípios como a legalidade em direito penal internacional são enfrentados pelo direito penal moderno. Entre as distintas posições a respeito da influência da globalização no direito penal, do ceticismo que enxerga a flexibilização das garantias até a defesa dos interesses da humanidade, existe um arranjo improvável de variáveis dissonantes.

Globalização é um veículo de oportunidades, mas também de incertezas. A criação do Tribunal Penal Internacional e a consolidação da jurisdição universal é uma tentativa de resposta a essas incertezas, que necessariamente se relacionam com o compartilhamento de valores comuns e a falta de meios de concretizar essa mesma base de valores. A irrealização desses valores está conectada ao que Ulrich BECK chamou de irresponsabilidade organizada da sociedade de risco.

É certo que as pessoas localizam a questão da segurança entre as suas prioridades ${ }^{17}$, associada à forma como o Estado responderá aos novos desafios relacionados à segurança, tendo em vista a perda do poder estatal e a necessidade de concertos jurídicos

\footnotetext{
${ }^{17}$ Pirâmide de Maslow, MASLOW, Abraham. “A Theory of Human Motivation”, Psycological Review, 1943, 50, pp. 370-396, na qual o primeiro nível de necessidade corresponde às necessidades fisiológicas e a segunda à segurança.
} 
internacionais num mundo globalizado ${ }^{18}$. Por outro lado, o Estado, como único órgão com monopólio do recurso à violência, deve estar preparado para contornar sua impotência diante dos desafios trazidos pelos novos riscos e a nova forma de organização das sociedades.

Não se trata, no presente trabalho, de discutir a criminalidade global, ou de discorrer sobre se se trata de manifestações locais ou de mega-organizacões criminosas impulsionando o fato criminoso para além das fronteiras nacionais e navegando nos recursos facilitados pela globalização (físicos, financeiros, informáticos), mas de refletir sobre as condições que fizeram nascer essa comunidade de valores ${ }^{19}$ a ponto de fundamentar a reunião de Estados em torno de um projeto de cidadania mundial que culminasse na validade e alcance da jurisdição universal. Se a globalização não necessariamente trouxe uma nova criminalidade, ela sem dúvida traz elementos para se questionar os limites do direito penal tradicional diante de uma realidade complexamente conectada, movimentando diferentes pontos do planeta, com uma facilidade jamais vista de trânsito em termos de pessoas,

\footnotetext{
${ }^{18}$ STIGLITZ, Joseph, El mal estar en la globalización (Trad. Carlos Rodríguez Braun). Madrid: Taurus, 2002, para uma abordagem econômica do fenômeno e CAPELLA HERNÁNDEZ, J. R., "La naturaliza de la mundialización". In: CAPELLA HERNÁNDEZ, J. R. (ed.). Transformaciones del derecho en la mundialización, Madri: Consejo General del Poder Judicial, 1999, pp. 13-81, para uma abordagem históricojurídica. A doutrina tem distinguido os termos globalização de mundialização, identificando que a mundialização é o processo de integração das sociedades num primeiro momento, isoladas e com pouco contato entre si, a partir do séc. XV, impulsionado inclusive pela Cristandade Medieval, por meio da expansão, conquista e colonização dos povos, até a situação de franca integração das nações, ao redor de uma sociedade mundial, conforme ARENAL, Celestino del, "Mundialización, cresciente interdependência y globalización", conferências, Univ. Complutense de Madrid, p. 197, disponível em http://www.ehu.es/cursosderechointernacional vitoria/ponencias/pdf/2008/2008_4.pdf (Acesso 11.8.2012). Por outro lado, a globalização seria apenas a etapa final desse processo, marcada pela crescente interdependência, que conforme entendido atualmente, é bastante recente, tanto do ponto de vista quantitativo quanto qualitativo. "Tal como la entendemos hoy día, es decir, en cuanto afecta a un conjunto de procesos y ámbitos muy diferentes a escala planetaria y supone actuar en unas condiciones situadas más allá de las dimensiones espacial y temporal y en el que las distancias se cubren de forma inmediata, la globalización sólo tiene lugar a partir de los años setenta o a partir de principios de los años ochenta, en directa relación, por un lado, con la revolución en el campo de la información y la comunicación que se inicia en esos momentos $y$, por otro, con la transformación fundamental que experimenta a partir de los años setenta el sistema capitalista mundial.", conforme ARENAL, p. 217. Entretanto, em algumas obras podemos observar que o uso é feito indistintamente, como em TERRADILLOS BASOCO, "El derecho penal de la globalización: luces y sombras". In: CAPELLA HERNÁNDEZ, J. R. (ed.). Transformaciones del Derecho en la mundialización, op. cit., 185-217, o próprio CAPELLA HERNÁNDES, J.R.,"La naturaleza de la mundialización”, op. cit., ou DELMAS-MARTY, M., "O direito penal como ética da mundialização", Revista portuguesa de ciência criminal, A.14, nº 3, Jul./Set. 2004, pp. 287-304, entre outros.

${ }^{19}$ SILVA SÁNCHEZ, Jesús-María. La expansión del derecho penal (...), op. cit., pp. 92-93. “A adoção dessa perspectiva pode permitir dotar o sistema do direito penal de um inegável caráter supranacional, se se toma como ponto central de referência a comunidade cultural e de valores subjacentes às constituições ocidentais atuais. Mas isso implica um fator de relativização. Uma ciência do direito penal baseada exclusivamente nas estruturas lógico-objetivas, ou que se limite a construir o sistema de problemas ou de estruturas de imputação pode ser plenamente universal. Ao contrário, uma ciência com traços teleológicos-valorativos, se pode bem ser supranacional, independentemente dos ordenamentos jurídicos nacionais, não pode alijar-se das culturas, dos sistemas de representações valorativas: tem, portanto, óbvios condicionantes espaço-temporais" (trad. livre).
} 
recursos financeiros, de informação e de jurisdições. Nas palavras de Luciano Anderson de SOUZA, essa intensidade de circulação de ativos que em termos de criminalidade se reflete nos "elementos de organização, transnacionalidade e poderio econômico, deixa perplexas e ineficazes, respectivamente, as autoridades e os mecanismos estatais de controle, tradicionalmente voltados para a prevenção e repressão ao criminoso individual"20.

Não acreditamos que esse fenômeno diga respeito apenas aos elementos de conexão ${ }^{21}$ entre diversas jurisdições que de forma mais intensa passam a fazer parte dos crimes comuns, mas que efetivamente essa conformação das novas relações sociais em escala mundial facilita de modo geral todo tipo de atividades transacionais, mais especificamente, as próprias das atividades criminais. Estas, desse modo, beneficiam-se da estrutura e limites da justiça penal, inclusive da dificuldade de persecução ${ }^{22}$.

Como afirmado por Joachim VOGEL ${ }^{23}$, não cabe às ciências jurídicas definir o termo globalização, justamente por não ser um conceito jurídico, mas social, sociológico, histórico; cabe, sim, ao direito, refletir sobre os seus impactos nas relações sociais e buscar um posicionamento de como estes serão enfrentados pelos respectivos sistemas jurídicos. De interessante menção, os cinco pontos enunciados por VOGEL sobre o que compreende a referência à globalização: em termos econômicos, político descritivo, político normativo, geral objetivo e geral subjetivo.

- Em termos econômicos, a globalização se reflete na gênese de mercados globais nos quais os agentes econômicos, em particular, as empresas transnacionais na qualidade de global players, movem-se com liberdade em escala mundial, e nos quais, em princípio, capital, trabalho e serviços podem se mover livremente, o que é possível graças aos avanços técnicos (de transportes, de informação e de comunicações).

\footnotetext{
${ }^{20}$ SOUZA, Luciano Anderson de. Expansão do Direito Penal e Globalização, São Paulo: Quartier Latin, 2007, p. 26.

${ }^{21}$ Trata-se de um conceito caro no âmbito do direito internacional privado. Em italiano, punto de collegamento, na França, point de rattachement, na Espanha, circunstancia de conexión, como uma técnica de identificar o direito aplicável. São as diretrizes para dirimir o conflito de leis. STRENGER, Irineu. Direito Internacional Privado, vol. 1, São Paulo: Ed. Revista dos Tribunais, 1986, pp. 265-266.

${ }^{22}$ CUESTA, J. L. de la, "Retos y perspectivas del sistema penal en un mundo globalizado", Revista Académica de la Facultad de Derecho de la Univ. de la Salle, IV, 7 de julho, 2006, pp. 274 ss.

${ }^{23}$ VOGEL, Joachim. "Derecho Penal y Globalización" (trad. Manuel Cancio Meliá), AFDUAM, 9, 2005, p. 114. Segundo o autor, "globalización no es un concepto jurídico, y yo como jurista no pretendo decir algo original o propio a respecto”. Assim, a globalização não apenas não é um conceito jurídico, como prescinde do próprio direito para se conformar.
} 
- No plano político-descritivo, a globalização se refere à perda de relevância política (mundial) que sofrem os Estados nacionais (the breaking of nations), e a gêneses de mecanismos de governança global.

- No plano político-normativo, a globalização se reflete na orientação política com base nos interesses do mundo em seu conjunto, na humanidade, e não em interesses nacionais;

- Do ponto de vista geral objetivo, a globalização corresponde à "aproximação do mundo", a gênese de uma comunidade de destino global com os três subaspectos: de uma comunidade da violência (da perspectiva do autor), uma comunidade de necessidade e sofrimento (da perspectiva da vítima) e uma comunidade de cooperação (da perspectiva internacional, do sistema); e

- Do ponto de vista geral subjetivo, a crescente consciência do mundo como um todo, a gênese de uma ética mundial.

O fenômeno da globalização, portanto, reduz as distâncias físicas ${ }^{24}$ e de valores que orientam as sociedades e, juntamente com a erosão do Estado nação ${ }^{25}$, destacam um novo papel ao direito penal: equacionar as novas categorias de bens jurídicos, buscar novos fundamentos de existência, inclusive imbuído da missão de um direito penal que apesar dele consiga gerar consenso e reforçar a comunidade ${ }^{26}$, mas que também, apoiado nos valores comuns da humanidade, fortaleça-se pela sua dimensão preventiva ${ }^{27}$. A apreensão destes

\footnotetext{
${ }^{24}$ Nesse sentido, FARIA, José Eduardo, O direito na economia globalizada, São Paulo: Ed. Malheiros, 2004, p. 61, enfatizando inclusive a substituição do Estado pelas empresas privadas e a instauração de uma nova forma de ordenação sócio-econômica e regulação político-normativa.

25 Octavio IANNI localiza essa questão no que chamou de emergência de uma sociedade global, tanto metodológica quanto empiricamente: "pode ser vista como um todo abrangente, complexo e contraditório, subsumindo formal ou realmente a sociedade nacional", A Era do Globalismo. Rio de Janeiro: Ed. Civilização Brasileira, 1997, p. 99.

${ }^{26}$ SILVA SÁNCHEZ, Jesús-María. A expansão do Direito penal: aspectos da política criminal nas sociedades pós-industriais. São Paulo: Revista dos Tribunais, 2002 (Série as Ciências Criminais no Século XXI; v. 11), p. 41.

${ }^{27}$ SILVA SÁNCHEZ, Jesús-María. A Expansão do direito penal (...), op. cit., para quem o efeito preventivo está no significado comunicativo da norma penal. "Um fator que permite a manutenção dos níveis tanto de prevenção dissuasória como de contenção de reações informais, como, enfim, de prevenção de integração, sem necessidade de aumentar o sofrimento efetivo dos sujeitos afetados pela intervenção do direito penal” (p. 73).
} 
fatores enunciados por VOGEL praticamente nos remete à consideração de que passa a existir também para o direito uma nova coletividade de interesses e que as ciências jurídicas não podem deixar de atentar para essa conformação potente que se molda, internacionalizada, cujo catalisador em diversas dimensões é a defesa dos direitos humanos.

Comumente, a globalização é tratada como um novo ciclo do capitalismo ${ }^{28}$, ou como uma nova forma de divisão internacional do trabalho, baseada na alocação global de recursos ${ }^{29}$ possibilitada pela construção de impérios empresariais que do jogo dos benefícios mundialmente calculados articula sua produção e seus riscos. Essa interconectividade de meio e de mensagem, de forma e conteúdo, de pessoas e instituições que permitem um funcionamento global constitui, nas palavras de um dos principais teóricos da globalização, Manuel CASTELLS, uma unidade em tempo real e em escala mundial ${ }^{30}$. Além do intenso aumento dos intercâmbios econômicos e comerciais a que se assistiu no final do século, decorrente de uma diversidade de fatores, favoreceu a abertura dos mercados de capital, a aproximação do Ocidente do Oriente, a melhora tecnológica das comunicações e dos meios de transporte, o favorecimento de uma interdependência econômica em escala mundial, os movimentos migratórios intensificados, mas especialmente o pouco grau de regulação financeira dando ensejo aos abusos para escapar da legislação nacional de toda sorte ${ }^{31}$.

Um reflexo contundente na área jurídica é, sem dúvida, a possibilidade de harmonização normativa que abrisse caminho a essa intensificação das trocas internacionais, mas também como fruto do que VOGEL afirmou acima, do processo de construção de uma ética mundial. Mas é próprio também do capitalismo, para Boaventura de Sousa SANTOS, a globalização das lutas que tornem possível a distribuição democrática da riqueza, assente em direitos de cidadania, individuais e coletivos, aplicados transnacionalmente ${ }^{32}$. Em outra perspectiva, FERRAJOLI vislumbra que o impacto da globalização nas novas formas de

\footnotetext{
${ }^{28}$ IANNI, Octavio. A Era do Globalismo, op.cit., p. 11.

${ }^{29}$ FOLKER, Froebel (et al.), The New International Division of Labor. Cambridge: Cambridge University Press, 1980.

${ }^{30}$ CASTELLS, Manuel. The Information Age: Economy, Society and Culture, vol. I: The Rise of Network Society, Oxford, 1996, p. 92.

${ }^{31}$ Especificamente, fazemos referência aos recentes escândalos envolvendo o Banco HSBC na Suíça por fraude fiscal e por ter sido negligente (a ser apurado) em reportar operações suspeitas (V., entre outros: "Ao divulgar queda de lucro, presidente do HSBC diz que práticas na Suíça eram vergonhosas", disponível em: http://veja.abril.com.br/noticia/economia/ao-divulgar-queda-de-lucro-presidente-do-hsbc-diz-que-praticasna-suica-eram-vergonhosas, Acesso 21.02.2015).

${ }^{32}$ SANTOS, Boaventura Sousa. A Globalização e as Ciências Sociais, São Paulo: Ed. Cortez, 2002, p. 71.
} 
criminalidade é efeito da situação geral de anomia, em suas palavras, "em um mundo cada vez mais integrado e interdependente e confiado à lei selvagem do mais forte: um mundo atravessado por desigualdades crescentes (...)"33. Essa interdependência também pressupõe, cada vez em maior medida, que a proteção dos bens jurídicos de cada um dependa da realização de condutas positivas (de controle de riscos) por parte de terceiros, aumentado a necessidade de transferências de funções de segurança nas esferas alheias ${ }^{34}$.

Uma resposta adequada às mudanças por que passa a questão criminal deveria ser uma mudança de paradigmas do direito penal à altura dos novos desafios trazidos pela globalização, no entendimento de FERRAJOLI ${ }^{35}$. Essa mudança de paradigma é captada tanto pela perspectiva dos direitos humanos, internacionalização e expansão do direito penal e expansão, inspirados na cosmovisão anunciada por BOBBIO que alerta para os riscos de perdas democráticas: "melhor uma liberdade sempre em perigo mas expansiva do que uma liberdade protegida e incapaz de desenvolver-se. Somente uma liberdade em perigo é capaz de renovar-se. Uma liberdade incapaz de se renovar se transforma cedo ou tarde numa nova escravidão" ${ }^{\text {36 }}$. Talvez uma leitura moderna da frase de Benjamin Franklin inscrita na Estátua da Liberdade: “Aqueles que podem abrir mão da liberdade essencial para obter um pouco de segurança não merecem nem liberdade nem segurança"37.

\subsubsection{Constelação de riscos e crise do direito penal}

Para entendermos a harmonização normativa que incide sobre o direito penal, devemos antes compreender os fatores de desarmonia, sendo um dos principais a própria percepção dos riscos, na construção do que BECK chamou de sociedade do risco. Nunca uma sociedade viveu numa época tão segura, mas ao mesmo tempo nunca essa mesma sociedade sentiu-se tão ameaçada: catástrofes naturais, como terremotos e tsunamis, acidentes nucleares, guerras, fome, ataques terroristas, crises financeiras. Sem dúvida que a

\footnotetext{
${ }^{33}$ FERRAJOLI, Luigi. “Criminalidad y globalización” (trad. Miguel Carbonell), 2008, p. 17, disponível em www.cienciaspenales.net (Acesso 30.7.2014).

${ }^{34}$ Modelo típico adotado para prevenção do crime de lavagem de dinheiro.

${ }^{35}$ FERRAJOLI, Luigi. "Criminalidad y globalización”, op. cit., p. 22.

${ }^{36}$ BOBBIO, Norberto. El tiempo de los derechos (Trad. Rafael de Así Roig), Madri: Ed. Sistema, 1991, p. 254.

${ }^{37}$ Do original: "They that can give up essential liberty to obtain a little safety, deserve neither liberty nor safety”.
} 
potência das armas aumentou, sobretudo com a possibilidade de ataques por aviões não tripulados sem risco ao país que ataca, mas somente ao país atacado, e assim a sensação do medo aumenta com a mitificação que essa ferramenta, o medo, exerce no imaginário repetidas vezes pelas televisões, que também alardeiam a nova epidemia. Por outro lado, as instâncias internacionais também estão mais prontas para agir e condenar violações no âmbito das relações internacionais, em vista das ameaças à estabilidade política causada, pelo menos, por um Estado.

A "irresponsabilidade organizada" da sociedade de risco deixa-a incapaz de agir de forma política dissuasória, sobretudo em face dos novos riscos, inclusive a possibilidade de autoaniquilamento, dentro de uma "comunidade de perigo mundial", forjando uma unidade artificial que em âmbito internacional pudesse dar conta destes novos riscos. Por irresponsabilidade organizada o autor se refere a forma como as instituições da sociedade moderna admitiram o surgimento dos riscos de catástrofe enquanto simultaneamente negam a sua existência, esconderam suas origens e impediram a compensação e o controle ${ }^{38}$, como numa sociedade governada por um simulacro, num diálogo friamente calculado com a opinião pública. BECK descreve a tradução da criação e percepção do medo em ação política transformadora: de que forma as ameaças permanentes a que a sociedade está submetida conforma a vida ao nível dos cidadãos, fazendo com que a segurança assuma o lugar da liberdade $^{39}$, elevando o risco à categoria de paradigma explicativo da sociedade contemporânea? ${ }^{40} \mathrm{O}$ ideal de uma sociedade com liberdade dá lugar ao de uma sociedade em que se desfrute de segurança, retomando a ideia da pirâmide de Maslow, o que acaba por justificar as maiores transferências de poderes, aceitando-se qualquer antecipação de perigo, até o ponto de a preocupação com a aparição do acidentes ficar maior do que com eles próprios, pois a ação preventiva integra todos os mantras da vida moderna.

O pressuposto, assim, é de, ao incorporar o perigo como meio natural no desenvolvimento de nossa vida cotidiana, toda política criminal deverá considerar o risco em sua elaboração. Na tentativa de controlar os riscos, as sociedades procurarão decifrar uma lógica de produção, distribuição e contenção. BECK diferencia entre riscos aceitáveis,

\footnotetext{
${ }^{38}$ MACHADO, Marta R. A. Sociedade do risco e direito penal. Uma avaliação de novas tendências políticocriminais. São Paulo: IBCCRIM, 2005, p.61.

${ }^{39}$ BECK, Urich. La sociedad del riesgo mundial, Barcelona: Paidós, 2008, p. 26 ss.

${ }^{40}$ BERDUGO GÓMEZ DE LA TORRE, I.; PÉREZ CEPEDA, A. "Derechos Humanos y Derecho Penal. Validez de las viejas respuestas frente a las nuevas cuestiones". Revista Penal, nº. 26, julho/2010, p. 89.
} 
diante das oportunidades verificáveis, e riscos inaceitáveis, mas criticamente pondera que um risco inaceitável não depende de questões objetivas, mas de opções políticas e alinhamento estratégico de prioridade. Nesse sentido, a opção norte-americana de liderar o combate internacional ao mercado de drogas e crimes ligados à corrupção de agentes públicos, ao lado de seu pouco entusiasmo em relação à jurisdição do Tribunal Penal Internacional ou às iniciativas globais na área do meio-ambiente. Diante disso, não cabe outra alternativa ao Estado, que não distingue mais entre um perigo real, uma ameaça ou o risco, do que organizar sua forma de reagir por meio da prevenção, como a atitude correta a ser empreendida, e passando e incorporar o risco como elemento de relevância penal com natureza e reflexo normativos. Isto porque a encenação do risco torna-o mais real do que ele precisa ser para que a ação política de fato ocorra.

O risco aceito, socialmente adequado e que deve contribuir para o desenvolvimento social, tecnológico e científico tem sido incorporado com exagero, causando a transformação do princípio da intervenção mínima em intervenção máxima, "visto que também se tutelam novos interesses e funções, ou seja, instituições, modelos ou objetivos de organização política, social ou econômica, ou ainda contextos, entornos, ou condições de fruição dos bens jurídicos individuais, deixando de lado o critério limitador do bem jurídico, o que se encontra em clara contradição com o princípio da lesividade" ${ }^{41}$. $\mathrm{O}$ discurso torna-se facilmente o do "populismo antigarantista", no qual as garantias fundamentais são facilmente reduzidas a um mínimo em prol da eficiência do poder repressivo do Estado de Direito com o fim declarado ou não de acalmar a opinião pública e sua ideia ancestral de vingança ${ }^{42}$.

O resultado é um Estado impotente diante dos novos riscos, uma ordem mundial disfuncional diante desses mesmos riscos, que quer garantir a segurança sem conseguir oferecer bem-estar, em uma sociedade que consome o risco, como um produto trabalhado pelos mass media e que de maneira equivocada provoca o direito penal para que funcione em torno do risco, erija o direito penal como o instrumento para que o Estado atinja esse objetivo. Essa situação está atrelada a uma crise do direito diante da globalização,

\footnotetext{
${ }^{41}$ BERDUGO GÓMEZ DE LA TORRE, I.; PÉREZ CEPEDA, A. “Derechos Humanos y Derecho Penal (...)”, op. cit., p. 90 (trad. livre).

${ }^{42}$ Isso porque tem sido demonstrado em pesquisas criminológicas que o endurecimento das penas não reduz os índices de criminalidade, e da mesma maneira, não garante a maior segurança das pessoas". MAQUEDA ABREU, Maria Luísa. "Crítica a la reforma penal anunciada", JpD, n 47, 2003, p. 87.
} 
incapaz de atribuir alguma organicidade a um emaranhado disperso de convenções, tratados, legislações e que pouco conseguiu em termos efetivos de redução das desigualdades ou do ciclo de pobreza ${ }^{43}$. Assim, para FERRAJOLI, a globalização seria um vazio de direito público à altura dos novos poderes e dos novos problemas, como a ausência de esfera pública internacional, ou seja, de um direito e um sistema de garantias e instituições idôneas para disciplinar os novos poderes desregulados e selvagens tanto do mercado como da política ${ }^{44}$. Em sentido semelhante, a aceitação das consequências da globalização para o direito penal como natural, limitaria a função dos teóricos a pouco mais do que aceitar a existência destas manifestações delitivas e tentar articular políticas criminais adequadas, adotando-se como fundamentais os bens jurídicos que interessam à expansão do mercado ${ }^{45}$, conforme ironicamente nos expõe TERRADILLOS BASOCO.

A funcionalização do direito penal em direção à proteção a valores e mecanismos econômicos, especialmente incentivado pela globalização, desnatura o próprio princípio da lesividade, e a função garantista do bem jurídico penal, pois ao criar novos bens, com características multiforme e contornos difusos, nas palavras de TERRADILLOS BASOCO, não poderia erigir-se como critério definidor nem limitador do poder punitivo ${ }^{46}$. Como vimos, a globalização dirige o sistema penal a "demandas fundamentalmente práticas, no sentido de uma abordagem mais eficaz da criminalidade", ao se prescindir das garantias e estribar-se no que convenientemente passou-se a chamar de "legislação excepcional ${ }^{47 "}$ ". A crise de superprodução de normas de direito penal causa, em última instância, o colapso de sua capacidade regulatória, a banalização do mal que a prevenção geral negativa da norma pode causar, produzindo o seguinte retrato: caos normativo, multiplicação das fontes, superposição de competências, cujas incertezas ${ }^{48}$ e arbitrariedades podem levar o direito atual a se aproximar do direito jurisprudencial pré-moderno, como denunciando FERRAJOLI, no qual o aparente paradoxo que a inflação legislativa também leva a ausência

\footnotetext{
${ }^{43}$ Em igual sentido, MENEZES, Wagner. Tribunais internacionais - jurisdição e competência. São Paulo: Ed. Saraiva, 2013, p. 91.

${ }^{44}$ FERRAJOLI, Luigi. “Criminalidad y globalización”, op. cit., p. 18.

${ }^{45}$ TERRADILLOS BASOCO, "El derecho penal de la globalización: luces y sombras”, op. cit., p. 187.

${ }^{46}$ TERRADILLOS BASOCO, "El derecho penal de la globalización: luces y sombras”, op. cit., p. 189.

${ }^{47}$ SILVA SÁNCHEZ, Jesús-María. A expansão do direito penal (...), p. 66 e 86-88.

${ }^{48}$ Para CHOULIARAS, Athanasios, a globalização exacerbou ainda mais a dificuldade de apreensão dos exatos contornos do fenômeno criminal pelo direito, favorecendo a ocorrência de novas formas de criminalização e justiça criminal. "Bridging the Gap between Criminological Theory and Penal Theory within the International Criminal System”. European Journal of Crime, Criminal Law and Criminal Justice 22, 2014, p. 250.
} 
de regras, limites e controles sobre os grandes poderes econômicos transnacionais e sobre os poderes políticos que os alimentam.

Ressalta-se, assim, que a globalização é um terreno fértil para o avanço de um direito penal expansivo, de novas categorias, mas que paradoxalmente, encontra um Estado mais fraco para a mesma persecução. O resultado é um ambiente criminal mais regulado, mas também de um controle menos efetivo, que expõe a fragilidade do próprio direito ao manejar as categorias próprias de sua produção: a norma e o poder ${ }^{49}$. Ao atribuir ao direito penal o papel de resolver os problemas da sociedade mundial, de um direito penal máximo, garantindo a utopia da segurança, ao invés de ser um direito de ultima ratio, sobressai a impotência do direito que se impõe a despeito de suas funções de garantias e de prevenção, quebrando a confiança nas instituições do Estado, e, portanto, em crise, distanciando-se de seus princípios clássicos de legitimação, como a taxatividade, legalidade, ofensividade, proporcionalidade, obrigatoriedade da ação penal, e do papel do processo como instrumento de verificação dos fatos $\operatorname{cometidos}^{50}$ (contrariamente à criminalização preventiva). É geral a preocupação de que se atribua ao direito penal aquilo que ele puder resolver, ou tentar conter, evitando o mau uso do poder com a apresentação de respostas simbólicas para problemas reais, ou criando exigências exageradas que irão corroer as engrenagens do sistema penal ${ }^{51}$.

O recurso ao direito penal para a solução dos problemas da modernidade é temerário, porque ele é uma arma potente contra um alvo difuso, uma arma do Estado e em relação ao qual respondem os critérios democráticos e de legitimidade que qualquer exercício do poder do Estado requer. O direito penal é o pior candidato a solucionar os problemas da sociedade de risco, nas palavras de PRITTWITZ, isto porque o fato do direito penal ocorre no passado e o direito penal, portanto, orienta-se na busca de responsabilidades por fatos que ocorreram no passado. As sentenças em direito penal tampouco geram um comportamento no futuro, sendo o único ramo do direito que isso ocorre. Assim, ele não

\footnotetext{
${ }^{49}$ Em referência ao pensamento de DELMAS-MARTY, M., presente na obra "Lo relativo y lo universal Estudios jurídicos comparativos e internacionalización del Derecho", (trad. Marta M. Morales Romero). Instituto de Derecho Penal Europeo e Internacional. Universidad Castilla-La Mancha, disponível em http://www.college-de-france.fr/media/mireille-delmas-marty/UPL12997_ UPL2491_rescoursespdm0203. pdf (Acesso 10.11.2014).

${ }^{50}$ FERRAJOLI, "La democracia constitucional", op. cit., p. 24.

${ }^{51}$ PRITTWITZ, Cornelius. "A função do direito penal na sociedade globalizada do risco - defesa de um papel necessariamente modesto”. In: AMBOS, Kai; BÖHN, María Laura (coords.). Desenvolvimentos atuais das ciências criminais na Alemanha. Gazeta Jurídica: Brasília, 2013, p. 58.
} 
modula ações e reações no plano fático. Um segundo motivo é o fato de o direito penal funcionar dentro de respostas binárias, em um programa normativo limitado apenas para dizer "sim" ou "não", afirmando a existência ou não de culpabilidade. Os problemas da sociedade de risco não se resolvem apenas dentro desse binômio, requerendo criatividade, negociação e ponderação. Em terceiro, o direito penal clássico foi orientado ao indivíduo, ao passo que a sociedade de risco não tem o indivíduo como objeto a ser combatido primariamente - os riscos nesta escala são criados por coletividades criminosas, empresariais, até estatais ou internacionais. $\mathrm{O}$ autor ainda nos brinda com outra trinca de motivos pelos quais o direito penal não serve para conferir maior proteção numa sociedade do risco. O direito penal reage ao comportamento individual desviado, já a sociedade do risco se preocupa com as causas sistêmicas dos problemas causados às funcionalidades e atividades do Estado. A individualização do problema, por meio de um comportamento desviado, enfraquece a forma de enfrentar o problema, portanto. Referindo-se aos riscos ambientais, o autor indica que $90 \%$ dos danos ao meio ambiente são resultados de atividades absolutamente legais, ou seja, realizando riscos permitidos, no que representa uma barreira à atuação do direito penal.

Também não serve o direito penal para enfrentar os problemas da sociedade de risco pois as consequências que o direito penal prescreve visam atribuir penas aflitivas aos mesmos indivíduos fora do campo de prevenção da sociedade de risco. Assim, as consequências jurídicas dramáticas e invasivas, por meio das penas restritivas de liberdade, penas capitais (em alguns países), restritivas de direito, funcionam mal como um remédio aos problemas geralmente atribuídos a entes despersonificados. Por fim, o direito penal separa o "bom" do "mau", o que, para a sociedade do risco, designar-se de "mau" não fornece o tratamento adequado àquilo que causa o perigo. A significação do perigoso como mau não dá as respostas que indicam o tratamento correto para a redução ou contenção do problema, mas apenas estigmatiza o causador, conduzindo a uma ruptura ao invés de abrir caminho para a ressocialização ou ajustamento de conduta de acordo com os padrões aceitos.

Para que o direito penal sirva à globalização, para VIADA ${ }^{52}$, deveríamos viver num mundo com menores desigualdades sociais e pauperização dos países menos desenvolvidos, com a construção de um direito penal de mínimos, com novos tipos, mas

${ }^{52}$ Viada, Natacha G. Derecho penal y globalización..., op. cit, p. 46. 
limitando aqueles que poderiam ser solucionados com penas alternativas, com fortalecimento das condições para a cooperação internacional, com avanços na harmonização processual e substantiva em matéria penal até um pluralismo ordenado, defendido por DELMAS-MARTY ${ }^{53}$, além da criação de órgãos de justiça supranacional para proteção dos direitos humanos. Correndo o risco de construir um sistema jurídico que mantenha os mesmos graus de desigualdade que a desigualdade econômica, pode-se estar caminhando para reunir sob o mesmo sistema jurídico clássico (civilista ou de common law) com base numa aproximação em termos de política criminal e de segurança que abranja todos os países, que levasse a uma numa pretensa legitimação para que os países desenvolvidos produzam o direito, realizem os julgamentos e condenem os atos praticados nos países subdesenvolvidos, num uso político ${ }^{54}$ dos instrumentos internacionais.

BERDUGO e PÉREZ, por sua vez, defendem que o direito penal do futuro trilhe o mesmo traçado do velho direito penal, mas adaptado às necessidades de um presente sempre em mutação, colaborando com a construção de um direito penal como ferramenta útil para a tutela dos direitos humanos em todo o mundo e garantir, por esta via, a "liberdade individual de todas as pessoas, mas também deve tender a uma ampla humanização, no sentido de um direito penal, ao mesmo tempo liberal e social, que comporte uma atenuação geral da repressão" ${ }^{\circ 5}$.

\subsection{Criminalidade no cenário global}

\subsubsection{Crimes globais e enfrentamentos internacionais}

A intensificação das trocas internacionais aliadas às facilidades propiciadas pela tecnologia, transporte e informação, ainda que de maneira moderada, alterou a realidade da criminalidade, mas sem que tenha gerado em si uma criminalidade global, apesar dos

\footnotetext{
${ }^{53}$ DELMAS-MARTY, M. (trad. Marta M. Morales Romero), "Un pluralismo ordenado - Estudios jurídicos comparativos e internacionalización del derecho", op. cit., p. 14.

${ }^{54}$ Sobre o uso político dos direitos humanos, IGNATIEFF, Michel. Los derechos humanos como política e idolatría. Barcelona: Paidós Estado y Sociedad 108, 2003.

${ }^{55}$ BERDUGO GÓMEZ DE LA TORRE, I.; PÉREZ CEPEDA, A. "Derechos Humanos y Derecho Penal...", op. cit., p. 100 (trad.livre).
} 
sensíveis efeitos criminológicos. $\mathrm{O}$ fato de um crime transitar e transpor fronteiras modula a criminalidade transnacional $^{56}$, e isso pode ter encontrado na globalização um fator que favoreça esse tipo de crime $^{57}$. Assim, a ocorrência de crimes relacionados à atividade econômica é potencializada, assim como a criminalidade em relação ao controle aduaneiro, exigindo uma regulação global de temas como a corrupção de funcionários públicos estrangeiros, crimes contra a propriedade intelectual, crimes por meio da internet, tráfico de pessoas. É comum os crimes aproveitarem-se das oportunidades oferecidas com a abertura de caminho propiciada pelas novas correntes econômicas, novas formas de capitalismo e de organizações capitalistas, até porque as oportunidades econômicas chamam a atenção para a riqueza que criam e pelo meio de que se valem.

Abrindo o campo internacional para a evolução do direito penal, por meio dos crimes internacionais, contribui-se para o processo de globalização do direito penal, pressupondo questionamentos de ordem axiológica, por estarmos projetando em escala universal a parte mais simbólica do direito, "aquela que expressa pelo jogo dos ilícitos fundamentais uma identidade comum, a do pertencimento à sua comunidade de valores", num universalismo normativo, ainda que fragilmente encontrado no plano empírico, conforme DELMAS-MARTY ${ }^{58}$, mas que confirma o pensamento de BORDIEU de que "os símbolos são instrumentos por excelência da integração social" ${ }^{\text {59 }}$. A preocupação em relação ao uso simbólico do direito penal infelizmente é que não se atinge, por meio dele, a função primordial de efetivamente comunicar e fazer vigorar os valores de uma comunidade internacional segura e livre dos crimes mais violentos, vivida em paz e em harmonia ${ }^{60}$, por

\footnotetext{
56 Para CANCIO MELIÁ, Manuel, esse seria o grande vetor para a internacionalização do direito penal, "Internacionalización del Derecho Penal...", p. 227.

${ }^{57}$ VOGEL, Joachim. "Derecho Penal y Globalización”, op. cit., pp. 115-6.

58 DELMAS-MARTY, Mireille; CASSESE, Antonio. Crimes internacionais e jurisdições internacionais. Barueri: Ed. Manole, 2004, p. xvii. Também SALVADOR NETTO, Alamiro Velludo, Finalidades da Pena, Conceito Material de Delito e Sistema Penal Integral, Tese de Doutorado, FADUSP, 2008, p. 5, sobre a expansão do conceito de delito para campos tradicionalmente não penais.

59 BOURDIEU, Pierre. O poder simbólico. (Trad. Fernando Tomaz). $4^{\mathrm{a}}$ ed., Rio de Janeiro: Bertrand Brasil, 2001 , p. 10.

${ }^{60}$ A respeito do uso simbólico do direito penal, v. JAKOBS, Günther; CANCIÓ MELIÁ, Manuel. Derecho Penal del Enemigo. Madri: Civitas. 2003, p. 217, ou cf. HASSEMER, W., ressaltando a prevalência de "uma oposição entre realidade e aparência (...) entre o "verdadeiramente querido' e o "diversamente aplicado", "La autocomprensión de la ciencia del derecho penal frente a las exigencias de su tiempo" (Trad. María del Mar Diaz Pita). In: MUÑOZ CONDE, Francisco (Coord.). La ciencia del derecho penal ante el nuevo milenio. Valência: Tirant lo Blanch, 2004, p. 28.
} 
características típicas destes crimes, como o contexto organizacional da prática e as deficiências da função preventiva nesses $\operatorname{casos}^{61}$.

Essa avaliação também é compartilhada por SILVA SÁNCHEZ ${ }^{62}$, quando observa que a expansão do direito penal decorre de uma espécie de perversidade do aparato estatal, e mesmo no âmbito internacional, da ação atribuída a cada Estado na construção dos institutos de direito internacional, ao buscar na legislação penal a solução de todos os problemas sociais, com o deslocamento do foco para o plano simbólico. Como resultado desta ação, afirma o autor, resulta que "as instituições do Estado não somente acolham tais demandas irracionais sem qualquer reflexão, em vez de introduzir elementos de racionalização nas mesmas", alimentando-as em termos populistas. O sistema penal, além de mais extenso e cruel, nas palavras de SALVADOR NETTO ${ }^{63}$, torna-se mais impaciente em vista da desenfreada antecipação de tutela, tipificações de perigo abstrato e mera conduta, num "desespero protecionista".

Os casos de violações graves de direitos humanos ou de infrações ao direito internacional humanitário são problemas tratados como da comunidade mundial, ainda que VOGEL alerte para o risco de que problemas que não sejam realmente globais, como a escravidão e a pirataria, a criminalidade relacionada às drogas, terrorismo internacional, a partir da vinculação a que se trate de "ataques à civilização" ou aos "interesses comuns de todos os povos civilizados" ${ }^{\$ 4}$. Junto com o incremento da criminalidade ${ }^{65}$, próprio do mundo contemporâneo, nota-se também uma criminalidade nova, potencializada por uma forma de organização mais profissionalizada, uma integração em formato de rede que se organiza ao redor do mundo (p. ex., ligada ao tráfico de drogas), o tráfico de seres humanos, criminalidade econômica ${ }^{66}$, marcados essencialmente pelo excesso de inteligência, mas também pela capacidade de dano.

\footnotetext{
${ }^{61}$ Tema a ser aprofundado no capítulo IV da tese.

${ }^{62}$ SILVA SÁNCHEZ, Jesús-María. La expansión del derecho penal..., op. cit., p 23.

${ }^{63}$ SALVADOR NETTO, Alamiro Velludo. Finalidades da pena, conceito material do delito (...), op. cit., p. 6.

${ }^{64}$ VOGEL, Joachim, op. cit., p. 116.

${ }^{65}$ Afirma-se que os tempos atuais assistem o incremento da criminalidade, conforme entende o Conselho Científico Criminológico do Conselho da Europa. V. SHAW, Mark; VAN DIJK, Fan; RHOMBERG, Wolfgang. "Determining trends in global crime and justice: an overview of results from the united nations surveys of crime trends and operations of criminal justice systems. Disponível em http://www.unodc.org /pdf/crime/forum/forum3 Art2.pdf (Acesso 30.08.2014).

${ }^{66}$ V. ARROYO ZAPATERO, Luís. "A harmonização internacional do Direito Penal: ideias e processos" in RIBCCRIM, ano 18, n 84, maio-jun/2010, pp. 62-64.
} 
Fato é que cada vez mais a globalização é vista como um potencializador de uma criminalidade especial, chamada por alguns de criminalidade globalizada, marcando uma nova agenda para o direito penal, que se depara com a crença de que "frente a internacionalização do crime, urge responder com a internacionalização da política de combate ao crime" ${ }^{\prime 67}$. Nesse sentido, reforçam-se as ações de integração para a luta, cooperação internacional e intercâmbios de conhecimentos e de ações de polícia. Reflexão aprofundada merecem as palavras do Ministro federal do interior alemão: "na luta contra o terrorismo temos que fazer uso efetivo de todos os instrumentos que estão à disposição do terrorismo. O direito penal é parte de uma missão de segurança do Estado de orientação preventiva. Temos que combater o terrorismo, também com o direito penal, ali onde comece a ser perigoso, e não somente quando se tenham produzido atentados" ${ }^{\circ 8}$, alterando-se fundamentalmente a atuação do Estado, com discurso preventivo ("quando comece a ser perigoso"), para uma política proativa (“e não somente quando se tenham produzido atentados), inclusive à margem do Estado de Direito ${ }^{69}$ ("com o uso efetivo de todos os instrumentos que estão à disposição do terrorismo”).

Os mecanismos de resposta a essa criminalidade global têm sido articulados de maneira conjugada, dentro do uso preventivo do direito penal, de persecução coordenada de agressões criminais e favorecendo a articulação das instituições que compõe o sistema de justiça criminal internacional, como forma de se forjar uma coesão intra-sistêmica ${ }^{70}$. Essa articulação em torno do combate internacionalizado do crime, por sua vez, segue um rito específico quando liderados por agências ou organismos internacionais. Inicialmente, aprovam-se programas globais de ação, buscando assumir a liderança na promoção e

\footnotetext{
${ }^{67}$ MIRANDA RODRIGUES, Anabela; LOPES DA MOTA, José Luís. Para uma política criminal europeia. Quadro e instrumentos da cooperação judiciária em matéria penal no espaço da União Europeia, Coimbra: Coimbra Editora, 2002, p. 15.

${ }^{68}$ SCHÄUBLE, Wolfgang. Zeitschrift für Rechtspolitik, 2006, p. 71, conforme citado por CANCIO MELIÁ, "La internacionalizacioón del derecho penal...", op. cit., p. 232.

${ }^{69}$ Em confronto exatamente com o já antecipado por RUDOLPHI: "si se quiere evitar que el Estado de Derecho sea vaciado y minado desde dentro por la lucha contra el terrorismo, ha de prestarse una estricta atención a que no se renuncie de ningún modo a los principios propios del Estado de Derecho. Hay que evitar que nuestro Estado de Derecho ni siquiera por aproximación se convierta en aquella imagen que los terroristas, desconociendo radicalmente la realidad, presentan ya ahora injuriosamente de él. Pues también esto en última instancia supondría el triunfo de los terroristas sobre el Estado de Derecho", RZP 1979, p. 214, citado por CANCIO MELIÁ, "Internacionalización del derecho penal...", p. 239.

${ }^{70}$ Conforme BASSIOUNI, M. Cherif. "International Criminal Justice in the Age of Globalization", International Criminal Law: Quo Vadis, AIDP, ${ }^{\circ}$ 19, 2004, p. 79, a respeito das instituições do Sistema de justiça internacional, e p. 90, sobre o progresso movido pelos atributos da globalização.
} 
coordenação de ações interestatais daquelas infrações consideradas de especial interesse de ocorrência ou impacto internacional. Os instrumentos aprovados pelas agencias ${ }^{71}$ privilegiam um enfoque puramente punitivo do fenômeno, e concentram-se na harmonização de definições e dos padrões de criminalização e no estabelecimento de bases firmes para a cooperação na investigação e persecução dos crimes, sendo que apenas de maneira residual refere-se a temas de prevenção criminológica dos crimes ou do tratamento dos delinquentes ${ }^{72}$.

Do que vimos até então, encontram-se na agenda da globalização para o direito penal os seguintes temas:
a) criminalidade empresarial
b) criminalidade econômica individual
c) criminalidade organizada (tráfico de pessoas, terrorismo, drogas)
d) criminalidade ambiental
e) criminalidade contra os valores da humanidade
f) política criminal

Cada um destes tópicos representa uma lógica e um interesse nacional e setorial por trás, com esforços políticos e teóricos próprios a lhes dar substrato. Ainda que representem reflexos do mesmo sentido expansivo da tutela penal na globalização, ensejam os mesmos desafios de: aumento de esforços de harmonização em matéria penal, intensificação das iniciativas voltadas à cooperação, flexibilização do princípio da territorialidade desencadeando um processo supranacional de integração jurídica (judicial e legislativa) ao que VOGEL chamou de interlegalidade.

Tratando desta criminalidade internacional, BASSIOUNI entende que crimes internacionais não são sinônimos de delitos internacionais. Para o autor, são crimes internacionais aqueles atos que afetam ou a paz e a segurança da humanidade, ou são contrários aos direitos humanos, ou resultado de uma ação política do Estado. Em

\footnotetext{
${ }^{71}$ Convenção das Nações Unidas contra o Tráfico Ilícito de Drogas e Substâncias Psicotrópicas de 1988, Convenção das Nações Unidas contra a Corrupção, 2005, com capítulo sobre prevenção, Convenção das Nações Unidas contra o Crime Organizado, 2000.

${ }^{72}$ CUESTA, José Luis de la, “Retos y perspectivas...”, op. cit., p. 280.
} 
consequência, são crimes típicos do direito penal internacional, quando se estuda sua competência. Por outro lado, delitos internacionais são aquelas infrações penais que afetam um interesse protegido pelo direito internacional, sem chegar à relevância e magnitude dos crimes internacionais, por outro, contém elementos de transnacionalidade. Assim, entre os delitos internacionais, BASSIOUNI ${ }^{73}$ enumera: pirataria, atentados à segurança da navegação aérea internacional, atentados à navegação marítima e das plataformas em altomar, infrações contra as pessoas protegidas internacionalmente, sequestro internacional, financiamento ao terrorismo, uso ilícito dos meios postais, criminalidade transnacional organizada, atentados contra o meio ambiente, corrupção de funcionários públicos estrangeiros, tráfico de pessoas, entre outros.

Ocorre que em direito internacional penal, poucas vezes se declara claramente que um fato incriminado é um crime internacional. A contrário, o que ocorre comumente é os Tratados internacionais conterem prescrições dirigidas aos Estados parte com três principais mandamentos: a) obrigando-os a tipificar o fato em seu ordenamento interno; b) obrigando-os perseguir o fato punível, julgar e executar a pena; e b) atender a obrigação de extraditar aquelas pessoas acusadas ou declaradas culpadas pelo fato incriminado no tratado em outro Estado parte ${ }^{74}$. Organiza-se, assim, em torno de um tratado em matéria penal, uma comunidade de Estados que perseguem o mesmo fato, envolvidas que estão em torno do mesmo objetivo e critério de valores e que optaram pelo recurso à ação em conjunto e de conteúdo penal para criar um ambiente mais seguro à sua população.

\subsubsection{Tendências a respeito: internacionalização e interlegalidade}

Os efeitos da globalização para o direito penal são recepcionados de maneiras diversas. Em primeiro lugar, destacamos seu efeito multiplicador e condutor da expansão do direito penal, na construção teórica feita por SILVA SÁNCHEZ, que reduzirá seu aspecto garantista e menos próprio de um Estado de Direito, com regras de imputação mais flexíveis

${ }^{73}$ BASSIOUNI M. Cherrif. "El derecho penal internacional: historia, objeto y contenido". ADPCP Oceana Publications, Nova Iorque, p. 11.

${ }^{74}$ VIADA, Natacha G. Derecho penal y globalización., op. cit., p. 96. 
e relativizando as garantias processuais ${ }^{75}$. PRITTWITZ, por sua vez, identifica na globalização fenômeno que causa uma dolorosa erosão de nossa herança cultural comum, além do fato de que a globalização necessariamente conduza a adaptações e equiparações que levará à perda de peculiaridades das distintas tradições ${ }^{76}$ e referências de suas culturas jurídicas.

VOGEL reforça a existência de uma nova dinâmica, fruto da integração de maneira desordenada de diversos planos de legalidade ou normatividade, citando que "vivemos em um tempo de (...) redes de contato de ordens jurídicas que nos forçam em direção a constantes transições ou trespasse. Nossa vida jurídica é constituída pela (...) interlegalidade" 77 . Essa interlegalidade pressupõe a captação dos valores essenciais para a compreensão e posicionamento nesse contexto, não a condição estática de uma determinada ordem jurídica, mas essencialmente a "dinâmica do processo de intercâmbio entre as distintas ordens" ${ }^{\text {78 }}$. É da convergência da atuação de uma miríade de novos agentes, de novas relações, de novas ordenações e de novos interesses que faz com que interlegalidade seja considerada um fenômeno chave do direito penal da globalização. Notamos que esta interlegalidade, a demandar concertos internacionais para assinatura de determinada convenção internacional, também abrangendo a importância dos papéis desempenhados pelas organizações não-governamentais de alcance global, a influência exercida por Estados poderosos, como os Estados Unidos, na conformação das legislações penais de outros países $^{79}$.

O segundo elemento para a compreensão da globalização nas esferas jurídicas da interlegalidade é a existência de um objetivo comum que orienta a união dos diversos agentes: o fortalecimento da persecução penal e do interesse globalmente compartilhado nas punições, partindo da ideia de que os ordenamentos jurídicos nacionais são impotentes diante

\footnotetext{
${ }^{75}$ SILVA SÁNCHEZ, Jesús-María. La expansión del derecho penal..., op. cit., p. 21.

76 Por exemplo, a flexibilização do princípio da legalidade em direito penal internacional, ou as interinfluências do common law no direito civil praticado pelos tribunais internacionais. GIL GIL, Alicia. Derecho penal internacional. Madri: Tecnos, 1999 e BASSIOUI, M. Cherif, Introduction to International Criminal Law. 2 edicao, Brill:Nijhoff, 2012.

${ }^{77}$ Do original, "We live in a time of [...] network of legal order forcing us to constant transition or trespassing. Our legal life is constituted by [...] interlegality". VOGEL, op. cit., p. 117.

78 VOGEL, "Derecho Penal y Globalización", op. cit., p. 117. Contrariamente à existência atual de uma tendência de convergência científica, CANCIO MELIÁ, Manuel, "Internacionalización del Derecho Penal (...)”, pp. 226-7, afirmando que não se pode dizer que se tenha progredido muito em direção a um verdadeiro conhecimento mútuo.

${ }^{79}$ VOGEL, "Derecho Penal y Globalización”, op. cit., p. 118.
} 
da criminalidade transnacional. Também em relação a este aspecto, terá mais força o repertório de criminalidade elegida pelos poderes que organizem determinado concerto internacional. Passa a surgir a questão de a partir de quando se está diante de uma criminalidade global, ainda que de efeitos locais, ou de uma criminalidade transnacional. Por criminalidade global entende-se uma criminalidade gestada para ocorrer em diversas partes do globo simultaneamente, desestabilizadora e generalizada. Assim, crimes transnacionais corresponde a uma parte do conceito de crimes globais.

A interlegalidade, em relação ao direito penal, contribui como vetor de mudanças relevantes para a modernização do direito. Consoante observado por VOGEL, o direito penal passa a não desfrutar daquele status especial que confere à pena e o direito penal a ultima ratio da intervenção estatal, passando a ser tanto a ciência quanto seu mais contundente elemento, a pena, mais um dos vários mecanismos de intervenção estatal, em equivalência com os demais instrumentos de que dispõe o Estado na definição de suas prioridades e construção de sua política.

O direito penal globalizado se concentra em campos modernos, com características modernas, no sentido da crítica formulada por HASSEMER, com o uso frequente de crimes de perigo e de organização, com estruturas de imputação distintas e provas mais fáceis que as do direito penal clássico, conforme referido por VOGEL, com a incriminação de condutas no campo anterior ou posterior a um dano concreto, como a falsificação de documentos ou lavagem de dinheiro. Para ARROYO ZAPATERO ${ }^{80}$, por sua vez, o direito penal moderno não é mais do que a aceitação do direito penal das modernas condições da vida social do tempo contemporâneo, a requerer novas formas e instrumentos de proteção dessas novas necessidades sociais - conquanto vaga a afirmação, em essência trata-se da máxima flexibilização do direito penal para apoiar o combate aos novos inimigos da sociedade. $\mathrm{O}$ autor pondera que qualquer novidade absorvida pelo direito penal é parte e consequência da mudança de panorama global do nosso mundo cultural, em alguns dos seus contornos jurídicos, sintetizado na sensação de cidadania do mundo.

80 ARROYO ZAPATERO, Luís. "A harmonização internacional do Direito Penal: ideias e processos", RIBCCRIM, ano 18, n 84, maio-jun/2010, pp. 64-71. Faz referência, em especial, aos "delitos imprudentes", como os delitos contra a segurança viária, a incriminação da "direção perigosa" e exasperação das penas em caso de morte ou lesão, inclusive pela combinação com a previsão das penas administrativas pelo sistema de pontos na carteira de motorista. 
Ocorre que o direito penal, ao exigir um alto nível de legitimação do controle do poder punitivo do Estado ${ }^{81}$, não pode descuidar dessa sua função maior para se concentrar apenas no poder criativo de tipos penais. A atuação das organizações internacionais ou supranacionais, como a União Europeia, ensejam relevantes questionamentos em suas atribuições relacionadas ao crime e ao direito penal diante do déficit democrático, pela falta do poder de controle da ação punitiva, em suas competências substanciais em matéria de legislação penal ou política criminal ${ }^{82}$. Ressalta-se, portanto, que esse aspecto pragmático de um direito mais preocupado com a luta preventiva efetiva e de orientação policial, não gera necessariamente uma preocupação com a justiça ou com a profundidade de um processo de internacionalização do direito penal ${ }^{83}$. A exigência prática que a sociedade leva ao direito penal traz um enunciado vazio, sem apontar o que se entende por criminalidade e quais as condutas em questão, pois os instrumentos que se quer manipular, com o aumento das sanções e a redução das garantias, concentram-se nos campos preventivos.

A aplicação do direito penal na perspectiva da sua internacionalização e interlegalidade passa a ser mais complicada, menos previsível e mais custosa em tempo, o que de modo evidente afeta o "princípio jurídico-penal da determinação e do mandamento processual penal da celeridade", cobrando um preço ainda mais alto de sua legitimação e segurança jurídica de seus preceitos ${ }^{84}$. VOGEL questiona se nos encontramos a caminho de uma ciência global do direito penal, que trabalhe ainda que utopicamente sobre um direito penal mundial, ou se a ciência penal continua enraizada à sua família do direito penal de origem, cultivando a identidade e a cultura jurídico-penal nacional e, sobretudo, defendendoa contra os embates da globalização. Opina que a ciência do direito penal esteja mudando e que deve mudar sob o influxo da globalização em um sentido triplo: da abertura metodológica, sua aproximação da prática de casos e das questões materiais (em oposição às questões da dogmática jurídica) - numa referência à construção de uma gramática própria

\footnotetext{
${ }^{81}$ Manuel CANCIO MELIÁ refere-se à função de bloqueio do direito penal e de elementos de sua configuração dentro de um ordenamento jurídico estatal, "Internacionalización del Derecho Penal y de la Política Criminal: algunas reflexiones sobre la Lucha Jurídico-Penal contra el Terrorismo", apresentadado nas III Jornadas Jurídicas Luso-Espanholas: Internacionalização do Direito no novo século (ad honorem Jorge de Figueiredo Dias), Univ. de Coimbra, Faculdade de Direito, 24.11.2006.

82 VOGEL, "Derecho Penal y Globalización", op. cit., p. 119.

${ }^{83}$ Para CANCIO MELIÁ, não se está tratando apenas da internacionalização do pragmatismo dos agentes estatais no plano da persecução penal, mas sobretudo da ideologia penal, das perspectivas da teoria da pena, da infiltração das novas concepções penais na política criminal prática dentro dos Estados, "Internacionalización del Derecho Penal...", op. cit., pp. 227 ss.

${ }^{84}$ VOGEL, "Derecho Penal y Globalización", op cit., p. 123.
} 
na qual todos os ordenamentos nacionais se encontrem, se reconheçam e se equivalham. Em terceiro, de dedicar-se menos a questões de dogmática penal, também passa a preocupar-se com a política criminal, fazendo perene o direito penal a uma razão democrática. Estas mudanças, dentro de um contexto maior, de perda de poder estatal, de profundas alterações dentro da estrutura do direito, de integração e interdependência cada vez maior e mais poderosa de instituições de soberania, sistemas, tradições e culturas jurídicas, coloca-nos todos diante da gênese de um novo ramo do direito ${ }^{85}$, a ser maior debatido e aprofundado pelas áreas de teoria e filosofia do direito. Fato é que se pode falar de quase 200 sistemas legais nacionais, além instituições internacionais com poder de adjudicação ou escritórios de investigação, "todos perseguindo o mesmo tipo de violações, aplicando mais ou menos as mesmas normas" $" 86$.

Apesar da mudança por que passa o direito penal, a existência de uma justiça penal globalizada ainda está longe de qualquer horizonte plausível, até porque são muitas as dificuldades de funcionamento com uma unidade real e operacional, não somente no âmbito interestatal, mas sobretudo no seio dos próprios sistemas nacionais, conforme DE LA CUESTA. Segundo o mesmo autor, as tendências de internacionalização e a emergência de um Tribunal Penal Internacional não são ainda acontecimentos com força suficiente para mudar as bases principais da ordem penal internacional, cujos fundamentos continuam sendo a Paz de Westfalia ${ }^{87}$.

Conforme já assinalado no item 1.1.1, tem-se localizado na globalização seu potencial de desestruturação das funções de garantias, a espinha dorsal do direito penal: prevenção dos crimes e prevenção das penas arbitrárias. Em termos de prevenção dos crimes, FERRAJOLI trata de uma nova forma de criminalidade que ataca os bens e direitos fundamentais de uma sociedade ao ameaçar de forma mais grave os direitos, a democracia, a paz, o futuro do planeta, a chamada criminalidade do poder $^{88}$ : o crime organizado, o crime econômico e o crime dos poderes públicos. Está-se falando, não da criminalidade individual,

${ }^{85}$ CANCIO MELIÁ, M. "Globalización y Derecho". Anuário de la Facultad de Derecho de la UAM, num. 9, 2005. Também, em outra perspectiva, reafirmando o atual direito penal internacional em suas bases comuns, BASSIOUNI, M. Cherif. "International Criminal Justice in the Age of Globalization", op. cit., pp 79-90.

${ }^{86}$ Conforme BASSIOUNI, M. Cherif. "International Criminal Justice in the Age of Globalization", op. cit., pp 80 (trad. livre).

${ }^{87}$ CUESTA, José Luís de la. "Retos y perspectivas del sistema penal en un mundo globalizado", op. cit., p. 275.

${ }^{88}$ FERRAJOLI, Luigi. La democracia constitucional, op. cit., p. 22. 
marginal, mas fortemente organizada, estratificada, com grande poder de destruição ou de causar sofrimento em larga escala. Em alguns casos, por sua ligação com o poder, essa criminalidade representa uma força desenfreada, de difícil persecução e que persiste à margem das leis e do Estado de Direito, com grande expectativa de impunidade e grande capacidade de intimidação, por vezes sequestrando o próprio Estado de suas funções.

Diante da tendência expansiva do direito penal moderno, aliada à flexibilização de regras de imputação e de garantias penais individuais e empresariais, especialmente presente na sociedade do risco, BERDUGO e PÉREZ identificam algumas características relevantes para os propósitos do presente estudo: “a) instrumentalização do direito penal; b) tendência de o direito penal moderno tornar-se inoperativo, seletivo e simbólico; c) excessiva antecipação da tutela penal (prevencionista); d) exasperação punitiva; e) desformalização (flexibilidade das garantais penais, processuais e de execução); f) prisionização (explosão carcerária); g) excepcional, mais severo e repressivo; h) premial (colaboração com a justiça)" ${ }^{\prime \prime 9}$.

Diante dessas considerações, a internacionalização do direito penal tem trazido perspectivas disruptivas em relação ao direito tradicional. Entretanto, não podemos fechar os ouvidos a esses desafios, escondendo-nos no estático plano do direito tradicional, mas aprofundar os questionamentos que precisam ser feitos para posicionar os marcos jurídicos nesse novo cenário.

\subsection{Conformação de um direito penal comum}

\subsubsection{Extraterritorialidade, direito penal e competências compartilhadas}

Com vistas ao aprofundamento de questões específicas relacionadas à internacionalização do direito penal, vislumbramos alguns temas de fundamental

${ }^{89}$ BERDUGO GÓMEZ DE LA TORRE, I.; PÉREZ CEPEDA, A. "Derechos Humanos y Derecho Penal (...)" op. cit., p. 99-100 (trad. livre). 
importância. $\mathrm{O}$ aspecto territorial é dos que mais chama a atenção na confrontação do direito penal com as novidades trazidas pela globalização, a ponto de se chegar a dizer que o

\begin{abstract}
"direito penal parece ser irremediavelmente incompatível com a ideia de globalização (...), tradicionalmente considerado como manifestação genuína da soberania estatal, este ramo do ordenamento não se adapta com facilidade à tendência expansiva, e portanto, superadora de fronteiras, que parece constituir o ponto crucial da dinâmica econômica que se encontra na base do processo de mundialização" $"$.
\end{abstract}

Os diversos fatores jurídicos ensejados e incentivados pela globalização dependem da conjunção de distintas competências legislativas, executivas, incluindo regulamentares, e judiciárias. DELMAS-MARTY identificou essa sobreposição como uma descontinuidade, que pode ser tanto horizontal, em relação a organizações internacionais com atuações especializadas, como vertical, no momento em que estas passam do âmbito nacional ao internacional. O problema que se coloca é a existência de campos normativos que não são nem hierarquizados nem completamente autônomos ${ }^{91}$, sobretudo se associado à aplicação do princípio da ubiquidade para determinação do local da infração. Pelo princípio da ubiquidade afirma-se que o delito ocorreu tanto no tempo e local em que se praticou a ação, ainda que parcialmente, quanto onde se produziu o resultado ${ }^{92}$, tendência que vem ganhando adeptos como forma de o Estado estender sua jurisdição para além de suas fronteiras.

Recordamos que o princípio da territorialidade, presente tanto para o direito penal quanto internacional, foi originalmente concebido como um limite ao estabelecimento de normas de um Estado em relação ao outro. Ao reconhecer essa como uma característica da lei nacional, o Tribunal Permanente de Justiça Internacional, em 1927, sobre o assunto Lotus, afirmou que a primeira limitação em direito internacional aos Estados é que, na ausência de uma regra permissiva em contrário, um Estado não pode exercer de nenhuma forma seu poder no território de outro Estado. A jurisdição é, nesse diapasão, certamente territorial; ela não pode ser exercida por um Estado fora de seu território, "exceto em virtude

\footnotetext{
${ }^{90}$ TERRADILLOS BASOCO, J. M., "El derecho penal de la globalización: luces y sombras”, In: CAPELLA HERNÁNDEZ, Transformaciones del derecho en la mundialización, , op. cit, p. 185 (trad. livre).

${ }^{91}$ Como a relação entre jurisdição nacional e tribunais internacionais ou cortes internacionais de direitos humanos.

92 JIMÉNEZ DE ASUA, Luís. Tratado de derecho penal, t. II, Buenos Aires: Losada, 1957, p. 16.
} 
de uma regra permissiva derivada do costume internacional ou de uma convenção". Esse é o sentido do art. $5^{\circ}$ do Código Penal Brasileiro, guardando as opções de extraterritorialidade para casos especiais, como aqueles que o Brasil se comprometeu por tratado ou convenção a reprimir $\left(\operatorname{art.} 6^{\circ}\right)$, de genocídio quando o agente for brasileiro, entre outros. Interessante apontar que a mesma sentença do Caso Lotus, em relação aos apontamentos sobre o princípio da territorialidade, conclui que "não se afirma, entretanto, que o direito internacional proíba aos Estados de exercer sua jurisdição em seu próprio território com relação a qualquer situação relacionada com fatos que ocorram no exterior", deixando aberto o espaço para o exercício da competência extraterritorial.

Fato é que é crescente a aplicação extraterritorial do direito penal nacional, com a superposição de diversos direitos de punir levando ao forum shopping também na área penal, com a ocorrência maior de conflitos positivos de competência ou de jurisdição, com implicação no princípio do ne bis in idem. Um exemplo dessa aplicação extraterritorial cada vez mais alargada é a sua previsão na legislação norta-americana sobre corrupção de funcionários públicos estrangeiros, o Foreing Corrupt Practices Act, mas também da própria convenção da OCDE (“Convenção sobre o Combate da Corrupção de Funcionários Públicos Estrangeiros em Transações Comerciais Internacionais"93). Segundo essa convenção:

Cada Parte deverá tomar todas as medidas necessárias ao estabelecimento de que, segundo suas leis, é delito criminal qualquer pessoa intencionalmente oferecer, prometer ou dar qualquer vantagem pecuniária indevida ou de outra natureza, seja diretamente ou por intermediários, a um funcionário público estrangeiro, para esse funcionário ou para terceiros, causando a ação ou a omissão do funcionário no desempenho de suas funções oficiais, com a finalidade de realizar ou dificultar transações ou obter outra vantagem ilícita na condução de negócios internacionais (grifo nosso).

Nota-se que se trata de uma hipótese de aplicação extraterritorial da legislação brasileira para além do previsto no art. $7^{\circ}$ do Código Penal, inovando, por meio de convenção internacional, as hipóteses de abarcamento do fato ocorrido no exterior pelo direito brasileiro. Esta convenção tem motivado adaptações das legislações nacionais a se

${ }^{93}$ Aprovada pelo Congresso Nacional brasileiro por meio do Decreto Legislativo ${ }^{\circ} 125$, de 14 de junho de 2000. 
conformarem à previsão normativa internacional, como ocorreu com a alteração do Código Penal brasileiro para a inclusão do Capítulo II-A ao Título XI, que trata dos crimes praticados por particular contra a administração pública estrangeira ${ }^{94}$.

Apesar dessa expansão, pelos próprios instrumentos internos (normativas nacionais), ainda não se pode dizer que existe um direito penal supranacional, sobretudo quando olhamos para a União Europeia, com estruturas, coordenações e âmbito de cooperação muito mais alinhadas do que nos demais blocos de países do mundo. Entretanto, ainda que se diga que o direito penal da União Europeia se aproxime mais do direito penal internacional do que de um direito integrado, nota-se uma diferença fundamental: ele não está projetado para se limitar somente às funções de cooperação horizontal entre os Estados. Muito ao contrário, ele tem contornos próprios (e expansivos): facilitar uma cooperação horizontal entre os Estados membros reforçada pelo reconhecimento e pela confiança mútua, propiciar além disso uma cooperação vertical entre os Estados membros e a União Europeia, harmonizar o direito penal dos Estados membro (material e processual) e servir de instrumento de proteção dos interesses da União Europeia ${ }^{95 .}$ Apesar disso, por enquanto trata-se mais de uma influência comunitária poderosa nos ordenamentos nacionais, pois as faculdades sancionadoras diretas da União Europeia não ultrapassam o âmbito administrativo, ainda que sem dúvida represente uma importante experiência de compartilhamento de valores e práticas, inclusive no campo penal, ou como afirma TERRADILLOS BASOCO, um limitado banco de provas sobre o que a globalização significa em direito penal.

Um exemplo da coordenação do direito penal nacional ao direito europeu é a discussão do famoso caso submetido ao Tribunal Europeu de Direitos Humanos que considerou que o art. $4^{\circ}$ da lei grega $\mathrm{n}^{\circ} 1.363 / 38$, que previa o crime de proselitismo, contrariava a Convenção Europeia de Direitos Humanos, (Caso Kokkinakis vs. Grécia, $\mathrm{n}^{\circ}$ $14.307 / 88)^{96}$, uma vez que, de acordo com o voto do relator, dado em 1993, "a liberdade de manifestar a sua religião não é apenas exercida coletivamente, em público e no círculo daqueles que compartilham da mesma fé, senão também individualmente e de forma

\footnotetext{
${ }^{94}$ Nos termos da Lei 10.467, de 11 de junho de 2002.

95 VIADA, Natacha G. Derecho penal y globalización, op. cit., p. 59.

96 Tribunal Europeu de Direitos Humanos, Estrasburgo, decisão de 25 de maio de 1993 (trad. livre), disponível em: http://hudoc.echr.coe.int/sites/eng/pages/search.aspx?i=001-57827 (Acesso 8.8.2014).
} 
privada". A Grécia, portanto, não poderia manter o crime de proselitismo em seu sistema jurídico pela decisão do TEDH, pois se entendeu que faz parte do direito de religião tentar convencer o próximo, por exemplo, mediante o ensino, sob o risco de a "liberdade de mudar de religião ou crença", consagrada no artigo $9^{\circ}$ da $\mathrm{CEDH}$, tornar-se letra morta. Este caso representa uma perspectiva de harmonização penal europeia pela descriminalização de condutas que violam a proteção dos direitos humanos. Assim, os direitos humanos não foram tratados como objeto mediato de proteção pela norma penal, mas como critério que orienta sua revogação.

Também quando se pensa em harmonização penal na experiência europeia, há que se fazer referência ao Projeto de Constituição europeia ${ }^{97}$, no artigo 172-III, que prevê a existência de leis marco europeias por meio das quais possam ser estabelecidas normas mínimas para a determinação dos tipos e das penas em termos de criminalidade especialmente graves, de dimensões transfronteiriças, próprias daquele tipo de infração ou da necessidade especial de combaterem-na de acordo com critérios comuns da União ${ }^{98}$.

Ocorre que quando falamos de comunidade internacional temos que enfrentar o problema do déficit democrático que essa nova organização representa, visto que os países são representados em geral por Ministros de Estado, ao passo que a norma penal, em respeito ao princípio da legalidade, emana do Poder Legislativo. Os tratados constitutivos da UE não supõem a transferência do ius puniendi, pois a comunidade carece de um poder punitivo próprio, e seus órgãos não gozam de competência legislativa penal nem podem impor sanções penais ${ }^{99}$. Independente disso, vai-se construindo uma ordem jurídica coordenada em relação aos sistemas repressivos nacionais, costurado pela criação jurisprudencial, que ainda que não transforme o sistema penal de fora pra dentro, para TERRADILLOS BASOCO, impõem uma verdadeira subordinação de suas políticas penais à ordem supranacional, ou, de forma mais amena, para MORILLAS CUEVA, a proteção uniforme, de maneira escalonada e progressiva, coordenada e coletiva dos bens fundamentais para o

\footnotetext{
97 Por extenso, o Tratado que Estabelece uma Constituição para a Europa. Disponível em: http://eurlex.europa.eu/legal-content/PT/TXT/PDF/?uri=OJ:C:2004:310:FULL\&from=ES (Acesso 12.09. 2013).

98 Trata-se especificamente dos crimes de terrorismo, tráfico de pessoas, tráfico ilícito de drogas, lavagem de dinheiro, corrupção, falsificação de meios de pagamento (moeda, entre outros), crimes informáticos, crime organizado, entre outros. HIRSCH, H. J. "Internacionalización del derecho penal y de la ciencia del derecho penal. Ciencia del derecho penal nacional y universal", Revista de Derecho Penal, p. 400.

99 TERRADILLOS BASOCO, “El derecho penal de la globalización (...)”, op. cit., p. 194.
} 
desenvolvimento comunitário, e para as liberdades e direitos de todos os cidadãos, superando os estritos marcos econômicos, que construa um direito penal de caráter internacional ${ }^{100}$.

Para BERDUGO e PÉREZ, a tendência básica do Conselho Europeu, mas também da Comissão e do Parlamento, é claramente uma harmonização extensiva, de incriminação, tendente mais ao aumento do marco de punibilidade, de uma comunidade que encontre mais motivos para punir coletivamente do que para descriminalizar. Ao contrário, à descriminalização tem sido reservado um espaço pequeno, vertida especialmente em relação a condutas que limita a livre circulação de mercadorias e capitais, em respeito mais a interesses nacionais, ou meramente empresariais.

\subsubsection{Consenso na política criminal}

O direito penal globalizado será fundamentalmente orientado segundo as visões, políticas e interesses em vigor na Europa ocidental e Estados Unidos, fornecendo uma moldura a qual se encaixem todos os sistemas nacionais alinhados nessas tradições. Publicamente, refere-se a um atendimento ao clamor público, sendo um lugar-comum, uma prática unânime em torno à regulação de infrações em matérias como o terrorismo com reações firmes por parte dos governos, embora seja discutível que exista um tal consenso em relação a medidas ou instituições jurídico-penais ${ }^{101}$ em implantação. Exemplo dessa situação é a Resolução nº 2178, de 24 setembro de 2014, adotada por unanimidade, pela Assembleia Geral das Nações Unidas para a adoção de medidas para conter o terrorismo, destinada principalmente ao controle de fronteiras, emissão de documentos de viagem e fortalecimento do intercâmbio de informações operacionais relativa à movimentação de terroristas ou de redes de terrorismo, além de ações de aprimoramento da cooperação internacional nessa área.

\footnotetext{
${ }^{100}$ MORILLAS CUEVA, Lorenzo. "Reflexiones sobre el derecho penal del futuro", Revista Electrónica de Ciencia Penal y Criminología, 0406, 2002, p. 19-20.

${ }^{101}$ CANCIO MELIÁ, Manuel, "Internacionalización del Derecho Penal...", p. 230, segundo o autor: "en todo caso, puede constatarse que la demanda indiscriminada de mayores y 'más efectivas' penas ya no es tabú político para nadie; en todo Occidente, y en agentes políticos de muy diversa orientación, el discurso que fía al Derecho penal un papel decisivo en la prevención fáctica del delito es ubicuo".
} 
A resolução recentemente aprovada, ainda, decide que todos os Estados devam assegurar que suas leis nacionais e regulamentos considerem como crimes graves a conduta de pessoa por participação de atos de terrorismo na forma de financiamento, planejamento, preparação ou perpetração, de forma tal que permita processá-la e condená-la ${ }^{102}$. Mais uma vez outorga-se ao direito penal o papel de proteger as nações, a paz, a ordem mundial, os direitos humanos contra as ameaças mais graves que a desordem e a desregulação possam causar: "de imediato, o cidadão se acostuma diante do pano de fundo de determinados cenários [ações terroristas] à completa abolição de sua liberdade sem reconhecer o círculo vicioso: os Estados reagem frente ao injusto com um mega-injusto" ${ }^{\text {"103 }}$. Em defesa de um reposicionamento da estratégia internacional contra-terrorista para que o problema não se torne pior, o presidente da Argentina ${ }^{104}$ ressaltou que acima de tudo, seria crítico assegurar a aderência aos padrões de direitos humanos na luta contra o problema ao invés de reforçar o ciclo de violência e evitar "alimentar o monstro".

A despeito de ações concertadas, o posicionamento no cenário internacional dos Estados Unidos ocorre de modo unilateral quando entendem que pela relevância do assunto eles devam sobrepor seu interesse à atuação nos termos da lei e do direito internacional. Pode-se incluir nessa referência os escândalos que se sucederam com a divulgação de informações de que o governo norte-americano possui uma prática extremamente viciada e ilegal de desrespeitar a privacidade de e-mails e comunicações telefônicas de diversas pessoas ao redor do mundo, como da presidente brasileira Dilma Rousseff e da chanceler alemã, Angela Merkel ${ }^{105}$. A função preventiva do uso do direito penal em perspectiva global justifica que países como os Estados Unidos aprovem legislações específicas nem sempre respeitosas em relação às liberdades digitais fundamentais ${ }^{106}$, sob a justificativa de se fazer um mal menor para se evitar um mal maior, criando regras fora do Estado para se combater

${ }^{102}$ Item 6 da resolução, em tradução livre.

103 ALBRECHT, ZStW, 2005, p. 117, apud CANCIO MELIÁ, M., "Internacionalización del Derecho Penal (...)", p. 230.

${ }^{104}$ V. a cobertura da reunião do Conselho de Segurança, "Security Council Unanimously Adopts Resolution Condemning Violent Extremism, Underscoring Need to Prevent Travel, Support for Foreign Terrorist Fighters", de 24 de setembro de 2014, disponível em http://www.un.org/press/en/2014/sc11580.doc.htm (Acesso 10.10.2014).

${ }^{105}$ V. reportagem publicada pelo jornal inglês The Guardian, "Edward Snowden's Surveillance Report Revelations", disponível em http://www.theguardian.com/world/the-nsa-files, Acesso 27.7.2014, e também no jornal brasileiro Folha de S.Paulo, "Jornalista revelou escândalo de espionagem americana de uma varanda do Rio", disponível em http://www1.folha.uol.com.br/serafina/2014/07/1490619-jornalista-revelou-escandalode-espionagem-americana-de-uma-varanda-no-rio.shtml, Acesso 27.7.2014.

${ }^{106}$ CUESTA, J.L.de la, "Retos y perspectivas...", op. cit., p. 280, especificamente em relação ao Patriotic Act, lei norte-americana publicada como resposta aos ataques terroristas de 11 de setembro de 2001. 
as ações ilegais de outros agentes criminosos e aproveitando-se desse confronto para deixar que dar respaldo ao direito penal, que classicamente já possui regras dentro do direito para tratar comportamentos que violam as regras máximas de convivência social.

Consoante vimos, a primeira força a operar neste cenário é o da liberalização dos fluxos econômicos, a se notar especificamente em relação aos bens e pessoas, e quando os controles migratórios não são insuficientes para respaldar políticas internas de bem-estar social ou de alocação de mão-de-obra, aumentam os desafios criminológicos e de políticacriminal, conforme alertado por DE LA CUESTA, devido acréscimo no número de refugiados, a extensão da exploração e tráfico de pessoas, o incremento do número de crimes de caráter racista ou xenófobo. Assim é que, segundo esse mesmo autor, essa relação da imigração com a percepção social da insegurança cidadã fica cada vez mais estreita - uma percepção fruto de preconceitos, estereótipos e uma leitura enviesada de estatísticas oficiais ${ }^{107}$. Constrói-se, a partir dessa relação deturpada, uma realidade virtual marcada por uma ficção que atribui o problema ao elemento externo, abrindo mão de políticas de integração dos imigrantes, para reforçar o consenso social em torno de uma "sociedade punitiva"108. Há um cinismo aceito de que quando a economia progride, os imigrantes são invisíveis, mesmo sendo necessários, e quando os indicadores econômicos dão mostras de piora, os mesmos imigrantes sobem no ranking dos problemas sociais, mesmo sem deixar de serem necessários.

Não se pode entender a globalização sem identificar a tensão entre essas forças antagônicas, liberação e regulação, mais liberdade e mais virtualização do medo, maior facilidade de transporte e aumento do controle migratório, fortalecimento da proteção dos direitos humanos para a construção de uma cidadania mundial e recurso à sociedade punitiva. Um Estado que cada vez mais perde poder diante dos desafios mundiais colocados pela globalização, paradoxalmente está também mais disposto a outorgar maiores poderes

107 CUESTA, J.L. de la. "Retos y perspectivas...", p. 282; também no mesmo sentido, VIADA, Natacha, Derecho penal y globalización, op. cit., p. 18, a requerer uma resposta adequada por parte do direito penal em nível internacional.

108 GARLAND, D., “As contradições da 'sociedade punitiva': o caso britânico", Revista de Sociologia e Política, 13, 1999, pp. 64 ss., crítico da criminologia como implementada no Reino Unido. Segundo o autor: "nesta linha, nos anos 80 e 90, governos frequentemente adotaram uma posição punitiva que visa a reafirmar a aptidão do Estado a 'governar' simplesmente pela exibição de seu poder de 'punir'. Essa mudança anuncia um novo realismo da representação, mas assinala também o modo pelo qual a justiça criminal se desligou das ideologias de solidariedade" (trad. livre). No mesmo sentido, VIADA, Natacha, Derecho penal y globalización, Madri: Marcial Pons, p. 20. 
para que outros organismos consigam cumprir as expectativas alocadas a ele $^{109}$. Para VIADA, o direito penal sofre de uma ética ambígua para se localizar nesse cenário, uma vez que atua dentro do discurso utilitarista, que busca garantir a lógica e liberdade de mercado, mas também humanista, ligado a proteção de bens comuns da humanidade. O primeiro justifica uma "guerra implacável contra o crime", e o segundo busca a proteção dos direitos humanos. Do primeiro, decorrem as convenções internacionais contra os crimes transnacionais, do segundo surgem os tribunais internacionais ad hoc e o Tribunal Penal Internacional ${ }^{110}$. Será, assim, uma tensão constante entre a máxima liberdade e a máxima repressão em que trafegará o direito penal na globalização.

Em resposta à liberalização propagada pela globalização, seguem-se iniciativas em busca de alguma ordem que ofereça uma alternativa ao discurso pragmático, às perspectivas preventivas do direito penal e à política criminal global. Em alguma medida, a intensificação dos esforços de construção de uma cultura penal compartilhada oferecerá essa resposta ao propor um sistema penal globalizado, por mais distante que isso esteja. Uma cultura penal, nas palavras de DE LA CUESTA, que não pode ser outra que não a dos direitos humanos, únicos valores universais que, apesar das diferenças e dos debates quanto ao seu peso e importância, todos dizem globalmente compartilhar ${ }^{111}$.

Em termos criminológicos, segundo o mesmo autor, a repressão e negação de direitos fundamentais não é a resposta adequada para a prevenção a largo prazo da criminalidade. Resultados associados à prevenção a largo prazo somente podem ser esperados diante de políticas racionais que identifiquem fatores individuais e sociais que promovam a criminalidade, sem cair na simplificação exaltada pela sociedade punitiva, mas que acima de tudo respeitem suas tradições históricas, jurídicas e culturais dentro do "compromisso integral pelos direitos humanos, a serviço da pessoa, da justiça social e da paz" $^{\prime 12}$.

Em termos institucionais, cabe destacar a relevância dos protocolos de investigação judicial e penal, a intensificação da cooperação judiciária e extradição, mas

\footnotetext{
${ }^{109}$ VIADA, Natacha, Derecho penal y globalización (...), op. cit., , p. 17.

${ }^{110}$ VIADA, Natacha, Derecho penal y globalización (...), op. cit., p. 24.

${ }^{111}$ CUESTA, J.L. de la, "Retos y perspectivas (...)", op. cit., p. 283 ss.

${ }^{112}$ CUESTA, J.L. de la, "Retos y perspectivas (...)", op. cit., p. 284.
} 
sobretudo da configuração da jurisdição penal universal e da Corte Penal Internacional e Tribunais ad hoc, ou, ainda de um movimento que desembocará finalmente num espaço penal europeu, com normas penais, processuais e controle judicial europeu comum (euroordem $)^{113}$. Assim, a harmonização que se está a assistir no plano internacional em torno do direito penal passa pela renovação experimentada na proteção internacional dos direitos humanos e consideração de que a violação em casos de crimes contra a humanidade atinge não o indivíduo, mas a humanidade inteira, instrumentalizando o sujeito que representa a vítima para além dela. Essa consideração ocorre a partir da jurisprudência do TPII, no caso Erdemovic ${ }^{114}$, ao afirmar que "diferentemente do direito, o objeto do dano não é mais a integridade física da vítima, mas a humanidade inteira. (...) esses crimes transcendem também o indivíduo, pois, ao ser atacada a pessoa, está sendo visada e negada a humanidade".

A comunhão de valores universais, subscritos sob a rubrica dos direitos humanos ou de que o ataque produzido por uma ação é contra a humanidade, contém uma aspiração articulada de objetivos de uma sociedade. A vivência global desses objetivos é o que chamamos de consciência do mundo todo. Um bom exemplo desta consciência é a maneira como surgiram dezenas de comissões da verdade no mundo todo a partir da experiência na África do Sul. O reconhecimento da vivencia compartilhada de uma situação de supressão de direitos humanos e a forma alternativa como essa situação foi revista em diversos países motivou a criação de novas comissões, cada uma com seus escopos especiais, esperando-se que com isso as mesmas violações não voltassem a se repetir.

As perspectivas ensejadas ao direito pela globalização, em especial ao direito penal, contém tanto elementos positivos como negativo, como não poderia deixar de ser em relação a um movimento dialético, mas necessariamente aberto, imperfeito e incontrolável. Quanto aos negativos, FERRAJOLI aponta o reconhecimento da incapacidade do direito penal em fazer frente às causas estruturais da criminalidade, executando um programa dirigido a secundar, ou ainda pior, alimentar os medos e tendências repressivas da

\footnotetext{
113 ARROYO ZAPATERO, Luís. “A harmonização internacional do direito penal...”, op. cit., p. 74. V. igualmente BASSIOUNI, M. Cherif. "International Criminal Justice in the Age of Globalization”, op. cit., pp. 79-81.

114 TPII, Caso Edermovic, decisão de 26.11.1996 (IT-96-22-T), § 20: “As opposed to ordinary law, the violation here is no longer directed at the physical welfare of the victim alone but at humanity as a whole".
} 
sociedade $^{115}$. Quanto aos positivos, DELMAS-MARTY aponta para as oportunidades afiançadas às chamadas capacidades criativas do direito. A autora pondera que há que se fazer um esforço não para se opor à globalização de forma dogmática, mas de, tomando por base as circunstâncias, buscar a criação de respostas, num processo de inovação do direito ${ }^{116}$. Essa resposta estaria na busca de uma ordem plural, em contraposição a uma ordem única hegemônica, mas de alguma forma expressado, posto, concertado, para que não configure uma desordem invencível. A capacidade criativa do direito remonta, assim, a uma técnica, a soluções que ainda não estão postas, mas que o sistema jurídico vigente dá conta de fornecer, claramente orientado pela solução que seja legítima e conforme os padrões universais de respeito aos direitos humanos e à ordem internacional baseada neles.

O direito penal capta os desenvolvimentos da sociedade moderna, conectada globalmente, dentro de marcos jurídicos concretos, por meio da "sensação de cidadania do mundo", como em casos extremos diante de genocídios como na Iugoslávia e em Ruanda, o pedido de extradição envolvendo o general chileno Pinochet por crimes perpetrados pelo seu governo durante a ditatura chilena, ou as ilegalidades associadas à guerra do Iraque ${ }^{117}$, com suas três consequências de maior relevo: o conceito de guerra de agressão ${ }^{118}$, o uso da base militar como prisão, em Guantánamo ${ }^{119}$ e as prisões secretas e tortura, sendo a mais famosa a de Abu Ghraib. Esse movimento se reflete de forma muito clara na jurisprudência da Corte Interamericana de Direitos Humanos - CorteIDH pela condenação de países que aprovaram leis de anistia aos seus ditadores, determinando-se sua revogação, como decidido no caso Barrios Altos c. Peru, de 14.03.2011, ou os mandados de criminalização ${ }^{120}$ para que os países em que os atos considerados pela CorteIDH como criminosos condenem o fato com base no direito nacional ou também as obrigações positivas de natureza penal emanadas das decisões

\footnotetext{
115 VIADA, Natacha, Derecho penal y globalización (...); op. cit., p. 22.

116 DELMAS-MARTY, Mireille. "Lo relativo y lo univeral - Études juridiques comparatives et internationalisation du droit", op. cit.

117 ARROYO ZAPATERO, Luíz, “A harmonização internacional do Direito Penal: ideias e processos”, op. cit., pp. 71-72.

118 BROTÓNS, Antonio Remiro. Agresión, crimen de agresión, crimen sin castigo, Documentos 10, Friede.org, Madri, 2005.

119 AVELAR, Idelber. “Desconstruindo o 'humano' em 'direitos humanos': Vida nua na era da guerra sem fim”, Revista Estudos Políticos, julho/2011 (disponível em http://revistaestudospoliticos.com/desconstruindoo-\%E2\%80\%98humano\%E2\%80\%99-em-\%E2\%80\%98direitos-humanos\%E2\%80\%99-vida-nua-na-era-daguerra-sem-fim/, Acesso 05.08.2014).

${ }^{120}$ RAMOS, André de Carvalho. "Mandados de criminalização no direito internacional dos direitos humanos: novos paradigmas da proteção das vítimas de violações de direitos humanos", RIBCCRIM 62, 2006.
} 
da CorteIDH ${ }^{121}$. Ao colocar os países no banco dos réus por violações de direitos humanos, consagra-se uma nova tendência de obrigação dos Estados em reparar as violações, indenizar as vítimas e rever normas que estão em desarmonia com o sistema de proteção dos direitos humanos.

O discurso de direitos humanos se converte em um campo de consenso de prática e de política, inclusive para uso do aparato penal diretamente pelos Estados, ou penalizante, por meio de mandamentos de criminalização, conforme decisões da CorteIDH, ainda que para tanto haja que se recorrer às capacidades criativas do direito e equacionar as diferenças e ambiguidades da prática de direitos humanos, conforme veremos no subcapítulo seguinte.

\subsection{Expansionismo Penal e Direitos Humanos}

\subsubsection{Direito Penal e Direitos Humanos}

A interferência do conceito de direitos humanos para o direito penal não é assimilada com facilidade. A aproximação a um novo arcabouço conceitual, do qual certamente o direito penal recebe influência, favorece uma reflexão inclusive sobre os objetivos e limites do direito penal contemporâneo. $\mathrm{O}$ direito penal, instrumento de controle social $^{122}$ que busca a manutenção da expectativa de cumprimento do pacto de convivência, aceitaria a interferência de concepções humanistas e não puramente funcionais, burocráticas e desumanizadas que organizassem sua estrutura interna ${ }^{123}$.

\footnotetext{
121 V. MARTIN-CHENUT, Kathia. “A valorização das obrigações positivas de natureza penal na jurisprudência da CorteIDH: o exemplo das graves violações de direitos humanos cometidas durante as ditaduras dos países do Cone-Sul" (trad. Priscila Akemi Beltrame e Pedro Augusto Simões da Conceição), RIBCCRIM 103, 2013.

122 Para maior aprofundamento, BUSTOS RAMÍREZ, J. Control social y derecho penal. Barcelona: PPU, 1987, pp. 457 ss; BARATTA, Alessandro. Criminologia crítica e crítica do direito penal. Rio de Janeiro: Ed. Revan, $3^{\mathrm{a}}$ ed., 2002.

${ }^{123}$ HASSEMER, W. Persona, mundo y responsabilidad. Bases para una teoría de la imputación en Derecho Penal (trad. Muñoz Conde/Díaz Pita), Tirant lo Blanch, 1999, p. 15.
} 
Assim é que o direito penal refletirá a orientação jurídico-filosófica e a ideologia política vigentes ${ }^{124}$, podendo essa orientação, a partir da referência constitucional do direito penal, vir dos direitos fundamentais. O certo é que a perspectiva dos direitos humanos sempre esteve presente no sistema penal, contaminando seu raciocínio, especialmente dentro do modelo social personalista, que enxerga a realização dos direitos do indivíduo o fim a ser buscado socialmente, sendo o Estado um instrumento a seu serviço ${ }^{125}$. Esse movimento abrange necessariamente a constitucionalização do direito penal por que passaram os Estados europeus mediterrâneos a partir do final dos anos 70 com as novas constituições da transição democrática, as transformações políticas da Europa do Leste nos anos 90, ou pela renovação das constituições na América Latina, por meio da integração dos valores universais dos direitos humanos nos sistemas jurídicos como valor jurídico imanente ${ }^{126}$. Tal como presente na Constituição brasileira, o quadro axiológico lá consagrado informa a atuação dos poderes públicos na especial relação entre poder e direito, para que o direito penal, como subsistema do sistema de controle social, atue sempre que seu âmbito de proteção se revelar imprescindível à manutenção da ordem social. Desta forma, o direito penal, na defesa dos direitos humanos, na dimensão punitiva, atuará apenas de maneira subsidiária e fragmentária ${ }^{127}$. Isso porque os fins dos direitos humanos não podem ser confundidos com a atribuição do direito penal, de larga trajetória e que não pode expandir seu escopo sob pena de fratura de sua espinha dorsal: o equilíbrio entre a defesa das garantias e a punição à violação da norma penal.

Daí porque uma violação a um direito humano nem sempre será considerada uma violação com relevância penal, se não ficar evidenciado o percurso da conduta pelo tipo penal. Por exemplo, a reintegração de posse por parte do titular da propriedade invadida, violando o direito à moradia, não será considerada crime; ou a ausência de vaga em escola

\footnotetext{
${ }^{124}$ CAMARGO, Antonio Luís Chaves. Sistema de penas, dogmática jurídico-penal e política criminal. São Paulo: Cultural Paulista, 2002.

${ }^{125}$ Essa orientação opõe-se, portanto, àquela que pretende garantir a manutenção da estrutura de poder como o fim último do Estado, justificada por uma superestrutura legitimante. Faz referência a esta bipartição BERDUGO GÓMEZ DE LA TORRE, I.; PÉREZ CEPEDA, A. "Derechos Humanos y Derecho Penal (...)", op. cit., p. 81.

${ }^{126}$ Trata-se, conforme ARROYO ZAPATERO, Luís, da conversão da Declaração de Direitos do Homem e do Cidadão, da Revolução Francesa de 1789, em elemento material da realidade jurídica dos povos e da consciência jurídica do conjunto dos povos do mundo. Essa dimensão favorece a atuação em rede, como sustenta BASSIOUNI, cuja eficiência já se comprovou em relação ao setor financeiro e dos negócios. V. ARROYO ZAPATERO, Luís . "A harmonização internacional do Direito Penal: ideias e processos", op. cit., p. 56, e BASSIOUNI, M. Cherif. "International Criminal Justice in the Age of Globalization", op. cit., pp. 7981.

${ }^{127}$ BECHARA, Ana Elisa. "Derechos humanos y limites(...)”, op. cit., pp. 122 e 123.
} 
pública, violando o direito à educação; ou a ausência de leito hospitalar, violando o direito à saúde.

Entretanto, como vem sendo defendido no âmbito de proteção internacional dos direitos humanos, está-se a inverter o princípio da subsidiariedade do direito penal por meio da jurisprudência das cortes de direitos humanos, que como um "direito odioso", "instrumento brutal" e que portanto deveria ser utilizado como última opção, passa a se tornar um meio prioritário de ação ${ }^{128}$ e por essa razão essa relação ainda apresenta elementos de tensão e fragilidade.

Conquanto a reflexão sobre as influências dos direitos humanos sobre o direito penal se aprofunde no capítulo terceiro deste trabalho, faz-se necessário uma abordagem inicial pois sua captação é essencial para justificar a transição do capítulo primeiro ao segundo, que refletirá sobre a expansão do direito penal rumo ao fortalecimento do direito penal internacional, tendo o clamor pela universalização dos direitos humanos seu grande motor.

Com razão, Álvaro PIRES apresenta o paradoxo existente na afirmação dos direitos humanos e a marca característica do direito penal mínimo, de ultima ratio: sua fragmentaridade e a vertente criminológica que afirma que o aumento das penas não resulta em redução da criminalidade. A pena aflitiva, no entender do autor, é frequentemente valorizada num discurso combativo às violações dos direitos humanos. Ao clamar por mais punição e aumento de pena, produz um resultado paradoxal: potencializada o discurso punitivo, muitas vezes fazendo coro e engrossando o clamor por maiores penas ao lado do discurso moralista, paternalista do direito penal, em resistência a outros tipos de sanções. Mas também fará parte do discurso dos direitos humanos a redução das penas e a diversificação das sanções. "Para a racionalidade penal moderna, tudo se passa como se o direito penal não pudesse defender os direitos humanos e ao mesmo tempo devesse exprimilos de forma positiva, concreta e imediata" ${ }^{29}$. A matriz de direitos de cada uma das áreas é

\footnotetext{
${ }^{128}$ MARTIN-CHENUT, Kathia. “A valorização das obrigações positivas de natureza penal na jurisprudência da CorteIDH...", op. cit., p. 101.

${ }^{129}$ Igualmente, afirma: "Algumas dessas demandas de punição ou de imposição de sofrimento estão sendo formuladas em nome dos direitos humanos (isto é, de princípios como a igualdade perante a lei, a dignidade humana, etc.), ou de um tema associado aos direitos humano (ódio racial, discriminação, etc.). Ora, não estamos diante de um paradoxo? Como podemos mobilizar direitos humanos para pedir menos direitos humanos sem
} 
distinta e portanto, não dificilmente poderiam chegar à realização do mesmo objetivo. Talvez, a iluminação transversa de uma área à outra pudesse produzir efeitos de, dentro de sua respectiva cadeira, visualizar o espectro de direitos que tem diante de si e, para além das divergências, buscarem o mesmo objetivo: a realização dos direitos humanos em sociedade, entendidos para além do escopo punitivo e abrangendo a máxima realização das garantias. Da perspectiva dos direitos humanos, reivindicar formas alternativas de composição dos danos não apenas pelo recurso à pena aflitiva, e da perspectiva do direito penal, pela humanidade das penas, ressignificação dos valores protegidos por meio da dignidade da pessoa humana e fortalecimento da perspectiva da vítima em direito penal.

FIGUEIREDO DIAS reflete sobre a existência de múltiplas normas internacionais de conteúdo jurídico-penal e de relevo indiscutível para a aplicação do direito penal e, para o Estado nacional, o dever de implementar políticas criminais convencionadas ${ }^{130}$. Assim, os direitos fundamentais presentes no âmbito internacional, por meio de convenções e tratados de direitos humanos, ou no âmbito nacional, com acento constitucional, exprimem valores que ancoram o exercício dos poderes do Estado. Nas palavras de BERGUDO e PÉREZ, “o sistema social configurado na Constituição tem projeção sobre as duas perspectivas desde as quais se pode considerar o direito penal", como instrumento que busca evitar comportamentos que perturbem a ordem social (no qual os direitos humanos situam-se como objeto de proteção) e como autolimitação do Estado (no qual os direitos humanos limitam o poder sancionador do Estado e, por isso, fixa um sistema de garantias dos cidadãos potenciais agressores). Isso porque a partir de conceitos fortalecidos a partir de meados do séc. XX como valor normativo da Constituição e a vinculação da jurisdição aos direitos fundamentais, ganha força o mandamento dos direitos fundamentais de impor obrigações e criar proibições aos poderes públicos conferindo uma dimensão substancial à democracia ${ }^{131}$.

\footnotetext{
que isso pareça contraditório, chocante ou pelo menos embaraçoso?". PIRES, Álvaro. "A racionalidade penal moderna, o público e os direitos humanos". Novos Estudos, CEBRAP, vol. 68, março/2004, p. 55.

${ }^{130}$ FIGUEIREDO DIAS, Jorge de, Direito Penal - Parte Geral, Ed Revista dos Tribunais e Coimbra Editora, 2007, pp. 10 ss., distingue normas, instrumentos e princípios presentes nos tratados internacionais com reflexos diretos para os indivíduos, ao contrário do direito internacional clássico, que tratava apenas os Estados como sujeito de direitos na órbita internacional. Com relação ao direito português, indica que estas normas vigoram ao lado ou mesmo acima das leis ordinárias.

${ }^{131}$ FERRAJOLI, L. "La democracia constitucional". In: CARBONELL (ed.), FERRAJOLI, L. Democracia y Garantismo, Madri: Ed. Trotta, 2010, p. 32.
} 
As garantias, em sentido amplo, diferenciam-se dos objetos de proteção, e podem ser entendidas como os instrumentos por meio dos quais o direito protege e tutela referido bem ou valor, ou mais especificamente, as técnicas de tutela dos direitos fundamentais ${ }^{132}$. Em relação ao direito penal, de forma semelhante, BECHARA trata da função dupla do direito penal na proteção dos direitos fundamentais: afirmar positivamente seus valores e atribuir o caráter delitivo em caso de transgressão daqueles valores ${ }^{133}$. Há, assim, uma forte relação, inclusive de atribuição de significado e pertinência, entre o direito penal e as garantias dos direitos fundamentais. A teoria geral do garantismo estabelece, portanto, imperativos substanciais ao direito positivo para a perseguição do horizonte de valores inscritos na Constituição. É o estatuto do direito de liberdade, pois titulares são todos os seres humanos, sendo sua consagração pelo do Estado de Direito o melhor sistema que consegue equalizar o gozo do direito de liberdade dos cidadãos, com segurança e convivência social harmônica, e as condições (materiais, processuais, judiciárias) para sua limitação.

Sustenta-se que os direitos humanos serviriam como ponto de partida ideológico para a política criminal ${ }^{134}$. Não se fixa uma relação de hierarquia, nem tampouco de separação estanque entre os sistemas, mas de um diálogo intenso mediado pelos fundamentos do direito penal (extraídos inclusive dos próprios direitos humanos), mas que não permite que o sistema repressivo seja instrumentalizado a um fim de encontrar nos direitos humanos uma "superestrutura legitimante". Um diálogo ruidoso, portanto, que ora se aproxima, ora se aparta, buscando encontrar um ponto de equilíbrio para além do casuísmo, da conveniência ou convergência ideológica de quem fala em seus nomes. É com frequência que se vê o direito penal atacado em sua dimensão garantista, pois se entende que essa dimensão prejudica a realização da eficácia punitiva ${ }^{135}$. Conforme entende BECHARA, nesses modelos que de fato se distanciam do paradigma penal liberal, sustentados por uma

\footnotetext{
132 FERRAJOLI, L. "La democracia constitucional”, op. cit., p. 60.

133 BECHARA, Ana Elisa Liberatore. "Derechos humanos y límites de la intervención penal en Brasil". RIBCCRIM, ano 18, nº 85, jul-ago/2010, p. 120.

${ }^{134}$ A este respeito, especialmente em relação ao renovado papel da política criminal em direito penal, v. BUSTOS RAMÍREZ, J. Control social y sistema penal, Barcelona: PPU, 1987, pp. 513 ss.

135 Interessante considerar que essa dicotomia entre uma função legitimante e eficiente estava na raiz da formação do Estado Democrático de Direito, caracterizado pela tentativa de construção de uma sólida e fecunda relação entre Têmis e Leviatã, de uma justiça que não seja apenas uma dimensão transcendente e o poder não seja mera facticidade. Esse tema, dentro da metáfora de Têmis e Leviatã, é abordado na obra Entre Têmis $e$ Leviatã: uma relação difícil. O Estado Democrático a partir e além de Luhmann e Habermas, de Marcelo NEVES. São Paulo: Martins Fontes, 2008.
} 
ideologia que defende a manutenção da ordem pública e da segurança coletiva contra conhecidos inimigos, produz-se por efeito um autoritarismo que segrega, por meio do direito penal, os setores sociais mais frágeis na instrumentalização das garantias do mesmo direito penal.

O fortalecimento do direito penal e a busca de sua eficiência, ativando um direito penal máximo, no famoso binômio de FERRAJOLI (contraposto ao direito penal mínimo ${ }^{136}$ ) pretende que por ele se atinjam objetivos do Estado alheios à sua missão: resolver os problemas sociais que geram a violência pela função de prevenção geral da pena. Ao prevenir o delito, desaparecem os conflitos e inocula-se a violência. O direito penal exerce um poder atrativo no imaginário popular, haja vista o constante apelo ao seu discurso em qualquer campanha eleitoral ${ }^{137}$, para qualquer cargo (sob o discurso de proteção da população e fortalecimento da polícia), e seu efeito simbólico ${ }^{138}$, substituindo, aparentemente, as políticas públicas deficientes do Estado ${ }^{139}$.

BURCHARD nos faz perguntas fundamentais para entender, afinal, o que estudamos quando estudamos direito penal: qual é sua função? E, por conseguinte, onde se encontram os limites do direito penal do Estado, ou seja, de seu ius puniendi? O direito penal de hoje é distinto do de duas décadas atrás precisamente na resposta a estas questões. A teoria do bem jurídico, que ajuda a responder essas questões, tem suas raízes no séc. XVIII e XIX, portanto, pré-constitucional, considerando que o Estado somente pode sancionar pela norma penal quando ocorrer a lesão ou a ameaça de lesão a um bem jurídico, como limite

${ }^{136}$ FERRAJOLI, L. Derecho y Razón Teoria del garantismo penal (Trad. Perfecto Andrés Ibánez et. al.), Madri: Editoral Trotta, terceira edição, pp. 103 ss., referindo-se a sistemas com maiores ou menores garantias estruturalmente internas ao sistema, assim como a quantidade e qualidade das proibições e das penas, sendo comum que os sistemas encontrem-se entre um limite e outro. É característica do direito penal mínimo, portanto, a preservação do cidadão diante do arbítrio punitivo, diante de um sistema que se oriente pela racionalidade e certeza (intervenções previsíveis e com base em verdades fáticas).

${ }^{137}$ Em igual sentido, afirma-se que o desacerto de uma legislação penal atribui-se a seu caráter simbólicoenganoso ao mesmo tempo que ao aumento do populismo com que a política criminal invade os partidos políticos, motivando decisões irracionais, visando simplesmente o voto da população. KUHLEN, Lothar. "La autocomprensión de la ciencia del derecho penal frente a las exigencias de su tiempo". In: ESER, Albin; HASSEMER, Winfried; BURKHARDT, Björn (coord.). La ciencia del derecho penal ante el nuevo milenio. MUÑOZ-CONDE, Francisco (coord. versão espanhola). Valência: Tirant lo Branch, 2004, p. 76.

${ }^{138}$ Diz-se do uso simbólico do direito penal quando se refere a uma criminalização desproporcionada e oportunista, muitas vezes sem operatividade prática, e que se aparta dos fins tradicionais da pena, transmitindo à população a existência de uma autoridade estatal forte e pujante em seu objetivo de reagir ao ato reprovado pela maioria. Neste sentido, CANCIO MELIÁ, Manuel. "De nuevo 'Derecho Penal' del enemigo?", In: CANCIO MELIÁ, M.; GÓMEZ-JARA DIEZ, Carlos (eds.), Derecho Penal del Enemigo, el discurso penal de la exclusión, Vol. 1, DdeF, 2006, p. 345.

${ }^{139}$ BECHARA, "Derechos humanos y límites de la intervención penal”, op. cit., p. 129. 
legitimador e ao mesmo tempo restritivo de atuação do Estado. Entretanto, o próprio Tribunal Constitucional alemão, ao pronunciar a decisão em 2008 (BVerfGE120, p. 241) afirma que: "Conforme a Constituição, as normas penais não estão sujeitas a nenhuma exigência que se possa derivar da teoria do bem jurídico em matéria penal", alimentando a crítica acerca do esgotamento da teoria. Entre as críticas, ressalta-se o entendimento de que a teoria do bem jurídico não estaria apta a justificar a incidência da norma penal em relação à criminalidade moderna, mas apenas a "criminalidade aventureira e da miséria', de um direito penal que se concentra na proteção de bens jurídicos individuais (como a vida e a propriedade), e o aplicável aos delitos clássicos de resultado (ação, resultado, imputação objetiva), principalmente voltado à classe baixa. Um moderno direito penal também serviria para proteger as funções do sistema capitalista, como um bem jurídico, mas de outra natureza (alargando-se seu critério de limitação) ${ }^{140}$, quiçá na mesma ordem de pensamento já anunciada por BUSTOS RAMÍREZ ${ }^{141}$, de preparação de um sistema penal democrático aparece aberto em sua base de legitimação, por meio da teoria do bem jurídico, necessariamente relativo e em constante desenvolvimento, por seu caráter comunicativo, participativo e dialético.

Tampouco podemos concordar com a manipulação do conceito de modo a usálo contra sua vocação original, que de limite de intervenção penal passa a ser considerado como critério positivo de justificação. Como forma de garantir a vocação liberal do Estado e sua vinculação com o direito penal, protegendo os valores individuais, é apresentado o conceito de bem jurídico por BIRNBAUM como limite à atuação do Estado, extraindo uma referência material à proteção da norma penal. Diversas críticas têm sido feitas ao rendimento da teoria do bem jurídico diante de novos bens, supraindividuais, espiritualizados, crimes sem bem jurídico, que sua força está à prova.

Isso porque, para BURCHARD, baseado em FRISH e WEIGEND, ao não se apresentar a teoria do bem jurídico como um critério com contornos muito bem definidos, deixa portas demasiadamente abertas às preferências subjetivas, movida "por um

\footnotetext{
${ }^{140}$ BURCHARD, Christoph. "O princípio da proporcionalidade no direito penal constitucional ou o fim da teoria do bem jurídico tutelado na Alemanha". In: AMBOS, Kai; BÖHN, Maria Laura (coord.), Desenvolvimentos atuais das ciências criminais na Alemanha. Brasília: Gazeta Jurídica, 2013, pp. 38-40. FRISH, An den Grenzen des Strafrechts, Festshrift Stree/ Wessels, 1993, p. 69, 74. WEIGEND, Leipziger Kommentar, $12^{\text {a }}$ ed. 2007. Einleitung, apartados. 7 ss.

${ }^{141}$ BUSTOS RAMÍREZ, J. Control social y derecho penal. Barcelona: PPU, 1987, p. 33.
} 
decisionismo e intuicionismo que, não obstante, são encobertos pelos axiomas de cada teoria do bem jurídico"142. Assim, para o autor, as mais variadas leituras da teoria, nota-se que cada um dos bens jurídicos protegidos nos diferentes crimes implica avaliações político-criminais concretas que não podem ser igualmente generalizadas, o que permite que o conceito de bem jurídico possa ser livremente manipulado, e que um jurista com "boas qualidades retóricas possa inventar bens jurídicos com facilidade" ${ }^{" 43}$. Por outro lado, o bem jurídico é um modelo teórico e como tal dialoga com a realidade para impor e aceitar limites, ou seja, "uma síntese normativa concreta de relação social determinada e dialética"144. Não pode funcionar como uma camisa de força, do contrário seria em si autoritária e correria o risco de se asfixiar, pois as condutas delitivas assim como os tipos podem variar dependendo dos valores orientadores da sociedade, seu maior ou menor grau de relevância para o convívio. É certo que a criminalidade alterou-se, a inteligência por trás das investigações, da prova, mas parece precipitado indicar que a teoria do bem jurídico sirva para uma categoria de crime e não para outra, conforme o extrato social visado. Concordamos que a teoria carece de adaptação, mas não por isso podemos concordar que seja abandonada.

\subsubsection{Valores Penais Humanos}

O universo principiológico com que qualquer estudo em direito penal se depara remete à consideração de princípios como da legalidade, da lesividade e do caráter fragmentário do direito penal, para citar alguns. Todos os princípios têm como referência a realização do valor máximo do indivíduo e de sua dignidade ${ }^{145}$, núcleo extremo dos direitos humanos e do Estado Democrático de Direito brasileiro que passa a se determinar a partir da função limitadora dos princípios constitucionais sobre o poder punitivo do Estado, fornecendo o equilíbrio entre a realização dos direitos individuais e a proteção frente ao

\footnotetext{
${ }^{142}$ BUSTOS RAMÍREZ, J. Control social y derecho penal, op. cit., p. 38 (trad. livre).

${ }^{143}$ BUSTOS RAMÍREZ, J. Control social y derecho penal, op. cit., p. 39, citando, especificamente no caso da Alemanha, mas igualmente aplicável à realidade brasileira, o bem jurídico saúde pública, que legitima a aplicação de sanções penais quando um cidadão adquire drogas para consumo próprio. A facilidade de se atribuir um bem jurídico a uma conduta que o legislador quer criminalizar dificulta a própria negação desse tipo de crime como insubsistente dentro de um direito penal democrático.

${ }^{144}$ BUSTOS RAMÍREZ, J. Control social y derecho penal, op. cit., p. 33.

145 Afirma-se que todo o ordenamento jurídico terá que ser visto a partir do respeito à dignidade humana, visto que esse princípio encontra-se subjacente a todos os direitos fundamentais. Subjaz-se a todos e a cada um dos direitos constitucionais a dignidade, conforme trata, GÓMEZ PAVAJEAU, Carlos Arturo, "La teoría del sujeto de derecho penal”, Derecho Penal y Criminología: Revista del Instituto de Ciencias Penales y Criminológicas, vol. 33, n'. 93, 2011, pp 27-42.
} 
arbítrio estatal. Assim é que BUSTOS RAMÍREZ afirmou que o direito penal deverá construir-se a partir do princípio constitucional da dignidade da pessoa, de seu reconhecimento como categoria autônoma frente ao Estado, quaisquer que sejam suas condições e características"146. A dignidade humana, a partir da II Guerra Mundial em que se inaugura uma nova época de convivência dos povos sob a consideração dos valores expressivos dos direitos humanos, passa a elevar a dignidade humana como categoria de núcleo axiológico constitucional, e em decorrência, de valor jurídico supremo. Além da Constituição Federal brasileira ${ }^{147}$, e do Pacto Internacional de Direitos Políticos e Civis ${ }^{148}$ a promoverem a dignidade humana, podemos citar sua previsão em Constituições como o art. $1^{\mathrm{o}}$ da Constituição de Portugal, o art. $1^{\circ}$ da Constituição da Alemanha (1.1), o art. 10.1 da Constituição Espanhola, o art. $1^{\circ}$ das Constituições da Colômbia, Chile e do Peru, entre outras, além dos diversos tratados e convenções da família das Nações Unidas e dos sistemas regionais de proteção de direitos humanos.

Os valores subjacentes à dignidade humana estarão presentes no sistema, considerando-se tanto a Constituição, quanto tratados internacionais em vigor e não são estáticos, mas à medida da integração das sociedades, deve refletir uma comunhão de valores sobre os quais as sociedades razoavelmente acham-se assentadas. Se num primeiro momento a ideia era retirar da incidência da norma penal os comportamentos de desvalor ético ou religioso, aos poucos passou-se a olhar o direito penal com o filtro da Constituição, Declaração Universal dos Direitos do Homem e do Cidadão e tratados internacionais de direitos humanos. A sujeição aos tratados de direito internacional também impõe o respeito à dignidade humana e, em consequência, funcionam como limitação ao poder estatal. São claros, portanto, os valores presentes que se lançam sobre o direito penal que estará cada vez mais orientado pelo diálogo criativo e com os direitos fundamentais. Resta perquirir se a expansão do direito penal tendo como base uma nova dogmática que incorpore os direitos humanos como limite à intervenção punitiva do Estado justificaria o desenvolvimento do

\footnotetext{
${ }^{146}$ BUSTOS RAMÍREZ, J. Los mitos de la ciencia penal del siglo XX: la culpabilidad y la peligrosidad en La Ciencia del Derecho Penal ante el Nuevo Siglo. Libro Homenaje al Profesor José Cerezo Mir. Madrid: Tecnos, 2002 , p. 7.

${ }^{147}$ Art. $1^{\circ}$, inc. III, como fundamento da República Federativa do Brasil.

${ }^{148}$ Mencionado no preâmbulo como direito "inerente a todos os membros da família humana e dos seus direitos iguais e inalienáveis constitui o fundamento da liberdade, da justiça e da paz no Mundo"; e ainda "estes direitos (iguais e inalienáveis) decorrem da dignidade inerente à pessoa humana"; e prevista como direito no art. $10^{\circ}$ : "Todos os indivíduos privados da sua liberdade devem ser tratados com humanidade e com respeito da dignidade inerente à pessoa humana".
} 
direito penal internacional, como abordaremos adiante. Apoia essa interação a crítica feita por Álvaro PIRES com relação ao modelo como o direito penal se impõe, com uma racionalidade fundada na pena aflitiva, próprio de uma consciência colonizada, que apenas consegue raciocinar o direito penal em cima do raciocínio: "aquele que fez x pode ou deve ser punido com y", sendo a pena de prisão o auto-retrato identitário do sistema penal ${ }^{149}$.

Retomando, assim, nossa análise da teoria do bem jurídico, tendo passado pelas considerações a respeito da dignidade humana, não se trata de substituir a função do bem jurídico na dogmática penal, pois consideramos sua teoria potente e robusta a fundamentar a intervenção da norma penal. Muito menos a de substituí-lo pelo conceito de direitos humanos, justamente por ser um conceito ainda demasiado amplo, que pode significar tudo e nada ${ }^{150}$, com foco ainda ligado à criminalização de condutas e punição, desnaturando a função garantista do direito penal ${ }^{151}$; finalmente porque os direitos humanos tendem a expansão ao passo que o direito penal requer condições muito mais robustas para justificar a punição às violações da norma penal, quando a intervenção do direito penal ocorrerá apenas como último recurso e imprescindível para a convivência social ${ }^{152}$.

Poder-se-ia pensar numa forma de sistematização na qual os direitos humanos com conteúdo de direito penal dependeriam da máxima autorização democrática (legislativa, material, processual e judicial) para punir assim como da máxima renovação legislativa (nesse caso, numa nova Constituição) para suprimir as garantias penais e processuais penais (sendo certo que no sistema brasileiro não será objeto de deliberação a proposta de emenda constitucional tendente a abolir os direitos e garantias fundamentais ${ }^{153}$ ). Por outro lado, os direitos humanos de base social, cultural, econômica tenderiam a expansão por meio de realização de políticas públicas ou contextos econômicos favoráveis às suas realizações. Ainda que a classificação dos direitos humanos tenha sido elaborada em gerações ${ }^{154}$, mas a

${ }^{149}$ PIRES, Álvaro. “A Racionalidade Penal Moderna, o público e os direitos humanos”, Novos Estudos, nº 68, p. 40-41.

${ }^{150}$ Assim, Upendra BAXI critica a amplitude com que se afirmam os direitos humanos ao descrever o seu objeto de estudo como sendo formas flexíveis, protótipos, de ação social reunidas, por convecção, sob um portal chamado "direitos humanos". The future of human rights. Oxford: Oxford University, 2002, p. 5.

${ }^{151}$ Como novas categorias criminais, a criminalização do feminicídio, ou da homofobia, para ficar em dois exemplos atuais em discussão no Brasil.

${ }^{152}$ Essas considerações têm sofrido profundas alterações pela teoria da expansão do direito penal e do direito penal de duas velocidades, consoante abordaremos no item 1.4.2.

${ }^{153}$ Cláusula pétrea da Constituição Federal, art. 60, § $4^{\circ}$, IV.

${ }^{154}$ A divisão dos direitos humanos em gerações foi incialmente concebida pelo jurista tcheco Karel VASAK em sua obra "Human Rights: A Thirty-Year Struggle: the Sustained Efforts to give Force of law to the 
proposta em questão é de outra natureza, pois pretende identificar como direitos humanos de conteúdo de direito penal (material e processual) aqueles cuja extinção, ampliação ou redução teriam impacto na invocação de um direito em juízo (para acusar ou para defender). Assim, podemos recorrer à sistematização proposta por Álvaro PIRES quando trata dos direitos humanos de duas categorias: os direitos-barreira ou de proteção (“direitos de...") e os direitos-à-obtenção (“direitos a...”). Os primeiros visam garantir uma zona de autonomia individual, limitando a ingerência do Estado (e particulares) na vida dos indivíduos, funcionando como garantias dos cidadãos diante do Estado, de conteúdo material mas também processual. Os segundos são direitos que visam a promoção do bem-estar dos cidadãos, direitos ligados a uma prestação do Estado.

Interessante notar que muito das críticas que são dirigidas à teoria do bem jurídico, como mencionado acima, também podem ser atribuíveis à teoria dos direitos humanos. Assim, FERRAJOLI denuncia que a maior parte dos direitos de nossa tradição jurídica não se debruçou nas técnicas de garantia tão eficazes quanto aquelas dedicadas à proteção dos direitos de liberdade e propriedade, sobretudo em função do atraso das ciências jurídicas e políticas, que até a presente data não teorizaram nem desenharam um Estado social de direito comparável ao velho Estado de direito liberal e, portanto, que permitisse que os órgãos administrativos, o jogo desregrado dos privilégios e o caos normativo desembocasse na "crise de capacidade regulatória do direito", aplastando o ser humano mais fraco em sua mais própria expressão, que é a dignidade ${ }^{155}$. Comparando com a teoria do bem jurídico, os direitos humanos mais desenvolvidos em termos de garantias e exercício são os ligados ao desenvolvimento dos direitos liberais. Tanto quanto a teoria do bem jurídico, o conceito de direitos humanos é difícil de ser traduzido em melhores condições de vida à população, sobretudo aqueles não relacionados à matriz liberal (direitos políticos e de liberdade), em função de sua vacuidade, de sua extensão, pouca exequibilidade e difícil reinvindicação judicial. Servem, os direitos humanos, nas palavras de FERRAJOLI, como um limite para o "não", criando vínculos substanciais impostos à democracia política: vínculos negativos, em relação aos direitos de liberdade que nenhuma maioria pode violar, vínculos positivos, em relação aos direitos sociais, que nenhuma maioria pode deixar de satisfazer. Ao serem previstos para todos e subtraídos da disponibilidade do mercado e da

Universal Declaration of Human Rights", UNESCO Courier 30:11, Paris: United Nations Educational, Scientific, and Cultural Organization, Novembro, 1977.

${ }^{155}$ FERRAJOLI, L. Derechos y garantías. La ley del más débil, Madri: Ed. Trotta, 1999, p. 30. 
política, "atuam como fatores não somente de legitimação como também e, sobretudo, como

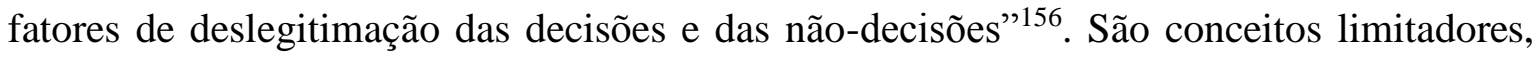
portanto, tanto quanto legitimadores da intervenção estatal, que funcionam como modelos teóricos para captar as tendências mais relevantes em determinada época e sociedade. Isso porque o direito penal, como sistema autopoiético, encontra suas referências dentro do sistema por ele criado $^{157}$, sendo irreal pretender a substituição de uma função tão potente como a do bem jurídico, por outra mais exata, que não conseguiria dar conta das transformações cada vez mais estressante que nos impõe esta Era dos Extremos.

Abre-se espaço, assim, para se considerar, com as ressalvas nossas, que os delitos jurídico-penais possam estar fundamentados em argumentos de natureza humana universal, e mais especificamente, em argumentos baseados nos direitos humanos, que acaba sendo o mesmo em diferentes culturas, principalmente nos ordenamentos liberais do direito penal $^{158}$. Concebe-se, assim, um direito penal multicultural, que retira fundamento dos direitos humanos que servem de base comum a todo o planeta e que, ao inscreverem como direitos fundamentais valores que protegem a liberdade, pluralismo, dignidade ${ }^{159} \mathrm{e}$ igualdade, valores impregnam e obrigam todo o sistema democrático.

\subsubsection{Expansionismo, Internacionalização e Ciência do direito penal}

A expansão do direito penal tratada na obra de SILVA SÁNCHEZ procura atribuir critérios racionais à proliferação de leis penais incriminadoras, novos tipos penais e flexibilização das garantias clássicas penais e processuais penais. Para o autor, o programa do direito penal mínimo, concebido por FERRAJOLI, de defesa do minimalismo, com repercussão na Escola de Frankfurt, de um direito penal básico que apenas cuidasse de condutas que atingissem ou ameaçassem atingir valores como a vida, saúde, liberdade, propriedade, com a proteção das máximas garantias, e que, agindo assim, assumisse uma

\footnotetext{
${ }^{156}$ FERRAJOLI, Derechos y garantías. La ley del más débil, op. cit., p. 24 (trad. livre).

${ }^{157}$ Por exemplo, o critério de maioridade penal, os critérios para definir os crimes de menor potencial ofensivo, ou até mesmo os limites das penas.

${ }^{158}$ FERRAJOLI, L. "La democracia constitucional", op. cit., p. 87.

${ }^{159}$ Nesse sentido, LAFER, Celso. "A reconstrução dos direitos humanos: a contribuição de Hannah Arendt", Revista de Estudos Avançados, vol.11, no.30, São Paulo, Maio/Agosto, 1997.
} 
posição de "cruzada contra o mal", é um programa desprovido da mais mínima fundamentação racional.

Assim é que o autor propõe a reinterpretação do direito penal e das garantias clássicas, ajustados aos fenômenos referidos acima, mas sobretudo o fortalecimento do direito penal econômico, das novas funções do direito penal de apoio à manutenção do sistema econômico e financeiro. Para tanto, sintetiza a teoria do direito penal das velocidades, cuja compreensão é fácil, mas de notória arbitrariedade e artificialidade. As garantias, que a assistem a todos aqueles que enfrentam um processo criminal, assistiriam somente a réus de um tipo de crime, pois as penas não seriam restritivas de liberdade, portanto não seriam necessárias as máximas garantias em vista de prejuízos menos gravosos aos direitos dos acusados. Ao justificar uma reinterpretação do direito penal tendo em vista o anseio da população por mais proteção, o autor marca esse movimento do cunho populista que pretendia afastar, porque a pena precisa ser finalmente aplicada, daí as garantias serem reduzidas, para que o direito penal recupere seu vigor. Revolver o sistema penal para sincronizar a pena com as garantias tem como ponto de partida aumentar a certeza da pena, quando o ponto de partida seria, no nosso entender, manter o sistema de garantias para os que sofrem o processo penal, qualquer que seja a pena aplicável. A expansão do direito penal não pode ocorrer para reduzir garantias em troca de torná-lo um aliado mais potente na contenção da macrocriminalidade, envolvendo-o numa racionalidade artificial que, para se firmar, perde sua alma - o fortalecimento legal do indivíduo diante do Estado.

Em relação aos novos riscos, FIGUEIREDO DIAS ${ }^{160}$ também se posiciona na direção de que o direito penal deve assegurar as condições sociais para o futuro, não se restringindo apenas aos bens jurídicos individuais, pois ao dar as costas à potencialidade danosa causada pelos riscos coletivos, estar-se-ia invertendo os princípios jurídico-penais da subsidiariedade e da ultima ratio, deixando o direito penal de tutelar bens tão grandiosos como a vida planetária, inclusive relacionados à dignidade dos indivíduos. De maneira semelhante, PALAZZO sustenta que as garantias e princípios penais fundamentais não devem ser tomados de maneira absoluta, conformando uma metafísica das garantias $^{161}$, um culto intangível e desvinculado das funções próprias do direito penal, como instrumento de

${ }^{160}$ FIGUEIREDO DIAS, Jorge de. Temas básicos da doutrina penal (...), op. cit., pp. 167 ss.

${ }^{161}$ PALAZZO, Francesco. "Principios fundamentales y opciones político-criminales en la tutela penal del ambiente en Italia". Revista Penal, $\mathrm{n}^{\circ}$ 4, 1999, pp. 68-91. 
utilidade social por meio da sanção criminal. Na manutenção do delicado equilíbrio entre racionalidade instrumental da sanção e a consagração dos direitos e garantias fundamentais dos sistemas jurídicos democráticos, propõe o autor que, ainda que se mantenham as garantias, os meios para sua afirmação e confirmação se flexibilizem, em referência à sua forma de invocação processual.

A expansão ainda é um elemento caótico, de um direito em movimento, impreciso e fluido, na expressão de DELMAS-MARTY, para a qual um modelo ainda não existe, considerando modelos teóricos como o direito penal da intervenção ou o direito penal das duas velocidades. Uma das formas de expressão do expansionismo, que nos cabe, é a internacionalização do direito penal, que representa uma forma de articulação das categorias criminais e repressivas do direito, com presença cada vez mais marcante em termos concretos, por meio do direito penal internacional, nas formas de articular a repressão criminal em âmbito internacional, mas sobretudo os fundamentos em que ele se baseia. Assim, a doutrina encontra um campo novo para a harmonização do direito penal, com base em tratados internacionais, como no âmbito da União Europeia, para o estabelecimento de normas quadro mínimas de definição de infrações penais e sanções cujo combate compartilhado faça sentido.

A expansão do direito penal, conforme vimos, não é apenas uma expansão de delitos ou de bens jurídicos, a desvirtuar a proteção conferida pelo direito penal. Nota-se, sim, uma expansão causada pela redução de princípios, de condições para a imputação objetiva e subjetiva, conformando uma área do direito em mutação, que não se conforma mais com o "papel tradicional da busca justa e exemplar pela responsabilidade individual" ${ }^{\prime 162}$. Conquanto até agora o direito penal seja concebido como uma ciência nacional ${ }^{163}$, como expressão do poder de soberania sobre seus cidadãos, novas perspectivas e rearranjos internacionais podem alterar esta concepção, catapultados sobretudo pela afirmação institucional dos direitos humanos. HIRSCH, seguindo os trabalhos em direito

\footnotetext{
${ }^{162}$ PRITTWITZ, C. "A função do direito penal na sociedade globalizada do risco - defesa de um papel necessariamente modesto (...)", op. cit., p. 66.

${ }^{163}$ Em igual sentido, FIGUEIREDO DIAS, Jorge de, Direito Penal - Parte Geral, Ed. Revista dos Tribunais e Coimbra Editora, 2007, pp. 10 ss. "O direito penal é ainda hoje essencialmente direito intra-estatal, que encontra a sua fonte formal e orgânica na produção legislativa estadual e é aplicado por órgãos nacionais. Todavia, a partir da última década do séc. XX assistiu-se a um prodigioso incremento da relevância do direito internacional no direito penal" (grifos no original).
} 
comparado promovidos por JESCHECK, propõe reflexões sobre um modelo de direito penal supranacional, indicando que Estados com pretensões hegemônicas tentarão conduzir esse processo de acordo com o estado da arte de sua ciência penal. Mas que ao possuírem um grau mais adiantado em termos de desenvolvimento do direito penal, faria com que o direito penal supranacional permanecesse abaixo do nível alcançado por diversos Estados ${ }^{164}$. Vêse, a partir daí, a dificuldade de chegar a um consenso em torno do que poderia se formar a partir de sistemas de direito tão diferentes entre si. Por mais ordinária que seja a constatação de que os problemas relacionados ao crime sejam de captação comum em diversas sociedades do mundo, a forma de analisá-lo e tratá-lo encontra-se em estágios distintos em termos de evolução nacional da ciência penal em cada país.

Franz VON LISZT afirmou há mais de cem anos que "a ciência do direito penal" como "a exposição dos elementos do conceito de delito (...) é necessariamente internacional" 165 , de alguma forma validando o esforço empreendido de refletir sobre o campo penal em termos comparados. Assim, propõe-se identificar na construção de uma ciência penal universal sobre quais elementos ela se funda, quais as questões que busca resolver e como atinge seus resultados. Antes de enfrentar essa tarefa propriamente dita, HIRSH traz a discussão sobre se essa ciência seria fundamentalmente normativista ou ontológica, adiantando que sendo normativista, ela retornaria ao Estado, sem poder lançarse para esse novo plano internacional. Por outro lado, reconhece que há determinadas "propriedades do ser" do direito penal que devem ser observadas pelo legislador, sendo a

${ }^{164}$ HIRSCH, H. J. "Internacionalización del derecho penal...”, op. cit., p. 405-6. Afirma HIRSCH que é fácil notar que os teóricos do direito penal do mundo se dedicam a resolver os mesmos problemas quando se trata dos pressupostos gerais do fato punível, por exemplo, especificamente a respeito do dolo, da imprudência, ressaltando a importância de associações como a AIDP (Associação Internacional de Direito Penal) na discussão de problemas e intercâmbio científico supranacional.

${ }^{165}$ Das Strafrecht der Staaten Europas, 1984, p. XXIV, apud HIRSCH, H. J. "Internacionalización del derecho penal...”, op. cit., p. 405. Apesar deste pensamento, a tendência predominante entre os penalistas alemães é contra um direito penal europeu unitário, v. HUSARBO, R.J.; STRANDBAKKEN, A. Harmonization of Criminal Law in Europe, Oxford: Intersentia, 2005. Jorge de FIGUEIREDO DIAS reconhece que ainda que inexista um direito penal comunitário, supranacional, refletindo sobre a Decisão-quadro 2003/80/JAI, de 27.01.2003, sob o fundamento de que medidas de proteção penal do ambiente poderiam ter sido validamente adotadas com base no art. 175 do Tratado da Comunidade Europeia, admite expressamente que a Comunidade Europeia tem o poder de obrigar os Estados Membros a adotarem normas de índole penal "quando a aplicação das sanções penais efetivas, proporcionadas e dissuasivas pelas autoridades nacionais competentes constitua uma medida indispensável para lutar contra os atentados graves" aos interesses que lhes são confiados. Ainda que esse acórdão não permitisse afirmar a criação de obrigação automática aos cidadãos e aos Estados Membros, é seguro afirmar o exercício pela Comunidade Europeia de um ius puniendi negativo, pois a partir da prevalência do direito comunitário sobre o nacional e do princípio da unidade da ordem jurídica, “o legislador nacional não poderá qualificar como penalmente ilícitas condutas exigidas ou autorizadas pelo direito comunitário", Direito Penal - Parte Geral, Ed. Revista dos Tribunais e Coimbra Editora, 2007, pp. 12 e 13 . 
tarefa dessa ciência mostrar tais estruturas e deduzir delas as consequências relevantes, voltando-se às estruturas das matérias de regulação e do direito, conforme WELZEL ${ }^{166}$ já apresentava. Há grande semelhança nas questões a serem abordadas pela parte geral do direito penal em todo o mundo e, segundo HIRSH, é possível uma discussão universal sobre questões como a relação de imputação entre a ação contrária ao dever de cuidado e o resultado nos crimes culposos por imprudência, por exemplo, quando se inicia a tentativa, de forma que a solução possa ser satisfatória de modo genérico em distintos sistemas jurídicos. É o que FLETCHER propôs quando escreveu sobre uma gramática universal da ciência penal ${ }^{167}$, embora severas críticas sejam feitas à construção dogmática da common law, pois, segundo o autor, os teóricos dessa tradição jurídica aproveitaram-se da necessidade que há do conhecimento da língua inglesa entre os pesquisadores de direito e que por conta do conhecimento da língua, forçou-se a popularização de seu sistema jurídico ${ }^{168}$. É também comum o sentimento de que o common law tenha determinado, quase exclusivamente, a evolução da jurisprudência e das codificações de direito penal internacional ${ }^{169}$, inclusive pela importância do inglês como língua franca também no diálogo intercultural.

Também chegou-se a afirmar que uma ciência penal universal deixaria intacta a própria ciência penal fundada no direito nacional, pois para KÜHL não existe uma ciência penal alemã, japonesa, italiana, mas apenas um âmbito central de investigação e uma concreção teórica que seja total ou parcialmente correta ou incorreta de acordo com os padrões científicos gerais ${ }^{170}$. Construindo um patrimônio jurídico que seria da humanidade, HIRSH também identifica que as normas de um direito penal supranacional estariam imune às "canetadas" do legislador nacional, citando a famosa frase de KIRCHMANN de que "três palavras retificadoras do legislador e bibliotecas inteiras se convertem em papel de

166 WELZEL, Hans. El nuevo sistema del derecho penal; una introducción a la doctrina de la acción finalista; Madrid; tradução em espanhol de José Cerezo Mir; Ed. 1964.

${ }^{167}$ FLETCHER, Georg. The gramar of Criminal Law, vol. 1. Foundations: Oxford University Press, 2007.

${ }^{168}$ Essa crítica será retomada quando tratarmos da construção do direito penal internacional e a influência do sistema da common law em seus institutos. Desde já, ARROYO ZAPATERO, Luís. "A harmonização internacional do direito penal (...)", op. cit., p. 76.

${ }^{169}$ AMBOS, Kai. A parte geral do direito penal internacional: bases para uma elaboração dogmática (Trad. Carlos Eduardo Adriano Japiassú e Daniel Andrés Raizman). São Paulo: Ed. Revista dos Tribunais, 2008, pp. 49-51.

${ }^{170}$ Festschrift für Spendel, p. 43, 58, apud HIRSCH, H.J. "Internacionalización del derecho penal (...)”, op. cit., pp. 411-2. 
rascunho"171. Esse esforço produziria um conhecimento supranacional com características normativas de validade com caráter geral, num esforço máximo para apontar os pressupostos de todo fato punível e seus requisitos, para distintos ordenamentos jurídicos, simultaneamente, e derivado do mesmo poder legiferante.

Apesar de não estarmos institucionalmente prontos para avançar num projeto de direito penal supranacional, pode-se concluir que junto à ciência penal nacional já existe uma universal sendo construída, cada vez mais apartada do direito comparado e mais fortalecida pela tendência da europeização e da globalização ${ }^{172}$. Abrem-se espaços para discussões cada vez mais propositivas que buscam refúgio nos direitos humanos ${ }^{173}$ para recepcionar essa tendência expansiva do direito penal no âmbito internacional.

Faz-se necessário avaliarmos as condições de desenvolvimento do direito penal internacional e afirmação de seus institutos jurídicos que irão fornecer importantes elementos em bases concretas para refletirmos sobre os efeitos da tutela penal dos direitos humanos e os reflexos desta tendência expansiva na dogmática penal.

${ }^{171}$ Entendemos, contrariamente, que o fato de ter validade universal não aproxima a ciência penal da ciência natural, pois o homem continua por trás da elaboração da norma penal.

172 Nesses termos, HIRSCH, "Internacionalización del derecho penal (...)”, op. cit., conclusões.

173 ARROYO ZAPATERO, L. "A harmonização internacional do direito penal: ideias e processos”, op. cit., pp. 49-76. 


\section{CAPÍTULO 2 - DIREITO PENAL INTERNACIONAL - FORMAÇÃO}

\subsection{Conceito}

Dentro do caminho desenhado para uma avaliação crítica do direito penal internacional e sua relação com a expansão do direito penal, propomos uma primeira reflexão a respeito da construção da sua dogmática e do processo evolutivo de seu conceito. Se hoje entendemos o direito penal internacional como a área do direito que estuda a aplicação das disposições com conteúdo penal emanadas da comunidade internacional com o fim de tutelar seus interesses fundamentais, às quais estariam submetidos diretamente os cidadãos de todas as nações e que seriam aplicadas por órgãos internacionais ${ }^{174}$, este conceito foi sendo lapidado através das décadas.

Atribui-se a paternidade da expressão direito penal internacional a BENTHAM, referida por VON LISZT, para designar o conjunto de regras de direito interno relativas aos limites da aplicação da lei penal no espaço ${ }^{175}$, incluindo temas relativos à competência de jurisdição, lei penal aplicável, cooperação judicial e eficácia das sentenças estrangeiras. Nota-se, portanto, que segundo esta definição, não se trata nem de normas penais materiais, nem de direito internacional, pois refere-se a situações reguladas pelo direito interno a partir da resolução do conflito aparente de normas. Outros autores também referem-se ao direito penal internacional como o ramo do direito dirigido a resolver os conflitos decorrentes da aplicação da lei penal no espaço, especialmente relativas à extradição e asilo, como BUSTOS RAMÍREZ e HORMAZÁBAL MALARÉE ${ }^{176}$, e também com BACIGALUPO ZAPATER, que chegou a afirmar que "o direito penal internacional é produto da soberania de cada Estado e estende a aplicação das normas nacionais de direito penal precisamente até onde se

\footnotetext{
${ }^{174}$ Adaptado do conceito trazido por GIL GIL, Alice, Derecho Penal Internacional, p. 24. Para a autora, tratase das disposições emanadas da comunidade internacional com o fim de tutelar seus interesses fundamentais, às quais estariam submetidos diretamente os cidadãos de todas as nações e que seriam aplicados por órgãos internacionais. Acrescentamos que trata-se de disposições com conteúdo penal, para diferenciar de outras de conteúdo de direitos humanos, ou ambientais, etc. Ou como CEREZO MIR, J. Curso de derecho penal español, vol. I, $6^{\text {a }}$ ed., Madri, 2004, p. 258, referindo-se ao conjunto de normas dirigidas a tutelar interesses fundamentais da comunidade internacional.

175 DÍEZ SÁNCHEZ, J.J. El Derecho penal internacional (ámbito espacial de la ley penal). Madri: Colex, 1990, p. 15

${ }^{176}$ BUSTOS RAMÍREZ, J.; HORMAZÁBAL MALARÉE, H. Lecciones de derecho penal, vol. 1. Madri: Ed. Trotta, 1997, p. 116
} 
estende sua soberania, ou seja, até onde os demais Estados soberanos o consentem"177. Ocorre que esta definição, embora não tão distante quanto aquela com que trabalhamos, é válida na parte formativa da construção dos tribunais e adesão ao seu tratado constitutivo e competência, mas não chega a evoluir até o estágio de existência de órgãos autônomos e jurisdição universal.

QUINTANO RIPOLLÉS dá um passo importante quando expande a órbita de interesse de proteção do direito penal internacional ao identificar a existência de crimes contra interesses ou bens internacionais previstas por ordenamentos estatais internos, incluindo os crimes contra o direito das gentes ${ }^{178}$. Ou seja, refere-se a crimes previstos na ordem interna mas que visam à proteção de bens internacionalizados em função do bem jurídico protegido. Reconhece-se, assim, uma dupla incidência da conduta: a relevância internacional pelo objeto, mas interna em função do sujeito, ou seja, súdito de alguma soberania estatal.

A dificuldade em se encontrar as definições dos crimes de direito penal internacional nas obras de direito internacional é a de que as condutas clássicas objeto do direito internacional dizem respeito ao comportamento dos Estados na órbita internacional. Assim é que, para Claude LOMBOIS ${ }^{179}$, trata-se da "disciplina jurídica tendo por objeto as relações entre o direito de punir e a soberania dos Estados", ou seja, muito mais afeita a temas de cooperação judiciária, extradição, aplicação das leis penais no espaço, do que propriamente de conteúdo material penal. Essa amplitude também é reconhecida por DONNEDIEU DE VABRES, que considera o direito penal internacional como a ciência que determina a competência das jurisdições penais do Estado em confronto com as jurisdições estrangeiras ${ }^{180}$, ou seja, a repercussão extraterritorial do próprio direito penal interno.

Para se firmar, o direito penal internacional precisou consolidar no plano internacional a responsabilidade penal do indivíduo, por meio de suas superações: o

\footnotetext{
${ }^{177}$ BACIGALUPO ZAPATER, E. "Jurisdicción penal nacional y violaciones massivas de derechos humanos cometidas em el extrangero". In: El derecho Penal Internacional. Cuadernos de Derecho Judicial, Madri: CGPJ, 2001, p. 212 (trad. livre).

${ }^{178}$ QUINTANO RIPOLLÉS, A. Tratado de derecho penal internacional. Parte General I, 1956, pp. 12 ss.

${ }^{179}$ LOMBOIS, Claude. Droit penal international. $2^{\mathrm{a}}$ ed., Dalloz, Paris, 1979, pp. 13 ss.

180 DONNEDIEU DE VABRES, Henri. Les Principes Modernes du Droit Pénal International, Paris: Panthéon-Assas, 2004, p. 3.
} 
reconhecimento do indivíduo como sujeito de direitos no plano internacional, superando a posição defensiva dos Estados diante de qualquer possível violação de sua soberania, e o reconhecimento do indivíduo no polo ativo do cometimento de crimes, por meio da responsabilidade penal do indivíduo ${ }^{181}$ pelos crimes na órbita internacional. Esse posicionamento foi defendido por LAUTERPACHT, um dos principais e mais influentes internacionalistas do século passado, crítico do instituto da soberania e da figura dos Estados como únicos sujeitos do direito internacional, pois, como em todo o direito, os indivíduos são os sujeitos últimos dos direitos e obrigações relevantes ${ }^{182}$.

Também faz parte da evolução do conceito de direito penal internacional sua contraposição ao direito internacional penal a ser aprofundado no subcapítulo seguinte. Se direito penal internacional refere-se à manifestação internacional do direito penal interno, o direito internacional penal refere-se aos aspectos penais do direito internacional, abrangendo a prática internacional, por meio do consenso entre os Estados, de incriminação de determinadas condutas, inclusive pela via consuetudinária, como temas que tratam dos crimes de guerra, regulamentação em geral dos conflitos armados, etc. É dentro deste segmento que se inserem as Convenções de Genebra de 1864, que criou a Cruz Vermelha, e as de Haia, de 1899 e 1907, que regularam os conflitos armados.

\subsection{Rumo a um consenso}

Com os Códigos Penais da França e da Alemanha, no séc. XIX, admitindo-se a aplicação extraterritorial das normas penais, cuja maior consequência é a disciplina jurídica da extradição, os Estados passaram a considerar os efeitos internacionais de suas normas

\footnotetext{
${ }^{181}$ WERLE, Gerhard. Tratado de derecho penal internacional, p. 43.

${ }^{182}$ Conforme KOSKENNIEMI, os escritos de Lauterpacht representam um novo direcionamento para o direito internacional pelos ataques empreendidos contra o estatismo das relações internacionais, mas também pelo conteúdo e poder que pretende conferir à teoria dos direitos humanos. Segundo citado por KOSKENNIEMI, "it is the current personification of the State, which artificially distinguishes between the association and the members comprisigin it, that has been a contributing factor in suggesting that anarchical principle of legal and moral responsibility (...). The adoption of the principle of international criminal responsibility of the individuals to whom liability for the criminal act can be feasibly be traced”. Segundo KOSKENNIEMI, há indícios de que Lauterpacht tenha sido o doutrinador de direito internacional a que faz referência o procurador do Tribunal de Nuremberg, Robert H. Jackson, na inclusão da denominação "crimes contra a humanidade" no Estatuto do Tribunal Internacional Militar - Nuremberg. KOSKENNIEMI, Martii. "Hersh Lauterpacht and the Development of International Criminal Law”, Journal of International Criminal Justice, 2, 2004, pp. 811, 813, 814.
} 
penais, ganhando relevo a questão da aplicação espacial da norma penal, inclusive sob o aspecto do possível conflito de normas. Ao dar consequência internacional ao direito penal interno, por meio dos reflexos nas jurisdições estrangeiras, estamos tratando de um aspecto material de aplicação do direito interno no espaço e sistemas de colaboração interestatal para julgamento pelo cometimento de crimes contra a ordem interna estatal ${ }^{183}$. Certamente, não estamos tratando deste direito interno, mas da transformação que começa a se operar para a formação de um concerto internacional que busca criar regras internacionais, com conteúdo internacional e penal e que incriminam certas condutas.

Apesar de traços diferenciadores, as denominações de direito penal internacional ou direito internacional penal foram utilizadas de forma indiferente para fazer referência tanto ao conjunto de normas internacionais referentes a delitos, consequências de delitos, tribunais penais internacionais e processo penal, como a área do direito penal que regula os problemas de competência nos conflitos penais que dizem respeito a vários Estados ${ }^{184}$. Nessa mesma linha, nos dizeres de FIGUEIREDO DIAS ${ }^{185}$, a distinção entre direito penal internacional e direito internacional penal, vai perdendo o sentido. Segundo o autor, o direito penal internacional dizia respeito às disposições dos códigos penais que dispunham sobre as regras e critérios de aplicação da lei penal no espaço, enquanto o direito internacional penal cuidaria da aplicação e diplomacia em torno dos tratados com conteúdo penal, especialmente pela vinculação de Estados a instrumentos internacionais ${ }^{186}$. Por fim, afirma FIGUEIREDO DIAS:

\footnotetext{
"Tornou-se hoje corrente, de todo o modo - sobretudo depois da criação do Tribunal Penal Internacional pelo Tratado de Roma - usar a expressão direito penal internacional mesmo para nomear aquilo que tradicionalmente se designava por direito internacional penal, tendo por isso a distinção formal praticamente perdido o sentido indicativo que lhe presidia" ${ }^{187}$.
}

\footnotetext{
${ }^{183}$ BASSIOUNI, M. Cherrif. Introduction to International Criminal Law, $2^{\text {a }}$ edição, Brill: Nijhoff, 2012 , p. 7. ${ }^{184}$ V. ANDRÉS DOMINGUES, Derecho Penal Internacional, Tirant monografias, 2006, p. 14.

${ }^{185}$ FIGUEIREDO DIAS, Jorge de. Direito Penal - Parte Geral, T. 1. Coimbra: Ed. Coimbra, 2007, p. 208.

${ }^{186}$ Em igual sentido, ANDRÉS DOMINGUES, A.C., Derecho Penal Internacional, Tirant monografias, p. 167, para quem o conceito de direito penal internacional deve englobar tanto os temas originais de direito penal internacional quanto os temas modernos do direito internacional penal. Para maiores discussões sobre a nomenclatura, ver SZUREK, S., "Historique de la formation du droit international pénal", In ::ASCENSIO, H. ; DECAUX, E. e PELLET, A. (org), op. cit., pp. 8 ss;

${ }^{187}$ FIGUEIREDO DIAS, Jorge de. Direito Penal - Parte Geral, p. 208. Igualmente, JAPIASSU avalia que essa discussão atualmente apenas tem valor histórico e sentido metodológico. JAPIASSU, Carlos Eduardo Adriano. O Tribunal Penal Internacional - a internacionalização do direito penal. Rio de Janeiro: Lumen Juris, 2004, p 9.
} 
Diversos autores de forma semelhante enfatizam a diferença entre direito penal internacional e direito internacional penal ${ }^{188}$ no mesmo sentido apontado por FIGUEIREDO DIAS acima, mas reconhecemos a tendência apontada por ele na citação feita acima, sobretudo analisando a doutrina produzida em língua inglesa na qual o termo international criminal law é vasta para se referir ao fenômeno tratado neste trabalho. Talvez por se entender que o que era anteriormente direito penal internacional é, na verdade, expressão do próprio direito penal interno, e que o international criminal law é o termo que invade a produção científica sobre essa área, passamos a aceitar o uso daquela expressão para se dizer, na realidade e substancialmente, international criminal law e a instituição principal a conduzir o avanço da disciplina se chama Tribunal Penal Internacional.

\subsection{Dificuldades de harmonização}

CASSESE $^{189}$ define o direito penal internacional como o corpo de regras internacionais voltadas a condenar certas categorias ou condutas (crimes de guerra, crimes contra a humanidade, genocídio, tortura, agressão, terrorismo) e tornar os indivíduos que pratiquem estas condutas criminalmente responsáveis. Além disso, o direito penal internacional abrangeria as normas procedimentais diante dos tribunais para o processamento e julgamento dos acusados destes crimes. Desta forma, as obrigações de obediência e de atribuição de responsabilidade são aplicáveis diretamente, sem a intermediação de um Estado.

O direito penal internacional é um ramo reconhecidamente híbrido, filho de um casamento tripartite entre o direito internacional dos direitos humanos, o direito internacional humanitário (primo do jus in bello) e o direito penal nacional. A dificuldade e o debate central na consolidação dessa nova área é precisamente a diferente orientação de cada um desses ramos jurídicos e uma perspectiva de conciliação destas diferenças, às vezes

188 V. ZAFFARONI, Eugenio Raúl; ALAGIA, Alejandro; SLOKAR, Alejandro. Derecho Penal: Parte General, $2^{\mathrm{a}}$ ed., Buenos Aires: Ediar, 2002, p. 195, e DOTTI, René Ariel. Curso de Direito Penal - Parte Geral, $2^{\text {a }}$ ed., Rio de Janeiro: Ed. Forense, 2004,p. 109.

${ }^{189}$ CASSESE, Antonio. International Criminal Law. Oxford: Oxford University Press. 2a . Ed., 2008, p. 3. 
improvável, sobretudo à custa do direito penal de ultima ratio. Enquanto um dos primados centrais do direito penal é a elaboração de regras jurídicas precisas, o propósito dos instrumentos de direito internacional dos direitos humanos é sua invocação especialmente para justificar interpretações extensivas de crimes de modo a assegurar que "se um dano é reconhecido e remediado, ao longo do tempo, há a maior e progressiva realização do respeito pela dignidade humana e liberdade" ${ }^{\$ 190}$, uma forma de buscar fazer justiça longe do rigor da norma e da ciência penal, ou de outra forma, justiça substantiva ${ }^{191}$.

Principalmente a partir de meados dos anos 1990, o direito penal internacional experimentou um grande impulso, tanto por meio da criação de instituições quanto pela articulação normativa, liderado principalmente pelos internacionalistas, com experiência e conhecimentos sobretudo na área dos direitos humanos e direito humanitário. Visto como uma realização dessas áreas, com o primeiro esboço prático da criação de um tribunal internacional de caráter permanente para a punição dos perpetradores das violências mais graves contra os direitos humanos, rapidamente esses especialistas passaram a adotar e a trabalhar conceitos do direito penal, mas a partir de uma base formativa prévia e consolidada: a proteção internacional dos direitos humanos contra as graves violações, ou, "por meio das lentes dos pressupostos normativos de seus originais domínios de expertise" $" 192$. As consequências não foram pequenas, o que pode ser demonstrado pela facilidade de adaptação à norma internacional direitos já previstos em tratados de direitos humanos, como os direitos ao devido processo legal, já enunciados no Pacto Internacional dos Direitos Civis e Políticos

\footnotetext{
${ }^{190}$ Cf. DANNER e MARTINEZ. "Guilty associations: joint criminal enterprise, command of responsibility, and the development of international criminal law", 93 California Law Review, 2005, p. 75 (trad. livre).

191 Buscando justificar a aplicação da justiça substantiva a despeito das formalidades jurídico-criminais: "Some criminal defense lawyers from national systems may be scandalized at the ease with which the [international criminal law] judges have enlarged the definitions of crimes and the general principles of criminal responsibility. But this writer is not overly troubled by the point, because whether or not criminal behavior falls within the scope of international prosecution by the 'ad hoc' Tribunals is fundamentally a jurisdictional issue. Even if we suppose, for the sake of argument, and as many believed before the Tadic Jurisdiction Decision, there was no individual criminal liability at international law in internal armed conflict, the underlying acts of killing, torture and rape remained crimes under general principles of law. An offender can plead that the Tribunal is without jurisdiction, based on a certain interpretation of the subject matter provisions, but it cannot be argued that he or she did not know it was wrong". SHABAS, William. "Interpreting the Statutes of the Ad Hoc Tribunals", In: VOHRAH, L. C. (ed.). Man's Inhumanity to Man: Essays on International Law in Honor of Antonio Cassese, 2003, p. 887.

${ }^{192}$ ROBINSON, Darryl, no original: "through the lens of the normative assumptions from their native domains of expertise". "The identity crisis of international criminal law". Leiden Journal of International Law, 23, 2008, p. 928 .
} 
(1966), mas não em relação a princípios como a culpabilidade, proporcionalidade, legalidade em suas diversas dimensões ${ }^{193}$, temas mais identificados com a ciência penal pura.

Algumas modulações que ocorrem nesse momento formativo de uma nova área são necessárias, considerando a máxima incidência de um poder público, ainda que de direito internacional, na liberdade individual, isso porque, mais do que tratar os acusados como objetos de uma lição a ser aplicada, há que buscar tratá-los como meio de realização da justiça, aplicando-se diversas restrições principiológicas e garantindo o gozo de todos os direitos gerais dos acusados nos processos. A transposição das normas que determinam aos Estados que efetivem as punições por violações aos direitos humanos e ao direito humanitário para normas penais de aplicação direta deve ser visto com cuidados e ponderações. Para tanto, pode-se citar a norma do TPI, art. 28, a respeito da responsabilidade por comando dos superiores hierárquicos, já vertida em outros diplomas de direito penal internacional (Estatuto do TPII e do TPIR, arts. 7.3 e 6.3, respectivamente), veiculando um critério de culpabilidade no âmbito penal, mas cujas origens foram transplantadas do direito humanitário, conforme originalmente previsto nos arts. 86.2 e 87.3 do Protocolo Adicional I à Convenção de Genebra, de $1977^{194}$. Assim, uma integração artificial de uma norma do direito humanitário para o direito penal internacional permitiu que o TPI considere crime, tanto a realização das condutas típicas de um crime contra a humanidade quanto o fato de o comandante não evitar que o crime ocorra e, ainda mais grave, falhar em punir sua ocorrência. O equívoco do diploma é tratar sob a mesma conduta típica ações completamente diferentes e que não dizem respeito, da mesma forma (evitar o crime e não punir sua

\footnotetext{
${ }^{193}$ Certamente que a influência dos direitos humanos e direito humanitário não são apenas negativas, mas para uma abordagem crítica, que saia do lugar comum, esse tipo de colocação é relevante.

${ }^{194}$ Conforme os artigos, reconhece-se a responsabilidade do comandante pela ação de seus subordinados, mas não se equipara a responsabilidade deles pela ação dos subordinados, nem se considera a responsabilidade penal como a única sanção. Art. 86.2: "O facto de uma infração às Convenções ou ao presente Protocolo ter sido cometida por um subordinado não isenta os seus superiores da sua responsabilidade penal ou disciplinar, consoante o caso, se sabiam ou possuíam informações que permitissem concluir, nas circunstâncias do momento, que aquele subordinado cometia ou ia cometer tal infracção e não haviam tomado todas as medidas praticamente possíveis dentro dos seus poderes para impedir ou reprimir essa infracção." e art. 83.3: "As Altas Partes Contratantes e as Partes do conflito devem exigir que qualquer comandante, que tiver conhecimento de que subordinados seus ou outras pessoas sob a sua autoridade vão cometer ou cometeram uma infraç̧ão às Convenções ou ao presente Protocolo, tome as medidas necessárias para impedir tais violações às Convenções ou ao presente Protocolo e que, oportunamente, tome a iniciativa de uma ação disciplinar ou penal contra os autores das violações".
} 
execução) com o cometimento do crime. Ainda, o direito humanitário permitia a punição disciplinar das falhas dos comandantes - o que o direito penal internacional pune como o crime em si.

\subsection{Afirmação Histórica dos Tribunais Militares, Penais Internacionais Ad Hoc e Mistos}

O processo de afirmação histórica do direito penal internacional passa pelo projeto de criação ou do fortalecimento de uma jurisdição universal, com a consolidação do Tribunal Penal Internacional ou da aplicação de normas internas quando estas protejam os mais altos valores de sustentação da comunidade internacional ${ }^{195}$. Com esse objetivo, abordamos os tribunais havidos com o propósito de aplicação de penas individuais por crimes internacionais praticados, adotando como marco inicial o Tribunal Militar Internacional, conhecido como Tribunal de Nuremberg, e o Tribunal Militar para o Extremo Oriente, conhecido como Tribunal de Tóquio.

\subsubsection{Tribunais Internacionais}

\section{a) Primeiros Antecedentes e Nuremberg: Tribunal Militar Internacional}

Atribui-se ao Projeto Moynier, de Gustave Moynier, de 1872 a primeira iniciativa de se criar uma instância judicial internacional dedicada à aplicação direta de sanção aos indivíduos que violarem as normas de direito internacional humanitário, sob o impulso da incipiente Cruz Vermelha. A Convenção de Genebra de 1864 sobre o tratamento que deveria ser dado aos soldados feridos em campanha não previa sanções em caso de violações às suas disposições, deixando aos Estados decidirem por si a implementação ou

195 Para uma abordagem mais extensa do conceito de tribunais internacionais, v. MENEZES, Wagner. Tribunais Internacionais. Jurisdição e Competência. Ed. Saraiva: São Paulo, 2013, pp. 145 ss. 
não de suas regras ${ }^{196}$. O projeto de Gustave Moynier ${ }^{197}$ previa corrigir essa falha e embora sua doutrinária não tenha sido colocada em prática no século XIX, representara importante contribuição para o conceito de crime internacional e modelos de justiça penal internacional $^{198}$.

$\mathrm{Na}$ concepção que adotamos, o direito penal internacional apenas se consolida após a II Guerra Mundial, por meio dos julgamentos se Nuremberg e de Tóquio, com contornos, atribuições e resultados próprios. Ainda que mesmo antes já houvesse normas e documentos que tratassem da matéria penal internacional, inclusive no Tratado de Versalhes $^{199}$ após a I Guerra Mundial ${ }^{200}$, os julgamentos referidos desencadearam um importante movimento que refletisse sobre a repercussão internacional, pela gravidade das condutas praticadas por países, ou seus nacionais, na comunidade internacional, e de que ela poderia e deveria reagir dentro de um novo marco jurídico.

196 Àquela altura, raros eram os tratados que continham sanções ao seu descumprimento, como a Convenção de Mainz, de 31.03.1831, sobre a navegação no Reno, e o tratado entre Suíça e França sobre propriedade intelectual, permitindo-se aos tribunais nacionais aplicar penas por descumprimento às suas disposições. Entretanto, já havia o conceito de jurisdição universal, concebida inicialmente em relação à pirataria (leading case Estados Unidos vs. Smith, de 1820, no qual a Suprema Corte considerou os piratas como inimigos da humanidade (hostis humani generis), puníveis nos tribunais de todas as nações. JARDIM, Tarciso dal Maso. “A contribuição da justiça internacional penal: formação de paradigmas”. Revista Anistia, vol. 9, de 9 de outubro de 2014, p. 157.

${ }^{197}$ MOYNIER, Gustav. Note sur la crèation d'une institution judiciaire internationale propre à prevenir et a réprimer les infrations à la Convention de Genève, Soulier et Wirth, Genebra, 1872. PETIT GABRIEL, E. "La propuesta de un tribunal penal internacional de Gustave Moynier, un proyeto antíguo recientemente rescatado". In:CARRILLO SALCEDO, Juan Antonio (Coord.). La criminalización de la barbárie: la CPI”. Consejo General del Poder Judicial: Madri, 2000, pp. 29-87.

198 Sobre o contexto histórico e os debates em torno das primeiras ideias sobre punições internacionais, referimo-nos ao artigo de JARDIM, Tarciso dal Maso. "A contribuição da justiça internacional penal: formação de paradigmas", op. cit., pp. 150-186, e sobre essa última afirmação, especificamente p. 167.

199 O Tratado de Paz de Versalhes, de 28.06.1919, declara que "as potências aliadas e associadas acusam publicamente Guilherme II de Hohenzollern, ex-imperador da Alemanha, pela ofensa suprema contra a moral internacional e a santidade dos tratados", assim, deveria ser estabelecido um tribunal penal internacional, podendo, inclusive, os aliados julgarem por seus próprios tribunais militares os "acusados de terem cometido atos contrários às leis e aos costumes de guerra", além de poderem, para tanto, obrigar o governo alemão a extraditar os criminosos de guerra e a prestar assistência judicial (arts. 227.2, 228.1, 229.1, 228.2 e 230 do Tratado de Versalhes). Os julgamentos jamais ocorreram, sobretudo pela firme negativa do governo alemão de extraditar as pessoas indicadas para os tribunais militares dos aliados. A Alemanha concordou em realizar os julgamentos, por meio dos conhecidos Tribunais de Leipzig, mas serviu mais como intento de aplacar a vontade dos aliados do que de punir os criminosos de guerra.

${ }^{200}$ BASSIOUNI, avaliando os antecedentes, cita inclusive os textos de Sun-Tzu, autor do A arte da guerra, o general chinês que faz análises políticas além de militares, recomenda o tratamento humano dos civis, feridos e prisioneiros de guerra, assim como das instituições religiosas do país. Cf. Introduction to (...), op. cit., p. 78. 
As bases para a consolidação do direito penal internacional, como o entendemos hoje, foram lançadas na Declaração de Moscou, 1943, pelos três líderes aliados, Roosevelt, Churchill e Stálin, na qual se lia:

\begin{abstract}
"Que eles reconhecem a necessidade do estabelecimento o quanto antes possível de uma organização internacional geral, baseada no princípio da igualdade de soberania de todos os estados que abraçam a paz, e aberto a adesões por quaisquer outros estados, grandes ou pequenos, para a manutenção da paz internacional e da segurança"201.
\end{abstract}

De acordo com o quanto dito, as potências aliadas, baseadas no interesse das 32 Nações Unidas, declaram, conforme segue:

\begin{abstract}
"No momento de conferir qualquer armistício a qualquer governo que possa ser estabelecido na Alemanha, aqueles oficiais alemães e homens e membros do partido nazista que tenham sido responsáveis por ou sido considerado uma parte concordante com as atrocidades mencionadas, massacres e execuções, serão enviados de volta aos países nos quais suas dívidas abomináveis foram perpetradas com o objetivo de que possam ser julgados e punidos de acordo com as leis destes países libertados e de governos livres, que serão lá erigidos (...). A declaração acima é feita sem prejuízo dos casos dos criminosos alemães cujos crimes não tenham localização geográfica particular e que serão punidos por uma decisão conjunta dos governos aliados." 202
\end{abstract}

Assim, os governos aliados comprometiam-se a perseguir os criminosos de guerra até "os últimos rincões da Terra e entregá-los aos seus acusadores para que a justiça fosse feita", visto que os crimes cometidos, como dito na Declaração, não tinham uma localização geográfica específica, recaindo sobre representantes da comunidade internacional, a obrigação de punir.

Finalmente, três anos após a Declaração de Moscou, em 1946, por meio do Acordo de Londres, criou-se o Tribunal de Nuremberg, o primeiro tribunal internacional que levasse a cabo o julgamento das atrocidades praticadas pelos nazistas. Ainda que inexistisse uma tipificação internacional dos crimes a julgar, estes deveriam ser julgados com base nos

${ }^{201}$ Item 4 da Declaração de Moscou, de 30 de outubro de 1943 (trad. livre).

${ }^{202}$ Itens 3 e 4 da declaração sobre as atrocidades alemãs, Declaração de Moscou de 30 de outubro de 1943 (trad. livre). 
princípios universais que defende os valores mais transcendentais do ser humano como tal ${ }^{203}$. O Estatuto do Tribunal de Nuremberg, em seu art. $6^{\circ}$, distinguia os crimes contra a paz, crimes de guerra e crimes contra a humanidade, com importantes consequências para o direito internacional: a criação de responsabilidade individual (a despeito da obediência a leis nacionais), a proteção da população civil (a despeito da soberania estatal), dizendo-se que o Estatuto representa a transformação das prioridades da comunidade internacional, primeiro a humanidade, depois o Estado ${ }^{204}$, de tal sorte que os crimes contra a humanidade não podem ser legitimados por meio de leis nacionais ${ }^{205}$. Consagrou-se, pela voz da expansão dos direitos humanos e direito de punir pelos crimes contra a humanidade, um combate contra o princípio da soberania nas relações internacionais, que representavam escudos para a aplicação de uma justiça global.

O fundamento de punir para os crimes previstos no Estatuto inscreve-se no próprio direito internacional. Para tanto, fazemos referência à passagem conhecida da sentença do Tribunal Militar Internacional que estabelece que: "crimes contra o direito internacional são cometidos por homens, e não por entidades abstratas, e somente pela punição dos indivíduos que cometeram tais crimes as regras do direito internacional podem ser cumpridas"206. Os princípios fixados no Estatuto do Tribunal Militar Internacional tiveram aplicação tanto em Nuremberg quanto nos processos por crimes de guerra em Tóquio, pelo Tribunal Militar Internacional para o Extremo Oriente.

Com as lições aprendidas da $1^{a}$ Guerra Mundial, os aliados se preparam para garantir que os julgamentos efetivamente ocorressem, o que resultou nas 21 acusações, 12 condenações à pena de morte, 3 condenações a prisão perpétua, 4 condenações a penas de prisão entre 10-20 anos, e três absolvições, além da declaração de 4 grupos considerados organizações criminosas (dos líderes políticos a funcionários do partido nacional-socialista,

${ }^{203}$ VIADA, Natacha G. Derecho penal y globalización, op. cit., p. 63. No mesmo sentido, WERLE, Gerhard. Tratado de derecho penal internacional, p. 43.

${ }^{204}$ VIADA, Natacha G. Derecho penal y globalización, op. cit., p. 63.

${ }^{205}$ Para uma abordagem crítica da flexibilização do conceito de soberania pelo direito penal internacional, v. ROBINSON, Darryl. "The identity crisis of international criminal law", Leiden Journal of International Law, 21, 2008, pp. 956-961. De maneira irônica, afirma o autor que o conceito de soberania é um inimigo tradicional, a pedra que quer fazer o avanço dos direitos humanos tropeçar. Esse robusto pilar começa a sofrer uma erosão progressiva pelas mãos das forças liberais a serviço das sociedades democráticas, especialmente no âmbito dos direitos humanos (citando, nessa parte, a decisão no caso Tadic, decisão no pedido da defesa sobre a jurisdição, Câmara de Apelação, TPII, IT-94-I-A, de 2 de outubro de 1995, § 55.).

206 TMI, Sentença de 1.10.1946. 
a Gestapo, o Serviço de Segurança e a Segurança Estatal). A sentença foi pronunciada entre os dias 30 de setembro e $1^{\circ}$ de outubro de $1946^{207}$, e representa um relevante documento histórico e jurídico pois, avaliando as provas coligidas, ao mesmo tempo passa em revista os crimes do III Reich e fixa as regras e os princípios que inspirarão o direito penal internacional dali em diante.

\section{b) Tóquio: Tribunal Militar do Extremo Oriente}

O Tribunal Militar do Extremo Oriente - Tribunal de Tóquio, por sua vez, teve por objeto a agressiva política de guerra do Japão, instituído por decreto do comandante das forças aliadas, Douglas MacArthur, em 19 de janeiro de 1946, seguindo o ETMI. Os trabalhos do Tribunal de Tóquio resultaram na acusação de 28 antigos generais e políticos japoneses, todos condenados. Destes, 7 foram condenados à pena capital, 16 condenados a prisões perpétuas, um a prisão de 20 anos e outro a prisão de 7 anos.

Uma diferença importante entre os dois tribunais era o de que o Tribunal de Tóquio procurava julgar principalmente os responsáveis pelos crimes contra a paz, tendo concluído que houve uma conspiração para levar a cabo uma guerra de agressão e que esta se havia perpetrado por meio de diversas guerras em diversos países, tendo como base jurídica para o castigo a violação ao Pacto Briand-Kellog de $1928^{208}$. As críticas, nesse sentido, foram a de que o Tribunal tinha sido usado como instrumento de vingança dos norteamericanos contra o ataque a Pearl Harbour, além de ser uma forma de justificar a utilização de armas nucleares contra o Japão ${ }^{209}$

O legado histórico e jurídico, entretanto, não é imune a controvérsias. Em primeiro lugar, porque os crimes de guerra cometido em nome dos Aliados jamais foram julgados, especialmente os ataques às cidades de Hiroshima e Nagasaki com o uso de

\footnotetext{
207 A versão original da sentença encontra-se publicada em The Trial of German Major War Criminals, Proceedings of the International Military Tribunal Sitting at Nuremberg, disponível em http://www.loc.gov/rr/frd/Military_Law/pdf/NT_Vol-I.pdf (Acesso 12.1.2015).

${ }^{208}$ RÖLING, B.V.A., The Tokyo Trial and Beyond, Reflections of a Peacemonger, Polity Press, Cambridge, 1993, pp. 2-12;

${ }^{209}$ CASSESE, A., "From Nuremberg to Rome: International Military Tribunals to the International Criminal Court", In: CASSESE, A; GAETA, P.; JONES, J.R.W. The Rome Statute of the International Criminal Court: a Commentary, Oxford: Oxford Univ. Press, 2002, p. 8.
} 
bombas nucleares. Em segundo, porque tratou-se de um tribunal constituído posteriormente aos fatos, inclusive para punir crimes sobre os quais havia a dúvida se seriam puníveis no momento em que os fatos foram praticados, com aplicação de penas retroativas. A solução foi considerar que o direito de Nuremberg constitui-se a partir das bases do direito internacional consuetudinário, conforme abordaremos no terceiro capítulo. De toda forma, ainda que essa justiça tenha sido tachada de "justiça dos vencedores sobre os vencidos" e não tenha sido acompanhada de uma autocrítica dos Aliados em relação a alguns dos métodos empregados para alcançar a vitória sobre o Eixo ${ }^{210}$, há que ressaltar a importância dos Tribunais, conforme YÁNEZ-BARNUEVO, nos seguintes termos:

\begin{abstract}
"Primeiramente, demonstrou que era factível uma justiça penal internacional que evitasse tanto a pura e simples vingança como a simples impunidade por fatos horrendos. Em segundo lugar, ao centrar as responsabilidades nos dirigentes e nos principais executores, excluiu o fantasma da "culpabilidade coletiva" que poderia pesar sobre nações inteiras durante muito tempo. Finalmente, estabeleceu pautas segundo as quais haveria de julgarse no futuro o comportamento de responsáveis políticos ou autoridades militares de qualquer país em circunstâncias de semelhante gravidade" 211 .
\end{abstract}

\title{
c) Lei $\mathbf{n}^{\circ} 10$ do Conselho de Controle Aliado
}

Outro documento importante na construção do direito penal internacional foi a Lei $\mathrm{n}^{\mathbf{0}} 10$ sobre Castigo de Pessoas que fossem culpadas de terem cometido Crimes de Guerra, Crimes contra a Paz ou Crimes contra a Humanidade, do Conselho de Controle Aliado, de 20 de dezembro de $1945^{212}$, utilizada no pós-guerra para processamento nacional de crimes praticados sob influência da política nazista. A principal diferença em relação ao Estatuto do TMI era a omissão da conexão entre o estado de guerra para a caracterização dos

\footnotetext{
${ }^{210}$ Para uma análise crítica da forma como estabelecido e conduzido os julgamentos pelo Tribunal de Tóquio, v. YASUANI, Onuma. "The Tokyo Trial: between Law and Politics". In: CHIHIRO, Hosoya. The Tokyo War Crimes - an International Symposium., 1986, pp. 45-52.

211 YÁNEZ-BARNUEVO, Juan Antonio, "La Conferencia de Roma y el Estatuto de la Corte Penal Internacional: balance y perspectivas". In: Creación de una jurisdicción penal internacional, Colección Escuela Diplomática no 4, Madri, 2000, p. 19 (trad. libre).

${ }^{212}$ Control Council Law n $\mathrm{n}^{\circ}$ 10, "Punishment of Persons Guilty of War Crimes, Crimes against Peace and against Humanity", 20 de dezembro de 1945, Official Gazette of the Control Council for Germany, n 31, 31 de janeiro de 1946, pp. 50-55.
} 
crimes contra a humanidade, permitindo, portanto, o julgamento dos crimes cometidos antes de 1939 contra os civis alemães, incluindo a perseguição dos judeus e a eutanásia dos inválidos. Aplicada tanto pelos tribunais alemães, quanto norte-americanos ${ }^{213}$, mas também britânicos, visava a punição de crimes ocorridos com reflexos locais. Os julgamentos do pósguerra espalharam-se por todo Leste Europeu, especialmente pela antiga Tchecoslováquia, Romênia e ex-União Soviética, sendo o mais famoso aqueles ocorridos na Polônia, em 1947, na Cracóvia, no qual foram julgados diversos funcionários do campo de concentração de Auschwitz, como o comandante Rudolf Höss, e o de Jerusalém, de Adolf Eichmann, principal arquiteto da deportação dos judeus europeus, em 1961. WERLE refere-se a essa lei como um produto do direito de ocupação, baseado em JESCHECK ${ }^{214}$, cujas disposições sobre direito internacional material são reconhecidas como expressão do direito consuetudinário.

Os princípios do julgamento de Nuremberg (Estatuto e decisões) foram confirmados pela Resolução 95(I) de 11 de dezembro de 1946 da Assembleia Geral das Nações Unidas. A Comissão de Direito Internacional - CDI, criada em 1947 ${ }^{215}$, com a missão de codificar e desenvolver progressivamente o direito internacional, foi encarregada da preparação de uma codificação dos crimes de direito internacional e dos princípios contidos no Estatuto e sentenças do TMI. Em 1954 a CDI apresentou o primeiro projeto para um "Código de Crimes contra a Paz e a Segurança da Humanidade", alterados posteriormente em 1991 e 1996. Estabelece-se, assim, que os "crimes contra a paz e a segurança da humanidade, definidos no Código, são crimes contra o direito internacional, pelos quais os indivíduos responsáveis devem ser punidos”.

${ }^{213}$ V. BUSCHER, Frank M., The US War Crimes Trial Program in Germany, 1946-1955, Westport, CT: Greenwood Press, 1989.

${ }^{214}$ JESCHECK, Hans Heinrich. Die Verantworlichkeit der Staatsorgane nach Völkerstrafrecht, L. Röhrscheid, 1952, p. 178, conforme citado por WERLE, Gerhard. Tratado de Derecho Penal Internacional, op. cit., p. 11.5 ${ }^{215}$ Por meio da Resolução $\mathrm{n}^{\circ} 174$ (II), de 21 de novembro de 1947, cujo estatuto está publicado em: http://legal.un.org/ilc/texts/instruments/english/statute/statute_e.pdf (Acesso 12.07.2014). 


\subsubsection{Tribunais Ad Hoc}

\section{a) Iugoslávia: Tribunal Penal Internacional para a ex-Iugoslávia}

O conflito que ocorreu entre as diversas repúblicas que compunham a antiga Iugoslávia levou o Conselho de Segurança da ONU a tratar a crise sob o Capítulo VII da Carta das Nações Unidas - CNU, diante das diversas violações ao direito internacional humanitário reportadas. Trata o Capítulo VII das ações em caso de ameaça à paz, e autoriza o uso de intervenção militar, "por meio de forças aéreas, navais ou terrestres, a ação que seja necessária para manter ou restabelecer a paz e a segurança internacionais" (art. 42 da CNU). Nesse cenário, o Conselho de Segurança estabeleceu em 25 de maio de 1993, numa votação unânime, o Tribunal Internacional para o julgamento dos supostos responsáveis pelas graves violações de direito internacional humanitário cometidas no território da ex-Iugoslávia, cuja sede se estabeleceu em Haia (Resolução n ${ }^{\circ}$ 827, que previu o Estatuto do Tribunal Penal Internacional para a ex-Iugoslávia - TPII).

A comissão de especialistas formada para investigar e informar sobre as evidências das graves violações das Convenções de Genebra de 1949 e outras do direito internacional humanitário, confirmou a prática de assassinatos massivos, detenções sistemáticas e organizadas, estupro de mulheres e prática de limpeza étnica ${ }^{216}$. Como primeira experiência institucional de direito internacional penal após Nuremberg e Tóquio, o Conselho de Segurança determinou a instituição do TPII pela conjunção de três fatores principais: o fracasso do Estado como mantenedor de uma ordem pública, ao não conseguir evitar uma massiva violação dos direitos humanos; o apoio do Conselho de Segurança,

216 Segundo o relatório do Secretário Geral para o presidente do Conselho de Segurança (Doc. NU: S/1994/674): "On the basis of the information gathered, examined and analyzed, the Commission has concluded that grave breaches of the Geneva Conventions and other violations of international humanitarian law have been committed in the territory of the former Yugoslavia on a large scale, and were particularly brutal and ferocious in their execution. The practice of so-called 'ethnic cleansing' and rape and sexual assault, in particular, have been carried out by some of the parties so systematically that they strongly appear to be the product of a policy, which may also be inferred from the consistent failure to prevent the commission of such crimes and to prosecute and punish their perpetrators", apresentado por Boutros-Gali (disponível em http://www.icty.org/x/file /About/OTP/un_commission_of_experts_report1994_en.pdf, Acesso 12.09.2013) 
unindo a atuação propositiva de intervenção militar à falta de membros que vetassem iniciativas nesse sentido; e, por fim, a intensa e detalhada cobertura dos meios de comunicação das atrocidades, levando a opinião pública a demandar reações da comunidade internacional $^{217}$.

Quando o processo de elaboração de um código e um tribunal penal internacional de caráter permanente parecia uma realidade ainda distante, as atrocidades cometidas na antiga Iugoslávia e posteriormente em Ruanda anteciparam o processo, também favorecido pelo cenário político mundial pós-Guerra Fria, fazendo desvanecer a animosidade que predominou por meio século no contexto bipolar geopolítico. Em um ambiente não mais bipolar, mas multipolar, aumentou a fragmentação da comunidade internacional ao mesmo tempo em que se intensificou a sensação de desordem, motivando, inclusive, o aumento do nacionalismo e fundamentalismos, numa espiral de conflitos armados internos. A implosão de sociedades multiétnicas pré-existentes levou a violações graves ao direito humanitário internacional em escala comparável, em alguns aspectos, àquelas cometidas durante a II Guerra Mundial $^{218}$. Outro significativo fator que contribuiu para a construção do direito penal internacional foi a importância cada vez maior da doutrina de direitos humanos, que rapidamente se tornaria uma espécie de "religião secular" 219 , sobretudo pela confirmada deficiência de seus mecanismos de monitoramento de respeito aos direitos humanos, ganhando voz a ideia de que deveriam ser punidos aqueles indivíduos responsáveis pelas violações, na perspectiva de que a efetivação das punições contribuísse para alastrar a ideia de cumprimento dos standards de proteção dos direitos humanos.

Diante da comoção da opinião pública que exigia medidas urgentes, de eficácia imediata, prescindiu-se do procedimento que seria o mais adequado para o estabelecimento de um tribunal internacional: a conclusão de um tratado internacional por meio do qual os Estados Partes criariam um tribunal, aprovariam seu estatuto, sendo ainda preferível que tal tratado fosse escrito por um órgão internacional apropriado, como a Assembleia Geral, e aberto à assinatura e ratificação dos Estados. Diante dos fatos relatados, pois que o modelo ideal levaria muitos anos e envolveria debates intensos, optou-se pela criação dos tribunais

${ }^{217}$ Avaliação realizada por BOS, Adriaan, “The experience of the preparatory commitee”. In: POLITI, Mauro; NESI, Giuseppe (eds.), The Rome Statute of the ICC: a challenge to impunity, Ashgate/Dartmouth, Asdershot, 2001 , pp. 22.

${ }^{218}$ CASSESE, A. International Criminal Law, Oxford, p. 325.

${ }^{219}$ CASSESE, A. Idem, ibidem. 
por meio de resoluções do Conselho de Segurança ${ }^{220}$. Outra questão também levantada foi a do caráter recomendatório das resoluções da Assembleia Geral, sem o caráter obrigatório das decisões próprias de Tribunal.

A competência do TPII ${ }^{221}$ era a de apurar e julgar as violações às Convenções de Genebra (art. $2^{\circ}$ ), crimes de guerra (art. $3^{\circ}$ ), genocídio (art. $4^{\circ}$ ), crimes contra a humanidade (art. $5^{\circ}$ ). Com base no relatório do Secretário Geral, o princípio do nullum crimen sine previa lege deveria ser aplicado em relação aos "crimes contra o direito humanitário que é sem nenhuma dúvida o direito consuetudinário de tal forma que o problema da adesão de alguns mas não de todos os Estados a algumas convenções específicas não surja. Isso parece ser particularmente importante no contexto de um tribunal internacional processando pessoas responsáveis pelas graves violações em direito humanitário internacional"222.

A questão da legitimidade de se criar um Tribunal com base numa decisão do Conselho de Segurança, sem o respaldo da Assembleia Geral das Nações Unidas, foi intensamente debatida, encontrando artificiosamente justificativa para sua instauração com base no arts. 2.5, 25, 48 e 49 da $\mathrm{CNU}^{223}$. Para CASSESE, o Tribunal representou uma tentativa de disfarçar a impotência diante da crise humanitária que grassava na região, tendo fracassado todas as instituições que poderiam ter atuado para evitar os massacres. Ao mesmo tempo, necessitavam respostas as indagações sobre a legitimidade de instauração de um tribunal internacional pelo Conselho de Segurança. O Secretário Geral defende que era necessária a instauração do tribunal internacional diante da ameaça à paz que representava a situação na ex-Iugoslávia e que a instalação de um tribunal penal contribuiria para a restauração da paz $^{224}$. Mas esse assunto foi especialmente tratado no julgamento do caso

\footnotetext{
${ }^{220}$ Resolução do Conselho de Segurança da ONU R/RES/827, de 25 de maio de 1993 e Resolução do Conselho de Segurança da ONU R/RES/955, de 8 de novembro de 1994. Também, para maiores aprofundamentos, GIL GIL, Alicia. Derecho Penal Internacional, op. cit., pp. 61-62.

${ }^{221}$ Neste momento, abordaremos somente os aspectos relativos à instalação e competência do TPII, visto que o conteúdo de seus julgados, compondo a parte material do direito penal internacional, será abordado ao longo de todo o capítulo e do próximo. O mesmo em relação ao TPIR.

${ }^{222}$ Doc. ONU, S/25704, de 3 de maio de 1993, § 34.

${ }^{223}$ ZAFRA ESPINOSA DE LOS MONTEROS, Rafael. "El establecimiento convencional de la CPI: grandes y servindumbres", p. 169. In: CARRILLO SALCEDO, J.A. (Coord.). La criminalización de la barbárie: la CPI, Madri: CGPJ, 2000. CASSESE, Antonio. "From Nuremberg to Rome: International Military Tribunals to ICC". In: CASSESE, A. et. al. The Rome Statute of the ICC: a Commentary, Oxford: Oxford Univ. Press, 2002 , p. 13.

${ }^{224}$ Doc ONU S/1993/25074.
} 
Tadic, quando o TPII confirmou esse entendimento na decisão do agravo de instrumento (interlocutory appeal) de 2 de outubro de $1995^{225}$, no qual a defesa questionava especificamente a jurisdição do tribunal.

Nessa ocasião, a defesa apresentou os seguintes argumentos:

a) Fundação ilegal do tribunal internacional;

b) Primazia indevida do tribunal internacional sobre as cortes nacionais;

c) Falta de jurisdição ratione materiae.

Todos estes argumentos foram rejeitados pelo tribunal, após detalhado exame sobre a jurisdição e sua atribuição de definir a "competência da competência". Considerouse, inclusive, que o art. 14.1 do Pacto Internacional sobre os Direitos Civis e Políticos, ao afirmar que:

\begin{abstract}
"Todas as pessoas são iguais perante os tribunais e as cortes de justiça. Toda pessoa terá o direito de ser ouvida publicamente e com devidas garantias por um tribunal competente, independente e imparcial, estabelecido por lei, na apuração de qualquer acusação de caráter penal formulada contra ela ou na determinação de seus direitos e obrigações de caráter civil (...)”
\end{abstract}

não afirma que o tribunal deva ser pré-estabelecido por lei. Essa interpretação é feita pelo Comitê de Direitos Humanos das Nações Unidas, referindo-se a que a vontade do Pacto é a de que se deve assegurar que qualquer tribunal, seja ele extraordinário ou não, deve "genuinamente conferir ao acusado as amplas garantias de um julgamento justo, previsto no art. 14 do PIDH"226. Com base no Estatuto do TPII, das regras de procedimento e de prova, considerou-se que havia respeito ao Estado de Direito e, portanto, que o tribunal respeitava os critérios para ser considerado como "estabelecido por lei".

\footnotetext{
${ }^{225}$ Caso Tadic, TPII (IT-94-1-A), decisão sobre o pedido da defesa questionando a jurisdição do TPII, de 5 de outubro de $1995, \S 2$.

226 Nos termos do Comentário Geral ao Article 14, H.R. Comm. $43^{\text {a }}$ Sessão, Sup. no 40, § 4 ${ }^{\circ}$, Doc. ONU A/43/40 (1988), Cariboni contra Uruguay H.R.Comm. 159/83. 39 a Sessão Sup. No. 40 Doc. ONU A/39/40. De maneira semelhante, pela Comissão Interamericana de DH, Annual Report 1972, OEA/Ser. P, AG/doc. 305/73 rev. 1, 14 de março de 1973, item1; Inter-Am C.H.R., Annual Report 1973, OEA/Ser. P, AG/doc. 409/174, 5 de março de 1974, itens 2-4.).
} 
Com relação à submissão a uma corte internacional quando ele poderia ser julgado nacionalmente, a corte afirma que: "de fato, ele será removido de seu foro nacional "natural", mas ele será levado diante de um tribunal no mínimo igualmente justo, mais distante dos fatos do caso e que adotará uma visão mais ampla do assunto" 227 . Não se trata, portanto, de um argumento jurídico, que deveria ser muito mais substancioso à hora de subrogar-se uma garantia processual penal ao juiz natural da causa. Nota-se que esse tipo de critério de definição de competência será melhor endereçado na redação do princípio da complementariedade da jurisdição do tribunal permanente penal internacional.

À diferença dos tribunais de Tóquio e Nuremberg, o TPII não era um tribunal militar, e os juízes que compunham as câmaras não eram nacionais das potências vencedoras julgando os vencidos, mas eleitos entre juristas de reconhecido prestígio de diferentes nacionalidades. Entretanto, não tendo sido criado por resolução da Assebleia Geral, mas do Conselho de Segurança, deixou de obter a legitimidade máxima das instâncias nas Nações Unidas.

\section{b) Ruanda: Tribunal Penal Internacional para Ruanda}

Outro episódio de extensivas consequências humanitárias ocorreu em Ruanda, em abril de 1994, em seguida à queda do avião em que viajavam os presidentes de Ruanda e Burundi ocasionada pelo disparo de um míssil. Um novo governo instalou-se em julho de 1994, após uma das guerras civis mais cruéis da história. Segundo MINIUCI ${ }^{228}$, esse ataque foi o estopim para a retomada do conflito, que já vinha sendo gestado há décadas. Nos três meses seguintes ao ataque, cerca de 800 mil tutsis foram mortos. Além de assassinatos de indivíduos, cometeram-se também execuções em massa, estupros, pilhagens, torturas, entre diversas outras condutas submetidas a exame da comunidade internacional.

Diante do desastre humanitário que se conheceu, voltando a atuar com base no Capítulo VII da CNU, o Conselho de Segurança adota a Resolução nº 955 determinando a criação do Tribunal Internacional para o julgamento dos crimes internacionais perpetrados

${ }^{227}$ Conforme Caso Tadic, supra, § 62 (trad. livre).

228 MINIUCI, Geraldo. "O genocídio e o crime de genocídio". RIBCCRIM n . 84, mar-abr/2010, item 4. 
em Ruanda (TPIR). Por ocasião dos conflitos, Ruanda era um dos membros provisórios do Conselho de Segurança e pediu que fosse determinada a criação de um tribunal. Era uma forma de o novo governo pavimentar o caminho da reconstrução pós-conflito, de atrair a aprovação internacional ao novo regime por meio de um processo de autoavaliação e processamento judicial internacional pelos mais graves abusos que ocorreram durante a guerra civil ${ }^{229}$. Entretanto, o próprio país votou contra a Resolução ${ }^{\circ} 955$ do Conselho de Segurança por discordar de algumas de suas disposições ${ }^{230}$. Entre os motivos indicados pelo governo, destacam-se os seguintes: a) o país não aceitava a limitação ratione temporis de competência para os atos cometidos em 1994, visto que desde antes já vinham sendo planejados e executados atos graves, inclusive massacres em menor escala, mas em condições de subsumi-los ao crime de incitamento ao genocídio, previsto no art. 2 do Estatuto do TPIR; b) a estrutura do tribunal não parecia adequada, ficando a impressão, nas palavras do Embaixador de Ruanda para a ONU, M. Bakuramutsa, que se estaria apenas apaziguando a consciência da comunidade internacional ${ }^{231}$; c) o país estava preocupado com a participação de países que haviam apoiado o genocídio na indicação de juízes para o tribunal; d) também não aceitavam a prisão de pessoas sentenciadas pelo tribunal em países terceiros, e que esses países terceiros tivessem poder sobre os presos; e) tampouco concordava com a exclusão da pena de morte entre as penas aplicáveis pelo tribunal, por se tratar de uma pena ainda em vigor no Código Penal do país ${ }^{232}$ e desde já adiantou a controvérsia: os acusados julgados pelo TPIR poderão receber uma pena menor do que os acusados de crimes muito menos graves quando julgados pela justiça local (Arushax Kigali), como de fato ocorreu; e, ainda d) insistiu-se para que a sede do tribunal ficasse em Ruanda, com efeitos diretos na percepção da população dos julgamentos e efeitos da justiça criminal internacional para os crimes graves ocorridos no país. Apesar do voto negativo, o país afirmou que cooperaria com o funcionamento do tribunal em qualquer caso.

O TPIR seguiu a mesma estrutura do TPII, prevendo os crimes de sua competência em seu Estatuto, a mesma forma de atuação da procuradoria e da Corte de Apelação. E, como tem sido visto em direito internacional, a cada instituição, busca-se aprimorar alguns dos seus aspectos institucionais e de funcionamento, especialmente diante

${ }^{229}$ Cassese, A. International Criminal Law, p. 327.

${ }^{230}$ Doc. ONU S/1994/1115 e S/PV.3453, respectivamente.

${ }^{231}$ Cf. Doc. ONU S/PV.3453, p. 15

${ }^{232}$ Conforme os arts. 26 e 312 (homicídio premeditado) do Código Penal Ruandês (Decreto-Lei no $21 / 77$ de 18 de Agosto de 1977, Journal Officiel de la République Rwandaise de $1^{\circ}$ de julho de 1978). 
da experiência retratada pelo tribunal que o antecedeu. Isso porque, diante de um conflito interno, alterou-se sua competência material e temporal, para abranger apenas os fatos ocorridos após 1994, mas especialmente em relação aos crimes contra a humanidade. Também não se faz mais referência à existência de um conflito armado para a definição da competência do tribunal, como vinha sendo previsto nos estatutos de tribunais anteriores. A configuração de crimes contra a humanidade, portanto, poderia ocorrer dentro de uma mesma base nacional, étnica, racial ou religiosa, inclusive em tempos de paz, em referência à decisão no caso Tadic ${ }^{233}$.

Entre os principais julgados, citamos o Caso Akayesu, major da região de Taba, onde milhares de tutsis foram vítimas de estupro, tortura e assassinato. Inicialmente recebeu 12 acusações de genocídio, crimes contra a humanidade e violações às Convenções de Genebra na forma de assassinato, tortura e tratamento cruel, e posteriormente foram incluídas ainda outras 3 acusações de crimes contra a humanidade e violações do Artigo $3^{\circ}$, comum, do Protocolo Adicional II por estupro, atos desumanos e violação moral. Pela primeira vez se considerava o estupro como elemento de genocídio em direito internacional. Em 2 de setembro de 1998, o TPIR condenou Akayesu por 9 acusações de genocídio, incitação direta e pública para o cometimento do genocídio e crimes contra a humanidade pela exterminação, assassinato, tortura, estupro e outros atos desumanos ${ }^{234}$.

Outros dois precedentes também merecem ser citados como importantes resultados e efeitos jurídicos das decisões do TPIR. Foi levado a julgamento Jean Kambanda, que foi o Primeiro Ministro durante o governo interino de Ruanda, durante os 100 dias de genocídio, reconhecendo-se culpado diante de 6 acusações de genocídio, conspiração para o cometimento de genocídio, incitamento direto e indireto para o cometimento de genocídio, cumplicidade em genocídio e crimes contra a humanidade. Foi a primeira vez que um chefe de Estado fora condenado por genocídio, mas também que uma pessoa se declarara culpada pelo cometimento do genocídio ante um tribunal penal internacional.

\footnotetext{
${ }^{233}$ Sentença da Corte de Apelação de 2 de outubro de 1995 (N. IT-94-1-AR72).

${ }^{234}$ Conforme o comunicado do Tribunal, essa condenação representou "the first in which an international tribunal was called upon to interpret the definition of genocide as defined in the Convention for the Prevention and Punishment of the Crime of Genocide” (v. ICTR Fact Sheet No. 1, The Tribunal at a Glance).
} 
Também o TPIR julgou acusações levantadas contra diretores de veículos de mídia, em que se discutiu pela primeira vez desde Nuremberg o papel da mídia na disseminação do discurso do ódio e sua relação com a incitação ao genocídio ${ }^{235}$. Esse tema esteve presente no julgamento de Ferdinand Nahimana e Jean-Bosco Barayagwiza, líderes da Radio Television Libre Milles Collines (RTLM), e de Hassan Ngeze, fundador e diretor do jornal Kangura (reunidos sob a denominação comum "The Media Case" - Prosecutor v. Ferdinand Nahimana, Jean-Bosco Barayagwiza e Hassan Ngeze). Em 2003, Nahimana, Barayagwiza e Ngeze foram condenados pelos crimes de genocídio, conspiração para cometer genocídio, incitação direta e indireta para o cometimento de genocídio e crimes contra a humanidade ${ }^{236}$

Após a instalação dos dois Tribunais ad hoc, movimentando grandes esforços do Conselho de Segurança além de recursos financeiros, logísticos, e tempo, justificadamente pode-se dizer que ele chegou a um ponto de "tribunal fatigue", na feliz expressão cunhada por David SCHEFFER ${ }^{237}$. Apesar do grande passo dado em relação à construção de um sistema judiciariforme internacional, o Conselho de Segurança estava constantemente envolvido na defesa dessas instituições contra as críticas, ao mesmo tempo que tendo que responder aos grandes desafios logísticos, consumo de recursos para suas ações, de modo que o Conselho de Segurança viu-se inclinado a não mais pretender a criação destes órgãos.

\footnotetext{
${ }^{235}$ Relevantes reflexões trazidas sobre a criminalização do discurso do ódio, mas também a interpretação extensiva do TPIR, v. ORENTLICHER, Diane F. "Criminalizing Hate Speach in the Crucible of Trial: Prossecutor vs. Nahimana". American University International Law Review, no 21, v. 4, pp. 557-593.

${ }^{236}$ TPIR, Caso Jean-Paul Akayesu (ICTR-96-4-T), julgamento pela Câmara de Julgamento, decisão de 2 de setembro de 1998; TPIR, Caso Jean Kambanda (ICTR 97-23-S), julgamento pela Câmara de Julgamento, decisão de 4 de setembro de 1998; TPIR, Caso Ferdinand Nahimana, Jean-Bosco Barayagwiza e Hassan Ngeze (ICTR-99-52-T), julgamento pela Câmara de Julgamento, decisão de 3 de dezembro de 2003; TPIR, Caso Ferdinand Nahimana, Jean-Bosco Barayagwiza e Hassan Ngeze (ICTR-99-52-A), julgamento pela Câmara de Apelação, decisão de 28 de novembro de 2007.

${ }^{237}$ Assessor ao Representante Permanente dos Estados Unidos na ONU, citado por BASSIOUNI, M.Cherif. The Statute of ICC: A documentary history, nota 10, Ardsley-NY: Transnational Publishers, 1998.
} 


\subsubsection{Tribunais Mistos Ad Hoc $\mathrm{H}^{238}$}

Enfrentando diversas críticas relacionadas à instalação dos tribunais internacionais ad hoc, notadamente com relação aos seguintes aspectos: altos custos; excessivamente lentas em seus processamentos; sua distância em relação ao local dos fatos e, consequentemente seu limitado impacto em relação ao resultado dos julgamentos na população local; e ausência de foco em relação às pessoas sujeitas à jurisdição da corte, resultando no processamento de graduados subalternos na hierarquia dos crimes perpetrados, optou-se pelo estabelecimento de tribunais locais, com a presença de juízes estrangeiros julgando em câmaras também compostas por juízes nacionais (composição híbrida), em julgamentos que se pretendiam mais rápidos e com orçamento reduzido. Consoante será visto, a instalação pode ocorrer de diversas formas, ou por ato internacional das Nações Unidas, com estatuto e instituição dessa natureza, ou por ato local, com apoio e recursos complementados pelas Nações Unidas.

Assim, para além dos tribunais internacionais, localizados fora dos territórios de conflito e compostos por juízes de outros países, o Conselho Geral também considerou a possibilidade de instalação de tribunais ad hoc em Serra Leoa, Timor Leste, Kosovo, Líbano e Camboja em finais da década de 1990 e começo de 2000. Foram tribunais com composição mista, juízes nacionais e internacionais, para julgarem as graves violações ocorridas nos confrontos que resultaram na troca de seus governos.

\section{a) Serra Leoa: Tribunal Especial para Serra Leoa}

O Tribunal Especial para Serra Leoa foi estabelecido em 2002 por meio de um requerimento do governo de Serra Leoa às Nações Unidas ${ }^{239}$ em 2000 para julgar os graves crimes contra civis e os capacetes azuis da ONU durante a guerra civil. Com uma estrutura

\footnotetext{
${ }^{238}$ Mencionaremos de forma superficial os demais tribunais de caráter internacional havidos de forma a fornecer um panorama completo a experiência nessa área. Não aprofundaremos nossa análise no funcionamento e resultados pela limitação que temos que impor a essa questão. Essa limitação, entretanto, não prejudica os objetivos centrais do trabalho.

${ }^{239}$ Doc. ONU S/2000/786, Carta de 9 de Agosto de 2000 do Representante de Serra Leoa às Nações Unidas.
} 
híbrida, foi o primeiro tribunal internacional ${ }^{240}$ localizado no próprio país que sediou os crimes julgados depois de Nuremberg e também a procurar ter efeitos duradouros e extensivos no local, com uma transição a um mecanismo residual de acompanhamento.

A competência da corte foi definida compreendendo o processamento de indivíduos que "portam maior responsabilidade por violações graves ao direito internacional humanitário e do direito de Serra Leoa, cometidas no território de Serra Leoa", especificamente os crimes contra a humanidade, violações às Convenções de Genebra, ao direito internacional humanitário, e crimes tipificados pelo direito local ocorridos a partir de 30 de novembro de 1996.

\section{b) Timor Leste: Sessão Especial dos Crimes Graves para o Timor Leste}

A Resolução n ${ }^{\circ} 1272$ da UNTAET - United Nations Transitional Administration for East Timor 2000/11, de 6 de junho de 2000, que administrava transitoriamente o Timor Leste até a eleição e posse do novo governo ${ }^{241}$, conferiu competência à Sessão Especial dos Crimes Graves para julgamento dos casos de genocídio, crimes de guerra, crimes contra a humanidade, assim como assassinato e crimes sexuais ocorridos no período de $1^{\circ}$ de janeiro de 1999 a 25 de outubro de 1999.

Os julgamentos ocorriam no tribunal distrital de Dili, em composição híbrida com a presença de juízes estrangeiros e nacionais. Foram indiciadas quase 400 pessoas, dos quais diversos indonésios, inclusive os de mais alto comando militar à época, que o governo indonésio se recusava a entregá-los à $\mathrm{ONU}^{242}$.

\footnotetext{
240 Doc. ONU S/Res/1315, de 14 de agosto de 2000.

241 Ocorrida apenas em 2002.

242 A Indonésia criou um tribunal nacional para apurar os mesmos crimes, mas com resultados frágeis. Conforme o relatório apresentado à Assembleia Geral (Doc. ONU S/2005/458), § 335: "As discussed above, the Commission has concluded that the 'Ad Hoc' Prosecutors leading these trials were neither adequately prepared nor knowledgeable enough to prosecute complex crimes against humanity cases. The Commission does not have sufficient evidence to address the motivations of the Prosecutors of the Attorney-General Office, but is compelled to conclude that the Indonesia ad hoc judicial process for East Timor has failed largely due to the incapacity of the prosecution to seriously and adequately prove its case against the defendants. This failure, viewed in conjunction with the lack of political will, plays a significant role in the Commission".
} 


\section{c) Camboja - Câmaras Extraordinárias no Tribunal do Camboja}

No caso da transição do Camboja, o Parlamento adotou, após negociações com as Nações Unidas, em 2001, uma lei criando a Câmara Extraordinária nos Tribunais do Camboja para julgar os crimes cometidos durante o período do Campuchea Democrático (1975-9), com composição híbrida. O tribunal foi criado para "julgar os líderes do Campuchea Democrático e aqueles com maior responsabilidade pelos crimes e graves violações do direito penal cambojano, das leis e costumes do direito internacional comunitário, das convenções internacionais reconhecidas pelo Camboja, cometidos entre 17 de abril de 1975 a 6 de janeiro de $1979^{243}$.

\section{d) Kosovo: Tribunal da Guerra do Kosovo e Crimes Étnicos}

Em Kosovo, ex-república iugoslava, a administração transitória das Nações Unidas (UNMIK) aprovou o Regulamento 2000/64, de 15 de dezembro de 2000, criando as sessões mistas para julgamento dos crimes de sua competência, funcionando nas cortes cossovares. Também indicou promotores públicos e juízes de instrução estrangeiros para atuar nas cortes distritais, nos casos envolvendo crimes relacionados a crimes de guerra ou inter-étnicos, ou crimes contra a propriedade relacionado a esses crimes.

\section{e) Líbano: Tribunal Especial para o Líbano ou "Tribunal Hariri”}

No caso do Líbano, as Nações Unidas firmaram um acordo com o país para a criação de um Tribunal especial, com sede na cidade de Leidschendam, na Holanda, e escritório em Beirute, com base no relatório do Secretário Geral para o Conselho de

\footnotetext{
${ }^{243} \mathrm{O}$ tribunal tem por base o acordo firmado entre a ONU e o Reino Democrático do Camboja, para o estabelecimento da Lei sobre a Criação das Câmaras Especiais, conforme http://www.eccc. gov.kh/sites/default/files/legal-documents/Agreement_between_UN_and_RGC.pdf (Acesso 30.9. 2014). A lei que governa o tribunal pode ser encontrada no link que segue: http://www.eccc.gov.kh/sites/default/files/legaldocuments/KR_Law_as_amended_27_Oct_2004_Eng.pdf (Acesso 30.9.2014). Para maiores reflexões sobre os efeitos do funcionamento do Tribunal, The Serious Crimes Process in Timor-Leste: in Retrospect, Intenational Center for Transitional Justice, março, 2006 (disponível em: http://www.ictj.org/sites /files/ICTJTimorLeste-Criminal-Process-2006-English.pdf, Acesso 30.01.2015).
} 
Segurança da $\mathrm{ONU}^{244}$, contendo o estatuto de funcionamento da corte. Inicialmente a ONU fora chamada a auxiliar o governo libanês a investigar o atentado a bomba que matou o Primeiro Ministro libanês Hafiq Hariri e outros em Beirute, em 14 de fevereiro de 2005, identificando os responsáveis e possíveis ligações com organizações criminosas. A competência do tribunal foi estendida para os atos, atendidas certas condições, ocorridos entre $1^{\circ}$ de outubro de 2004 a 12 de dezembro de 2005, aplicando-se em seu processamento o direito libanês. Assim, a extensão da competência foi definida nos seguintes termos:

"Se o tribunal entender que outros ataques que ocorreram no Líbano entre $1^{\circ}$ de outubro de 2004 e 12 de dezembro de 2005 (...) são conexos, de acordo com os princípios do direito penal e são de natureza e gravidade similar ao atentado de 14 de fevereiro de 2005, ele deverá também ter jurisdição sobre as pessoas responsáveis por estes atentados. A conexão inclui, mas não está limitada, a uma combinação dos seguintes elementos: motivo criminoso, o propósito por trás do atentado, a natureza das vítimas atingidas, o modo de ataque (modus operandi) e os perpetradores" ${ }^{245}$.

${ }^{244}$ Doc. ONU S/2006/893, de 15 denovembro de 2006.

${ }^{245}$ Idem, art. 1.1 do Anexo 1, p. 15, (trad. livre). 


\subsection{Tribunal Penal Internacional}

\subsubsection{Breve Histórico}

Com o fim da Guerra Fria, as Nações Unidas já vinham considerando o estabelecimento de um tribunal penal internacional, tendo a Assembleia Geral requerido à Comissão de Direito Internacional a tarefa de realizar um estudo a respeito ${ }^{246}$. A Comissão terminou seu trabalho em $1994^{247}$, apresentando um detalhado e abrangente relatório. A Assembleia Geral criou em 1996 um Comitê Preparatório para o Estabelecimento de um Tribunal Penal Internacional (PrepCom), apresentando na "Conferência Diplomática de Plenipotenciários das Nações Unidas sobre a criação de um Tribunal Penal Internacional" de Roma, de 15 de junho a 17 de julho de $1998^{248}$, uma Proposta de Estatuto com sugestões e opções de redações aos seus 116 artigos.

Depois de intensas negociações, finalmente o projeto com as emendas foi submetido à Comissão Plenária, que concentrava a principal missão de articular a redação e a coordenação dos grupos de trabalho. A Comissão de Redação era presidida por M. Cheriff BASSIOUNI, com destacado papel na coordenação e consistência dos encaminhamentos feitos ao projeto para a Comissão Plenária. Os Estados Unidos ${ }^{249}$ tentaram emendar o projeto para que o Tribunal não pudesse julgar membros de suas forças armadas em operações militares em outros Estados, mas o assunto não entrou em discussão a pedido da Noruega. Os Estados Unidos pediram, então, que se votasse o projeto. O resultado foi a aprovação do Estatuto de Roma e do TPI, com 120 votos a favor, 21 abstenções e 7 votos contrários. Ainda que fosse secreta, Estados Unidos, Israel e China afirmaram que votaram contra.

\footnotetext{
${ }^{246}$ Resolução da AG das Nações Unidas, 44/39 de 4 de dezembro de 1989.

${ }^{247}$ Report of the International Law Commission, 46 a sessão, 2 de maio a 22 de julho de 1994.

${ }^{248} \mathrm{O}$ interesse que despertou a conferência se reflete na quantidade de participantes que acompanharam as sessões: 160 países e como observadores 20 organizações internacionais, 14 agências especializadas das Nações Unidas e uma coalizão formada por cerca de 200 organizações não-governamentais, além de 474 jornalistas credenciados. O papel das ONGs debatendo e criticando os documentos e fazendo pressão para um maior número de adesões foi apresentado em diversos artigos, como PACE, William; THEIROFF, Mark, "Participation of NGOs". In: LEE, Roy. The International Criminal Court, the Making of the Rome Statute, Issues, Negotiations and Results. Haia: Kluwer Law International, 1999, pp. 391-398.

${ }^{249}$ SEWALL, Sarah B.; KAYSEN, Carl (eds.), The United States and the ICC: National Security and International Law, Nova Iorque: Rowan Lishers, 2000.
} 
A Ata Final da Conferência ${ }^{250}$ ordenou a constituição de uma Comissão Preparatória encarregada de elaborar os diversos documentos que complementariam o funcionamento do Tribunal, quais sejam: as regras para o procedimento e prova, os elementos dos crimes, um acordo entre a relação entre o Tribunal e a ONU, os princípios básicos do acordo relativos à sede do Tribunal, o regulamento financeiro, um acordo sobre privilégios e imunidades do Tribunal, um orçamento para o primeiro exercício financeiro e as regras para o funcionamento da Assembleia dos Estados Partes ${ }^{251}$.

Encerrava-se, com isso, um longo caminho iniciado no final do século $\mathrm{XIX}^{252} \mathrm{e}$ que inscreveu na história um arcabouço institucional único dentro do direito internacional dos direitos humanos, um dos mais importantes paradigmas para a proteção internacional dos direitos humanos desde a Declaração Universal dos Direitos Humanos de 1948. Após mais de 50 anos da declaração das normas protetivas que modificou o repertório das relações internacionais desde então, o Tribunal Penal Internacional é saudado como um mecanismo de aplicação efetiva do direito nos casos das piores violações dos direitos humanos ${ }^{253}$.

Atualmente o TPI está investigando a situação de crimes contra o direito internacional de sua competência nos seguintes países:

a) Uganda: Casos contra Joseph Kony, Vincent Otti, Okot Odhiambo e Dominic Ongwen ${ }^{254}$;

\footnotetext{
${ }^{250}$ Doc. ONU A/CONF.183/10 de 17 de julho de 1998.

251 Idem, Resolução F.

252 Referência feita ao Projeto Moynier, de 1872.

${ }^{253}$ Cf. URIOS MOLINER, Santiago. "Antecedentes históricos de la CPI", in La Corte Penal Internacional un estudio interdisciplinar. Valência: Tirant lo Blanch, 2003, pp. 23-59. Para além dos objetivos enunciados no Tratado, JAPIASSÚ identifica o projeto do TPI com o projeto para a paz perpétua de Kant, animado pela expectativa de um direito cosmopolita que procurasse assegurar uma hospitalidade universal. JAPIASSÚ, Carlos Eduardo Adriano. O Tribunal Penal Internacional - a internacionalização do direito penal. Rio de Janeiro: Lumen Juris, 2004, pp. 117 ss.

${ }^{254}$ Caso ICC-02/04-01/05
} 
b) República Democrática do Congo: Casos contra Thomas Lubanga Dyilo ${ }^{255}$; Bosco Ntaganda ${ }^{256}$; Germain Katanga ${ }^{257}$; Mathieu Ngudjolo Chui ${ }^{258}$; Callixte Mbarushimana $^{259}$ e Sylvestre Mudacumura ${ }^{260}$;

c) Darfur, Sudão: Casos contra Ahmad Muhammad Harun ("Ahmad Harun") e Ali Muhammad Ali Abd-Al-Rahman ("Ali Kushayb")261; Omar Hassan Ahmad Al Bashir $^{262}$; Bahar Idriss Abu Garda ${ }^{263}$; Abdallah Banda Abakaer Nourain ${ }^{264}$ e Abdel Raheem Muhammad Hussein ${ }^{265}$;

d) República da África Central: Casos contra Jean-Pierre Bemba Gombo ${ }^{266}$, Aimé Kilolo Musamba, Jean-Jacques Mangenda Kabongo, Fidèle Babala Wandu e Narcisse Arido ${ }^{267}$;

e) República do Quênia: Casos contra William Samoei Ruto e Joshua Arap Sang ${ }^{268}$ e Uhuru Muigai Kenyatta ${ }^{269}$ e Walter Osapiri Barasa ${ }^{270}$;

f) Líbia: Casos contra Muammar Mohammed Abu Minyar Gaddafi, Saif Al-Islam Gaddafi e Abdullah Al-Senussi ${ }^{271}$; e

g) Costa do Marfim: Casos contra Laurent Gbagbo ${ }^{272}$, Simone Gbagbo 273 e Charles Blé Goundé2 ${ }^{274}$.

\footnotetext{
${ }^{255}$ Caso ICC-01/04-01/06

${ }^{256}$ Caso ICC-01/04-02/06

${ }^{257}$ Caso ICC-01/04-01/07

${ }^{258}$ Caso ICC-01/04-02/12

${ }^{259}$ Caso ICC-01/04-01/10

${ }^{260}$ Caso ICC-01/04-01/12

${ }^{261}$ Caso ICC-02/05-01/07

${ }^{262}$ Caso ICC-02/05-01/09

${ }^{263}$ Caso ICC-02/05-02/09

${ }^{264}$ Caso ICC-02/05-03/09

${ }^{265}$ Caso ICC-02/05-01/12

${ }^{266}$ Caso ICC-01/05 -01/08

${ }^{267}$ Caso ICC-01/05-01/13

${ }^{268}$ Caso ICC-01/09-01/11

${ }^{269}$ Caso ICC-01/09-02/11

${ }^{270}$ Caso ICC-01/09-01/13

${ }^{271}$ Caso ICC-01/11-01/11

${ }^{272}$ Caso ICC-02/11-01/11

${ }^{273}$ Caso ICC-02/11-01/11

${ }^{274}$ Caso ICC-02/11-02/11
} 
A Procuradoria do TPI está realizando investigações preliminares em relação a diversas ocorrências reportadas ainda na República Central Africana, Mali, Afeganistão, Geórgia, Guiné, Colômbia, Honduras, Coreia e Nigéria.

\title{
2.5.2 O princípio da complementaridade das jurisdições e sua evolução
}

Os Estatutos dos Tribunais de Ruanda, Iugoslávia, Serra Leoa e Líbano ${ }^{275}$ não afastam as jurisdições locais para julgarem os crimes. Entretanto, no primeiro julgamento do TPII, o tribunal afastou o argumento de que a primazia da corte violava a soberania estatal e os direitos dos acusados, e decidiu que:

\begin{abstract}
"De fato, quando um tribunal internacional como o presente é criado, a ele deve ser atribuída primazia sobre as cortes nacionais. De outra forma, em se tratando de direitos humanos, haveria um perigo perene de os crimes internacionais serem caracterizados como 'crimes ordinários' (Estatuto, art. 10, para. 2(a)), ou de os procedimentos serem 'criados para proteger o acusado', ou de os casos não serem processados de maneira diligente (Estatuto, art. 10, para. 2(b). Não sendo eficientemente definido o princípio da primazia, qualquer desses estratagemas pode ser usado para fulminar o exato propósito da criação de uma jurisdição criminal internacional, em benefício das mesmas pessoas que ele foi criado para processar" 276 .
\end{abstract}

Entretanto, no caso do Estatuto do TPI, estabelece-se claramente a regra da complementaridade do tribunal internacional em relação à jurisdição local, ou seja, as situações específicas nas quais se determinará que o caso é ou não admissível, com base no art. 17.1 do Estatuto. Assim, dispõe o Estatuto:

\footnotetext{
“Art. 17.1. Tendo em consideração o décimo parágrafo do preâmbulo e $\mathrm{o}$ artigo $1^{\circ}$, o Tribunal decidirá sobre a não admissibilidade de um caso se:

a) $\mathrm{O}$ caso for objeto de inquérito ou de procedimento criminal por parte de um Estado que tenha jurisdição sobre o mesmo, salvo
}

\footnotetext{
${ }^{275}$ Artigo 9.1 do TPIR, Artigo 8.1 do Estatuto TPII, Artigo 8.1 do Estatuto do Tribunal de Serra Leoa e Artigo 4.1 do Estatuto do Tribunal do Líbano.

${ }^{276}$ Decisão ao pedido de defesa em recurso interlocutório, Caso Tadic, TPII (IT-94-1-AR72), de 2 de outubro de 1995, § 58, (trad. livre).
} 
se este não tiver vontade de levar a cabo o inquérito ou o procedimento ou, não tenha capacidade para o fazer;

b) O caso tiver sido objeto de inquérito por um Estado com jurisdição sobre ele e tal Estado tenha decidido não dar seguimento ao procedimento criminal contra a pessoa em causa, a menos que esta decisão resulte do fato de esse Estado não ter vontade de proceder criminalmente ou da sua incapacidade real para o fazer;

c) A pessoa em causa já tiver sido julgada pela conduta a que se refere a denúncia, e não puder ser julgada pelo Tribunal em virtude do disposto no parágrafo $3^{\circ}$ do artigo 20;

$$
\text { d) (...)." }
$$

A complementaridade preserva a competência nacional, assegurando-se que o Estado possua capacidade e vontade de julgar o crime, dentro das condições de validade (legalidade, eficácia, legitimidade) que inspiram a redação do art. 17 do TPI, no que DELMAS-MARTY ${ }^{277}$ chama de harmonização indireta dos sistemas penais nacionais ao redor dos critérios internacionais comuns que serão progressivamente explicitados pelo procurador e juízes do TPI, sendo inclusive um dos fatores a facilitar ou pelo menos reduzir as resistências à adesão ${ }^{278}$.

O Art. 17.2 do Estatuto $^{279}$ confere a base normativa para se entender, portanto, o que seja a falta de vontade de processar o caso criminalmente e o art. $17.3^{280}$ para o que seja essa capacidade genuína de processar criminalmente o caso. Procura-se, assim, definir os critérios por meio dos quais o TPI deverá considerar que a justiça local agiu ou estaria agindo, com capacidade para fazê-lo, para processar o acusado ou quando tiver decidido não

${ }^{277}$ DELMAS-MARTY, Mireille. "La CPI et les interactiones entre droit internacional pénal et droit pénal interne à la phase d'ouveture du procès pénal". Revue de Science Criminelle et de Droit Pénal Comparé, $\mathrm{n}^{\circ} 3$, jul/set, 2005, pp. 474-475.

${ }^{278}$ Conforme GRAMMER, Christoph. "El sistema del Estatuto de Roma como fuerza motriz del derecho penal internacional. El inesperado éxito del Estatuto de Roma en América Latina". In: AMBOS, Kai; MALARINO, Ezequiel; WOISCHNIK, Jan (eds.). Temas actuales del derecho penal internacional. Montevideu: Konrad Adenauer, 2005, p. 42

279 Art. 17.2 do ETPI: "A fim de determinar se há ou não vontade de agir num determinado caso, o Tribunal, tendo em consideração as garantias de um processo equitativo reconhecidas pelo direito internacional, verificará a existência de uma ou mais das seguintes circunstâncias: a) O processo ter sido instaurado ou estar pendente ou a decisão ter sido proferida no Estado com o propósito de subtrair a pessoa em causa à sua responsabilidade criminal por crimes da competência do Tribunal, nos termos do disposto no artigo 5o; b) Ter havido demora injustificada no processamento, a qual, dadas as circunstâncias, se mostra incompatível com a intenção de fazer responder a pessoa em causa perante a justiça; c) $O$ processo não ter sido ou não estar sendo conduzido de maneira independente ou imparcial, e ter estado ou estar sendo conduzido de uma maneira que, dadas as circunstâncias, seja incompatível com a intenção de levar a pessoa em causa perante a justiça";

${ }^{280}$ Art. 17.3 do ETPI: "A fim de determinar se há incapacidade de agir num determinado caso, o Tribunal verificará se o Estado, por colapso total ou substancial da respectiva administração da justiça ou por indisponibilidade desta, não estará em condições de fazer comparecer o acusado, de reunir os meios de prova e depoimentos necessários ou não estará, por outros motivos, em condições de concluir o processo". 
processá-lo, restando grande margem de entendimento pela Corte do que seja a capacidade de o Estado julgar o acusado, assim como de ter vontade ou não de processar criminalmente a pessoa, ainda que os arts. 17.2 e 17.3 restrinjam essa avaliação. Nesse sentido, um Estado pode ter vontade, mas suas leis democraticamente aprovadas, podem representar barreiras ao processamento pelo Poder Judiciário (por exemplo, reconhecendo a ilegitimidade das partes, ou a falta de provas, ou o bis in idem, entre outras garantias do processo penal) e o Tribunal, atuando indevidamente como instância revisora, determinar a admissibilidade do caso, julgando, ainda que indiretamente, a própria legislação local. Uma decisão de absolvição, ou de arquivamento, terá, em última instância, que convencer o Tribunal de que ela se sustenta de acordo com os padrões de investigação e de direito aceitos internacionalmente, inclusive com base no direito costumeiro - do contrário, ela não servirá. Tendo atuado de maneira independente e imparcial, com base em sua legislação vigente, dificilmente poderá ter confirmada a competência do TPI diante de uma decisão de não prosseguimento da acusação da justiça local.

O Art. 17.1, na tradução oficial brasileira, omitiu o advérbio "genuinamente", que vem presente na redação original, quando se afirma que o caso será admitido pelo TPI quando o Estado "is unwilling or unable genuinely to carry out the investigations or procesution", ou quando, tendo o Estado arquivado o caso ou absolvido, tiver assim procedido por causa de sua "unwillingness or inability of the State genuinely to prosecute" 281 . O termo "genuinamente", ao mesmo tempo que pode corresponder a uma avaliação subjetiva, procura conferir contornos objetivos aos artigos explicativos, por exemplo, especificamente, se o tribunal local tiver sofrido uma séria destruição, não for possível obter as provas e testemunhas ou conduzir os procedimentos formais.

Para NOUWEN e LEWIS, nos casos previstos no Estatuto, art. 17.3, de colapso do sistema nacional de justiça que cause a incapacidade de conduzir o procedimento, uma avaliação da condição de genuinamente conduzir o processo dificilmente seria necessária. Entretanto, no último caso, de incapacidade em virtude de indisponibilidade de um sistema judicial nacional, alarga-se consideravelmente o escopo da norma e revela-se ser decisivo o

281 Para uma maior reflexão sobre os problemas do plurilinguismo em relação ao ETPI, v. MALARINO, Ezequiel. "Problemas de determinación de la norma penal y soluciones de interpretación en textos penales plurilingües en el ejemplo el Estatuto de Roma". In: AMBOS, Kai; MALARINO, Ezequiel; WOISCHNIK, Jan (eds.). Temas actuales del derecho penal internacional, Montevideu: Konrad Adenauer, 2005, pp. 61-95. 
fator "genuinamente". Mencionam os autores, a esse respeito, a falta de capacidade técnica dos funcionários da justiça, um ambiente inseguro ou a falta de cooperação com outros países, fatores normativos, como a aplicabilidade da anistia ou a imunidade conferida pelas leis locais ou tratados, entre outros, que podem levar um sistema a se tornar indisponível genuinamente para conduzir as investigações. Nesse sentido, um sistema judicial perfeitamente bem estruturado pode ser considerado incapaz ${ }^{282}$, tendo em vista que neste caso em particular, ele não se considera genuinamente disponível para realizar os procedimentos esperados ${ }^{283}$. O elemento "genuinamente" agrega um critério de avaliação que busca evitar a simulação, em referência a procedimentos que sejam eficientes na gestão dos instrumentos judiciais, ainda que por esse critério possa se exercer um ativismo judicial $^{284}$ do qual discordamos por poder ser utilizado em prejuízo da fragmentariedade do direito penal.

Por outro lado, a definição do que seja caso para a competência da corte merece atenção. Conforme apontam NOUWEN e LEWIS ${ }^{285}$, o TPI tem construído sua interpretação do que seja já um caso iniciado pela justiça local, devendo esse caso possuir os exatos mesmos elementos em relação: à mesma pessoa; substancialmente à mesma conduta; aos mesmos incidentes ${ }^{286}$; e, talvez, ao mesmo líder em caso de responsabilidade por comando, em relação à investigação ou ao processo em curso no TPI ${ }^{287}$. Pela adoção de critérios tão

${ }^{282}$ V. TPI, julgamento da apelação de German Katanga contra a decisão oral da Câmara de Julgamento II, de 12 de junho de 2009 sobre a admissibilidade do caso, Caso Katanga e Ngudjolo Chui, República Democrática do Congo (ICC-01/04-01/07-1497), de 25 de setembro de 2009, § 78.

${ }^{283}$ NOUWEN, Sarah; LEWIS, Dustin. "Jurisdictional Arrangements and International Criminal Procedure". Legal Studies Research Paper Series, Univ. Cambridge, Paper n 50/2001, novembro de 2011, p. 15. Também, JAPIASSÚ, Carlos Eduardo Adriano; "O princípio do ne bis in idem no direito penal internacional". Revista da Faculdade de Direito de Campos, Ano IV, $\mathrm{n}^{\circ} 4 \mathrm{e}$ Ano V, nº 5, 2003-2004.

${ }^{284} \mathrm{~A}$ esse respeito, ainda que voltado à situação da Corte Interamericana de Direitos Humanos, os argumentos também servem nesse contexto. MALARINO, Ezequiel. "Activismo Judicial, Punitivización y Nacionalización: Tendencias Antidemocráticas y Antiliberales de la CIDH". In: PASTOR, Daniel R. (dir.). El Sistema Penal en las Sentencias Recientes de los Órganos Interamericanos de Protección de los Derechos Humanos. Buenos Aires: Ad-Hoc, 2010.

285. NOUWEN, Sarah; LEWIS, Dustin. "Jurisdictional Arrangements and International Criminal Procedure", In: SLUITER, Gorang. International Criminal Procedure, Oxford: Oxford University Press, 2011, p. 13.

${ }^{286}$ Conforme decisão sobre a admissibilidade do caso, Caso Saif al-Islam Gaddafi e Abdullah al-Senussi (ICC01/11-01/11 OA 4), de 21 de maio de 2014, § 62, "Incident" is understood as referring to a historical event, defined in time and place, in the course of which crimes within the jurisdiction of the Court were allegedly committed by one or more direct perpetrators". Este caso demonstra a dificuldade de o Estado confirmar a existência de procedimentos internos que afastem a competência do TPI.

${ }^{287}$ Conforme o mandado de prisão contra Lubanga, República Democrática do Congo (ICC-01/04-01/06-8), de 10 de fevereiro de 2006, §§ 31, 39-41; Decisão sobre o pedido de acusação, Caso Harun e Kushayb, Darfur, Sudão (ICC-02/05-01/07-1), de 27 de abril de 2007, § 24; julgamento da apelação da República do Quênia contra a decisão da Câmara de Julgamento Preliminar II sobra a admissibilidade do caso, conforme o art. 
rígidos para se configurar a identidade de casos, pode-se dar margem à violação do princípio do ne bis in idem em direito processual penal julgando o mesmo caso, por se entender que a ausência de alguns dos elementos de definição de caso não são idênticos, remete a competência ao TPI. Há assim o receio de que por conta dessa interpretação, o princípio da complementaridade possa ser flexibilizado, tornando-o mais próximo das práticas relacionadas à primazia da jurisdição internacional penal em relação à local.

19(2)(b) do Estatuto, Caso Ruto, Kosgey e Sang, Quênia, ICC-01/09-01/11, de 30 de agosto de 2011, §§ 3941. 


\subsection{Justiça de Transição}

\subsubsection{Conceito}

Outro mecanismo que acrescentamos ao presente estudo voltado ao processamento de apuração das mais graves violências aos direitos humanos são aqueles desenvolvidos no âmbito da Justiça de Transição. Ao mesmo tempo que se consolida como uma ferramenta para punir a violência maciça durante um período de intenso conflito interno, a Justiça de Transição é uma estratégia a ser adotada para a sustentação da paz local e poderá lançar mão de diversas ações, conforme o contexto e os objetivos que se busquem obter. Ela se localiza a meio caminho entre a escolha indefensável pelo total esquecimento dos fatos gravosos ocorridos e a realização improvável de justiça real ${ }^{288}$. É uma abordagem jurídica, política e social de uma “concepção de justiça associada com períodos de mudança política, caracterizada por respostas legais para confrontar os erros de regimes repressivos anteriores" 289 ou, conforme Paul VAN ZYL, representam o esforço para a construção da paz sustentável após um período de conflito, violência em massa ou violação sistemática de direitos humanos ${ }^{290}$.

A temática da Justiça de Transição abrange tanto os mecanismos judiciariformes mencionados no início deste capítulo, compostos pelos tribunais penais e militares internacionais, como também as estruturas voltadas à reconciliação, descobrimento dos fatos ocorridos nos períodos de exceção ao Estado de Direito, reparação das vítimas e familiares, reformas institucionais, sempre dentro dos padrões internacionais de direitos humanos ${ }^{291}$.

\footnotetext{
${ }^{288}$ Méndez, Juan E. "In defense of transitional justice”, in McAdams, A. James (Ed.), Transitional Justice and the Rule of Law in New Democracies, Univ. Notre Dame Press, Indiana, 2001, pp. 01-26.

289 TEITEL, Rutti G. “Transitional Justice Genealogy”, Harvard Human Rights Journal, vol 162, 2003, p. 69 (trad. livre).

${ }^{290}$ VAN ZYL, Paul. "Dilemmas of Transitional Jusitce: The Case of South Africa's Truth and Reconciliation Commission", 52 J. International Affairs, 647, 1999.

${ }^{291}$ No âmbito das Nações Unidas, o Escritório do Alto-Comando dos Direitos Humanos é o órgão responsável por consolidar estudos e orientações sobre o tema para as missões de paz, citando-se o mencionado relatório (S/2004/616), o relatório do Secretário Geral S/2006/980 - Uniting our strengths: Enhancing United Nations support for the rule of law; a Resolução da Assembleia Geral da ONU (A/RES/60/147) sobre os Princípios Básicos e Orientações sobre o Direito a uma Decisão Judicial e Indenização para as Vítimas de Graves Violações dos Direitos Humanos Internacionais e Graves Violações ao Direito Internacional Humanitário; os
} 
As práticas relacionadas aos preceitos da justiça de transição têm sido saudadas dentro do entendimento de que a redução de impunidade contribui para a reconstrução democrática de estados $^{292}$, representando um "enforque abrangente e multidisplinar que tem por objetivo consolidar importantes valores em sociedades que enfrentam períodos de graves conflitos ou de repressão estatal" ${ }^{293}$.

As origens da Justiça de Transição aparecem ligadas à mesma herança histórica do direito penal internacional, como afirma Cherif BASSIOUNI, em que se buscam o processamento dos graves crimes de efeitos internacionais para além das jurisdições de competência original, territorial. Mas foi somente com as mudanças políticas de 1980, no contexto do enfraquecimento da polarização da Guerra Fria, e a deposição dos regimes políticos, que as forças e o ideal que dão suporte à construção da Justiça de Transição começaram a se popularizar. Nessa época, pairava a dúvida se o modelo de Nuremberg deveria ser seguido ou se deveriam ser buscadas outras formas de tornar transparente os atos praticados pelos regimes nos quais cada vez mais se noticiavam abusos das forças policiais e militares. Fato é que o princípio da responsabilização pelas violências ocorridas passou a ter que conviver com o fato das diversas anistias políticas ${ }^{294}$ concedidas neste período de transição, em que há renúncia à sanção penal para crimes de direito internacional como uma decisão típica na transição de sistemas macrocriminais para um Estado de Direito ${ }^{295}$. Ainda que não exista uma posição clara dentro do direito penal a respeito desse tema, ressalta-se a teoria de que a isenção completa e geral de responsabilidade penal não deve ser admissível diante da obrigação em direito internacional à persecução e sanção penal ${ }^{296}$, tanto quando na

estudos E/CN.4/2004/88 - Promotion and Protection of Human Rights: Impunity; E/CN.4/2005/102/Add.1 Promotion and Protection of Human Rights: Impunity; E/CN.4/2006/91 - Promotion and Protection of Human Rights: Study on the right to the truth; A/HRC/12/18 - Analytical study on human rights and transitional justice.

292 TEITEL, Rutti G. “Transitional Justice Genealogy”, Harvard Human Rights Journal, vol 16, 2003; QUINN, Joanna. Reconciliation(s): Transitional Justice in Postconflict Societies (Studies in Nationalism and Ethnic Conflict), McGill Queen's University Press, 2009, BASSIOUNI, M. Cherif. Introduction to International Criminal Law., Brill: Nijhoff, 2012, entre outros.

${ }^{293}$ ZILLI, Marcos. "Punir or not punir? Qual é o verdadeiro dilema?”, Revista Anistia 9, p. 340.

294 Para os temas da anistia na África do Sul, v. Paul VAN ZYL, "Dilemmas of Transitional Jusitce: The Case of South Africa's Truth and Reconciliation Commission”, 52 J. International Affairs, 647, 1999.

${ }^{295}$ V. WERLE, Gerhard. Tratado de DPI, op. cit., p. 135.

${ }^{296}$ Nesse sentido, v. Final Report on the Exercise of Universal Jurisdiction in Respect of Gross Human Rights Offenses, Londres, 2000, da International Law Association, art. 10 do Estatuto do Tribunal Especial de Serra Leoa (UN/DOC S/2000/915, anexo: "A anistia concedida a uma pessoa a respeito da qual o Tribunal Especial tenha competência em relação a [crimes de lesa humanidade, infrações ao art. $3^{\circ}$ comum, outras infrações graves do direito internacional humanitário] não constituirão um impedimento para o processamento" (trad. livre). Também o Princeton Project on Universal Jurisdiction, "1. Anistias são em geral inconsistentes com a 
vigência do Estado de Direito, diante da expectativa por parte da comunidade internacional de que os fatos criminosos não sejam esquecidos e seus agentes não permaneçam impunes ${ }^{297}$. O fato inescapável e que apresenta a grande dificuldade jurídica e em relações internacionais é a de que a anistia pode ser um instrumento para se conseguir a paz e, nesses casos, o desrespeito à anistia firmada por um governo sob a alegação de que ela não obriga a comunidade internacional parece um argumento torto ${ }^{298}$. De toda forma, independentemente do recurso à via persecutória, as diferentes experiências em Justiça de Transição têm demonstrado a importância de medidas que contribuam à construção da memória histórica, à depuração da máquina administrativa estatal, à renovação do sistema judiciário e reconstrução de instituições pós-conflito baseadas no respeito ao estado de direito, e à indenização das vítimas e seus familiares ${ }^{299}$.

O processamento destes crimes em contexto de transição política ocorreu principalmente por meio das comissões de verdade, definido como um órgão oficial, geralmente criado por um governo nacional para investigar, documentar e relatar abusos de direitos humanos ocorridos num intervalo certo de tempo passado dentro de um país ${ }^{300}$, em geral com uma dimensão política tendo por metodologia principal a investigação de padrões de abusos ao invés de fatos isolados dentro de uma pauta ou programa de ação específica. Os processamentos ocorrem tendo por escopo os efeitos na comunidade, inclusive abordando os fatos de maneira coletiva, ao invés do modelo individualizado próprio da justiça penal, que enfatize mais a busca da pacificação social a partir da narrativa e revelação dos fatos e que propiciasse uma reconciliação do passado com o presente, e menos concentrado na punição específica dos agentes. Abaixo, indicamos as comissões de verdade ao redor do mundo ocorridas até o presente:

\footnotetext{
obrigação dos Estados de apurar e atribuir responsabilidade por [crimes de guerra, crimes contra a paz, crimes contra a humanidade, genocídio...]" (trad. livre).

${ }^{297}$ ZILLI, Marcos. "Punir or not punir? Qual é o verdadeiro dilema?”, in Revista Anistia 9, p. 340.

${ }^{298}$ Nesse sentido, a posição de GIL GIL, Alicia, em relação ao processo de transição na Espanha. A autora entende que a Ley de Amnistía, de 1977, não foi contrária ao direito internacional vigente à época, assim como não considera incoerente o seu país perseguir crimes cometidos em outros países desconhecendo a lei de anistia lá vigentes (caso Pinochet), enquanto não persegue os fatos cometidos na Espanha e cobertos pela anistia espanhola. Isso porque, entende GIL GIL, que diante da separação de poderes, não há que se cobrar coerência de poderes independentes entre si, desde que sejam decisões jurídicas corretas. Para a autora, "el modelo español de justicia de transición ha sido un modelo de olvido absoluto con rehabilitación parcial; un modelo fruto de la necesidad y la conyuntura política y social en el que se desarrolló". GIL GIL, Alicia. "Espanha". In: AMBOS, Kai; MALARINO, Ezequiel; ELSNER, Gisela. Justicia de transición: con informes de América Latina, Alemania, Italia y España, Konrad-Adenauer Stiftung, Montevidéu, 1996, p. 496-497.

${ }^{299}$ ZILLI, Marcos. "Punir or not punir? Qual é o verdadeiro dilema?”, Revista Anistia 9 , p. 342.

300 TEITEL, Rutti. “Transitional Justice Genealogy”, op. cit., 2003, p. 78
} 


\begin{tabular}{|c|c|c|}
\hline Argentina & 1983 & Comisión Nacional para la desaparición de personas \\
\hline Uganda & 1986 & $\begin{array}{l}\text { Commission of Inquiry into Violations of Human } \\
\text { Rights }\end{array}$ \\
\hline Nepal & 1990 & $\begin{array}{l}\text { Commission of Inquiry to find the Disappeared } \\
\text { Persons during the Panchayat Period }\end{array}$ \\
\hline Chile & 1990 & $\begin{array}{l}\text { Comisión Nacional para la Verdad y la } \\
\text { Reconciliación }\end{array}$ \\
\hline Alemanha & 1992 & $\begin{array}{l}\text { Komission auf Arbeitung von Gestichte und Folgen } \\
\text { der SED-Diktatur in Deutschland }\end{array}$ \\
\hline El Salvador & 1992 & Comisión de la Verdad \\
\hline Sri Lanka & 1994 & $\begin{array}{l}\text { Commission of Inquiry into the Involuntary } \\
\text { Removal of Disappearence of Persons }\end{array}$ \\
\hline Haiti & 1995 & Commission Nationale de la Verité et Justice \\
\hline $\begin{array}{l}\text { República } \\
\text { Tcheca }\end{array}$ & 1995 & $\begin{array}{l}\text { Office for the Documentation and the Investigation } \\
\text { of the Crimes of Communism }\end{array}$ \\
\hline South Africa & 1995 & Truth and Reconciliation Commission \\
\hline Guatemala & 1997 & Commission para el esclarecimiento histórico \\
\hline Nigéria & 1999 & $\begin{array}{l}\text { Judicial Commission of Inquiry for the Investigation } \\
\text { of Human Rights Violation }\end{array}$ \\
\hline Coreia do Sul & 2000 & $\begin{array}{l}\text { Presidential Truth Commission on Suspicious } \\
\text { Deaths }\end{array}$ \\
\hline Uruguai & 2000 & Comisión de la Paz \\
\hline Panamá & 2001 & Comisión de la Verdad \\
\hline Peru & 2001 & Comisión de la Verdad y Reconciliación \\
\hline Granada & 2001 & Truth and Reconciliation Commission \\
\hline
\end{tabular}




\begin{tabular}{|c|c|c|}
\hline Iugoslávia & 2001 & Truth and Reconciliation Commission \\
\hline Timor Leste & 2002 & $\begin{array}{l}\text { Commission for the Reception, Truth and } \\
\text { Reconciliation }\end{array}$ \\
\hline Gana & 2002 & National Reconciliation Commission \\
\hline Serra Leoa & 2002 & Truth and Reconciliation Commission \\
\hline Marrocos & 2004 & Instance Équité et Réconciliacion \\
\hline Paraguai & 2004 & Comisión de Verdad y Justicia \\
\hline Congo & 2004 & Comission de Verité et Réconciliacion \\
\hline Liberia & 2005 & Truth and Reconciliation Commission \\
\hline Fiji & 2005 & Reconciliation and Unity Commission \\
\hline Ucrânia & 2006 & Ukrainian National Remembrance Institute \\
\hline Indonesia & 2007 & Truth and Reconciliation Commission \\
\hline Ecuador & 2007 & Comisión de la Verdad \\
\hline Quênia & 2008 & Truth, Justice and Reconciliation Commission \\
\hline Canadá & 2008 & $\begin{array}{l}\text { Indian Residential Schools Truth and Reconciliation } \\
\text { Commission }\end{array}$ \\
\hline Ilhas Salomão & 2009 & Truth and Reconciliation Commission \\
\hline Brasil & 2011 & Comissão Nacional da Verdade \\
\hline
\end{tabular}

O tema fez parte do relatório do Secretário Geral da ONU intitulado "The rule of law and transitional justice in conflict and post-conflict societies" ${ }^{\prime 01}$, no qual se reconhece a importância dos tribunais internacionais e o seu valor na reconstrução de sociedades após o conflito. Entretanto, são reconhecidamente mecanismos caros e que pouco contribuem diretamente para os sistemas formais locais de administração da justiça. O relatório aborda

${ }^{301}$ Doc. ONU S/2004/616, de 23 de agosto de 2004. 
o tema da justiça de transição também sob a ótica da complementaridade das comissões de direitos humanos no restabelecimento do Estado de Direito, como forma de resolução pacífica e proteção dos grupos vulneráveis onde o sistema de justiça não estiver completamente em funcionamento. Sobretudo, traça programas para a reconstrução e administração dos sistemas judiciários locais que se pautem pelos patamares de respeito aos direitos humanos, trazendo para o plano local as capacidades institucionais de processamento segundo as regras do Estado de Direito, integrado a ações voltadas ao desarmamento, desmobilização e reintegração de ex-combatentes, assim como facilitação do retorno das populações deslocadas. Estes programas, por sua vez, não apenas servem para atuar no plano formal do Estado, como também para apoiar as ações das comissões de reconciliação e verdade.

\subsubsection{Direito à Verdade, Anistia e o Direito Penal para a Justiça de Transição}

Precisamos refletir sobre o papel do direito penal em relação à justiça de transição pelo diálogo que se estabelece entre eles, tanto como complementaridade, quanto por se verificar que por muitos motivos suas formas de atuação opõem-se. O direito penal está subjacente à prática da justiça de transição, podendo confirmar ou atribuir punições próprias do direito penal ou, alternativamente a ele, criar formas de reparação ou superação dos fatos delitivos apurados. Como forma de tratamento social dos mais graves crimes, que é o epicentro das violações severas aos direitos humanos, a própria justiça penal apresenta suas limitações, inclusive a própria debilidade das instituições que deve exercer o poder punitivo estatal diante do poder que sustentava o antigo regime deposto e a construção de um ambiente de paz e convivência social. Em outra medida, a perspectiva da punição, pela via do direito penal, tem sido realçada como uma das principais ferramentas para o enfrentamento do passado, ensejando, no entendimento da Corte Interamericana de Direitos Humanos, relativamente à situação vivida durante as ditaduras na América Latina, uma jurisprudência que reafirma o dever de punição, "incompatível com os instrumentos jurídicos consagradores da impunidade, como a anistia e a prescrição"302.

${ }^{302}$ ZILLI, Marcos. "Punir or not punir? Qual é o verdadeiro dilema?”, in Revista Anistia, vol. 9, p. 351. 
Atualmente o direito penal internacional, com esforços concentrados nos procedimentos dos tribunais ad hoc e o TPI, ainda se vê envolvido com questões bastante complexas do ponto de vista sociológico, como aqueles ligados a costumes e sociedades tradicionais, com regras e formas de resolver seus conflitos de maneira às vezes contrárias ao direito ocidental. Em suas categorias, tanto com relação ao sistema da Gacaca, de Ruanda $^{303}$, ou o direito tradicional do Timor Leste, ou como o sistema Mato Oput de Uganda, o direito penal sofre o questionamento de sua validade e império para resolver o problema do crime em qualquer sociedade. A afirmação abaixo do bispo local em Uganda é emblemática:

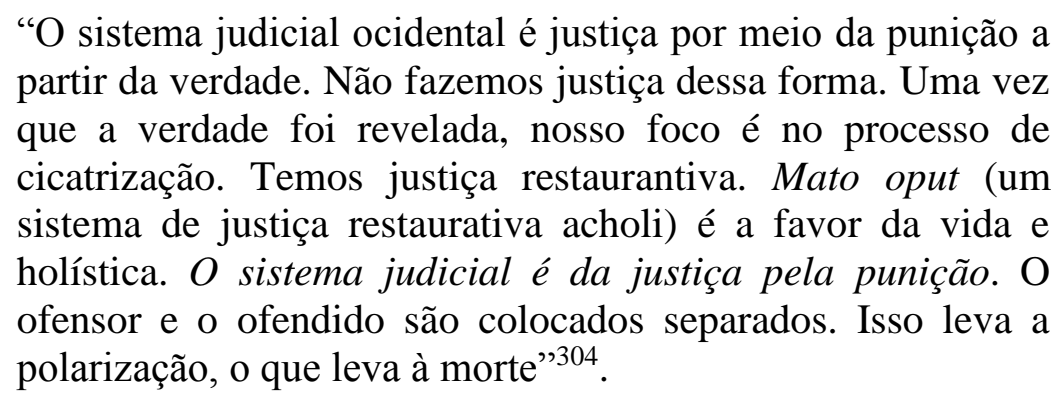

Como se nota, a existência das comissões da verdade representa um papel contraditório, numa busca da verdade fora das instituições de justiça formal: revelam uma verdade sem punir. FREEMAN ${ }^{305}$, por exemplo, questiona o exercício das comissões da verdade com base nas seguintes afirmações: as comissões possuem uma função investigadora embora não tenham poderes de decisão, o que permite diferenciá-las dos órgãos judiciais; são órgãos voltados às vítimas; e não se limitam a revelar fatos mas realizam o relato das causas e consequências dos fatos.

Há que se ter em conta, ainda, que a verdade não é um bloco monolítico, mas uma referência em que se encontram subjetividades e a diversidade das perspectivas e experiências sobre o mesmo fato. O próprio reconhecimento pela Comissão e Corte Interamericana de Direitos Humanos do papel relevante das Comissões da Verdade na

\footnotetext{
${ }^{303}$ Relatório "Rwanda Gacada: a question of justice". Amnesty International, 17 de dezembro de 2002.

${ }^{304}$ Entrevista realizada por NOUWEN, Sarah, citado por ela. "Justifying justice". In: CRAWFORD, James; KOSKENNIEMI, Martii. The Cambridge Companion to International Law, Cambridge: Cambridge Univ. Press, 2012, p. 332.

${ }^{305}$ FREEMAN, "Truth Commissions and Procedural Fairness", Cambridge, U.P., 2006, p. 3.
} 
cristalização de uma "verdade histórica", mas que deve ser buscada ao lado da "verdade jurídica", remonta ao reconhecimento de que existem diversas "verdades" 306 , promovendo em diversos casos o "refazimento da verdade" 307 , a demonstração que a verdade oficial não é uma verdade que se sustenta em vista dos elementos trazidos pela reconstrução dos fatos contados pelos lados contrapostos.

A verdade que se busca, assim, não deve ser a verdade filosófica para que se atinja a plena virtude e o conhecimento de todos os detalhes das execuções do plano político e atos de violações aos direitos humanos por trás, mas que seja um processo de revelação e construção social dos fatos, possibilitando à vítima a reparação moral e elaboração psíquica buscada, mas especialmente o reconhecimento pelo Estado de que sob suas ordens, de um Estado autoritário e em regime de exceção, os direitos de cidadãos foram violados de maneira sistemática, da qual sobressai um mandamento histórico: esses fatos não podem voltar a ocorrer. O foco central do trabalho das comissões é, portanto, encontrar um mínimo denominador comum em relação à parte essencial da história, uma revelação que ponha fim a uma etapa caracterizada essencialmente pela ocultação e sistemática manipulação da versão oficial. É, conforme TAMARIT SUMALLA ${ }^{308}$, uma verdade democrática, conquistada e emancipadora, não uma verdade autoritária produzida pelo discurso oficial: a verdade produzida no contexto de uma comissão da verdade tem condições de ser compatível com o pluralismo político e cultural, e com liberdade de investigação, além disso, nos casos em que as anistias não puderem ser revogadas, não soçobra em cima de responsabilidade criminal. Ainda que imperfeito, trata-se de um mecanismo que melhor responde ao processo de restabelecimento de uma ordem democrática, ao contrário do que se pretendia estabelecer com o absoluto esquecimento, quando o conhecimento do passado representasse um tabu, dentro dos "projetos de esquecimento".

\footnotetext{
${ }^{306}$ Consoante a decisão do caso Gomes Lund v. Brasil, ao afirmar que o papel da Comissão Nacional da Verdade pode contribuir para a construção e preservação da memória histórica, e o esclarecimento de fatos e a determinação de responsabilidades institucionais, sociais e políticas, embora os elementos trazidos por este tipo de trabalho não possam se substituir "à obrigação do Estado de estabelecer a verdade e assegurar a determinação judicial de responsabilidades individuais, através dos processos judiciais penais". Corte IDH, Gomes Lund e outros v. Brasil, (Guerrilha do Araguaia), 24 de novembro de 2010, Série C 219, § 297.

${ }^{307}$ Em referência ao trabalho da Comissão Especial de Reconhecimento dos Mortos e Desaparecidos Políticos por seu presidente à época, REALE JR., Miguel. "A Comissão Especial de Reconhecimento dos Mortos e Desaparecidos Políticos”. In: TELES, Janaína. Mortos e Desaparecidos Políticos: Reparação ou Impunidade?, São Paulo: Humanitas, 2001, pp. 206-207.

308 TAMARIT SUMALLA, Josep. "Justicia penal, justicia reparadora y comisiones de la verdad", In: TAMARIT SUMALLA, Josep (coord.). Justicia de transición, justicia penal internacional y justicia universal, Atelier, 2010, p. 49.
} 
O fato de se recordar, reconhecer e declarar a verdade para o mundo por meio de um processo oficial tem sido importante por razões que tem menos que ver com a punição dos indivíduos e mais pelo processo curativo das feridas. Percebido como um importante passo para se buscar um recomeço a partir da cicatrização das feridas, entende-se que as condições para a recuperação de um trauma presente e da perspectiva de restauração da dignidade da vítima estão ligadas a esse processo. Enfrentar os acontecimentos, produzir a memória e possibilitar que essa seja contada com reconhecimento das violações perpetradas permite à comunidade fragmentada recriar condições de uma vida social viável ${ }^{309}$.

O direito à verdade tem sido reconhecido principalmente no âmbito do sistema de proteção latino-americano dos direitos humanos, pela Corte Interamericana de Direitos Humanos (CorteIDH) e pela Comissão Interamericana de Direitos Humanos (ComIDH), mesmo diante da ausência de previsão expressa a esse direito na Convenção Americana, mas fruto de uma interpretação dinâmica do tratado pelos seus órgãos, inclusive podendo ter contribuído à consagração deste direito por um tratado da ONU (a Convenção das Nações Unidas para a proteção de todas as pessoas contra o desaparecimento forçado, preâmbulo e art. $\left.24, \S 2^{\circ}\right)^{310}$. A ComIDH, por meio do Informe 25/98, em relação ao Chile, entende que o direito à verdade é independente do direito à reparação e punição, e que assiste à toda sociedade e especialmente à família conhecer a verdade do ocorrido, para evitar o seu cometimento futuro, como decorrência dos artigos 8-1 e 25 da Convenção Americana de Direitos Humanos - $\mathrm{CADH}^{311}$ que tratam do direito a toda pessoa de ser ouvida por um juiz ou tribunal, bem como a poder recorrer a eles de modo rápido para a proteção de atos ou violem seus direitos fundamentais, mesmo que a violação tenha sido cometida por pessoas atuando no exercício de suas funções oficiais. A verdade, nesse sentido, somente se atingiria pela garantia da liberdade de expressão, realização de investigações, e atribuição dos meios necessários especialmente no âmbito do Poder Judiciário, conforme o direito interno de cada

\footnotetext{
${ }^{309}$ VERHOEVEN, J. "Vers um ordre répressif universel?", AFDI, 45, 1999, pp. 55 ss.

310 MARTIN-CHETNUT, Kathia. "Direito à verdade e justiça de transição: a contribuição do sistema interamericano de proteção dos direitos humanos", Revista Anistia, 9, p. 198.

311 Conforme relacionado no Informe $21 / 2000$ da ComIDH. Também o Informe Anual da ComIDH, 1985 1986, OEA/Ser.L/V/II.68, Doc., 8, rev. 1, 26 de setembro de 1986, Cap. V, pág. 205, afirmando que "Toda sociedad tiene el irrenunciable derecho de conocer la verdad de lo ocurrido, así como las razones y circunstancias en las que aberrantes delitos llegaron a cometerse, a fin de evitar que esos hechos vuelvan a ocurrir en el futuro".
} 
país ${ }^{312}$, isso porque "o processo destinado a estabelecer a verdade requer o livre exercício do direito de buscar e receber informação e a adoção das medidas necessárias para habilitar o Poder Judiciário a empreender e completar as investigações correspondentes" ${ }^{\text {"313. }}$

No âmbito das Nações Unidas, o Comitê de Direitos Humanos estabeleceu também, com relação à violação do direito à vida, que os seus familiares tem direito à indenização e ao conhecimento das circunstâncias da morte e dos responsáveis pelo crime ${ }^{314}$, insistindo que o dever de reparar o dano não se satisfaz somente com o oferecimento de indenizações em dinheiro, mas que o primeiro passo é colocar fim ao estado de incerteza e ignorância em que se encontra, ou seja, fornecer o conhecimento completo e público da verdade $^{315}$. O Comitê também entendeu que os titulares do direito à verdade são, ao lado dos familiares, a sociedade em geral $^{316}$.

Por outro lado, questiona-se o uso da expressão "verdade", com uma natureza quase mitológica, utilizando-se ou percebendo-se o quanto produzido pelas Comissões da Verdade como projetos autoritários e que busquem encontrar verdades absolutas buscadas a qualquer preço, preferindo-se o uso da expressão “direito à informação", pois para PASTOR, com o uso de valores tão elevados e indiscutíveis como a verdade (assim como a igualdade, a justiça) quer-se "encobrir com sua autoridade um seguro abuso do que se faz em seu nome" ${ }^{317}$. Ainda que se corra o risco de se revolver as feridas, e de que em nome do direito à verdade ou à informação cometam-se abusos, em relação ao próprio direito penal mínimo, a superação da versão oficial que encoberta graves violações aos direitos humanos e ao

\footnotetext{
${ }^{312}$ CorteIDH, Informe Anual 1985 - 1986- OEA/Ser.L/V/II.68, Doc. 8 rev. 1, p. 205.

${ }^{313}$ Conforme o Informe sobre a Colômbia, "Verdad, justicia y reparación: Cuarto informe sobre la situación de derechos humanos en Colombia", OEA/Ser.L/V/II, Doc. 49/13, de 31 de dezembro de 2013.

${ }^{314}$ CDH-ONU, Caso No 107/1981, Elena Quinteros Almeida e María del Carmen Almeida de Quinteros contra Uruguay, Casos Nos. 146/1983 e 148-154/1983, Johan Khemraadi Baboeram e outros c. Suriname, Caso $\mathrm{N}^{\circ}$ 161/1983, Joaquín David Herrera Rubio c. Colombia, Caso No 181/1984, A. e H. Sanjuán Arévalo c. Colombia. 315 Theo VAN BOVEN, Relator Especial, Comissão de Direitos Humanos, Nações Unidas, Estudio relativo al derecho de restitución, indemnización y rehabilitación a las víctimas de violaciones flagrantes de los derechos humanos y las libertades fundamentales, Conselho Econômico e Social, Subcomissão de Prevenção a Discriminações e Proteção às Minorias, 45 período de sessões, E/CN.4/Sub.2/1993/8, 2 de julho de 1993. Nesse sentido se pronunciam, também, outros relatores especiais sobre a materia, cf. L. JOINET, "Question of Impunity of perpetrators of Violations of Human Rights (Civil and Political Rights)", Relatório Final conforme a Resolução da Subcomissão 1995/35, Doc. ONU, E/CN.4/Sub.2/1996/18 (1996).

${ }^{316}$ ComIDH, informe $n^{\circ} 1 / 99$, caso no 10.480 , Lucio Parada Cea e outros contra El Salvador, 27 de janeiro de 1999, par. 152. Anistia Internacional, Peace-Keeping and Human Rights, AI Doc. IOR 40/01/94 (1994), página 38 Comissão Internacional de Juristas, Comunicación escrita presentada a la Subcomisión de Prevención de Discriminaciones y Protección a las Minorías, 44 período de sessões, E/CN.4/Sub.2/1992/NGO/9.

317 PASTOR, D.R. "Procesos penales sólo para conocer la verdad? La experiência argentina", In: EIROA, Otero (Coord.), Memoria y derecho penal, Buenos Aires, 2008, p. 393-399.
} 
princípio do Estado de Direito, representa uma forma o exercício de um dos atributos da dignidade humana e restabelecimento do estatuto de cidadania, inclusive com a carga emotiva, mistificada por trás da expressão "verdade"318.

O direito penal deve refletir sobre o debate em torno das anistias concedidas e o aparente dilema que se coloca, diante do fato de que as transições ocorrem resultado de negociações nas quais o processamento criminal entra como moeda de troca para sua concessão, como condição para a aceitação da nova ordem política, representando a anistia, assim, uma ferramenta para se conseguir a transformação política almejada. O aparente dilema seria o seguinte: a busca da paz e reconciliação é compatível com a busca por justiça? Considerando-se, então, que justamente os altos comandos que podem firmar a paz são os mesmos a figurar como altos escalões responsáveis pelos crimes ocorridos, essa negociação teria por objetivos principais uma dupla implicação: a) permitir uma transição pacífica a um novo regime; b) garantir que não haja punição pelas violações ocorridas para a manutenção do regime de exceção. Uma possível resposta seria a de que somente casos de paz não negociada, não haveria a concessão de anistias e os responsáveis seriam julgados criminalmente. Em todo o caso, a auto-anistia aparece como o grande tema a posicionar o debate, pois é um desvirtuamento do próprio conceito esquecimento, embutido na anistia: o governante escolhe o que esquecer, mas não pode impor que ele seja esquecido ${ }^{319}$.

No caso brasileiro, a anistia foi concedida por meio de lei do Congresso Nacional $^{320}$, Lei 6.683/1979, de natureza política e jurídica, que exclui a punibilidade dos crimes políticos e $\operatorname{conexos}^{321}$. A legalidade da lei de anistia brasileira foi discutida paralelamente em duas instâncias: na CIDH e pelo Supremo Tribunal Federal, por meio da ADPF 153, ajuizada pelo Conselho Federal da OAB. O entendimento do STF foi o de que a Lei de Anistia não deveria ser revogada, conforme voto do Min. Eros Grau, em julgamento no dia 27 de abril de 2010, em vista, entre outros argumentos, de esta ter ocorrido mediante

\footnotetext{
318 TAMARIT SUMALLA, Josep, op. cit., p. 53.

319 AMBOS, Kai; ZILLI, Marcos; ASSIS MOURA, Maria Thereza; MONTECONRADO, Fabíola Girão. Anistia, Justiça e Impunidade - reflexões sobre a Justiça de Transição no Brasil. Belo Horizonte: Ed. Fórum, 2010, pp. 186-187. AGUILAR, Francisco. Amnistia e constituição. Coimbra: Almedina, 2004.

${ }^{320}$ Conforme art. 43, VIII, da Constituição da República Federativa do Brasil de 1969.

${ }^{321}$ A lei foi reproduzida na Emenda Constitucional no 26, que convocou a Assembleia Nacional Constituinte: “Art. $4^{\circ}$ É concedida anistia a todos os servidores públicos civis da Administração direta e indireta e militares, punidos por atos de exceção, institucionais ou complementares. $\S 1^{\circ}$ É concedida, igualmente, anistia aos autores de crimes políticos ou conexos, e aos dirigentes e representantes de organizações sindicais e estudantis $(\ldots)$ ".
} 
acordo político, firmada por ato do Congresso Nacional e integrada à Constituição por Emenda Constitucional 26/85 que convocou a Assembleia Constituinte ${ }^{322}$. Pairava, não obstante, a dúvida de que, confrontando o art. $5^{\circ}, \S .3^{\circ}$, por meio da Emenda Constitucional 45, que atribui aos tratados de direitos humanos, aprovados em regime especial de votação, o nível constitucional.

A ComIDH, em 24 de novembro de 2010, entendeu que "as disposições da Lei de Anistia brasileira que impedem a investigação e sanção de graves violações de direitos humanos são incompatíveis com a Convenção Americana, carecem de efeitos jurídicos e não podem seguir representando um obstáculo para a investigação dos fatos do presente caso, nem para a identificação e punição dos responsáveis, e tampouco podem ter igual ou semelhante impacto a respeito de outros casos de graves violações de direitos humanos consagrados na Convenção Americana ocorridos no Brasil”323. Diante da desarmonia, permanecemos no ambiente da força do real: as instituições tornaram-se democráticas, dificilmente podendo-se pensar num retrocesso que possa se parecer com o que houve no período de exceção, uma Comissão de Anistia ${ }^{324}$ operante no âmbito do Ministério da Justiça que avalia e concede indenizações às vítimas da ditadura, uma Comissão Nacional da Verdade que produziu um relatório contundente ${ }^{325}$ e aclamado $^{326}$ e poucas condições jurídicas de se legitimar uma punição pela violação dos direitos dos torturadores (que também titulam direitos).

Apesar das anistias que ocorreram em diversos países do mundo, houve diversos casos em que as Nações Unidas apoiaram o processo de concessão de anistia como meio para se restaurar a paz e a transição para um governo democrático ${ }^{327}$. De modo geral, as

\footnotetext{
${ }^{322}$ Críticas à decisão do STF, v. RAMOS, André de Carvalho. "Crimes da ditadura militar: a ADPF 153 e a CorteIDH". In: GOMES, Luis Flávio; MAZZUOLI, Valério de Oliveira. Crimes da ditadura militar. Uma análise à luz da jurisprudência atual da CorteIDH. São Paulo: Ed. Revista dos Tribunais, 2011.

${ }^{323}$ Caso Gomes Lund e outros v. Brasil (Guerrilha do Araguaia), CorteIDH.

${ }^{324}$ Instalada pelo Ministério da Justiça, no dia 28 de agosto de 2001 e criada pela Medida Provisória $\mathrm{n}^{\circ} 2.151$, tem por objetivo analisar os pedidos de indenização formulados pelas pessoas que foram impedidas de exercer atividades econômicas por motivação exclusivamente política desde 18 de setembro de 1946 até cinco de outubro de 1988.

${ }^{325}$ V. site da Comissão Nacional da Verdade, www.cnv.br.

${ }^{326}$ Notícia no jornal Folha de S. Paulo: "Relatório Final da Comissão da Verdade é notícia internacional" (disponível em: http://www1.folha.uol.com.br/poder/2014/12/1560730-relatorio-final-da-comissao-daverdade-e-noticia-internacional.shtml. Acesso 10.11.2014).

${ }^{327}$ Faz-se referência aos processos de transição apoiados pela ONU em relação a anistias em El Salvador, Camboja e na África do Sul. Cf. Report of the United Nations Truth Commission for El Salvador, From Madness to Hope: the 12-year war in El Salvador, ONU Doc. S/25500 (1993); de ETCHESON, Craig, After
} 
anistias não são nem proibidas nem permitidas no âmbito do direito internacional, apesar de uma exceção, prevista no Protocolo Adicional II, art. 6.5, à Convenção de Genebra de 1949, prevendo que ao final das hostilidades deve-se conceder anistias de forma ampla a todos que participaram do conflito. Mas não se entende que isso seja uma permissão a anistias de forma ampla, mas apenas a que os combatentes não sejam punidos por terem realizado atos nos combates e que representem crimes ordinários ${ }^{328}$.

Questionando-se se o direito internacional proíbe anistias diante da responsabilidade individual por crimes perpetrados durante conflito, BROOMHALL pondera se é verdade que diante da obrigação de proteção dos direitos humanos deve haver a obrigação de processar criminalmente, ou seja, que a obrigação de processar é absoluta ${ }^{329}$. A esse respeito, sustenta o autor que em casos onde um grupo não está numa posição de impor um programa rigoroso de punição, como em Nuremberg, no qual dois grupos devem continuar a conviver juntos numa sociedade, a melhor visão é uma mais nuançada. A obrigação de adotar um processamento criminal significativo não deve ser completamente posta de lado, mas nesse contexto, pode haver espaço para uma flexibilização desta obrigação, especialmente se a indenização e respeito à dignidade das vítimas for reconhecida. É possível, na opinião de BROOMHALL, que um reconhecimento adequado das violações, indenização e esforços para reformas institucionais e de boa fé possam tornar aceitáveis o não processamento criminal dos indivíduos por meio do sistema de justiça criminal.

Em todo caso, essa situação ainda resulta frágil diante das perspectivas das teorias que sustentam a obrigação de punir, do direito costumeiro e da jurisdição universal que ainda alguns países chegam a defender. Diante da vigência do Estatuto de Roma, bem como do teor do Anteprojeto de Lei de Implementação do Estatuto de Roma ao direito brasileiro, não poderá mais haver anistia aos crimes que se encontram sob a competência do

the killing fields: lessons from the Cambodia genocide, Greenwood Publishing Group, 2005; JOYNER, C., "Reigning Impunity for International Crimes and Serious Violations of Fundamental Human Right: Proceedings of the Siracusa Conference", 1998, Nouvelles Études Pénales, pp. 225-227; Truth and Reconciliation Commission of South Africa Report (5 vols.), Londres: Macmillan, 1998.

${ }^{328}$ Carta de Toni PFANNER, Diretor Jurídico, ICRC, citado em BASSIOUNI, M. Cherif; MORRIS, Madeleine (eds.). Accountability for International Crimes and Serious Violations of Fundamental Human Rights, 1996, p. 218.

${ }^{329}$ BROOMHALL, Bruce. International Justice \& the ICC - between sovereignty and the rule of law. Oxford: Oxford Univ. Press, 2004, pp. 96 ss. 
TPI, pois o art. $3^{\circ}$ assim o prevê, assim como a Constituição Federal, no art. $5^{\circ}$, XLIII, já prevê que as práticas de tortura (...), e os definidos como crimes hediondos" são insuscetíveis de anistia, graça ou indulto ${ }^{330}$.

A dificuldade é a de se encontrar o padrão de legalidade punitiva a prevalecer no curso do processo encetado. A relação da justiça de transição, por meio do trabalho das comissões de verdade, e o direito penal diante das leis de anistia pode se desenvolver sob três principais modelos:

a) Independência:

Nesses casos, a anistia concedida não é revista, por motivos como: a justiça penal pode ser um elemento de desestabilização interna ou porque o modelo constitucional e sua interpretação atual não permite essa revisão. Dentro deste modelo, prevalece o entendimento de que a anistia fora concedida dentro de um acordo político, e que a revisão implicaria olhar os fatos passados sob uma ótica fora de seu tempo, e que sua revisão revolveria temas já acomodados numa ordem constitucional democrática, que não permite a retroação da lei penal, como por exemplo, o caso da transição democrática na Espanha.

Essa situação também foi colocada no Caso Gelman v. Uruguai ${ }^{331}$, quando, apesar da consulta popular levada a cabo em 2009, confirmando a vontade do povo uruguaio de não rever o alcance da lei de 1986 (ley de caducidade), a Corte considerou que "o fato de que a ley de caducidad tenha sido aprovada por um sistema democrático e tenha recebido, ainda, apoio popular por duas vezes, não lhe confere, nem automaticamente, nem por si só, legitimidade em direito internacional" ${ }^{332}$. Ou seja, ainda que fruto de um possível acordo de vontades para o esquecimento dos fatos puníveis, ou de uma reafirmação popular desse acordo, baseado na vontade que sobressai da população, não afasta o fato de se tratar de uma medida tomada em regime de exceção, contrário ao compromisso de defesa e garantia dos direitos humano, no âmbito do sistema latino-americano de direitos humanos.

\footnotetext{
${ }^{330}$ Conforme JAPIASSÚ, Carlos Eduardo Adriano. O direito penal internacional. Belo Horizonte: Ed. Del Rey, 2009, p. 124.

331 Tanto quanto no caso Gomes Lund e outros contra Brasil (Guerrilha do Araguaia), Corte IDH, 24 de novembro de 2010, Série C 219.

${ }^{332}$ CorteIDH, Gelman v. Uruguai, 24 de fevereiro de 2011, série C 221, § 238.
} 
b) Complementaridade:

Nesses casos, as duas instâncias processam as violações de acordo com seus métodos, separadamente mas buscando as respostas institucionais (do aparado judicial ou práticas de justiça restaurativas) às violações ocorridas. No âmbito judicial, prevalece o interesse na atribuição da responsabilidade penal, movimentando as instituições da justiça penal. Pode ser necessário, nesses casos, o recurso ao costume internacional, mesmo na ausência de dispositivos legais típicos, invocando-se, conforme apontado por ZILLI ${ }^{333}$, um padrão internacionalmente aceito para se identificar um grupo de condutas como puníveis e que, diante de práticas tão atrozes, não seria possível falar-se em ausência de mandamento proibitivo ou mesmo na aplicação dos institutos despenalizadores.

No âmbito das práticas restaurativas ou das comissões da verdade, fazem parte a reconstrução da memória dos fatos, restauração e eventual reconciliação das relações rompidas, acolhimento e reintegração de ex-combatentes às sociedades das quais faziam parte. Ainda que se enxergue o desgaste da justiça penal para dar conta de todos os crimes praticados, ela é mobilizada para punir principalmente os mais altos escalões de comando do regime anterior, como ocorreu no Timor Leste.

c) Legitimações:

A perspectiva da legitimação atua nos casos nos quais a atuação das comissões pode fundamentar a renúncia à persecução penal. Parte-se do entendimento de que proliferam-se nos dias atuais teorias e práticas relacionadas à justiça restauradora ou reconstrutiva ("restorative justice" ou "reconstructive justice"), em oposição ao modelo retributivo de justiça penal. Conforme TAMARIT SUMALLA, sustenta-se que, sob certas condições, pode haver justiça para as vítimas sem castigo ao infrator, mas não é possível sustentar que haja justiça sem a reprovação ${ }^{334}$. Para o autor, ao censurar a conduta do infrator por meio de mecanismos legitimados e normativizados, e com capacidade de comunicação

${ }^{333}$ ZILLI, Marcos. "Punir or not punir? Qual é o verdadeiro dilema?", in Revista Anistia 9, p. 352 e ZILLI, Marcos. "A justiça de transição no Brasil: um caminho a percorrer". In: AMBOS, Kai; ZILLI, Marcos; ASSIS MOURA, Maria Thereza Rocha de; MONTECONRADO, Fabíola Girão. Anistia, justiça e impunidade. Reflexões sobre a justiça de transição no Brasil. Belo Horizonte: Fórum, 2010.

${ }^{334}$ Fazendo referência ao juízo de culpabilidade, cf. TAMARITT SUMALLA, VILLACAMPA ESTIARTE, Victimología, justicia penal y justicia reparadora, Ed. Ibáñez; Bogotá, 2006. 
eficaz dessa censura socialmente e em formato de possível compreensão ao infrator (longe, portanto, da sala fria da instituição de um tribunal), a vítima pode reequilibrar-se psiquicamente, superando seus sentimentos de vingança e de sofrimento, ao mesmo tempo que vê fortalecida sua participação social ${ }^{335}$

A prevalecer a construção retórica da reconciliação por meio do esquecimento, perpetuando-se a invisibilidade das vítimas, negamos o papel revelador da história e depurador do direito, invalidamos os preceitos de atribuição da justiça e mantemos a ignorância sobre o que o tempo já terá em breve apagado.

\subsubsection{Justiça de Transição e a Contenção da Perspectiva Punitivista}

O modelo de justiça promovido pelas comissões de verdade tende a considerar que a reparação pode representar uma forma de sub-rogação, ainda que parcial, da pena, especialmente em relação aos fins da pena consistentes na prevenção e reintegração social por meio da restauração das relações sociais. ROBINSON ${ }^{336}$ defende que há casos nos quais os trabalhos de uma comissão da verdade poderia representar uma alternativa à reponsabilidade penal internacional, com base nos arts. 17 e 53 do Estatuto do TPI, casos em que o procurador pode entender que houve investigação pelo Estado, ainda que não judicial, dentro da fórmula consagrada pelo Estatuto de que "tendo em consideração a gravidade do crime e os interesses das vítimas, não existirão ${ }^{337}$, contudo, razões substanciais para crer que o inquérito não serve os interesses da justiça.” Há, no entanto, posições divergentes com relação isso, inclusive durante as discussões para a aprovação do Estatuto,

\footnotetext{
${ }^{335}$ Em relação ao trabalho da Comissão Nacional da Verdade, no Brasil, seus membros afirmam a importância histórica da revelação de suas investigações: "mesmo que adequadamente consagrada, a verdade não promove o resgate da memória social se não é revelada e compartilhada. Essa constatação - a de que mais de $80 \%$ dos brasileiros nasceram após o golpe de 1964 e que 40\% (80 milhões) nasceram depois do final da ditadura, em 1985 - levou a CNV a dar especial atenção à efetivação do direito à memória, também uma de suas finalidades legais". DALLARI, Pedro, et. al. "Verdade, memória e reconciliação", Jornal Folha de S.Paulo, 10.12.2014, p. A3.

${ }^{336}$ ROBINSON, D. "Serving the interests of justice: Amnesties, Truth Commissions and the International Criminal Court”, European Journal of International Law, 2003, p. 493.

${ }^{337}$ Art. 53, 1.c, do ETPI. Infelizmente a tradução oficial do Estatuto do TPI no site do Planalto fornece uma tradução equivocada da versão original do dispositivo, conforme segue: "Taking into account the gravity of the crime and the interests of victims, there are nonetheless substantial reasons to believe that an investigation would not serve the interests of justice"'( grifo nosso). Nesse caso, a melhor tradução seria a que afirmasse que levando em consideração a gravidade do crime e os interesses da vida, houvesse razões substanciais (e não "não houvesse razões") para crer que o inquérito não serve os interesses da justiça.
} 
tendo-se optado por uma fórmula ambígua para a valoração caso a caso.

A redação do art. 17 estabelece que se o "caso for objeto de inquérito ou de procedimento criminal por parte de um Estado que tenha jurisdição sobre o mesmo", o TPI decidirá pela sua não admissibilidade. A doutrina debate se a expressão “inquérito" abrange apenas aqueles procedimentos policiais e de controle judiciário ou se abrangeria investigações voltadas ao descobrimento da verdade e levadas a cabo dentro de certas condições, como seu caráter "quase-judicial", independência do órgão, efetividade, necessidade, vocação de fazer justiça e não de oferecer impunidade, entre outros, consoante ROBINSON. HOLMES, no entanto, defende uma interpretação restritiva do dispositivo de somente referir-se a investigações criminais, matizada por $\operatorname{AMBOS}^{338}$, com base na proibição à impunidade para crimes de extrema gravidade, quando somente poderiam se admitir exceções em casos de "emergência nacional extrema". Ou seja, na dúvida entre uma interpretação mais ampla de admissibilidade do caso pelo TPI e outra mais restritiva, aplicarse-ia o princípio da máxima efetividade da proteção dos direitos humanos ${ }^{339}$, ainda que existentes mecanismos internos procurando discutir aspectos singulares do caso de acordo com os mecanismos de justiça de transição. Essa não nos parece ser a melhor solução, porque o país demonstraria que possui condições genuínas de investigar e processar o caso, ainda que em outros padrões. E o TPI não pode pretender que apenas o padrão ocidental de justiça seja o único entre as formas de as sociedades resolverem seus conflitos, nem que somente diante destes a jurisdição do TPI se afastaria para reconhecer a validade de um sistema de justiça não formal.

O outro lado da moeda, que afirma o direito ao castigo por parte das vítimas ou seus familiares é inspirado numa concepção neopunitivista, tendente a uma "punição infinita" ${ }^{340}$, configurando uma ameaça à concepção garantista do direito penal e em busca

\footnotetext{
${ }^{338}$ HOLMES, "The Principle of Complementarity". In: LEE, R.S. (ed.), The ICC: the making of the Rome Statute, 1999. AMBOS, K. Temas de derecho penal internacional y europeu, Madri: Marcial Pons, 2006, p. 30. A mesma posição restritiva é defendida por ONGs de direitos humanos, como a Human Rights Watch e a Anistia Internacional, com base na presunção favorável à investigação.

339 Adaptando-se o conceito de CANOTILHO, J.J., o princípio da máxima efetividade "é um princípio operativo em relação a todas e quaisquer normas constitucionais, e embora a sua origem esteja ligada à tese da atualidade das normas programáticas, é hoje sobretudo invocado no âmbito dos direitos fundamentais (no caso de dúvidas deve preferir-se a interpretação que reconheça maior eficácia aos direitos fundamentais)". Direito Constitucional e Teoria da Constituição, $6^{\mathrm{a}}$ edição, p. 227.

${ }^{340}$ PASTOR, D. El poder penal internacional. Una aproximación jurídica crítica a los fundamentos del Estatuto de Roma, Barcelona: Atelier, 2006, p. 75.
} 
da consolidação do que SILVA SÁNCHEZ chamou de princípio do "nullum crimen sine poena" ${ }^{341}$. Essa tendência levaria, ainda, a um modelo para o sistema penal que desnaturaria as garantias por meio de teorias como a imprescritibilidade ou a relativização do princípio do ne bis in idem. O cuidado, no fundo, que merecem essas ponderações é do uso exagerado do discurso punitivista diante dos crimes graves que desembocam no direito penal internacional e na proteção internacional dos direitos humanos, simultaneamente. A expansão, nesse sentido, deve contar com o freio constante que representa o direito penal mínimo, como critério que organiza o discurso penal, e ainda que se abra passo para punições exemplares pela justiça de transição ou pelas cortes penais internacionais, preservar o corpo jurídico da ciência penal para que a atribuição da pena não ocorra ao seu arrepio. Mas o fato é que algumas construções terão que ser reformuladas para que o escopo do direito penal internacional atinja seus objetivos, e uma delas é a de que o direito penal internacional não represente o avanço do discurso punitivista, mas a afirmação dos direitos humanos no plano internacional.

Embora a noção de punição domine o entendimento do que corresponde a justiça de transição ${ }^{342}$, remontando aos julgamentos simbólicos das Revoluções Inglesas e Francesas, dos Reis Carlos I e Luís XVI, o grande dilema é calibrar o espelho que olha para o passado, refletindo no futuro a imagem de uma sociedade sã. A manipulação das instituições do direito penal e processual penal são extremamente importantes para os regimes de exceção, como vemos com a suspensão das garantias do pedido de habeas corpus por meio do Ato Institucional n ${ }^{\circ} 5$ (AI-5) em casos de crimes políticos, ou como as alterações sofridas pela teoria do bem jurídico a partir da Escola de Kiel ${ }^{343}$. Essa manipulação é natural dentro de um regime que pretende se firmar, inclusive como garantidor e legitimador de suas instituições políticas e jurídicas. Por isso que a manipulação que o discurso de proteção dos direitos humanos deve ser cautelosa, criteriosa e valorosa das barreiras que lhes devem ser impostas, para não justificar um alto arbítrio em nome dos mais altos valores. E o arbítrio não deve ser cultivado pelo Estado de Direito nem para a máxima fortaleza dos direitos humanos, nem sua completa vulnerabilidade, mas consoante os critérios que se adotem para

\footnotetext{
${ }^{341}$ SILVA SÁNCHEZ, Jesús-María. "Nullum crimen sine poena? sobre las doctrinas penales de la "lucha contra la impunidad" y del "derecho de la víctima al castigo del autor", Universidad Externado de Colombia, 2008 , pp. 27 ss.

${ }^{342}$ TEITEL, Ruti, Transitional Justice, p. 27.

${ }^{343}$ FRAGOSO, Heleno Claudio. "Objeto do crime", Direito Penal e Direitos Humanos, Rio de Janeiro: Ed. Forense, 1977.
} 
a contenção do arbítrio. Assim, real e presente a frase de BECCARIA, de que "a crueldade dos tiranos é proporcional, não às suas forças, mas aos obstáculos que se lhes opõe"344.

É frequente que a nova ordem instaurada procure afirmar sua legitimidade e seu direito julgando os crimes da ordem política que a antecedeu. Os julgamentos dos Reis Carlos I e Luís XVI, assim como os julgamentos de Nuremberg, são referidos como atos políticos fundacionais, dizendo-se que "revolucionários devem se entender com o regime anterior: isso significa que eles devem encontrar algum processo ritualístico por meio do qual a ideologia que esses regimes defendem (...) possa ser publicamente repudiada" ${ }^{345}$. Com relação ao julgamento do Rei Luís XVI, afirma-se que o "regicídio público é uma forma absolutamente decisiva de romper com os mitos do antigo regime, e é por essa única razão, o ato fundacional do novo", nesse caso, de que o rei não estava acima da lei. Por outro lado, as investigações levadas a cabo pelo novo regime tendem a controlar o curso das investigações, justamente para jogar luz sobre fatos de interesse do passado político do país ${ }^{346}$.

O dilema dos processos de transição tem como traço comum a atribuição de responsabilidade individual pelos ilícitos sistematicamente perpetrados sob um regime repressivo. Entretanto, o resultado do processo investigativo e das audiências públicas propõe uma reflexão sobre o papel dos objetivos retributivos, que não necessariamente atribuem a culpabilidade ou determinam penas. Ao contrário, pela reconstrução dos fatos, fortalece-se a memória histórica e os discursos revelados, ao mesmo tempo que estigmatizase o fato mais do que as pessoas, a ação coletiva como fato reprovável, pelo contexto político e forma sistemática de perpetração. Conforme RICOUER ${ }^{347}$, deixa-se conduzir pela ideia da reconstrução do sentido simbólico buscado pelas sociedades que recorrem à justiça de transição, pois que seu reverso, a fragmentação, seria a dispersão da memória e, nisso, o sentimento de culpa.

Notamos que muitas vezes recorre-se às instâncias internacionais pelo fato de não se encontrar no direito nacional a forma de ter as demandas pelas violações graves

\footnotetext{
${ }^{344}$ BECCARIA, Cesare. Dos Delitos e das Penas. Cap. IV, sobre a interpretação das leis.

${ }^{345}$ WALZER, Michael. Regicide and Revolution, p. 88 (trad. livre).

346 TEITEL, Ruti G. Transitional Justice, op. cit., p. 50 (trad. livre).

${ }^{347}$ RICOEUR, Paul. La mémoire, l’histoire, l'oubli. Paris: Édititions du Seuil, 2000, pp. 598-599.
} 
acolhida. Há casos nos quais os julgamentos dos responsáveis por violações são difíceis de serem julgados dentro da perspectiva do modelo de justiça comum ${ }^{348}$. A intensidade com que o recurso às instâncias internacionais tem ocorrido, a criação de diversas instâncias com esse objetivo no plano regional ou internacional e, especialmente, o diálogo que se estabelece entre a esfera nacional e internacional, na expressão de CARVALHO ${ }^{349}$, "diálogo entre as cortes", marca o impulso a essa área jurídica do direito penal internacional.

\subsection{O sistema latino-americano de proteção de direitos humanos e o direito penal internacional}

Uma análise jurisprudencial das decisões dos tribunais locais de casos envolvendo fatos que poderiam ser caracterizados como crimes internacionais acabavam sendo julgados segundo o direito local ${ }^{350}$. Essa primeira análise levou em conta decisões até 2003, tendo o cenário mudado para uma nova dinâmica de recorrência ao direito internacional penal, inclusive para ultrapassar as dificuldades do sistema local.

Observa AMBOS e MALARINO ${ }^{351}$ que na Argentina, os primeiros casos a fazerem referência a conceitos de direito penal internacional foram casos de extradição, como do médico alemão Bohne, que participava de uma organização acusada de eliminar doentes mentais com o uso de câmaras de gás, além dos casos Schwammberger e Priebke, com decisões de 1966, 1989 e 1995. A Corte Suprema argentina considerou que as condutas violariam "al común sentir de los pueblos civilizados", correspondendo a ações "lesivas del

\footnotetext{
348 Por exemplo nos casos de julgamentos de tortura na Grécia, analisado pela Anistia Internacional, Torture in Greece: the first torture's trial, 1975, Londres, 1977, ou dos julgamentos ocorridos na Indonésia pelas violações cometidas no Timor Leste após sua independência.

${ }^{349}$ Ramos, André de Carvalho. "Pluralidade das ordens jurídicas: uma nova perspectiva na relação entre o Direito Internacional e o Direito Constitucional”, Revista da Faculdade de Direito da USP. v. 106-107, jan/dez 2011/2012, pp. 514 ss. O autor aborda o tema da harmonização dos diversos planos jurídicos, em especial da juridificação das relações internacionais, "fenômeno que consiste na formatação jurídica das relações internacionais outrora dominadas pelas injunções de força" e da constitucionalização do direito internacional. Afirma o autor que a "constitucionalização do Direito Internacional consiste em um fenômeno pelo qual o Direito Internacional mimetiza institutos outrora reservados ao Direito Constitucional, como, v.g., criação de tribunais, proteção de direitos fundamentais, rule of law, acesso direto de indivíduos, julgamento de indivíduos no campo penal (até com pena de caráter perpétuo), entre outros” (p. 502). Assim, além da realização dos direitos fundamentais, o direito internacional nesta nova configuração também exerce sua vocação organizando poderes, instituições e competências.

350 AMBOS e MALARINO, "Persecución penal nacional de crímenes internacionales en América Latina. Conclusiones". In: AMBOS e MALARINO (org.): Persecución penal nacional de crímenes internacionales en América Latina y España, Montevidéu: Fundación Konrad Adenauer, 2003, p. 584.

${ }^{351}$ AMBOS e MALARINO, Persecución penal nacional de crímenes internacionales, op. cit., 2003, p. 422 ss.
} 
sentimiento de humanidad", afastando que estariam revestidas de caráter político, uma vez que "el derecho de las gentes ha ido progresivamente negando un trato favorable (...) a aquellas acciones que (...) revisten el carácter de crímenes graves". No segundo caso, consideram crimes contra a humanidade, imprescritíveis, conforme o direito internacional, apesar de não existir referida previsão no direito interno. Apesar de se tratar de uma imprescritibilidade ex post facto, a Corte justificou que no âmbito internacional inexiste separação de poder e, portanto, violação do princípio da legalidade. O último caso foi julgado como crime de guerra e genocídio, afirmando sua imprescritibilidade nos termos do princípio do ius cogens vigente no direito internacional ${ }^{352}$.

A partir de 2004, no caso contra Arancibia Clave, acusada de integrar uma associação criminosa chilena (DINA), a decisão de lhe atribuir responsabilidade é permeada por conceitos de direito penal internacional. Ainda que fundamentada no código penal argentino, considerou-se que quando uma associação está dedicada a cometer crimes de lesa humanidade, seu crime associativo se converte à própria categoria de cometimento do crime e, como tal, imprescritível. Esta norma, observou a Corte, faz parte do costume internacional, fonte de direito internacional e não violadora do princípio da legalidade.

Igualmente, no caso Simón, inspirada pela decisão da CIDH no caso Barrios Altos, a Corte Suprema julgou em 2005 reafirmando a imprescritibilidade dos fatos discutidos e desconsiderou os efeitos da causa julgada, qualificando os atos levados ao processo de provação ilegítima de liberdade, e crime de lesa humanidade. Para ZAFFARONI e PETRACCHI, no voto conjunto no processo de extradição Astiz ${ }^{353}$, afirmando-se que:

"a suposta falta de certeza quanto às possibilidades reais de julgamento de
Astiz no país que alegam os recorrentes, sobre a base de que até o momento
o Tribunal não tenha expedido com relação à constitucionalidade da lei n.
25.779 , que declara insanavelmente nulas as leis 23.492 ("ponto final") e
23.521 ("obediência devida"), perde de vista, a partir do caso Barrios Altos
da Corte Interamericana de Direitos Humanos (sentença de 14 de março de
2001), resultam contrários à Convenção Americana de Direitos Humanos
todas aquelas normas com as características das mencionadas leis 23.492

${ }^{352}$ Importante esclarecer que estas discussões não faziam parte do processo de apuração da responsabilidade criminal, mas em sede de extradição.

353 Alfredo Ignacio Astiz foi um dos militares argentinos incluídos no mega-processo de revisão dos fatos ocorridos durante a ditadura militar argentina, acusado de matar duas freiras francesas, condenado à revelia na França à prisão perpétua (trad. livre do voto). 
e 23.521, visto que elas impedem a investigação e condenação de fatos como os que motivaram o atual pedido da República Francesa".

No caso Derecho, a Corte aborda o tema do bem jurídico e o elemento de contexto do crime de lesa humanidade, raciocinando que o crime protege a humanidade em seu conjunto e secundariamente as pessoas afetadas pelas condutas individuais. E o que distingue um crime comum de outro de lesa humanidade não é sua crueldade ou depravação inerentes àquela conduta, mas o fato de "que ésta sea ejecutada por un Estado o una organización cuasigubernamental en contra de las personas que están bajo su control y que deben proteger" ${ }^{354}$.

Fato é que, apesar do reconhecimento da relevância especial do crime considerado como de lesa humanidade, poucas referências são encontradas em relação aos requisitos de contexto, isso é, “de aquellas condiciones que precisamente transforman un crimen común en un crímen internacional" ${ }^{355}$. Cabe referir à tendência anotada por AMBOS e MALARINO de ampliar o conceito de crimes contra a humanidade para além da definição internacional, abrangendo também associação ilícita (caso Arancibia Clavel), subtração e ocultação de menor (caso Videla), falsificação ideológica de documento público (caso Pazo), roubo de bens, associação ilícita e roubo (caso García Velasco), ocultação e subratação de documentos que indicavam o paradeiro ou situação de pessoas desaparecidas (caso Navarro).

Na Colômbia, a respeito da compatibilidade entre o Estatuto do TPI e o direito interno, entendeu-se que poderiam ser concedidas anistias ou indultos sempre que as vítimas pudessem ter acesso à justiça para conhecer a verdade e obter uma proteção judicial efetiva de seu direito, embora não reconheça a validade das auto-anistias, anistias em branco ou leis de ponto final ${ }^{356}$.

Com relação à imprescritibilidade de crimes internacionais, nos termos do art. 7 da Convenção Interamericana sobre o Desaparecimento Forçado de Pessoas (CIDFP), no contexto colombiano, decidiu-se pela sua compatibilidade com o art. 28 da Constituição, que

\footnotetext{
${ }^{354}$ AMBOS e MALARINO, "Persecución penal nacional de crímenes internacionales, op. cit., 2003, p. 425. ${ }^{355}$ Idem, p. 425.

${ }^{356}$ Trata-se da sentença C-578/02, de 2002, mas também encontrada na sentença T-249/03, de 2003, da Corte Constitucional da Colômbia.
} 
prevê a inexistência de penas imprescritíveis. Entendeu-se que não se tratava de uma garantia absoluta, sobretudo diante da gravidade dos casos de desaparecimento forçado de pessoas e da não prevalência da impunidade e o direito à justiça ${ }^{357}$.

Outra reviravolta promovida pela integração do direito penal internacional ao direito nacional decorre da revisão do art. 220(3) do Código de Processo Penal, que previa que nos casos de descoberta de novas provas ou fatos, poder-se-ia requerer a revisão da sentença somente quando fosse condenatória, também tratando do princípio do ne bis in idem. A Corte inovou com o entendimento de que quando se tratar de graves violações abrangidas pelo direito internacional penal, humanitário, levando à situação de impunidade, colocaria em risco a "ordem justa" 358 . Entendeu-se que a manutenção do entendimento expresso pelo CPP indicaria uma gravidade maior, pois a impunidade derivaria do descumprimento pelo Estado "del deber de investigar y sancionar adequadamente estos crímenes y especialmente cuando ello se traduce en una vulneración de los compromisos internacionales asumidos por el Estado"359.

O caso peruano é especialmente rico por confrontar as leis nacionais com a primeira decisão jurisprudencial que categoricamente afirmou os preceitos que valeriam para os demais casos enfrentados pela CIDH. Além da decisão de fundo do caso Barrios Altos, de 14 de março de 2001, em setembro do mesmo ano, a CIDH expediu uma decisão interpretativa da primeira decisão, à que deu efeitos gerais. Para o caso Barrios Altos, consideraram-se inadmissíveis as leis de anistia, as disposições sobre prescrição e a definição de excludentes de responsabilidade para impedir a investigação e punição dos responsáveis pelas graves violações aos direitos humanos. Levada a questão ao Tribunal Constitucional peruano, confrontando-se com as leis internas vigentes, o Tribunal rechaçou as alegações de violação do princípio do ne bis in idem, sustentando que o direito busca impedir que o Estado persiga arbitrariamente uma pessoa por mais de uma vez, e isso não ocorria quando um novo processo existe em decorrência da nulidade do primeiro.

\footnotetext{
${ }^{357}$ V. MARTIN-CHENUT, Kathia “A valorização das obrigações positivas de natureza penal na jurisprudência da CorteIDH: o exemplo das graves violações de direitos humanos cometidas durante as ditaduras dos países do Cone-Sul", in RBCCRIM, n 102, São Paulo: Ed. RT, 2013.

358 Sentença 004/03 de 2003, da Corte Constitucional da Colômbia, também com apoio no art. 20(3) do ECPI, permitindo deixar de lado a coisa julgada em prejuízo do indivíduo processado absolvido.

${ }^{359}$ AMBOS e MALARINO, "Persecución penal nacional de crímenes internacionales", op. cit., 2003, p. 429.
} 
O repertório de jurisprudência latino-americana indica diversos casos de aplicação do direito penal internacional no Peru, principalmente envolvendo o reconhecimento do direito à verdade, de estatura constitucional, albergado pelo princípio da dignidade humana, que diz não apenas como direito a ter acesso a documentos oficiais, como também e principalmente o direito a uma investigação dos fatos, inclusive como parte da reparação moral da vítima. Mais uma vez se indica que esse tipo de decisão se justifica pelos “intereses prevalentes de la lucha contra la impunidad"360. Em outro caso citado, o Tribunal Constitucional qualificou os desparecimentos forçados praticados no casos conhecidos como La Cantuta e Barrios Altos como crime permanente e pluriofensivo que, praticado de forma sistemática ou generalizada, se converte em um crime de lesa humanidade, cuja gravidade "fundamenta una especial necesidad social de esclarecimiento".

Com relação à jurisprudência do Chile, faz-se referência ao caso Sandoval Rodrigues (acusados, Krassnoff e outros), retomando-se o entendimento em relação à aplicação dos Convênios de Genebra para crimes de guerra (1949), quando se vedavam " $e l$ disponer de medidas que tenderian a amparar los agravios cometidos (...) o lograr la

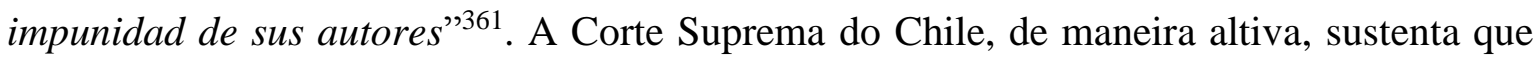
"la soberanía interna del Estado de Chile reconoce su límite en los derechos que emanan de la naturaleza humana; valores que son superiores a toda norma que puedan disponer las autoridades del Estado, incluyendo el propio Poder Constituyente".

Por fim, no caso Rioseco Montoya e Cotal Álvares ${ }^{362}$, a Corte Suprema do Chile negou a qualificação de crimes contra a humanidade ou crimes de guerra e, assim, inaplicáveis as consequências do direito internacional, sustentando-se que a Convenção sobre a Imprescritibilidade de Crimes de Guerra e Lesa Humanidade (CICGLH) e o Estatuto do TPI não eram instrumentos vigentes à época dos fatos discutidos.

Posteriormente este entendimento foi revisto no julgamento do caso Vázquez Martínez e Superby Jeldres, no qual o assassinato de opositores ao regime foi considerado crime de lesa humanidade e declarada sua imprescritibilidade. Desta feita, a Corte considerou que os crimes já eram punidos com base no delito de homicídio e que a regra da

\footnotetext{
${ }^{360}$ V. caso Villegas Namuch, decisão de 18 de março de 2004 do Tribunal Constitucional peruano.

${ }^{361}$ Caso Poblete Córdova, sentença de 9 de setembro de 1998.

${ }^{362}$ Sentença de 5 de agosto de 2005.
} 
imprescritibilidade já se encontrava vigente por formar parte do direito consuetudinário, anteriormente à incorporação da CICGLH.

Consoante adverte MALARINO, em decorrência da aplicação de critérios elaborados pela CIDH, os tribunais de países latinoamericanos, ao darem cada vez mais amplitude a estes critérios, estão criando um direito penal diferenciado para violações dos direitos humanos, ou seja, um direito penal que corre por trilhos diferentes ao direito penal comum, e caracterizado sobretudo pela restrição dos direitos do acusado e, paralelamente, ao aumento dos direitos da vítima. Segundo MALARINO, neste novo direito penal ${ }^{363}$ :

- "Nao existe prescrição;

- Não são admissíveis as disposições que prevêem a anistia, indultos ou outras isenções similares à responsabilidade penal;

- Não opera a coisa julgada (ne bis in idem), seja para possibilitar o renascimento de uma ação prescrita por uma lei de anistia, indulto, etc., seja para reabrir um processo finalizado com sentença absolutória pelo descobrimento de novos fatos ou provas após a sentença;

- Não vale o princípio da legalidade ou, quando assim previsto, este princípio é reconhecido de uma maneira tão fraca que para sua satisfação basta uma norma consuetudinária prévia ao fato (nullum crimen sine iure) - esta é a posição majoritária - ou ainda um delito no ordenamento interno que abarque a substância - e apenas isso - de uma infração de crime internacional que dito ordenamento não contém (por exemplo, o tipo do homicídio serviria para satisfazer a legalidade do crime contra a humanidade, ou bem, finalmente, para aqueles que optam pelo caminho da sinceridade - que são a minoria - defende uma aplicação retroativa da lei penal justificada pela gravidade dos fatos."

Outra forma de ver a questão, buscando de maneira simples um padrão de generalidade a entender esses julgamentos, é a de que os processos contra os ex-líderes políticos em processos de transição foram poucos, visto terem sido seletivamente escolhidos,

\footnotetext{
${ }^{363}$ MALARINO, op. cit., p. 443 ss.: "no existe la prescripción; no son admisibles las disposiciones de amnistías, indultos y otras exenciones similares de la responsabilidad penal; no opera la cosa juzgada (ne bis in idem), sea para posibilitar el renacimiento de una acción fenecida por una ley de amnistía, indulto, etcétera, sea para reabrir un proceso finalizado con sentencia absolutoria por el descubrimiento de nuevos hechos o nuevas pruebas luego de la sentencia; no rige el principio de legalidad o, cuando sí lo hace, este principio es concebido de una manera tan débil que para su satisfacción basta una norma consuetudinaria previa al hecho (nullum crimen sine iure) - esta es la posición mayoritaria -, o bien un delito en el ordenamiento interno que abarque la sustancia -y sólo eso- de la infracción del crimen internacional que dicho ordenamiento no contiene (por ejemplo, el tipo de homicidio serviría para satisfacer la legalidad del crimen de lesa humanidad), o bien, finalmente, quienes optan por el camino de la sinceridad —que son los menos-defienden una aplicación retroactiva de la ley penal justificada en la gravedad de los hechos".
} 
as condenações ocorreram de forma variada e as anistias utilizadas largamente. Os princípios legais têm sido vigorosamente contestados, sendo o principal foco justamente a crítica de até onde esses julgamentos seriam apenas instrumentos políticos visando adversários políticos com base em uma lei que não estava em vigor no tempo em que os atos foram cometidos ${ }^{364}$. Estamos, portanto, muito próximos dos elementos apresentados no capítulo $1^{\circ}$ que identifica o fenômeno da expansão do direito penal, neste momento, pelas instâncias mais autorizadas de realizar, na prática, os valores da proteção dos direitos humanos.

O tema da prescrição é igualmente rico de debate, em vista do afastamento de sua incidência diante dos crimes de direito internacional. Entretanto, a maioria dos instrumentos jurídicos sobre crimes de direito internacional não faz referência à prescrição, como o Estatuto do Tribunal Militar de Nuremberg e o de Tóquio, assim como na Convenção para a Prevenção e a Repressão ao Crime de Genocídio, de 1948, e nos princípios de Nuremberg adotados pela CDI, de 1950. Vinte anos após a convenção sobre o crime de genocídio e dos crimes perpetrados na II Guerra Mundial, e quando estes estivessem próximos de prescreverem, a Assembleia Geral das Nações Unidas adotou a Convenção sobre a Imprescritibilidade dos Crimes de Guerra e dos Crimes contra a Humanidade, em 1968, estabelecendo que não prescrevem nem as ações com relação aos crimes internacionais mencionados nem as penas (art. $4^{\circ}$ ). Esta Convenção não foi ratificada largamente pelos países, talvez pelo fato de ela prever sua aplicabilidade inclusive para o período anterior à sua entrada em vigor $\left(\operatorname{art.} 1^{\circ}\right)$.

A Convenção Europeia sobre a Imprescritibilidade dos Crimes de Guerra e dos Crimes contra a Humanidade, de 1974, não contou com adesão significativa, tendo sido ratificada apenas pela Holanda e Romênia. Na mesma década, os Protocolos Adicionais às Convenções de Genebra nada falam do tema, cujo silêncio também é repetido na Convenção contra a Tortura, de 1984. O Projeto de Código dos Crimes contra a Paz e a Segurança da Humanidade adotado pela CDI em 1996, os Estatutos dos TPI para Iugoslávia e Ruanda tampouco falam, ainda que os tribunais tenham reconhecido a imprescritibilidade em suas decisões. A Convenção Interamericana contra os Desaparecimentos Forçados prevê a imprescritibilidade em seu art. $7^{\mathrm{o} 365}$.

${ }^{364}$ KOSKENNIEMI, Martii. "Between impunity and show trials". Max Planck UNYB, 6, 2002.

365 Convenção Interamericana contra os Desaparecimentos Forçados, art. $7^{\circ}$ "A ação penal decorrente do desaparecimento forçado de pessoas e a pena que for imposta judicialmente ao responsável por ela não estarão 
A questão foi melhor enquadrada no Estatuto de Roma, ao prever no art. 29, entre os princípios do direito penal, a imprescritibilidade dos crimes sujeitos à jurisdição do TPI. Essa norma, lida em conjunto com o art. 11, que prevê que a competência do TPI será exercida somente após a entrada em vigor do Estatuto, indica que a imprescritibilidade também deve ser considerada somente a partir da entrada em vigor do Estatuto. Não obstante, há o entendimento defendido por alguns de que a imprescritibilidade dos crimes internacionais se baseia no direito costumeiro e já vem sendo aplicado pelos países, como no pedido de extradição feito pela Espanha de Ricardo Miguel Cavallo, nacional argentino, ao México. O pedido de extradição tinha por objeto a acusação de crimes de tortura, genocídio e terrorismo. Ocorre que pela legislação mexicana o crime de tortura já havia prescrito, mas o Min. das Relações Exteriores entendeu que a tortura seria um crime imprescritível diante das convenções firmadas internacionalmente por seu país ${ }^{366}$.

sujeitas a prescrição. No entanto, quando existir uma norma de caráter fundamental que impeça a aplicação do estipulado no parágrafo anterior, o prazo da prescrição deverá ser igual ao do delito mais grave na legislação interna do respectivo Estado Parte."

${ }^{366}$ Resolução da Secretaria de Relações Exteriores - Direção Geral de Assuntos Jurídicos, procedimento de extradição contra o nacional argentino Ricardo Miguel Cavallo, p. 58-9. 


\section{CAPÍTULO 3 - DIREITO PENAL INTERNACIONAL - ELEMENTOS}

Nos capítulos anteriores, procuramos apresentar as condições de afirmação e o processo de construção do direito penal internacional como elemento que leva à expansão do direito penal para além de seus domínios tradicionais. Nas próximas seções, avançaremos sobre os elementos estruturais que singularizam o direito penal internacional em suas categorias próprias, tratando, portanto do que são considerados crimes internacionais para o direito penal internacional, dos contornos sobre o ius cogens e, finalmente, do expansionismo por trás da flexibilização do princípio da legalidade por meio do recurso à fonte costumeira, à jurisdição universal e à teoria do bem jurídico.

\subsection{Crimes Internacionais vs. Crimes de Direito Internacional}

\subsubsection{Aspectos Gerais e Definição}

Ao lado do movimento relacionado à instauração dos tribunais penais internacionais, também faz parte do direito penal internacional a tipificação internacional de delitos e sua forma de repressão, por meio das fontes próprias de direito internacional, visando a proteção penal da comunidade internacional e dos bens jurídicos supranacionais ou supraindividuais, por meio da repressão aos crimes internacionais próprios ou crimes de direito internacional. Desta forma, de maneira simplificada, inclui-se na disciplina o que for do interesse da comunidade internacional ${ }^{367}$ e exclui-se o que é da esfera interna do Estado, ainda que relacionado à persecução penal e à atuação internacional do Estado $^{368}$. Retomando

\footnotetext{
${ }^{367}$ Faz-se referência, a respeito do interesse da comunidade, à presença de um "elemento internacional", buscando proteger os mais relevantes bens jurídicos da comunidade internacional dos ataques que ocorrem num contexto sistemático ou massivo de violência, cuja responsabilidade por estes ataques recai, em geral, sobre um ente coletivo, o Estado (embora o próprio art. 25.4 do Estatuto do TPI estabeleça que a responsabilidade do Estado é independente da das pessoas naturais). O fato global de violência organizada ( "Gesamttat") é o que diferencia dos crimes individuais, referido em relação aos crimes de genocídio e contra a humanidade, por exemplo. V. WERLE, Gerhard. Tratado de DPI. Op. cit., pp. 81-83.

${ }^{368}$ Nossa definição de direito penal internacional nos separa de grandes estudiosos, como BASSIOUNI e, entre nós, JAPIASSÚ, para quem o direito penal internacional abrangeria também regras relativas à aplicação
} 
o conceito apresentado no início do segundo capítulo, entendemos o direito penal internacional como a área do direito que estuda a aplicação das disposições com conteúdo penal emanadas da comunidade internacional com o fim de tutelar seus interesses fundamentais, às quais estariam submetidos diretamente os cidadãos de todas as nações e que seriam aplicadas por órgãos internacionais ou nacionais cujo ordenamento admitisse a aplicação direta dos tipos penais baseados no direito penal internacional. Assim, conforme WERLE, o direito penal internacional compreende todas as normas que fundamentam uma punibilidade de forma direta no direito internacional ${ }^{369}$. Uma outra definição, trazida por AMBOS, é a de que o direito penal internacional é o conjunto de todas as normas de direito internacional que estabelecem consequências jurídico-penais, combinando "princípios de direito penal e de direito internacional" 370 , ou, em outras palavras, "o sistema penal da comunidade internacional”. Para CASSESE, é o corpo jurídico criado para proibir certas categorias de condutas e para tornar aquelas pessoas que as praticam criminalmente responsáveis. Eles consequentemente ou autorizam Estados, ou impõem sobre eles obrigações para processar e punir estas condutas ${ }^{371}$.

A origem do direito penal internacional também encontra-se ligada ao processo de afirmação dos direitos humanos, tendo por raiz comum o direito internacional humanitário. Segundo WERLE, os direitos humanos são fonte de direitos individuais e o direito penal internacional a fonte de responsabilidade penal na órbita internacional, tendo essa relação se estreitado profundamente após os eventos catastróficos da II Guerra Mundial. Como duas caras da mesma moeda, sustenta WERLE que cada pessoa natural seja destinatária de direitos (humanos) e deveres (responder diante de omissões ou ações penalmente tipificadas) internacionais. Os direitos humanos objeto de proteção penal internacional são somente aqueles mais violentamente atacados, representando a

extraterritorial do direito penal interno, como a extradição, que, ligados à internacionalização do crime e de sua repressão, não o destacam para essa nova dogmática rumo a um direito supranacional. V. BASSIOUNI, M. Cherif. International Criminal Law. Project for an International Criminal Code.; JAPIASSÚ, Carlos Eduardo Adriano. O Direito Penal Internacional. Belo Horizonte, Ed. Del Rey, 2009, pp. 4-5.

369 WERLE, Gerhard. Tratado de Derecho Penal Internacional, op. cit., p. 76. WERLE afirma que essa definição encontra apoio majoritário da doutrina alemã, condensada na expressão Völkerstrafrecht (direito penal internacional), empregada pela primeira vez por BELING, Die strafrechtliche Bedeutung der Exterritorialität, 1896, pp. 40 ss.

${ }^{370}$ AMBOS, Kai. A parte geral do direito penal internacional: bases para uma elaboração dogmática (Trad. Carlos Eduardo Adriano Japiassú e Daniel Andrés Raizman). São Paulo: Ed. Revista dos Tribunais, 2008, p. 42.

${ }^{371}$ CASSESE, Antonio. International Criminal Law, Oxford: Oxford Univ. Press, $2^{\text {a }}$. ed., 2008, p. 3. 
criminalização internacional o mais alto nível de proteção, aplicando-se com vigor o princípio de que o direito penal atua como mecanismo de ultima ratio.

O direito penal internacional passa a fazer sentido e a ganhar concreção quando os atores jurídicos internacionais no âmbito do direito público não são mais restritos apenas aos Estados-Nação. O sistema prevalente de um direito internacional público criado e controlado por Estados soberanos, para sua conveniência, valorosos de suas doutrinas clássicas de imunidade diplomática e soberania, não intervenção em assuntos domésticos, não submissão compulsória à Corte Internacional de Justiça, igualdade de votos dos Estados na Assembleia Geral, prejudicam os direitos humanos ${ }^{372}$.

O sistema de justiça criminal proposto por BASSIOUNI seria uma combinação de instituições internacionais, como o TPI, os tribunais ad hoc, escritórios de investigação, sistemas nacionais de justiça criminal que atuem de forma complementar ${ }^{373}$ para a aplicação das normas de direito penal internacional. Diante do horror que afeta a consciência mundial, resulta um regime jurídico próprio, cujas características, no entender de ZILLI, ASSIS MOURA e MONTECORNADO ${ }^{374}$, abrangem a consagração do direito costumeiro, da imprescritibilidade, da impossibilidade de anistia e da imprestabilidade da coisa julgada fraudulenta. DELMAS-MARTY ${ }^{375}$ agrega, ainda, elementos estruturais para a confirmação de uma gramática comum. A primeira é a da legitimidade/efetividade, combinando a relação de legitimidade, em referência axiológica à proteção e exaltação dos mesmos valores: uma construção que seja equilibrada entre os critérios em torno dos quais gravita essa comunidade de Estados, as circunstâncias relativas aos acusados, aos interesses das vítimas, em relação

\footnotetext{
${ }^{372}$ Nas palavras do autor, "at the beginning of the twenty-first century, international law remains subordinate and subservient to state power, which tends to favor economic, political or military interests whenever they conflict with those of justice. That said, realpolitiking these days must take human rights into account, if only because CNN viewers cast votes and NGOs in the area attract considerable funding and popular appeal". ROBERTSON, Geoffrey. Crimes Against Humanity - The Struggle for Global Justice, Alan Lane: Penguin, 1999, pp. 91 e 92.

${ }^{373}$ BASSIOUNI, M. Cherif. "International Criminal Justice in the Age of Globalization", International Criminal Law: Quo Vadis?, op. cit., pp. 79-81.

374 ZILLI, Marcos; ASSIS MOURA, Maria Thereza; MONTECONRADO, Fabíola Girão. "A Justiça de Transição no Brasil - um caminho ainda a percorrer". In: AMBOS, Kai; ZILLI, Marcos; ASSIS MOURA, Maria Thereza; MONTECONRADO, Fabíola Girão. Anistia, Justiça e Impunidade - reflexões sobre a Justiça de Transição no Brasil. Belo Horizonte: Ed. Fórum, 2010, pp. 186-187. AGUILAR, Francisco. Amnistia e constituição. Coimbra: Almedina, 2004, p. 186.

${ }^{375}$ DELMAS-MARTY, Mireille. "La CPI et les interactiones entre droit internacional pénal et droit pénal interne à la phase d'ouveture du procès pénal". Revue de Science Criminelle et de Droit Pénal Comparé, 3 , jul/set, 2005, p. 480.
} 
à efetividade, que remete à possibilidade de sucesso das investigações e de julgamentos e da credibilidade do Tribunal. A segunda gira em torno de um eixo formado pelo universalismo/relativismo, buscando a conjugação do universalismo de uma justiça penal com vocação mundial, baseada na gravidade dos crimes contra o direito internacional, invocando valores de base universal, com o relativismo das situações nacionais, devendo-se levar em conta de modo diferenciado alguns critérios, como o interesse das vítimas, o impacto dos processos na situação de cada país ou o recurso, em alguns casos, às formas alternativas de resolução de conflito. Cabe-nos refletir sobre o conjunto, que não deve ser uma ordenação da soma das várias partes, mas da construção de uma nova unidade, em torno de valores e funcionalidades, que corresponda e atente para a ordenação plural dos sistemas que compõem ou inspiram a justiça criminal internacional.

Numa perspectiva formal, encontramos a construção proposta por WERLE, que formula que para uma norma fazer parte do corpo jurídico penal internacional, ela deve preencher três condições: a norma deve descrever um injusto imputável individualmente e ameaçar com uma sanção penal ${ }^{376}$; a norma deve ser parte do ordenamento jurídico internacional; e, por fim, a punibilidade deve existir com independência à recepção do tipo delitivo na ordem jurídico estatal.

Em relação a esses critérios, para o direito internacional clássico, não havia o indivíduo como ator das disputas que sob ele se produziam. Assim, era inimaginável que uma norma de direito internacional pudesse ser infringida por pessoas individuais. Há delitos do indivíduo, mas não delitos contra o direito internacional, conforme cita JESCHECK ${ }^{377}$. Afirma o autor que somente o direito estatal poderia proteger com suas próprias normas o direito internacional, resvalando ao final no indivíduo sua responsabilidade jurídico-penal

\footnotetext{
${ }^{376}$ Isto porque já se declarou a importância do princípio da culpabilidade em direito penal internacional: "well settled legal principles, one of the more importante of which is that criminal guilt is personal, and that mass punishments should be avoided" ("bem estabelecidos os princípios legais, dos quais um dos mais importantes é o de que a culpa criminal é pessoal, e o de que as punições massivas devem ser evitadas" - trad. livre), Tribunal Militar Internacional, sentença de $1^{\circ}$ de outubro de 1946. A necessária vinculação da pena à culpabilidade do autor é um dos princípios centrais do direito penal, a indicar a possibilidade de existência de sanção ("se" existe pena), mas também sua extensão. A esse respeito, entre outros, FRISCH, Wolfgang, "Sobre el futuro del derecho penal de la culpabilidade” (Trad. Bernardo J. Freijoo Sánchez). In: FREIJOO SÁNCHEZ, Bernardo José (ed.). Derecho Penal de la Culpabilidad y Neurociencias, Civitas, Madri, 2012. Também BASSIOUNI, M. Cherif. Crimes against humanity, 1992 e Crimes against humanity in international law, 1999 e LEBEN, Charles. "The changing structure of international law revisited. By way of introduction". EJIL, 1997, p. 399-409.

377 JESCHECK, H.H. "Nuremberg Trials". In: BERNHARD, R. (ed). Encyclopedia of Public International Law, Inst. 4, 1982, p. 542, citado por GIL GIL, op. cit., 1999, p. 5.
} 
em relação às obrigações impostas ao Estado - ou seja, a relação do indivíduo com a comunidade internacional era indireta, intermediada pelo Estado. Apenas recentemente passou-se a considerar, em casos específicos, o indivíduo como sujeito passivo e ativo das obrigações na ordem internacional, notadamente diante de graves violações de normas protetivas da existência e integridade de uma comunidade ${ }^{378}$. Seguindo os passos do Tribunal de Nuremberg e de Tóquio, e posteriormente os tribunais ad hoc para a Iugoslávia e Ruanda, transformou-se a natureza da responsabilidade criminal, originalmente atribuída aos Estados, para uma responsabilidade centrada no indivíduo, afirmando-se que o direito resultante das decisões dos tribunais internacionais humanizaram o próprio direito humanitário sob dois aspectos principais: por meio da interpretação que leva à busca da realização dos objetivos da norma (perspectiva propositiva); pela prioridade dada à nova forma de se compreender a cláusula Martens ${ }^{379}$, do direito dos conflitos armados e a proteção da população civil no âmbito do direito internacional (perspectiva protetiva).

O direito penal internacional tem como destinatário as pessoas naturais, e não o Estado, promovendo, pela renovação própria do direito, a atualização do direito internacional, que passa a não apenas considerar o indivíduo como sujeito de direitos na esfera internacional, mas especialmente a receber as influências domésticas à hora de formular teorias jurídicas, construir os princípios, respaldar suas decisões, avaliar elementos políticos na definição dos processos de justiça de transição. Embora de forma diferente, o direito internacional se fez especialmente perene ao direito nacional primeiro, na conformação da proteção internacional dos direitos humanos, e segundo, na interação propiciada e demandada pela construção do direito penal internacional.

As características desta nova área são, no entender de $\operatorname{CASSESE}^{380}$ : a) uma formação ainda em progresso, ainda não concluída do conjunto de regras geralmente aplicáveis; b) fundada em regras baseadas no direito consuetudinário, com novas classes de crimes e elementos constitutivos vigentes ainda que naquela época ainda não totalmente

\footnotetext{
${ }^{378}$ Sobretudo a partir da decisão do TMI de Nuremberg, ao se afirmar que : "crimes against international law are committed by men, not abstract entities, and only by punishing individuals who commit such crimes can the provisions of international law be enforced" (Decisão do TMI, p. 41).

379 MENON, Theodore. "The humanization of humanitarian law". AJIL, 94, 200 p. 239. Sobre a cláusula Martens, Corte Internacional de Justiça, "Legality of the threat or use of nuclear weapons", de 8 de julho de 1996, e TICEHURST, R. "The Advisory Opinion of the International Court of Justice on the legality of the threat or use of nuclear weapons " , War Studies Journal, Outono, 2, 1, 1996, pp. 107-118.

${ }^{380}$ CASSESE, Antonio. International Criminal Law, op. cit., p. 5.
} 
claros (relativos, por exemplo, às condições objetivas e subjetivas do crime - actus reus e mens rea), assim como suas penas. Essa situação fica clara na atuação dos tribunais internacionais que se baseiam no seu estatuto e que previram uma série de crimes que deveriam ser punidos. Entretanto, esta série de crimes não foi enumerada nem previamente descrita com o rigor e a sistematização de código penal, mas simplesmente como a especificação da competência judiciária do tribunal em questão. Foi comum, portanto, o uso do texto que atribui competência para um tribunal internacional processar determinados crimes para fundamentar o entendimento daquela corte sobre o tipo legal que seria julgado $^{381}$; c) e decorre simultaneamente do direito internacional humanitário e dos direitos humanos, assim como do direito penal comum. Isso porque, diante da escassez de tratados, reconheceu-se a transposição gradual ao nível internacional das regras próprias do direito penal nacional. Como uma nova área jurídica, é essencialmente híbrida: direito internacional público impregnado pelas noções, princípios e construções jurídicas derivadas do direito penal comum, do direito internacional humanitário e dos direitos humanos. Desta forma, são considerados crimes de direito internacional ou crimes internacionais próprios os crimes de guerra, os crimes contra a humanidade, genocídio, tortura, agressão.

\subsubsection{Crimes contra o direito internacional}

No contexto da mundialização das relações sociais, econômicas, culturais, a internacionalização da intervenção penal depende da precisão do motor que fará suas instâncias atuarem: o conceito de crime internacional próprio ou crimes contra o direito internacional. Assim, a definição de crime internacional próprio é essencialmente a razão de ser dos Tribunais Penais Internacionais, e que passa pela face repressiva da proteção dos direitos humanos, por um novo formato das relações internacionais e pela construção de uma dogmática própria para o direito penal internacional. Conforme adverte DELMAS-MARTY, a proteção dos direitos humanos marca, primeiramente, os limites do poder de punir dos Estados (recurso de incriminar, mas também condição dos processos, da condenação, da

${ }^{381}$ GIL GIL, Alicia. Derecho Penal Internacional, p. 67. Nesse sentido, critica a autora o uso de artigos que determinam a competência de um tribunal penal internacional como sendo a descrição típica acabada do crime. 
escolha e da execução da pena), logo os limites ao movimento de penalização por que passam os direitos humanos e sua proteção em âmbito internacional ${ }^{382}$.

Dedicou-se a doutrina a estudar as questões relativas à competência internacional examinando a universalidade do direito de punir, o acordo internacional para a busca, a prisão e o julgamento dos acusados, assim como sobre a noção de comunidade internacional em direito penal e os limites impostos pela soberania do Estado ${ }^{383}$. Afirma-se, nesse sentido, que a aplicação da lei penal internacional deve deixar de ser apenas uma cortesia entre os Estados para se tornar simplesmente uma questão de direito e justiça, rompendo com a tradição jurídica "segundo a qual a ajuda mútua repressiva resulta tradicionalmente apenas de acordos feitos entre soberanos preocupados em fazer obra de alívio recíproco aceitando entregar seus inimigos pessoais" 384 .

Os crimes de direito internacional ou crimes internacionais próprios são aqueles nos quais existe a atribuição de uma responsabilidade penal fundada diretamente nas fontes do direito penal internacional, que ainda assim fazem parte dos crimes de transcendência internacional. Os outros crimes de transcendência internacional mas que não decorrem do direito penal internacional são aqueles que o direito internacional não tipifica a conduta, mas que obriga o Estado a criminalizar determinada conduta. Com referência a esses crimes internacionais impróprios, ao realizar a conduta típica, ela será punível conforme a lei nacional que a houver tipificado, que indiretamente respalda o interesse da comunidade em relação à persecução desta conduta. Pode-se enquadrar nesse caso, as iniciativas internacionais de repressão ao tráfico de pessoas, tráfico de entorpecentes, lavagem de dinheiro, tráfego aéreo e marítimo.

A repercussão da conduta pode se dar como consequência natural dos resultados normais, atingindo o bem-estar da comunidade internacional, caso em que estaríamos diante dos crimes de direito internacional, ou quando por estratégia de repressão, a comunidade internacional decida enfrentá-la em conjunto, nos demais casos de crimes de transcendência

\footnotetext{
382 DELMAS-MARTY, Mireille; CASSESE, Antonio. Crimes internacionais e jurisdições internacionais. Barueri: Ed. Manole, 2004.

${ }^{383}$ DONNEDIEU DE VABRES, Henri. Les príncipes modernes du droit penal international, Sirey, 1928, p. 403, apud BAZELAIRE; Jean-Paul; CRETIN, Thierry. A justipa penal internacional - sua evolução, seu future, de Nuremberg a Haia. Barueiri: Ed. Manole, 2004, p. 17.

${ }^{384}$ Idem, ibidem, p. 17.
} 
internacional ou transnacionais. Assim, o critério da repercussão internacional depende de um conjunto de variáveis que combinam elementos característicos da conduta e o resultado típico da ação, mas também opção do Estado por incluir a conduta no rol entre os crimes que pretende que seja reprimido em conjunto com outros Estados.

\subsubsection{Conflito na consolidação do direito penal internacional}

O fato de se buscar a integração em uma área nova de elementos do direito internacional humanitário e dos direitos humanos, instrumentalizados para aperfeiçoar no plano internacional a atribuição de responsabilidade penal, sem dúvida, apresenta dificuldades. Ao mesmo tempo em que o direito penal e o direito internacional se unem para criar condições de punição para os crimes que de forma mais grave e intolerável atingem a comunidade internacional, numa relação de subsidiariedade ou apoio mútuos, existe por outro lado, a dificuldade no que diz com dogmáticas e princípios fundamentais conflitantes. O direito penal internacional pretende a punição dos autores de crimes ao mesmo tempo que busca garantir seus direitos contra acusações e punições arbitrárias, correspondendo a uma de suas principais exigências a de que os tipos sejam tão precisos, claros e detalhados quanto possível. Resulta disso que qualquer pessoa tem o direito a saber se sua conduta, ex ante, é criminalmente proibida ou permitida. E, em outra medida, de maneira complementar, que ninguém será punido por uma conduta que não seja considerada criminosa no momento em que ela foi praticada.

A questão que se coloca é se o direito penal internacional estaria jungido à obediência de uma estrita legalidade ampla e flexível, compatível com as fontes do direito costumeiro, próprias do direito internacional público. Isso porque o Estatuto do TPI traz, no art. 38, como base normativa do direito penal internacional aplicado pelo TPI tanto as normas escritas como as não escritas ${ }^{385}$. E isso traz um descompasso evidente entre o valor da norma para o direito penal e para o direito internacional público: para o direito penal, o efeito repressivo da norma supera seu efeito normativo ou declaratório, por atribuir poder punitivo a um ente determinado para o exercício do poder de atribuição de responsabilidade

385 BASSIOUNI, M. Cherif. Introduction to the ICC Law, op. cit., 2003, p. 2-4; AMBOS, A parte geral do DPI. Bases para uma elaboração dogmática, op. cit., 2006, p. 35; WERLE, G. Tratado de derecho penal internacional, op. cit., 2005. 
e consequências no campo penal. Para o direito internacional, o poder normativo é mais importante do que sua função repressiva ${ }^{386}$. No direito internacional clássico, criado para resolver conflitos entre Estados soberanos, o processo legislativo é fluido e gradual, construído por regras frequentemente soltas, por meio dos costumes ou até mesmo das "soft laws", entendidas como padrões ou orientações desprovidas de força vinculante. O poder da norma escrita, assim, não decorre do conteúdo do que ela prescreve, mas do que ela consegue, a partir da construção de consenso entre os Estados, alinhar e organizar comportamentos. Resulta disso certa desconfiança e desconforto em aceitar que normas de conteúdo punitivo não cumpram com os requisitos da máxima legalidade.

De toda forma, o direito penal internacional não se forma e não se executa como os poderes do Estado nacional, sendo bastante razoável que ele seja aplicado, construído e compreendido de forma distinta. Basta considerarmos que não há um poder legislativo mundial que legitime a criação de suas normas, que inexiste um poder judiciário universal que funcione com um orçamento aprovado e financiado por tributos de seu próprio EstadoNação para cumprir suas próprias leis, que não possui uma polícia com poder e a atribuição de proteger a segurança mundial e garantir a proteção dos valores da paz, segurança e bemestar da comunidade internacional. Além disso, as instituições nacionais gozam de estabilidade, estrutura e pessoal dedicado a cumprir seu papel nas áreas da justiça criminal, inclusive na obtenção dos efeitos preventivos do crime. Contrariamente, a jurisdição criminal internacional não possui instituições com poderes semelhantes, de maneira estável e cujo império seja capaz de exercer um poder dissuasório para os crimes de sua competência, restando ao sistema a realização das funções retributivas e, nas palavras de BASSIOUNI, justo merecimento, onde o objetivo de reabilitação e integração social é remoto $^{387}$, muito embora possa fazer uso de forma eficiente das técnicas relacionadas à justiça de transição, conforme abordamos no capítulo 2. Ou seja, funciona nos dois limites do espectro de funções da pena: reconciliação (por meio da justiça de transição) e puro retributivismo (por meio da execução das penas de prisão do direito penal internacional) ${ }^{388}$.

\footnotetext{
${ }^{386}$ Conforme arguta observação de CASSESE, Antonio. International Criminal Law, op. cit., p. 8.

${ }^{387}$ Conforme BASSIOUNI, M. Cherif. "International Criminal Justice in the Age of Globalization", op. cit., p. 88 (trad. livre).

${ }^{388}$ Os efeitos preventivos das normas de direito penal internacional serão abordados no capítulo $4^{\circ}$, ao tratarmos da crítica aos institutos e funcionamento da área em relação à realização dos direitos humanos.
} 
O sistema de justiça criminal internacional não será aperfeiçoado como resultado de uma ação plenamente concertada, planejada e estruturada, construído de uma forma não ordenada, sujeita a eventos fortuitos, exigências práticas a incrementar os objetivos que se quer atingir, aliado à necessidade de se fortalecer a prática de cooperação interestatal, em direção a uma harmonização de prática e uniformização de normas e procedimentos. Ainda assim, BASSIOUNI entende que os dois sistemas, nacional e internacional, baseiam-se nas mesmas fundações filosóficas. MONTIEL, entretanto, entende que para se aplicar ao direito penal internacional um sistema ampliado de fontes em relação ao direito penal clássico, um sistema que aceita a validade de normas não escritas e incertas, a despeito da inderrogabilidade do princípio da legalidade, seria necessário renunciar à irrenunciável ideia de que o poder punitivido deve necessariamente possuir limites e que a justiça não apenas pode se restringir a uma dupla missão: a punição infinita e a impunidade zero ${ }^{389}$.

Ainda assim, CASSESE aponta dois eixos de grande mudança dentro do próprio direito penal internacional, reconhecendo a elevada velocidade com que seus contornos têm sido ampliados ao mesmo tempo que suas garantias fortalecidas. Segundo o renomado autor francês, recorrentes atrocidades continuam a vicejar no mundo atual, com a difícil contenção dos fatos pela força que não seja a militar. Entretanto, o que era um emaranhado pouco consistente de regras jurídicas começa a ganhar corpo com razoável coerência e, se no passado buscava a realização da justiça substantiva, atualmente ganha força a tendência de fundamentar a punição no princípio da estrita legalidade. Felizmente é uma tendência que vai de encontro a um dos princípios essenciais do moderno direito penal, de controle do poder arbitrário do Estado e proteção do cidadão que somente poderão ser condenados por fatos considerados crime após estes serem considerados crimes por meio de normas vinculantes.

\footnotetext{
389 MONTIEL, Juan Pablo. "La 'mala costumbre' de vulnerar derechos humanos: análisis y pronóstico de la costumbre como fuente del dpi”. In: MONTIEL, Juan Pablo. La crisis del principio de legalidad en el nuevo derecho penal: ¿decadencia o evolución?, Madri: Marcial Pons, 2012, p. 400.
} 


\subsection{O direito penal internacional e suas fontes}

\subsubsection{A questão da norma costumeira em direito penal internacional}

O direito penal internacional é um ramo do direito internacional público em construção. As fontes do direito internacional ${ }^{390}$ são bastante distintas das do direito penal ${ }^{391}$ e devem ser reavaliadas e redimensionadas para o entendimento do direito penal internacional.

Para o direito internacional, suas fontes estão enumeradas no Estatuto da Corte Internacional de Justiça - CIJ, art. 38, indicando que a CIJ deve aplicar: a) as convenções internacionais, b) o costume internacional, c) os princípios gerais de direito reconhecido pelas nações civilizadas e d) as decisões judiciárias e a doutrina. Não se trata apenas de uma indicação dos fundamentos nos quais se baseia a CIJ, mas um consenso universal $^{392}$ de referência para o direito internacional.

O Estatuto do TPII estabelecia de forma semelhante a aplicação do direito convencional e do direito costumeiro: "O direito aplicável apresenta-se sob a forma de regras do direito convencional e de regras do direito costumeiro", afirmando o Secretário Geral da ONU que o Estatuto deve se limitar aos crimes internacionais baseados "nas disposições dos instrumentos internacionais em vigor e, em relação ao princípio do nullum crimen sine lege, o TPII considerou aplicar “(...) as regras do direito internacional humanitário que fazem parte sem nenhuma dúvida possível do direito costumeiro, de maneira que o problema decorrente do fato de que certos Estados, mas não a totalidade deles, adiram às convenções específicas não se coloca"393.

\footnotetext{
${ }^{390}$ CASSESE, Antonio. International Law. Oxford: Oxford University Press, 2005, pp. 153 ss.

${ }^{391}$ Que decorre do princípio nullum crimen nulla poena sine lege. Sobre o princípio da legalidade em direito penal, v. ROXIN, Claus. Derecho Penal - Parte General, T. 1, Civitas, Madri, 1997, pp. 137 ss. (Trad. DiegoManuel Luzón Peña, Miguel Díaz y García Conlledo e Javier de Vicente Remesal).

${ }^{392}$ Cf. DAILlIER, P.; PELLET, A. Droit international public, 6a ed., LGDJ, 1999, par. 59.

${ }^{393}$ Relatório do Secretário Geral DOC ONU S/25704, §§ 17, 33 e 34, Resolução do Conselho de Segurança 827/1993 que criou o TPII, o Relatório do Secretário Geral, S/1995/134, par. 12. Os julgamentos do TPIR, caso Akayesu, TPIR (96-4-T), de 2 de setembro de 1998, cap. 6.5, do TPII, Exceções Preliminares, caso $D$. Tadic (IT-94-I-AR72), de 2 de outubro de 1995, §§ 128-37. Também o julgamento da Apelação do caso $D$. Edermovic (IT-96-22-A), de 7 de outubro de 1997.
} 
O Estatuto do TPI, por seu turno, também confirma a aplicabilidade das fontes clássicas no direito penal internacional, nos termos do art. 21:

"1. O Tribunal aplicará:

a) Em primeiro lugar, o presente Estatuto, os Elementos Constitutivos do Crime e o Regulamento Processual;

b) Em segundo lugar, se for o caso, os tratados e os princípios e normas de direito internacional aplicáveis, incluindo os princípios estabelecidos no direito internacional dos conflitos armados;

c) Na falta destes, os princípios gerais do direito que o Tribunal retire do direito interno dos diferentes sistemas jurídicos existentes, incluindo, se for o caso, o direito interno dos Estados que exerceriam normalmente a sua jurisdição relativamente ao crime, sempre que esses princípios não sejam incompatíveis com o presente Estatuto, com o direito internacional, nem com as normas e padrões internacionalmente reconhecidos.

2. O Tribunal poderá aplicar princípios e normas de direito tal como já tenham sido por si interpretados em decisões anteriores.

3. A aplicação e interpretação do direito, nos termos do presente artigo, deverá ser compatível com os direitos humanos internacionalmente reconhecidos, sem discriminação alguma baseada em motivos tais como o gênero, definido no parágrafo $3^{\circ}$ do artigo $7^{\circ}$, a idade, a raça, a cor, a religião ou o credo, a opinião política ou outra, a origem nacional, étnica ou social, a situação econômica, o nascimento ou outra condição."

Embora não se refira explicitamente à norma costumeira, percebe-se um alargamento das fontes de direito para o direito aplicável pelas cortes, abrangendo o direito interno dos diferentes sistemas jurídicos existentes, os princípios e normas clássicos do direito internacional e do direito internacional humanitário. Por fim, considera-se quiçá a maior fonte do direito aplicável pelo TPI "os direitos humanos internacionalmente reconhecidos", ainda que não se saiba precisamente quais as fontes próprias destes mesmos direitos humanos ${ }^{394}$, mas atuando sobretudo como uma confirmação do papel dos direitos humanos para o direito internacional em vigor.

Apesar de os direitos humanos se realizarem preferencialmente no âmbito nacional, por ação do Estado, nos casos de violações massivas produzidas por indivíduos sob as ordens ou serviço do Estado, o Estado não serve para proteger sua população vitimada. Apresenta-se, assim, a esfera internacional como uma rede de proteção para atuar em casos extremos. Assim, devemos contar com as portas abertas da jurisdição internacional.

${ }^{394}$ SIMMA, B.; PAULUS, A. "Le rôle relatif des différentes sources du droit international pénal (dont les príncipes généraux de droit). In: ASCENCION, H.; DECAUX, E.; PELLET, A. Droit International Pénal. CEDIN Parix X. Paris: Pedone, 2000, p. 57. 
Se a proteção dos direitos humanos contra os mais violentos e massivos ataques está na gênese e como objetivo fundamental da construção do direito penal internacional, os direitos humanos também limitam a própria atuação do direito penal internacional, da mesma forma que limitam a atuação dos demais poderes nacionais e internacionais, como é típico da relação entre o exercício dos poderes punitivos e os direitos humanos.

Mas há que se ver com ressalvas a aplicação do direito costumeiro em direito penal internacional, pois até bem pouco tempo atrás sempre foi princípio clássico em direito internacional a validade da norma internacional para o Estado, visto que se entendia que o indivíduo não era sujeito de direitos no plano internacional, inclusive por força das disposições das Convenções de Genebra. Ainda assim, a norma costumeira atribuindo reflexos no campo penal (notadamente, normas com conteúdo penal) foi reconhecida em diversos documentos internacionais, como os relatórios e julgamentos dos tribunais ad hoc, visto que a conduta praticada corresponderia a um crime, independente de tratados, ratificações e leis específicas nacionais. Mas a regra costumeira que se quer aplicar não é a do reconhecimento internacional de que uma conduta criminosa é criminosa para todo o ordenamento mas, sim, duas regras: a) a de que a conduta criminosa é criminosa na ordem internacional e atinge os mais altos bens jurídicos da comunidade internacional; e b) de que pela regra da complementariedade, um tribunal terceiro pode processar, julgar e condenar os atos praticados. Assim, pretende-se defluir do reconhecimento de uma conduta é criminosa e assim ela deve ser recebida pela ordem internacional, o fato de que ela está em condições de ser aplicada em toda sua complexidade pelas instituições do sistema judicial penal internacional.

Reconhece-se há poucos antecedentes de repressão aos crimes em direito internacional com base na norma costumeira de direito penal internacional - quando um dos requisitos para se construir um costume e se adensar a norma costumeira seria a aplicação consistente da norma. Conforme aponta SIMMA e PAULUS, o direito convencional do direito internacional penal também sofre da ausência de um sistema coerente que tivesse organizado o conjunto de suas normas. Cita, por exemplo, as normas que reprimem os atos de tortura conforme previstos na Convenção contra a Tortura e Outros Atos ou Tratamento Desumanos, Cruéis, ou Degradantes (Convenção contra a Tortura), embora os atos 
praticados pelo Estado não estejam abrangidos textualmente. Também há que se mencionar o tipo aberto denominado crime contra a humanidade, apenas previsto textualmente no Tribunal de Nuremberg, cujas incidências criminais não são direta e claramente aplicáveis e da Convenção para a Prevenção e a Repressão do Crime de Genocídio, de $1948^{395}$ (Convenção contra o Genocídio), sem um contornos e consequências claros no plano criminal claros.

Os tratados e demais instrumentos vinculantes internacionais, produzidos por pessoas jurídicas de direito internacional, trazem as clássicas vantagens da clareza, precisão, vigência, bem como do indubitável compromisso das partes signatárias aos seus termos, além da legitimidade que o seu conteúdo possui ao ser internalizado pela maioria dos países. Ainda que não sejam ratificados pela universalidade dos países, o fato de serem instrumentos escritos e de amplo acesso torna seu conteúdo claro e de conhecimento geral, inclusive como ponto de partida ou de chegada para o desenvolvimento de um costume ${ }^{396}$. O próprio Estatuto do TPI representa a fonte central do direito penal internacional, completado pelos elementos dos crimes e regras de procedimento do Tribunal. Nos termos do art. 9.1 do Estatuto, os elementos constitutivos dos crimes auxiliarão o Tribunal a interpretar e a aplicar os artigos $6^{\circ}, 7^{\circ}$ e $8^{\circ}$. O Estatuto do TPI é, assim, complementado pelos Elementos do Crime, um documento, embora não um tratado, adotado pela Assembleia dos Estados Partes do TPI em 9 de setembro de 2002 e que descreve as condutas abrangidas pelos crimes de competência do Tribunal.

O Estatuto, para WERLE ${ }^{397}$, confirma e precisa o direito penal em vigor segundo o direito internacional consuetudinário e, indo além da sistematização do direito consuetudinário, contribui autonomamente para o desenvolvimento progressivo do direito penal internacional. Mas também há aspectos em relação aos quais o Estatuto foi aquém em relação ao estado atual do direito internacional consuetudinário, especificamente sobre a criminalização dos meios proibidos de combate nos conflitos armados internacionais, já previstos e puníveis no âmbito do direito internacional humanitário e das Convenções de

\footnotetext{
${ }^{395}$ Decreto $\mathrm{n}^{\text {o }} 30.822$, de 6 de maio de 1952, promulga a convenção para a prevenção e a repressão do crime de Genocídio, concluída em Paris, a 11 de dezembro de 1948, por ocasião da III Sessão da Assembleia Geral das Nações Unidas.

${ }^{396}$ SIMMA e PAULUS, op. cit., p. 59. Inclusive diante da expansividade própria do direito penal pelos direitos humanos, por meio da jurisdição universal para casos de crimes contra o direito internacional.

${ }^{397}$ Cf. WERLE, Gerhard. Tratado de derecho penal internacional, op. cit., p. 112-3.
} 
Genebra. A importância do Estatuto do TPI já foi objeto de confirmação inclusive pelo próprio TPII ${ }^{398}$, antes até de sua entrada em vigor.

O costume internacional, embora seja carente da formalidade e segurança jurídica que os tratados trazem, são aplicáveis a todos os Estados - entretanto, para fundamentar uma persecução penal, o costume deve ter suficiente grau de certeza e segurança ${ }^{399}$. Em termos de regra penal, essa fonte do direito poderia violar a regra explícita do Pacto Internacional dos Direitos Civis e Políticos, art. $15^{400}$, que trata do princípio nullum crimen sine lege, que remete o reconhecimento da conduta ilícita pelo direito nacional, internacional ou pelos princípios gerais de direito aceitos pela comunidade de nações e a partir daí a atribuição de responsabilidade penal pelo seu descumprimento. Assim tanto o costume internacional quanto os princípios gerais de direito têm em comum o fato de que eles não são formalizados, mas derivados do comportamento dos Estados, de declarações de opinião e do direito nacional.

$\mathrm{O}$ direito costumeiro tem se alterado significativamente em relação à sua concepção clássica. Ele decorria da observação do comportamento reiterado do Estado, produzindo no ambiente internacional uma justa expectativa de que a obediência a essa regra pudesse ser juridicamente reivindicada. Ocorre que nem sempre se consegue acompanhar os comportamentos e sua evolução em todos os Estados, servindo de orientação para a

\footnotetext{
${ }^{398} \mathrm{Cf}$. § 227: "In many areas the Statute may be regarded as indicative of the legal views, i.e. opinio juris of a great number of States. Notwithstanding article 10 of the Statute, the purpose of which is to ensure that existing or developing law is not "limited" or "prejudiced" by the Statute's provisions, resort may be had cum grano salis to these provisions to help elucidate customary international law. Depending on the matter at issue, the Rome Statute may be taken to restate, reflect or clarify customary rules or crystallize them, whereas in some areas it creates new law or modifies existing law. At any event, the Rome Statute by and large may be taken as constituting an authoritative expression of the legal views of a great number of States." Caso Furundzija, decisão de 10 de dezembro de 1998 (IT-95-17/1-T),

${ }^{399}$ Para ZILI, Marcos, a mudança do paradigma punitivo, da transposição da legalidade positivada para outra fundada no costume, não implica relativização das exigências que devem pautar o direito penal. Assim, o exercício do direito penal pressupõe necessariamente a identificação de todos os seus elementos integrantes, ou seja, "o reconhecimento de uma prática reiterada e generalizada em grau, dimensão e profundidade que possam tornar evidente e incontroversa a sua ampla aceitação. É o mínimo que se espera da atuação de qualquer poder punitivo". ZILI, Marcos. "Punir or not punir? Qual é o verdadeiro dilema?", Revista Anistia, vol. 9, p. 353.

400 Assim, o art. 15 prevê que: "1. ninguém poderá ser condenado por atos ou omissões que não constituam delito de acordo com o direito nacional ou internacional, no momento em que foram cometidos. Tampouco poder-se-á impor pena mais grave do que a aplicável no momento da ocorrência do delito. Se, depois de perpetrado o delito, a lei estipular a imposição de pena mais leve, o delinquente deverá dela beneficiar-se. 2 . Nenhuma disposição do presente Pacto impedirá o julgamento ou a condenação de qualquer indivíduo por atos ou omissões que, momento em que forma cometidos, eram considerados delituosos de acordo com os princípios gerais de direito reconhecidos pela comunidade das nações" (grifo nosso).
} 
expectativa justa de comportamento os contatos diplomáticos em ambiente das organizações internacionais. Ainda mais em direitos humanos, nota-se um distanciamento do direito internacional em relação ao comportamento efetivo dos Estados nacionais e das práticas de direitos humanos, podendo-se afirmar a existência de uma "crise de identidade" 401 por que passa o direito costumeiro.

O caso entre Nicarágua e Estados Unidos é particularmente importante na fixação do entendimento e da prática do direito costumeiro em sede de direito internacional. Conhecido como o Caso envolvendo Atividades militares e Paramilitares na e contra a Nicarágua, a Corte Internacional de Justiça (decisão de 27 de junho de 1986) condenou os Estados Unidos por "treinar, armar, equipar, financiar e fornecer as forças contrárias ou de qualquer forma encorajar, apoiar e ajudar militarmente e paramilitarmente atividades na e contra a Nicarágua, por atuar contra a Nicarágua, violando suas obrigações sob o direito costumeiro internacional de não intervir nos assuntos de outro Estado, não utilizar a força contra outro Estado e não violar a soberania de outro Estado. Em voto separado, o juiz Nagendra Singh, então presidente da CIJ, relembrando o princípio cardinal do não uso da força como o ponto fulcral da filosofia jurídica que evoluiu após as duas grandes guerras mundiais, afirma que a Carta das Nações Unidas assim como o sistema de tratados da América Latina não apenas desenvolveram o conceito mas fortaleceram-no de tal modo que ele se sustentaria mesmo se a Carta ou o tratado de base fossem considerados inaplicáveis nesse caso. A razão óbvia é a de que o aspecto costumeiro original que deu origem ao desenvolvimento do direito dos tratados chegou agora para ficar e sobreviver como um conceito moderno existente de direito internacional, ainda que seja costumeiro, por causa de suas origens, ou "um princípio geral de direito internacional reconhecido pelas nações civilizadas" ${ }^{\prime 402}$. A função da Corte, segundo o voto de seu presidente, é o de enfatizar o princípio do não uso da força como pertencente ao âmbito do jus cogens e, portanto, um dos pilares para a promoção da paz.

Como um princípio que se funda essencialmente pelo conteúdo material de sua norma, para além dos aspectos formais, a norma costumeira impõe-se aos Estados, ainda que

401 SIMMA, B.; ALSTON, P. "The process of law-making is thus turned into a self-contained exercise in rhetoric", Austr. Y.B.I.L., vol. 12, 1992, p. 89.

402 V. Military and Paramilitary Activities in and against Nicaragua (Nicaragua v. United States of America), v. http://www.icj-cij.org/docket/index.php?sum=367\&p1=3\&p2=3\&case=70\&p3=5 (Acesso 14.11.2014). 
eles não tenham firmado tratados, ou inclusive repudiem expressamente o conteúdo da norma, ou, como uma das teses de defesa, nesse caso, o da legítima defesa coletiva. Por isso, sustenta-se que seu conteúdo deva ser de grande envergadura e respaldada pelo máximo interesse da comunidade internacional. Entretanto, para a atribuição de responsabilidade penal, há que se superar diversas instância até que se confirme sua vigência para o indivíduo, não bastando a afirmação de que a norma deve proteger os mais relevantes interesses da comunidade internacional e de que conta com o apoio desta. Os critérios de certeza e vigência devem ser ponderados e explicitamente identificados nas decisões, consoante veremos. Ademais, pesa o fato de que somente se tem utilizado o direito costumeiro para fundamentar punições e não para justificar absolvições. A este respeito, abordaremos o caso Edermovic $^{403}$, quando a alegação de estado de necessidade não lhe serviu para excluir a punibilidade.

A maior referência ao direito costumeiro moderno criminalizante encontra-se no julgamento de Dusko Tadic pela Câmara de Apelação do TPII (Caso Tadic), inclusive utilizando as fontes de costume internacional e princípio geral como intercambiáveis (par. 125 da decisão de 2 de outubro de 1995). Desta feita, o indivíduo é atado à norma de direito costumeiro, originalmente destinada à avaliação do comportamento dos Estados (como no caso citado acima, envolvendo Nicarágua e Estados Unidos). A decisão percorre a evolução histórica da formação do direito costumeiro aplicável em conflitos armados, partindo das regras de que não é ilimitado, num conflito, o direito das partes de causar dano ao inimigo, bem como o de que em todo o momento deve-se distinguir as pessoas engajadas em hostilidades da população civil ${ }^{404}$, conforme Resolução 2444 sobre Princípios básicos para a proteção das populações civis nos conflitos armados. O Departamento de Defesa dos Estados Unidos posteriormente apontou que esta resolução seria "declaratória de direito internacional consuetudinário" ou, em outras palavras, "uma correta reconfirmação" de "princípios de direito internacional consuetudinário" 405.

A defesa de Tadic argumentou que embora a norma consuetudinária vigore para a atuação das partes em um conflito armado e proíba certos comportamentos, essas

\footnotetext{
${ }^{403}$ Caso Erdemovic, TPII (IT-96-22-A), de 7.10.1997.

${ }^{404}$ Nos termos da Resolução n ${ }^{\circ}$ 2444, aprovada por unanimidade, da Assembleia Geral da ONU, em 1968, posteriormente confirmada na Resolução 2675, de 1970, sobre "Princípios básicos para a proteção das populações civis nos conflitos armados".

${ }^{405}$ V. American Journal of International Law, vol. 67, 1973, pp. 122-4.
} 
proibições não causam responsabilidade penal. Mas o TPII, fazendo referência ao TMI de Nuremberg, relembra que "a ausência de norma convencional sobre sanções de violação não exclui a responsabilidade penal individual" ${ }^{\circ 06}$. Cita, ademais, diversos casos da prática internacional por meio das quais os Estados pretenderam punir violações graves às regras e princípios consuetudinários ${ }^{407}$.

Tendo o Conselho de Segurança adotado resoluções condenando as violações ao direito internacional humanitário geral em situação de conflitos armados internos que conduzam à responsabilidade penal dos autores ou de seus mandantes, está-se a caminho da formação de uma opinio juris sobre o tema e de cristalização como direito internacional consuetudinário, ao lado das demais regras de proteção às vítimas. A decisão também entende que as considerações acerca da responsabilidade penal individual em caso de graves violações ao direito humanitário decorre também da aplicação dos valores de justiça e equidade substantivas ${ }^{408}$, assim como eram consideradas violações às próprias normas do Código Penal da República Socialista da Iugoslávia.

Ocorre que em termos de costume internacional, não cabe ao juiz criar uma regra, mas reconhecer ou identificar uma prática aceita como válida para o direito, a ser firmemente explicitadas como forma de garantir a objetividade das decisões vis à vis a explicitação da norma encontrada. MONTIEL, entretanto, aponta dois problemas nesse processo: a) muitas vezes os juízes acabam justificando a decisão com base no costume, tendo realizado interpretações extensivas ou ainda carregadas de subjetivismo devido a inferências lógicas a partir das fontes preestabelecidas; b) por outro lado, e talvez como consequência dessa artificialidade do recurso à fonte costumeira, utilizam um processo argumentativo e probatório deficitário. Assim, como forma de compensar a flexibilidade do princípio da legalidade com o recurso ao costume como fonte de direito, dever-se-ia ter

\footnotetext{
406 Conforme $\S 128$ da decisão (trad. livre). V. The Trial of a Major War Criminals: Proceedings of the International Military Tribunal Sitting at Nuremberg Germany, vol. 22, pp. 445-447, 467, 1950.

407 Conforme $\S \S 106$ e 125 da decisão, citando declarações da República Democrática do Congo, de 21.10.1964, sobre a conduta a ser seguida na condução de hostilidades, o "Código Operacional de Conduta para as Forças Armadas da Nigéria", de julho de 1967, para os mesmos efeitos na repressão à rebelião de Biafra. Também os rebeldes contra o governo de El Salvador declararam cumprir o art. 3 comum da Convenção de Genebra e seu Protocolo Adicional II. Também a Comunidade Europeia, em uma declaração de 2.08.1990, em relação às hostilidades da Libéria, exorta a que as partes em conflito respeitem os princípios humanitários para proteger da violência as embaixadas, lugares de refúgio como igrejas, hospitais, por exemplo (European Political Cooperation Documentation Bulletin, Seç. 6, p. 295, 1990, trad. livre).

${ }^{408}$ V. $§ 135$ da decisão.
} 
previsto um maior dever de fundamentação, com o máximo rigor e elementos de convencimento, acompanhada do devido processo, em cada caso. Contudo, conforme o autor, no afã de garantir a paz internacional, a segurança e a proteção dos direitos humanos, deixou-se de dar a devida atenção ao rigor e precisão aos elementos objetivos e subjetivos ${ }^{409}$.

Essa questão torna-se ainda mais tortuosa quando se analisam os fundamentos para a atribuição de responsabilidade por participação ou co-autoria. Entendeu-se que poderia ser aplicada a teoria da empresa criminal conjunta (joint criminal enterprise), que tem por base a pluralidade de pessoas que atuam de acordo com um mesmo plano, desenho, ou propósito para o cometimento de um crime. Em vista da falta de contorno preciso e dada a tendência de exagero na inclusividade dos imputados para não correr o risco de inclur de menos, podem surgir condenações por uma contribuição negligente, ou por uma contribuição que não execute nenhuma das ações do crime ${ }^{410}$. Se o acusado apenas contribuir com o plano, ainda que a contribuição não seja substancial, mas meramente uma forma simples de contribuição, pode ainda haver condenação pela teoria da empresa criminal conjunta. No caso Tadic, ela se liga ao conceito de coautoria, parecendo em outros casos referir-se à participação ou à responsabilidade acessória, reconhecida pela Corte de Apelação do TPII como tendo base costumeira, quando diversos países aproximam-se mais da teoria do domínio do fato do que da empresa criminal conjunta, como Suíça, Alemanha, Espanha, Argentina, Estados Unidos, Colômbia, entre outros. Outros casos, entretanto, reconheceram a teoria do domínio do fato, à diferença do caso Tadic, correspondendo à empresa criminal conjunta uma forma residual de responsabilidade acessória - e não como critério de aferição de coautoria ${ }^{411}$.

Em todo caso, o direito costumeiro tem sido utilizado para reconhecer a norma que proíbe uma conduta considerada crime para o direito penal internacional, mas também para fundamentar outras regras que determinam o dever de punir, como a responsabilidade por participação ou coautoria, a competência do tribunal, a reduzida margem de alegações para as defesas. Claro é que dificilmente um juiz de um tribunal internacional reconheceria

\footnotetext{
${ }^{409}$ Caso Furundija, TPII, Caso Krstic, TPII,

${ }^{410}$ Caso Broanin, Julgamento, Câmara de Apelação, TPII (IT-99-36-A), de 3 de abril de 2007, § 427 e 430. Caso Kvocka, Julgamento, Câmara de Apelação, TPII (IT-98-30/I-A), de 28 de fevereiro de 2005, §§ 97 e 187 , evitando que se requeira que a contribuição seja significativa.

${ }^{411}$ Caso Lubanga e Katanga, TPIR.
} 
a incompetência de uma corte que ele aceitou integrar, em relação a fatos que ele aceitou julgar.

\subsubsection{Princípios Gerais de Direito em Direito Penal Internacional}

Em relação aos princípios gerais de direito, o Estatuto do TPI separou os princípios gerais do direito internacional dos princípios gerais do direito nacional. Os princípios de direito nacional estão presentes tanto nos sistemas civilistas e de common law de modo mais uniforme possível na forma de direito aplicável ${ }^{412}$, embora nem sempre cheguem às mesmas conclusões e que isso redunde em que todos os sistemas devam ser avaliados para se chegar ao termo comum. Mas necessariamente, mais uma vez, o princípio deve dar conta de corresponder à realização dos valores de justiça e equidades substantivas. A questão de fundo, em relação aos princípios de direito nacional, é em que medida eles devem ser adaptados para corresponder à ordem jurídica internacional ${ }^{413}$ ? A resposta, mais uma vez tendente à universalização, seria a que de forma genérica exprimisse o direito nacional em consonância com os princípios de direitos humanos internacionalmente aceitos e que, no caso concreto, confirmasse a realização dos valores de justiça e equidade substantivos, mas também as garantias processuais, sobretudo aquelas recepcionadas pelo sistema internacional de proteção dos direitos humanos. Nesse quadrante, há que se dar um peso maior aos princípios em relação a uma norma específica, como valores organizadores de um sistema normativo, como critérios abstratos e genéricos por meio dos quais o direito há de se impor.

Com relação aos princípios gerais do direito internacional, no primeiro caso julgado pela Corte Internacional de Justiça - CIJ, do Estreito de Corfou, entendeu-se que os compromissos poderão se basear não somente sobre os tratados e o costume, mas também sobre "certos princípios gerais e bem reconhecidos, como as considerações elementares da humanidade" 414 . CASSESE inclui os princípios gerais do direito penal como princípios

\footnotetext{
${ }^{412}$ A relação entre os dois sistemas foi particularmente tratada no julgamento do caso Erdemovic, TPII, (IT96-22-A), de 7.10.1997, op. ind. Mc Donald e Vohrah, par. 56 e 76; op. ind. e diss. Stephen, § 25.

${ }^{413}$ V. BROWLIE, I. Principles of International Law, $5^{\mathrm{a}}$ edição, Claredon Press: Oxford, 1998, p. 16.

${ }^{414}$ Estreito de Corfu, CIJ, Recueil 1949, p. 22 (trad. livre).
} 
gerais do direito penal internacional, especificamente os princípios da legalidade, da especificidade, da presunção de inocência, da igualdade de armas e da responsabilidade de comando, presente do direito internacional humanitário, que são princípios geralmente vindos do direito nacional e que se trasladam ao plano internacional pela generalidade e reconhecimento de sua vigência ${ }^{415}$.

O princípio da especificidade, embora seja uma decorrência do princípio da legalidade, em direito internacional ainda não é plenamente observado, ou pelo menos, observado deficitariamente, sendo o maior exemplo disso o primeiro artigo da Carta de Londres de 1945 que previu que crimes contra a humanidade abrangiam ainda "outros atos desumanos", fórmula que foi repetida em diversos outros instrumentos ${ }^{416}$. O atual Estatuto do TPI ainda reescreve essa disposição prevendo que o crime contra a humanidade pode incluir outros atos desumanos de características semelhantes, dando contornos menos imperfeitos ao conceito de crimes contra a humanidade, embora ainda sem atingir a taxatividade exigida pelo cânone da legalidade. Outro exemplo é o uso recorrente das expressões como "graves ofensas", ou "tratamento desumano", nas Convenções de Genebra, de 1949.

Mas não poderia ser maior exemplo de falta de especificidade ou da própria legalidade o recurso ao direito costumeiro como fonte de direito penal internacional, conforme mencionamos acima, mas que progressivamente vem sendo escrito, como é exemplo o próprio Estatuto do TPI, bem como os delineamentos que as decisões judiciais têm produzido para concretizar o preceito jurídico. Conforme CASSESE ${ }^{417}$, as regras de direito penal internacional pelo menos por enquanto conformam um corpo jurídico que ainda carece de precisão legal e, em alguma medida, requer maior refinamento no que diz respeito às definições e princípios gerais. Nesse sentido, e de modo a resguardar os direitos do acusado, algumas excludentes de punibilidade podem ser invocadas, de maneira inclusive mais favorável do que no direito nacional, como as defesas relacionadas ao erro de proibição, ao princípio da interpretação estrita da norma, a evitar a construção extensiva ou ampla da incidência da norma penal, o princípio do in dubio pro reo ou favor rei.

\footnotetext{
${ }^{415}$ CASSESE, Antonio. International Criminal Law, op. cit., p. 20 ss.

${ }^{416}$ Lei ${ }^{\circ} 10$ do Conselho de Controle, o Estatuto do Tribunal de Tóquio, o Estatuto do TPII, TPIR e de Serra Leoa.

${ }^{417}$ CASSESE, Antonio. International Criminal Law, op. cit., p. 41.
} 
Por sua vez, a influência do princípio da legalidade na atividade de interpretação serve para limitar o poder de juízes não investidos cercearem a autonomia individual ilegitimamente, assegurando o respeito à tripartição dos poderes do Estado, sem usurpar das atribuições do poder legislativo, distintas necessariamente das atividades de interpretação e aplicação da lei típicas do poder judiciário. Há autores, entretanto, que em nome do princípio da justiça substancial, invoca-o em termos absolutos, justificando tratar-se de um ambiente distinto do doméstico, regido por diferentes normas e princípios. Assim, fórmulas vagas são preferidas em relação às descritivas rígidas, sob o argumento de poderem de forma mais fácil adaptar-se a novas circunstâncias, e na falta de um poder legislativo internacional, com a faculdade de criar regras obrigatórias a todos os cidadãos, temos os tratados no âmbito das Nações Unidas que obrigam todos os países, signatários ou não ${ }^{418}$.

O art. 21.3 do Estatuto do TPI estabelece que a aplicação e a interpretação da lei devem ser consistentes com os direitos humanos reconhecidos internacionalmente, dandose a impressão de se criar o que Pellet ${ }^{419}$ chamou de "super-legalidade", uma superioridade normativa que em muitos casos pode levar a contradições, conforme abordaremos no capítulo final: o dever de punir ou o dever de punir dentro da lei, dentro de parâmetros ínsitos à ideia de mínimo ético. Embora haja pouca reflexão a respeito da relação entre as regras de interpretação e os direitos humanos internacionalmente reconhecidos ${ }^{420}$ para efeitos de ponderação na decisão da corte, nota-se que ironicamente a redação do art. 21 buscou afirmar o respeito do TPI ao princípio da legalidade, limitando a discricionariedade judicial na interpretação e aplicação do Estatuto. Há, portanto, que se contemporizar os efeitos dessa "super-legalidade", como padrão de objetivo dos sistemas jurídicos, mas reconhecendo que o princípio da legalidade é ainda o pilar central do regime do Estatuto, o que seria seriamente prejudicado se, como no passado, um vasto corpo normativo não definido pelo Estatuto fosse usado para se ampliar o escopo da responsabilidade criminal individual em direito internacional $^{421}$, conforme o art. 32 da Convenção de Viena, sempre que uma interpretação levar a uma condenação ilegal, produzindo, pelo uso dos mecanismos de interpretação de

\footnotetext{
${ }^{418}$ RAZ, J. The authority of law, 1979, pp. 214-215.

419 PELLET, “Applicable Law", in CASSESE, Antonio et al. (eds). The Rome Statute of the ICC: a commentary, 2002, pp. 1051, 1080.

${ }^{420}$ GROVER, Lena. "A Call to Arms: Fundamental Dilemmas Confronting the Interpretation of Crimes". The European Journal of International Law, vol. 21, n 3, 2010, p. 559.

${ }^{421}$ Idem, pp. 559-560.
} 
maneira equivocada, "um resultado manifestamente absurdo ou irrazoável” (art. 32, "b”, da Convenção de Viena).

A grande maioria dos países membro das Nações Unidas reconhecem a irretroatividade da lei penal em suas Constituições ${ }^{422}$, assim como muitos desses, a irretroatividade da lex gravior e mesmo aqueles que não firmaram o Pacto Internacional de Direitos Civis e Políticos da ONU também reconhecem esse princípio. De modo geral, esses princípios são aceitos como parte do direito costumeiro internacional, pois o direito costumeiro não deve servir somente para confirmar uma norma punitiva, mas também e especialmente para convocar as diversas matrizes jurídicas que evitam o exercício do poder arbitrário, do poder que se realiza para além dos limites clássicos do exercício do poder punitivo. Portanto, trata-se de um princípio a fazer parte do panorama de princípios que norteiam o direito penal internacional, e que se encontra enunciado no ETPI da seguinte forma: "Artigo 24 - Não há retroatividade ratione personae. 1. Nenhuma pessoa será considerada criminalmente responsável (...) por uma conduta anterior à entrada em vigor do presente Estatuto 2. Se o direito aplicável a um caso for modificado antes de proferida sentença definitiva, aplicar-se-á o direito mais favorável à pessoa objeto de inquérito, acusada ou condenada."

Outro princípio cuja discussão é cara a esse tema diz respeito à responsabilidade dos chefes militares e outros superiores hierárquicos, enunciado pelo art. 28 do ETPI. O princípio relativo à responsabilidade por comando com base no direito internacional foi pela primeira vez anunciado no caso Yamashita afirmando que a responsabilidade por comando é uma consequência da quebra das obrigações que recaem sobre os seus comandados naturalmente, obrigações de ordem penal, mas que da forma tal como enunciada não representa a melhor formulação de um princípio que autoriza a incriminação de um indivíduo $^{423}$. O caso foi levado à Suprema Corte dos Estados Unidos, que sustentou que os comandantes tinham a obrigação de adotar medidas adequadas e dentro do seu âmbito de

${ }^{422}$ GALLANT cita todas as Constituições dos países e seus respectivos artigos a esse propósito. GALLANT, Kenneth S. "La legalidade como norma del derecho consuetudinario internacional la irretroatividade de los delitos y de las penas". In: MONTIEL, Juan Pablo. La crisis del principio de legalidad en el nuevo derecho penal: ¿decadencia o evolución?, Madri: Marcial Pons, 2012, p. 320-322, nota 17.

${ }^{423}$ General japonês Yamashita foi o comandante geral do exército japonês nas Filipinas de 1943-5, quando foram reportadas grandes atrocidades cometidas por seus soldados, como o massacre em larga escala da população civil da Província de Batangas, atos de violência, assassinatos, saques e pilhagem e destruição de monumentos religiosos. 
poder para controlar as tropas sob seu comando e prevenir as violações ao direito de guerra, com base inclusive nas Convenções de Genebra de 1929 e na Convenção de Haia de 1907, que expressamente estabelece que os combatentes devem ser comandados por uma pessoa responsável por seus subordinados e, em assim sendo, o comandante de uma força ocupante de um território inimigo "deve tomar todas as medidas em seu poder para restaurar e assegurar, tanto quanto possível, a ordem pública e a segurança, ao mesmo tempo que respeitar as leis em vigor no país, a menos que seja absolutamente impossibilitado".

O princípio da responsabilidade por comando foi consolidado a partir da II Guerra Mundial, cristalizado a partir do direito costumeiro, prevê que: a) a existência de uma obrigação dos comandantes militares, assim como civis ou líderes civis, de evitar ou reprimir os crimes cometidos por seus subordinados se eles soubessem ou devessem saber que as tropas estivessem em vias de cometer, cometendo ou já tivessem cometido esses crimes; b) a obrigação de criminalizar o descumprimento desta norma, especificando elementos de mens rea. Gradualmente, a responsabilidade por comando foi sendo reconhecida como decorrência da culpabilidade própria do agente ${ }^{424}$.

Também no caso Tadic, o TPII referiu-se explicitamente às "considerações elementares da humanidade, e do bom senso" 425 como justificativa para a aplicação das normas sobre conflitos armados internacional aos conflitos internos sem indicar outra fonte de direito, justificando adiante que "os princípios e regras de direito humanitário refletem 'as considerações elementares da humanidade' largamente reconhecidas como o mínimo obrigatório para a conduta de toda sorte de conflitos armados". Os princípios gerais de direito podem ser considerados para a verificação ou falsidade das regras de direito consuetudinário internacional em formação, e em consequência, ainda não consolidadas e, na esteira de opiniões atualizadas preponderantes, esses princípios podem se fundamentar na valoração do conjunto de soft law praticada em direito internacional ${ }^{426}$, tal como reconhecido no julgamento pelo TPII, fundamentando a condenação dos ataques a civis em campos de batalha como um crime, em sentido semelhante ao citado em relação ao caso Tadic, por se

\footnotetext{
${ }^{424}$ Cf. art. 87 do Primeiro Protocolo Adicional, 1977, sobre "Obrigações dos comandantes". Também encontrase prevista em diversos manuais militares, como o suíço, Réglement (1987), art. 196, Manual Militar Russo (1990), parte VII, par. A e b, Manual Militar alemão (1992), cap. 1, nº 138, Manual do Direito dos Conflitos Armados francês (2001), introdução e "Responsabilité des supérieurs et devoirs des commandants", p. 84. ${ }^{425}$ Caso Tadic, TPII (IT-94-1-AR72), 2 de outubro de 1995, par. 119 (trad. livre).

${ }^{426}$ AMBOS, Kai. Parte geral do direito penal internacional, op. cit., p. 47 ss.
} 
tratar de um “clamor por humanidade e os ditames da consciência pública, como manifestado na opinio necessitatis ${ }^{\prime 427}$, em detrimento dos argumentos de que se constituiria a praxe dos Estados em operações militares.

Restava saber, assim, se um princípio geral poderia fundamentar a existência de um crime. Para essa discussão, remete-se ao julgamento do caso Furundzija, no qual a câmara de julgamento do TPII buscou identificar a existência ou não de uma regra de direito internacional costumeiro que definisse o crime de estupro. Diante da inexistência de tal regra, recorreu-se ao ordenamento local, no qual se reconheceu a definição articulada de estupro. Para o tribunal, o recurso à legislação local é justificado diante das seguintes condições $^{428}$ : a) a menos que seja indicado por uma regra internacional, a referência não deve ser feita a apenas um sistema legal nacional apenas, de common law ou civilista. Ao contrário, os tribunais internacionais devem recorrer a conceitos gerais e instituições legais comuns a todos os maiores sistemas do mundo; b) sendo certo que os julgamentos internacionais apresentam características que os diferenciam dos processos criminais nacionais, deve-se considerar essa especificidade nos processos criminais internacionais ao utilizar noções de direito nacional, evitando-se a transposição ou importação de uma lei nacional que possa levar a distorções do sentido e razão de ser do direito penal internacional.

A dúvida que existia era a se também poderiam ser criminalizadas as condutas de penetração oral apuradas no curso do processo. Textualmente: "A maior divergência pode, contudo, ser encontrada na criminalização da penetração oral forçada: alguns Estados tratam-no como agressão sexual, enquanto ele é classificado como estupro em outros Estados. Confrontado com esta falta de uniformidade, cabe ao juízo estabelecer se uma solução apropriada pode ser alcançada por meio do recurso aos princípios gerais de direito penal internacional, ou, se tais princípios não servirem, para os princípios gerais do direito internacional." ${ }^{429}$.

Embora o estupro seja caracterizado majoritariamente como penetração vaginal, a Câmara entendeu que a penetração forçada oral é o maior, mais humilhante e degradante ataque à dignidade humana. Justifica-se, assim, que a essência de todo o corpus jurídico do

\footnotetext{
${ }^{427}$ Prosecutor v. Kupreskic e outros. Julgamento 14.1.2000 (IT-95-16-T), par. 527 ss (trad. livre).

${ }^{428}$ Caso Furundzija, TPII (IT-95-17/1-T), decisão de 10 de dezembro de 1998, § 178,

${ }^{429}$ Caso Furundzija, TPII (IT-95-17/1-T), decisão de 10 de dezembro de 1998, § 182 (trad. livre).
} 
direito internacional humanitário assim como dos direitos humanos recaia sobre a proteção da dignidade humana de qualquer pessoa ${ }^{430}$. A invasão do corpo humano de maneira forçada representa uma inaceitável violação da autodeterminação da pessoa, com carga máxima de agressão moral e humilhação, e que estaria em consonância com o princípio geral da dignidade humana a classificação de violência sexual, tal como a penetração oral forçada, como estupro, reafirmando a Câmara não ser contrária ao princípio do nullum crimen sine lege, mesmo quando a lei nacional enquadra essa conduta como violação sexual e não por estupro. Considerando a ausência de norma internacional específica, procurou no contexto internacional uma base principiológica que embasasse a condenação pelo crime de estupro, a ser reconhecido inclusive por força do art. 21.3 do Estatuto do TPI, que estabelece que a aplicação e interpretação do direito será compatível com os direitos humanos internacionalmente reconhecidos. Isso se dá pelo limitado escopo de competência atribuído aos tribunais internacionais, os quais ao definirem quatro tipos penais, não conseguem dar conta de todas as violações extremamente graves que ocorrem nos contextos de conflito, interno ou externo, uma ampliação que seria impensável no direito nacional (analogia in malam parten). Assim é que a tipificação de um crime não está encerrada unicamente no Estatuto do TPI, mas também presente em outros instrumentos do direito internacional (art. 22.3).

Tem-se, portanto, que para o direito penal internacional, o fato de existirem normas escritas não quer dizer que, por si, que estas normas não exaurem todos os atos contrários ao interesse fundamental da comunidade internacional em proteger os direitos humanos mais relevantes. Tanto pela via do costume internacional, quando dos princípios gerais de direito, procura-se captar o conteúdo da norma incriminadora, quando o respeito ao princípio da legalidade representa três consequências: 1) um sentido do interesse da comunidade internacional em punir aquela conduta descrita ou outra que se assemelhe muito a ela; 2) uma barreira que poderá ser transposta pelo tribunal internacional a depender das justificativas lançadas na fundamentação de sua decisão; 3) um argumento da defesa com poucas chances de encontrar guarida.

${ }^{430}$ Caso Furundzija, TPII (IT-95-17/1-T), decisão de 10 de dezembro de 1998, § 183. 


\subsection{O TPI e a interpretação das normas de direito penal internacional}

\subsubsection{Interpretação no direito penal internacional}

O tema da interpretação dos tratados deve ser estudado a fim de verificar como são aplicadas as normas de direito internacional penal. A interpretação clássica segue as normas da Convenção de Viena sobre o Direito dos Tratados, de $1969^{431}$, e seus artigos 31 e 32 estabelecem que:

Art. 31

Regra Geral de Interpretação

1. Um tratado deve ser interpretado de boa-fé segundo o sentido comum atribuível aos termos do tratado em seu contexto e à luz de seu objetivo e finalidade.

2. Para os fins de interpretação de um tratado, o contexto compreenderá, além do texto, seu preâmbulo e anexos:

a) qualquer acordo relativo ao tratado e feito entre todas as partes em conexão com a conclusão do tratado;

b) qualquer instrumento estabelecido por uma ou várias partes em conexão com a conclusão do tratado e aceito pelas outras partes como instrumento relativo ao tratado.

3. Serão levados em consideração, juntamente com o contexto:

a) qualquer acordo posterior entre as partes relativo à interpretação do tratado ou à aplicação de suas disposições;

b) qualquer prática seguida posteriormente na aplicação do tratado, pela qual se estabeleça o acordo das partes relativo à sua interpretação;

c) quaisquer regras pertinentes de Direito Internacional aplicáveis às relações entre as partes.

4. Um termo será entendido em sentido especial se estiver estabelecido que essa era a intenção das partes.

\section{Artigo 32}

Meios Suplementares de Interpretação

Pode-se recorrer a meios suplementares de interpretação, inclusive aos trabalhos preparatórios do tratado e às circunstâncias de sua conclusão, a fim de confirmar o sentido resultante da aplicação do artigo 31 ou de determinar o sentido quando a interpretação, de conformidade com o artigo 31 :

a) deixa o sentido ambíguo ou obscuro; ou

b) conduz a um resultado que é manifestamente absurdo ou desarrazoado.

${ }^{431}$ Promulgada pelo Decreto $n^{\circ} 7.030$, de 14 de dezembro de 2009. 
Trata-se da consolidação de regras costumeiras do direito internacional, mas que não exaure as técnicas de interpretação utilizadas pelos juízes internacionais, como a interpretação literal ${ }^{432}$, lógica ${ }^{433}$, contextual $^{434}$, efetiva ${ }^{435}$, conforme a vontade do legislador ${ }^{436}$, propositiva ${ }^{437}$ e progressiva ${ }^{438}$. Também os padrões de proteção dos direitos humanos ${ }^{439}$ para a defesa dos acusados têm sido invocados como orientações para os julgamentos.

A interpretação corresponde a um método geral de que se socorrem os aplicadores do direito para fundamentar suas decisões e encontrar a solução para a regra dialética do processo. As regras de interpretação foram utilizadas nos julgamentos do TPII, como vertido nas decisões dos casos Tadic ${ }^{440}$, Aleksovski $^{441}$ ou Mucic $^{442}$, entre outros ${ }^{443}$. O Tratado de Viena é referido para validar o uso dos trabalhos preparatórios como meio suplementar de interpretação, a ser utilizado nos casos em que um texto ou tratado de qualquer outro instrumento que crie uma norma internacional for obscura ou ambígua, nos termos do seu art. 32. A decisão do TPII orienta, assim, o recurso às regras de interpretação não apenas em relação a normas escritas, tratados, convenções (como disposição expressa

432 Casos Delalic, TPII (96-21-T), de 16 de novembro de 1998, $\S 161,170$ e 438; Tadic, julgamento, TPII (94-1-A), 15 de julho de 1999, § 296; Krstic, julgamento, TPII (98-33-T), 2 de agosto de 2001, §. 496, Kanyabashi, votos separados de McDonald e Vohrah, TPIR (96-15-A), 3 de junho de 1999, § 13.

${ }^{433}$ Casos Delalic, TPII (96-21-T), de 16 de novembro de 1998, §§ 166 e 400; Tadic, TPII (94-1-AR72), de 2 de outubro de 1995, §§ 79-95; Kanyabashi, voto discordante do juiz Shahabuddeen, TPIR (97-19-AR72), de 3 de novembro de $1999, \S 21$.

${ }^{434}$ Caso Delalic, supra, $\S \S 166$ e 438.

${ }^{435}$ Casos Kanyabashi, voto discordante do juiz Shahabuddeen, TPIR (97-19-AR72), de 3 de novembro de 1999, §§ 46 e 110; Tadic supra, § 284. Delalic, supra, §§ 164 e 170.

${ }^{436}$ Caso Akayesu, julgamento, TPIR (96-4-T), de 2 de setembro de 1998, § 516.

${ }^{437}$ Conforme SWART, "human rights courts have frequently employed the idea of the object and purpose of the treaties they interpret to support an expansive interpretation of the rights contained in those treaties. No Caso Tadić a Câmara de Apelação decidiu abandonar a definição literal de "pessoas protegidas" e, formulando uma interpretação propositiva, concentrou-se mais no fator de alinhamento (allegiance) do que na nacionalidade forma na determinação do regime protetivo. Caso Tadić (IT-94-1-A), 15.7.1999, §§ 163 ss. SWART, Mia. "Is There a Text in This Court? The Purposive Method of Interpretation and the ad hoc Tribunals". ZaöRV, 70, 2010, p. 780 ss.

438 Jelisic, julgamento, TPII (95-10-T), de 14 de dezembro de 1999, § 61, Kunarac, julgamento, TPII (IT- 9623 e 96-23/1-A), de 12 de junho de 2002, § 67; Simic, opinião dissidente do juiz Schomburg, TPII (95-9-A), de 28 de novembro de 2006, § 17.

${ }^{439}$ Furundzija, julgamento, TPII (95-17/1-T), de 10 de dezembro de 1998, § 183; Delalic, TPII (IT-96-21-T), de 16 de novembro de 1998 , $§$ 265-266.

${ }^{440}$ Caso Tadic, decisão de 15 de julho de 1999, § 303, Caso Tadic, decisão de 2 de outubro de 1995, §§ 71 ss.

${ }^{441}$ Caso Aleksovski, decisão de 24 de fevereiro de 2000, $\S 98$.

${ }^{442}$ Caso Mucic, decisão de 16 de novembro de 1998, § 158 ss.

${ }^{443}$ Caso Erdemovic, julgamento, voto separado dos juízes McDonald e Vohrah, TPII (IT-96-22-A), de 7 de outubro de 1997, § 3, Caso Basogora et al., TPIR (98-37-A), 8 de junho de 1998, §§. 28-29; Caso Dedalic e outros, julgamento (TPII 96-21-T), de 16 de novembro de 1998, § 1161. 
da própria Convenção), mas em relação a qualquer regra que crie uma norma internacional $^{444}$.

Dependerá da coordenação, na atividade interpretativa, dos elementos que consolidam a norma, escrita ou consuetudinária, em interação com as técnicas clássicas de interpretação. Ocorre que, para a as normas que criam uma proibição, elemento central das normas penais, a realização da interpretação pode fundamentar o reconhecimento de uma regra de proibição que contrarie os princípios do direito penal. Ainda que exista uma clara aproximação entre os crimes de direito internacional e a proteção internacional dos direitos humanos, inclusive por força do disposto no art. 21.3 do Estatuto do TPI, que estabelece que a aplicação do direito pelo TPI deve ser compatível com os direitos humanos internacionalmente reconhecidos, muito pouco se nota do uso dos princípios do direito penal para a contenção do viés criminal expansivo dos direitos humanos.

\subsubsection{O direito penal internacional e o recurso à analogia}

A analogia serve ao direito a partir da ideia que concebe o direito como um sistema de fins. Assim é que por meio do processo analógico, busca-se a solução jurídica pela integração normativa, estendendo-se a um caso não previsto aquilo que o legislador previu para outro semelhante, com base na semelhança dos fatos e na regra de direito que se abstrai. Isso porque pretende-se que o sistema do direito, ainda que ficticiamente, seja um todo integral e que forneça as soluções a todos os jurisdicionados, sendo justo que o cidadão espere solução semelhante sempre que haja, diante de casos análogos, uma identidade de razão jurídica, segundo um antigo e sempre novo ensinamento: ubi eadem ratio, ibi eadem juris dispositivo ${ }^{445}$.

\footnotetext{
${ }^{444}$ No original, "Under customary international law, as codified in Article 32 of the Vienna Convention referred to above, the travaux constitute a supplementary means of interpretation and may only be resorted to when the text of a treaty or any other international norm-creating instrument is ambiguous or obscure" (nosso grifo, decisão do caso Tadic de 15 de julho de 1999, IT-94-1-A).

${ }^{445}$ REALE, Miguel. Lições Preliminares de Direito. 27a ed. São Paulo: Saraiva. 2002, p. 296 e FITZMAURICE et all. (eds.) Treaty interpretation and the Vienna Convention on the Law of Treatis: 30 years on. Martinus Nijihoff., Leiden, 2010.
} 
Entretanto, a analogia é um método de integração normativa evitada por tribunais nacionais em direito penal, especialmente do sistema civilista, mas também pelos tribunais internacionais, para que cidadãos não sejam punidos por crimes que não existiam quando as respectivas condutas foram praticadas, evitando o arbítrio do Estado. Em matéria penal, por força do princípio da legalidade, não é permitido, por analogia, tipificar fatos que se localizam fora do raio de incidência da norma, elevando-os à categoria de delitos. Portanto, em relação às normas incriminadoras, as lacunas, porventura existentes, devem ser consideradas como expressões da vontade negativa da lei ${ }^{446}$. Esse é precisamente o sentido da legalidade compreendida como taxatividade, como dimensão normativa que persegue a concretização do mandato de determinação da lei penal, corolário lógico do postulado da certeza jurídica.

Essa vedação deve ser seguida pelo direito penal internacional, ainda que sejam fontes do direito para a corte penal internacional o direito costumeiro e os princípios gerais de direito. Tal é a previsão do art. 22.2 do Estatuto do TPI, dentro do artigo que define o princípio da legalidade, com o cuidado de prever que o tipo penal deverá ser estabelecido de forma precisa e sem o recurso à analogia e que nos casos de ambiguidade, a norma será interpretada a favor do acusado. Um exemplo de analogia não permitida foi a pretendida e rejeitada pelo Tribunal de Nuremberg ${ }^{447}$, no qual o Tribunal entendeu que a noção de crimes contra a humanidade não abrangia ofensas contra a propriedade, mantendo a vedação ao uso da analogia. Se, por meio da interpretação, o juiz tem o dever de interpretar e aplicar a lei, dando conteúdo de boa-fé ao texto legal, de acordo com seus significados ordinários ou especiais, contexto, propósito, a analogia seria uma forma de surpreender os cidadãos com a criação de um crime que não poderia ter sido previsto ${ }^{448}$, pelo menos, não enquanto norma de conteúdo penal plenamente vigente.

Os princípios gerais não podem criar uma proibição, quando não exista lei escrita, embora possa embasar ou auxiliar a definição dos contornos legais de uma regra presente no direito costumeiro ou nos tratados e, portanto, usados onde já houver regras, mas não para criar novas regras. A abertura de regras como "demais atos desumanos" ou "graves

${ }^{446}$ GRECO, Rogério. Curso de Direito Penal - Parte Geral. 4ª ed. Rio de Janeiro: Impetus. 2004, p. 48.

${ }^{447}$ Caso Flick e outros, $§ 1215$.

${ }^{448}$ LAMB, "Nullum crimen, nulla poena sine lege in International Criminal Law". In: CASSESE, Antonio et al. (eds.). The Rome Statute of the ICC: a Commentary, 2002, p. 753. 
violações" são, não obstante, permissões expressas ao uso da analogia, permitindo a integração de condutas que numa mesma escala de valores abrangidos, ataquem esses bens jurídicos com a mesma gravidade.

Autores sustentam que a vedação à analogia não deve prevalecer nos seguintes casos: a) quando se recorrer aos princípios gerais do direito penal internacional ou à justiça criminal, ou aos "princípios comuns aos maiores sistemas legais do mundo" para determinar se a conduta eventualmente punível é proibida segundo o direito dos tratados ou costumeiro $^{449}$; b) quando os dizeres do crime em si requer o recurso à analogia (por exemplo, "outros atos desumanos" ou "outros atos desumanos de características semelhantes") ${ }^{450}$; c) quando a leitura do texto legal, diante do seu objeto e propósito, demonstra a necessidade de se preencher seu conteúdo pela referência a outros artigos ${ }^{451}$.

Ademais das fontes obrigatórias, também são mencionadas as não obrigatórias, mas que auxiliam a determinar a existência das fontes reconhecidas e de ajuda à sua interpretação. Fazem parte deste segundo grupo os julgamentos internacionais e internos e também a doutrina, soft law e especialmente resoluções de órgãos internacionais, e a aplicação do direito interno ${ }^{452}$. Mas deve-se reconhecer com elogio que de forma mais integrada os princípios gerais têm sido levados em conta, tanto de direito nacional quanto de direito internacional, revelando uma cada vez maior e relevante sincronia sobre os valores fundamentais que norteiam a atuação do direito internacional o que, na opinião de SIMMA e $\operatorname{ALSTON}^{453}$, seria a mais importante contribuição do direito penal internacional ao direito internacional geral.

${ }^{449}$ CASSESE, Antonio. International Criminal Law, op. cit., p. 49.

${ }^{450}$ BROMHALL, “Article 22”. In: TRIFFTERER, O. (ed.), Commentary on the Rome Statute of the ICC, 2008, 713-717, 725. Também KUHLEN, Lothar, com base na jurisprudência da Corte Suprema Alemã, afirma que a vedação à analogia indica que a interpretação deve ser dada conforme o sentido literal possível, e, portanto, não pode ir além do que admite o fim e o contexto da norma. Desta forma, a vedação ao recurso da analogia não se entende apenas em sentido técnico estrito, mas sobretudo em relação à toda aplicação do direito que vá além do conteúdo de uma norma de sanção". KUHLEN, Lothar. "Sobre la relación entre mandato de certeza y la prohibición de la analogía". In: MONTIEL, Juan Pablo. La crisis del principio de legalidad en el nuevo derecho penal: ¿decadencia o evolución?, Madri: Marcial Pons, 2012, p. 160.

${ }^{451}$ Conforme o próprio Estatuto de Roma, ao fazer referência aos Elementos do Crime, que embora não seja um tratado, complementa o entendimento destes, foi adotado pela Assembleia dos Estados Partes ao Tribunal, de 9 de setembro de 2002 (ICC-ASP/1/3 - parte II-B).

${ }^{452}$ Para maior aprofundamento, NIJHOFF, Martinus, "The Structure and Process of International Law", The Hague, 1983, pp. 484 s.; SIMMA, B.; ALSTON, P. "The Sources of Human Rights Law: Custom, Jus Cogens and General Principles", Austr. Y.B.I.L.,vol. 12, 1992, pp. 82-102. Também, MERON, Theodor. Human Rights and Humanitarian Norms as Customary Law. Oxford: Clarendon Press, 1989.

453 "Sources du droit international penal", p. 68 
Em relação aos princípios gerais do direito nacional, AMBOS aponta para a dificuldade e parcialidade no desenvolvimento do método comparado de análise, contrapondo o método que adote como ponto de partida e centro de considerações o direito nacional para, no lugar deste, preferir-se o modelo funcional, como método de comparação válida para os fins pretendidos de cotejamento de uma conduta na esfera penal internacional para uma solução materialmente adequada ${ }^{454}$. Nesse sentido, o método funcional organiza as considerações empíricas segundo o papel e funções dos institutos jurídicos existentes, mais do que avalia estaticamente a solução dada para cada problema. O autor ainda recomenda o uso do princípio da comparação jurídica valorativa, do direito comunitário europeu, que orienta a maximização da proteção dos direitos fundamentais e que no plano internacional, levaria à maximização da proteção dos direitos humanos ${ }^{455} \mathrm{e}$, portanto, ao fortalecimento da norma repressiva em direito penal internacional. Como afirma AMBOS, o decisivo não é o regramento geral de uma questão, mas o plano dos princípios $^{456}$.

O Tribunal também está vinculado a suas próprias decisões, mas de maneira também relativa. Estando vinculado, não está obrigado a segui-las. Essa vinculação foi especialmente reconhecida em relação aos tribunais de Ruanda e Iugoslávia, tendo decidido a Câmara de Apelação do TPII que: "na falta de certeza e previsibilidade, a Câmara de Apelação deve seguir suas decisões prévias, mas deve ser livre para afastar-se delas por razões cogentes no interesse da justiça" ${ }^{457}$, refletindo uma tendência de não se afastar da orientação acolhida pelo tribunal a menos que razões de superior justiça se apresentem.

\footnotetext{
${ }^{454}$ AMBOS, Kai. Parte geral do direito penal internacional. Op. cit., p. 48.

455 AMBOS, Kai. Parte geral do direito penal internacional. Op. cit., p. 49.

${ }^{456}$ Conforme ALEXY, distinguindo princípios de regras, que faz sentido para a diferenciação proposta por AMBOS: "los princípios ordenan que algo debe ser realizado en la mayor medida posible, teniendo en cuenta las posibilidades jurídicas y fácticas. Por lo tanto, no contienen mandatos definitivos sino solo prima facie. Del hecho de que un principio valga para un caso no se infiere que lo que el principio exige para este caso valga como resultado definitivo. Los principios presentan razones que pueden ser desplazadas por otras razones opuestas. El principio no determina como ha de resolverse la relación entre una razón y su opuesta. Por ello, los principios carecen de contenido de determinación con respecto a los principios contrapuestos y las posibilidades fácticas". ALEXY, Robert. Teoría de los Derechos Fundamentales (Trad. por Ernesto Garzón Valdés). Madrid: Centro de Estudios Políticos y Constitucionales, 1993, p. 99. Por outro, "os princípios, nesta perspectiva, são verdades objetivas, nem sempre pertencentes ao mundo do ser, senão do dever-ser, na qualidade de normas jurídicas, dotadas de vigência, validez e obrigatoriedade". BONAVIDES, Paulo. Curso de Direito Constitucional. 12. ed. São Paulo: Malheiros, 2002, p. 228-229.

${ }^{457}$ Caso Aleksovski, TPII, decisão de 24 de março de 2000, § 107 (IT-95-14/1-A) (trad. livre).
} 
O recurso às decisões dos tribunais nacionais é uma regra importante do Estatuto, visto a possibilidade deixada aberta de promover uma integração do direito internacional com o direito nacional, reconhecida a interpenetração de seus sistemas ao invés de representarem categorias estanques que não se tocam. Como lembra WERLE, as decisões de tribunais nacionais exercem uma dupla função na determinação do direito: representam a manifestação do convencimento jurídico estatal, inclusive criando normas consuetudinárias da prática estatal e contribuem na consolidação dos princípios gerais de direito, mas também em outro sentido, esclarecem o conteúdo das normas de direito penal internacional como meio auxiliar de determinação do direito da forma que obriga (ou não) os cidadãos e o Estado nacional.

\subsection{Principais Elementos de Direito Penal Internacional}

\subsubsection{A evolução do conceito de responsabilidade individual em DPI}

Como abordado no início do capítulo, o conceito de crime contra o direito internacional pressupõe o reconhecimento da responsabilidade individual na esfera penal internacional, que teve sua primeira tentativa com o Tratado de Versalhes, mas que se realizou apenas nos Tribunais de Nuremberg e Tóquio. As Nações Unidas, por meio de sua Assembleia Geral, Resolução 95 (I) de 11 de dezembro de 1946, publicaram os princípios de direito internacional reconhecidos pelo Estatuto do Tribunal de Nuremberg, encorajando o desenvolvimento progressivo do direito internacional e de sua codificação. A publicação dos princípios bem como o apoio ao desenvolvimento de sua codificação podem ser traduzidos como o movimento por meio do qual a comunidade mundial colocou em marcha o processo de transformação dos princípios gerais de direito costumeiro aplicáveis aos Estados membros e a toda comunidade internacional ${ }^{458}$.

${ }^{458}$ CASSESE, Antonio. "Affirmation of the Principles of International Law recognized by the Charter of the Nüremberg Tribunal - General Assembly Resolution 95 (I)”. Disponível em http://legal.un.org/avl/ha/ga_95I/ga_95-I.html (Acesso 12.11.2014). 
A Comissão de Direito Internacional foi encarregada de dar expressão jurídica específica e genérica aos princípios de Nuremberg e em 1950 concluiu sua obra estabelecendo como Primeiro Princípio o de que "todo autor de um ato que constitua um crime de direito internacional é responsável pelo ato e passível de punição" ${ }^{459}$. Esse princípio decorre de forma imediata do julgamento do Tribunal Militar Internacional que afirma que "os crimes contra o direito internacional são cometidos por homens e não por entidades abstratas, e apenas por meio da punição dos indivíduos que cometem esses crimes podem as normas de direito internacional ser cumpridas" 460 .

O Princípio II, por sua vez, estabelece que "o fato de o direito interno não punir um ato que constitui um crime de direito internacional não afasta a responsabilidade em direito internacional pelo ato que cometeu" ${ }^{" 461}$. Este princípio reforça o disposto no Princípio I, sobretudo pelo fato de retirar a defesa pela falta de previsão legal e permitir a punição pelo direito costumeiro. Sua norma já vinha prevista no Estatuto do TMI, artigo 60 "cc", a respeito dos crimes contra a humanidade, ao definir como crimes certas condutas "fossem ou não (cometidas) em violação à lei nacional do país em que foram perpetradas". Ressaltando o valor deste princípio, o julgamento pelo TMI já havia declarado que "é da essência do Estatuto que indivíduos tenham deveres internacionais que transcendam as obrigações nacionais de obediência imposta pelo Estado de maneira isolada" ${ }^{462}$.

Esses princípios foram enunciados de maneiras semelhantes nos diversos documentos do direito penal internacional que se seguiram, como o Estatuto do TPII, art. $7^{\circ}$, par. $1^{\circ}$, do TPIR, art. $6^{\circ}$, par. $1^{\circ}$, vindo a constar inclusive do projeto de Código de Crimes contra a Paz e a Segurança da Humanidade, elaborado pela Comissão de Direito

\footnotetext{
${ }^{459}$ Trad. livre, a partir da publicação oficial: "Principle 1 - Any person who commits an act which constitutes a crime under international law is responsible therefor and liable to punishment". Yearbook of the International Law Commission, 1950, vol. II, para. 97. Disponível em: http://legal.un.org/ilc/texts/instruments/english/draft\%20articles/7_1_1950.pdf (Acesso 12.11. 2014).

${ }^{460}$ Trad. livre, da redação original: "crimes against international law are committed by men, not abstract entities, and only by punishing individuals who commit such crimes can the provisions of international law be enforced" (Decisão do TMI, p. 41).

${ }^{461}$ Trad. livre, a partir da publicação oficial: "The fact that internal law does not impose a penalty for an act which constitutes a crime under international law does not relieve the person who committed the act from responsibility under international law". Yearbook of the International Law Commission, 1950, vol. II, para. 97. Disponível em: http://legal.un.org/ilc/texts/instruments/ english/draft\%20 articles/7_1_1950.pdf (Acesso 12.11.2014).

${ }^{462}$ Trad. livre, da redação original: "the very essence of the Charter is that individuals have international duties which transcend the national obligations of obedience imposed by the individual state" (Decisão do TMI, p. 42).
} 
Internacional, de 1996, assim enunciado: "um crime contra a paz e a segurança da humanidade gera a responsabilidade individual" 463 . Essa regra foi reproduzida no Estatuto do TPI, em seu art. 25 , par. $2^{\circ}$, que prevê que: "quem cometer um crime da competência do Tribunal será considerado individualmente responsável e poderá ser punido de acordo com o presente Estatuto".

Entendeu-se que a apuração da responsabilidade individual daqueles que cometeram crimes de uma gravidade extrema diante de instâncias judiciais penais da comunidade internacional faria parte da opinio juris e que estaria de acordo com seu dever de garantir um nível mínimo de ordem pública internacional (mínimo ético), tendo os tribunais ad hoc rejeitado as exceções apresentadas pela defesa dos acusados contra o reconhecimento da responsabilidade individual ${ }^{464}$. Isso porque as bases para tal reconhecimento não decorrem de uma fonte formal de direito penal, mas do direito costumeiro, fonte do direito internacional, dentro dos critérios afirmados pela decisão da Corte Internacional de Justiça, Plataforma Continental do Mar do Norte ${ }^{465}$.

Para TOMUSCHAT, essa nova ordem pública internacional, que consagra a responsabilidade criminal individual na esfera internacional, instaura-se desde 1945 com a Carta das Nações Unidas, reflete o liame estreito que existe entre o respeito aos direitos humanos e a manutenção da paz internacional. Desta forma, "para fazer respeitar os direitos humanos, é necessário, em certas circunstâncias extremas, recorrer à arma do direito penal" ${ }^{\text {466 }}$. No seu entendimento, diante dos mais graves crimes a demandar uma sanção efetiva, se estivermos diante de um ou dois pilares do costume internacional, não se requer a mesma densidade para confirmar sua vigência do que se exigiria de regras que não decorrem diretamente de grandes princípios da ordem internacional contemporâneo.

Acrescente-se a isso a obrigação decorrente das Convenções de Genebra de 1949 a obrigar os Estados signatários a processar criminalmente os indivíduos acusados de terem

\footnotetext{
${ }^{463}$ Trad. livre. Draft Code of Crimes against the Peace and Security of Mankind, 1996, na versão original em inglês: "Article 2 Individual responsibility, 1. A crime against the peace and security of mankind entails individual responsibility." Disponível em http://www.un.org/law/ilc/ (Acesso em 03.12.2014).

${ }^{464}$ V. TPII, Caso Tadic (IT-94-1-AR72), 02.10.1995, par. 128-137; TPIR, Caso Kanyabashi, (96-15-T), 18.06.1997, § 35 .

${ }^{465}$ CIJ, Rec. 1969, p. 43.

466 TOMUSCHAT, C. "La cristallisación coutumière". In: ASCENCION, H.; DECAUX, E.; PELLET, A. Droit International Pénal. CEDIN Parix X. Paris: Pedone, 2000, p. 26-7.
} 
infringido de forma mais grave as disposições do direito internacional humanitário. A questão é de quando uma norma com efeitos domésticos (punição das infrações pelo direito nacional) passa a produzir efeitos internacionais. TOMUSCHAT afirma que o fato de se ter objetivado efeitos universais, por meio de uma regra que devesse ser adotada pela totalidade de Estados, conflitantes ou não, "parece fácil concluir que a obrigação de punir as infrações graves adquiriu valor de regra costumeira, assim como os outros elementos do regime humanitário de $1949 " 467$. Ainda assim, não se pode dizer que todos os governos apressaramse por fazer repercutir no ordenamento jurídico nacional os ditames das Convenções de Genebra. Os conflitos que ocorreram na ex-Iugoslávia, entretanto, contribuíram para o resgate de seus preceitos ${ }^{468}$, ainda que de maneira pontual, mas que diante do histórico retratado, e das normas convencionais, entende-se que a obrigação de sancionar penalmente as infrações às normas do direito humanitário de Genebra possuem tanto uma base convencional quanto um fundamento costumeiro. WERLE ${ }^{469}$ também concorda que muitas das disposições penais contidas nestes tratados são reconhecidas atualmente como direito internacional consuetudinário.

A responsabilidade individual é uma clara decorrência da regra da imputação no âmbito do direito penal internacional em consonância com o princípio da culpabilidade (nullun crimen sine culpa), conforme também reconhecido no julgamento pelo TPII contra Tadic ao decidir que:

\begin{abstract}
"O pressuposto básico deve ser que, em direito internacional, tanto quanto nos sistemas nacionais, a responsabilidade criminal funda-se no princípio da culpabilidade pessoal: ninguém pode ser responsabilizado criminalmente por atos ou ações nas quais ele não tenha se envolvido pessoalmente ou tenha de alguma outra maneira participado (nulla poena sine culpa). Em sistemas jurídicos nacionais este princípio está consagrado nas constituições, nas leis, ou em decisões judiciais. Em direito penal internacional o princípio está consagrado, nomeadamente, no artigo 7(1) do Estatuto do Tribunal Penal Internacional, que afirma que:
\end{abstract}

'Uma pessoa que planejou, instigou, ordenou, cometeu ou de qualquer forma ajudou ou incentivou no planejamento,

467 TOMUSCHAT, C. "La cristallisation coutumière", op. cit., p. 28, trad. livre.

${ }^{468}$ MASON, R. "Les premiers cas d'application des dispositions pénales des Conventions de Genève par les jurisdictions internes", European Journal of International Law, 1995, vol. 6, pp. 260-273.

${ }^{469}$ Cf. WERLE, Gerhard. Tratado de derecho penal internacional. Op. cit., p. 115. 
preparação ou execução de um crime previsto nos artigos $2^{\circ}$ a $5^{\circ}$ do presente Estatuto, será considerado individualmente responsável pelo crime (grifo no original da decisão)" ${ }^{\prime 470}$.

\subsubsection{A crítica aos elementos do direito penal internacional}

\section{a) Norma costumeira pro societate}

Para além do que mencionamos acima em relação à aplicação do direito costumeiro, está claro que ele pode ser reconhecido em relação aos crimes contra a humanidade, visto que as condutas agrupadas sob esta denominação estavam proibidas pelos códigos penais de todos os países civilizados, inclusive na Alemanha, cuja ditadura nazista não ousou abertamente reformar seu código penal para especificar os grupos de pessoas sujeitas à proteção da lei. Ainda assim, TOMUSCHAT reconhece a dificuldade em se afirmar que todas a condutas indicadas pelo art. $7^{\circ}$ do Estatuto do TPI sob a denominação de crime contra a humanidade teriam essa raiz costumeira que se reconhecia em sua origem, a saber, o Estatuto de Nuremberg e a codificação dos princípios de Nuremberg pela CDI, isso porque a definição foi sendo sucessivamente aumentada.

A definição do Estatuto de Nuremberg, art. 60, “c”, continha a previsão das seguintes condutas: assassinato, extermínio, escravização, deportação, outros atos inumanos cometidos antes da guerra ou durante ela, perseguição por motivos políticos, raciais e religioso na execução dos crimes de competência do Tribunal. O Estatuto do TPII, art. $5^{\circ}$, acrescentou: expulsão, prisão, tortura, violação e perseguições por motivos políticos, raciais e religiosos e outros atos desumanos. A conduta de perseguição, antes punível apenas quando atrelada a outros crimes de competência do Tribunal, passa a ser autônoma. Assim como "outros atos desumanos" cometidos num contexto de conflito militar, passam a ser punidos autonomamente a essa condição.

470 Julgamento da apelação, 15.07 .1999 (IT-94-1-A), § 186, trad. livre. Note-se que a referência ao Estatuto do TPI foi feita mesmo antes de sua entrada em vigor. 
O Projeto de Código de Crimes contra a Paz e a Segurança da Humanidade elaborado pela CDI, tal como previsto no art. 18, acrescenta: a perseguição por motivos étnicos, além de políticos, religioso ou étnicos, a discriminação institucionalizada baseada e motivos raciais, étnicos, religiosos que envolvam a violação dos direitos humanos e liberdades fundamentais, deportação arbitrária ou transferência forçada de população, prisão arbitrária, desaparecimento forçado de pessoas, e crimes sexuais, como estupro, prostituição forçada e outras formas de abusos sexuais e outros atos desumanos que ataca de modo mais grave a integridade física ou metal, a saúde ou a dignidade humana. O Estatuto de Roma (TPI) acrescentou ainda mais disposições, aumentando a abrangência da definição de crimes contra a humanidade. Em relação aos crimes sexuais, incluiu "gravidez forçada, esterilização forçada ou qualquer outra forma de violência no campo sexual de gravidade comparável". As condutas de perseguição foram ampliadas para abranger: "a perseguição de um grupo ou coletividade que possa ser identificado, por motivos políticos, raciais, nacionais, étnicos, culturais, religiosos ou de gênero (...), ou em função de outros critérios universalmente reconhecidos como inaceitáveis no direito internacional, relacionados com qualquer ato referido neste parágrafo ou com qualquer crime da competência do Tribunal. A disposição que remete a outros atos desumanos é assim prevista: “outros atos desumanos de caráter semelhante, que causem intencionalmente grande sofrimento, ou afetem gravemente a integridade física ou a saúde física ou mental”, sempre tendo como referência o artigo 5.1, que estabelece a competência do TPI para "os crimes mais graves, que afetam a comunidade internacional no seu conjunto".

A construção do direito costumeiro, a ocorrer de forma dedutiva, não permite a formulação de uma teoria geral dos crimes contra a humanidade a partir dele, viciando a captação teórica tendo como objetivo abranger todas as condutas condenáveis do ponto de vista dos direitos humanos, realçados à categoria de objeto de proteção internacional em função da escala (grande, ou mais graves, conforme o art. 5.1 do Estatuto do TPI) e forma de execução (generalizado ou sistemático, art. $7^{\circ}$ do Estatuto do TPI). 


\section{b) Princípio da Legalidade}

A realidade fez os tribunais internacionais atuarem dentro de um sistema rudimentar jurídico, havendo pouco mais do que a norma costumeira e as resoluções que criaram as cortes indicando que estas deveriam atuar de modo a colocar fim à impunidade diante dos graves crimes ocorridos em situações nas quais estes crimes não eram julgados. Sendo as regras de direito penal internacional não escritas, relativamente indeterminada, adaptáveis a novas circunstâncias e com certo grau de maleabilidade e flexibilidade ${ }^{471}$, os tribunais acabaram por criar o direito, estendendo a aplicação do direito humanitário a novas áreas e a atualizar o direito internacional humanitário, principalmente por meio da interpretação.

Essa atividade, ligada a uma interpretação aventureira, permite que o juiz preencha as lacunas ou mesmo a inexistência legislativa por uma atividade de produção do direito pela corte, impulsionada e justificada pela gravidade do caso $^{472}$. Essa atividade

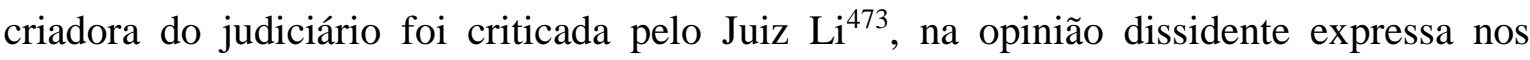
seguintes termos: a decisão (atacada) no Caso Tadic é uma presunção não autorizada de poderes legislativos que nunca foram conferidos ao TPII por qualquer autoridade.

Conforme MALARINO ${ }^{474}$, o maior problema que se coloca para a aceitação do direito costumeiro como fonte de direito para o TPI não é tanto o fato de não ser uma lex previa, mas principalmente o fato de não ser uma lex certa. Largamente usado para confirmar a ocorrência de um crime contra a humanidade na jurisprudência latino-americana, existe apenas uma certeza: a de que não existe certeza sobre quais são seus elementos constitutivos,

\footnotetext{
${ }^{471}$ SWART, Mia. "Is there a text in this court? The purposive method of interpretation and the ad hoc Tribunals". Zä̈RV, 70, 2010, p. 771.

${ }^{472}$ Segundo SWART, op. cit., p. 772, "tribunal judges have relied on the grave nature of the crimes in question as a justification for adventurous lawmaking”, referindo-se inclusive ao preâmbulo do Estatuto do TPI.

${ }^{473}$ Caso Tadic, decisão sobre a jurisdição do TPII, opinião separada do Juiz Li, § 13, de 2 de outubro de 1995, no original: “(...) I cannot agree with the Decision that Article 3 'confers on the International Tribunal jurisdiction over any serious offence [s] against international humanitarian law not covered by Article 2, 4 or 5' (Decision at p. 51, para. 91) and that 'the conditions to be fulfilled for Article 3 to become applicable' (Decision at p. 52, para. 94) may be laid down by the Decision. The Decision on this question is in fact an unwarranted assumption of legislative power which has never been given to this Tribunal by any authority" (grifo nosso).

${ }^{474}$ MALARINO, Ezequiel. "Jurisprudencia Latinoamericana sobre Derecho Penal Internacional". In: AMBOS, Kai; MALARINO, Ezequiel; ELSNER, Gisela (eds.), Jurisprudencia Latinoamericana sobre Derecho Penal Internacional, Montevideu: Konrad Adenauer, 2008, p. 445.
} 
especialmente em relação ao contexto, o que é fundamental pois são estes que alteram a conformação do crime de ordinário para de direito internacional. Concordamos com o autor: o recurso ao direito costumeiro deve ser reservado apenas a casos excepcionalíssimos, quando não existir dúvidas com relação à norma e aos seus elementos constitutivos, o que nem sempre se verifica quando se analisa a responsabilidade por comando, a existência da empresa conjunta criminosa, ou quando o tribunal pretende aplicar a teoria da previsibilidade de se saber que a conduta era criminosa. Um tribunal não pode restringir-se a missão de realizar um objetivo (colocar fim à impunidade $)^{475}$, mas realizar os meios para se atingir uma sociedade melhor pela gestão legal dos conflitos, seja pela realização de punições ou absolvições. A atribuição ex ante de um objetivo já a colocaria inclinada a realizar um tipo de julgamento e excepcionalmente outro ${ }^{476}$. Essa utopia aumenta a pressão na forma de atuação do tribunal e, muito especialmente, na orientação em favor da tese acusatória, sobretudo quando analisamos o teor das resoluções da ONU que criaram o TPII e o TPIR, na qual se lê a determinação de se "colocar um fim a estes crimes" e expressar a confiança de que a criação dos tribunais "permitirá que este objetivo seja atingido e que contribuiria para a restauração e a manutenção da paz" ${ }^{477}$. Esse tipo de aspiração comunica uma pressão a mais na articulação das normas que, no melhor dos cenários, levará à condenação dos acusados, comprometendo e maculando a imparcialidade da jurisdição internacional criminal.

Para tanto, basta afirmar que o uso da locução "graves crimes" serve para fundamentar a tipificação de crimes contra a humanidade, envolvendo nesse conceito toda sorte de condutas encontradas por ocasião das justificativas de punição. Assim, uma diversidade heterogênea de condutas, como furto, falsificação de documentos, subtração e ocultação de menor, foram considerados como crimes contra a humanidade no âmbito da

\footnotetext{
475 O objetivo do TPII, conforme afirmado em suas decisões, é o de "make all crimes against humanity punishable" (TPII, Caso Tadic, julgamento pela Câmara de Apelação, IT-94-I-A, de 15 de julho de 1999, § 285), ou o de "not to leave unpunished any person guilty of any war crime" (Caso Tadic, decisão do pedido da defesa sobre a jurisdição, Câmara de Apelação, IT-94-I-A, de 2 de outubro de 1995, § 92).

${ }^{476}$ Conforme BECCARIA: "pretende-se que um crime atroz cometido por exemplo em Constantinopla possa ser punido em Paris, pela razão abstrata de que aquele que fere a Humanidade merece ter todos os homens como inimigos e deve ser objeto de execração universal. No entanto, os juízes não são os vingadores da sensibilidade humana em geral, mas das convenções que ligam os homens entre si". Dos delitos e das penas, São Paulo: Ed. Revista dos Tribunais, 2011 (trad. José Cretella Jr. e Agnes Cretella), § XXI (1764).

${ }^{477}$ Res. CS/ONU 827/1993, preâmbulo, §§ 5 e 6; Res. CS/ONU 955/1994, §§ 6 e 7.
} 
CorteIDH, tornando-os imprescritíveis e determinando ao país que reabrisse o processo quando este já se encontrava transitado em julgado ${ }^{478}$.

Menciona-se, ainda, para a consideração de crimes contra a humanidade, diante do valor que esse conceito encerraria de proteção em máxima escala da dignidade humana, que diversas condutas que atentem contra esse valor, o da singularidade de cada ser humano e sua igual pertença à comunidade humana, poderiam ser considerados como crimes contra a humanidade. Nesse sentido, DELMAS-MARTY ${ }^{479}$ incluiria, a nossos ver, alargando excessivamente o conceito, deliberadas práticas políticas, jurídicas, médicas ou científicas que aparentemente respeitam a vida, mas que colocam em xeque a humanidade assim compreendida, em referência às modificações genéticas e práticas eugênicas. Entretanto, em verdade, a gravidade e a crueldade de que se revestem os casos investigados, e diante da dificuldade de se conseguir a detenção dos acusados e levá-los a um juízo, servem estes elementos de pressão para que, uma vez estando os acusados sub judice, aumente-se o desejo de se comunicar em alta instância institucional o direito internacional dos direitos humanos, e, com uma função pedagógica, na esperança desesperada de que isso tenha um efeito preventivo numa situação caótica. É comum chegarmos a pensar, como nos propõe ROBINSON $^{480}$, que o direito penal internacional procura compensar sua fragilidade jurídica diante da realidade dos graves fatos por meio de leis draconianas, ou, em outros termos, de sobre-compensar uma fraqueza material por meio de sua rigidez normativa, ou o mau direito por uma boa causa.

Mas não poderíamos tratar do princípio da legalidade sem fazer referência à diferença relevante que existe na forma de concebê-lo entre o direito de matriz civilista e o common law. Discute-se dentro do sistema do common law qual seria a extensão do que se entende por princípio da legalidade. Alguns entendem que se trata de regras contra a punição de uma pessoa por uma conduta sem uma lei que declare esta conduta criminosa (podendo ser uma lei escrita ou jurisprudencial ${ }^{481}$ ), outros que é uma regra contra a punição

\footnotetext{
${ }^{478}$ Casos Barrios Alto, Bulacio e Almonacid Arellano, CorteIDH.

${ }^{479}$ DELMA-MARTY, Mireille. Três Desafios para um Direito Mundial (trad. Fauzi Hassan Choukr). Rio de Janeiro: Lumen Juris, 2003, pp. 187-188

480 ROBINSON, Darryl. "The identity crisis of international criminal law", Leiden Journal of International Law, 21, 2008, p. 944.

${ }^{481}$ SIMESTER, A.P.; SULLIVAN, G.R. Criminal Law: Theory and Doctrine 38, Oxford: Hart Publishing, 2003.
} 
retroativa ${ }^{482}$, outros contra leis vagas para determinar uma conduta ofensiva ao direito ${ }^{483}$. Mas essencialmente diferente da forma como captamos o sentido de certeza e segurança que se desenvolve dentro de nossa tradição jurídica, WESTERN chega a afirmar que o princípio da legalidade estaria ligado ao próprio conceito de culpabilidade. Para o autor, o princípio da legalidade decorre da ideia de que "ninguém deve ser punido sem ter praticado um ato mau", e o princípio ainda deixa subjacente a máxima de que "qualquer pessoa presume-se inocente até que seja provada sua culpa" 484 . Portanto, o grau de certeza e objetividade que contornam o conceito de legalidade é significativamente diferente entre os principais sistemas jurídicos mundiais.

\section{c) O DPI e o Ius Cogens}

A natureza do direito penal internacional caracteriza-se por uma dupla ordem, com princípios e preceitos, mas sobretudo fontes, bastante diferentes: o direito penal e o direito internacional. A tessitura desta composição merece ser cuidadosamente elaborada sob pena de se construir um poder exacerbado sobre uma base frágil, contraditória, franqueadora de arbitrariedades, ou uma base sólida mas que não atinja seu objetivo, a saber, a punição dos mais graves crimes contra o direito do conjunto das sociedades. Para GIL GIL, com relação ao conteúdo de direito penal, a ele cumpre a proteção de bens jurídicos, em âmbito internacional, pela projeção de seu objeto e articulação interestatal. Estes bens pertencem ao direito internacional e revestem-se de uma importância social supranacional, ou seja, de condições necessárias para a conservação da ordem internacional. Em relação ao âmbito de aplicação, recorre-se ao direito internacional, vinculando todos os indivíduos de todos os Estados-Nação, pois a origem seria fonte do direito internacional.

Para GIL GIL, entretanto, não se trataria apenas do reconhecimento das normas substantivas pela maioria ou não dos Estados, mas do fato de gozar de um caráter de ius

\footnotetext{
482 ALLEN, Frank. "The erosion of legality in American Criminal Justice: some later-day adventures of the" "nulla poena principle"”, 29, Arizona Law Review 385, n 1, 1987.

${ }^{483}$ PACKER, Herbert. The limits of the criminal sanction, 72-73, Stanford: Stanford Univ. Press, 1968.

${ }^{484}$ WESTERN, Peter. "Two rules of legality in criminal law". Law and Philosophy, vol. 26(3), pp. 229-305, 2007 ,
} 
cogens, estando na seara das fontes de direito internacional, nos termos do art. 53 da Convenção de Viena de 1969 que define as normas imperativas como aquelas aceitas e reconhecidas pela comunidade internacional de Estados em seu conjunto, dotada de força vinculante, portanto, e que não admite acordo em contrário e que somente poderia ser modificada por norma posterior de mesmo caráter, ou seja, consensual. GIL GIL justifica tal posição por duas razões fundamentais: que se deve poder aplicar as normas de direito penal internacional independente da vontade dos Estados, uma vez que na maioria das vezes se trata exatamente de condutas executadas dentro de uma ação governamental e, em segundo, que se vinculam diretamente os cidadãos de todo o mundo, com independência da vontade dos Estados a que pertençam.

Estamos tratando, portanto, da aplicação em sede penal de uma norma de aplicação geral, universal, instantânea uma vez reconhecida como ius cogens, a qualquer cidadão do planeta, independentemente da formalização de qualquer documento, controle de legalidade, adesão estatal. O cuidado ressaltado pelos internacionalistas é de que o ius cogens da norma internacional é dirigido aos Estados e não diretamente visando a atribuição de responsabilidade penal individual em direito internacional ${ }^{485}$. No mesmo sentido, as obrigações das Convenções de Genebra eram dirigidas aos Estados, atribuindo o dever destes reprimirem penalmente as infrações ao direito internacional humanitário, segundo o direito nacional aplicável, as infrações graves ao direito genebrês e de punir ou extraditar os indivíduos que violassem essas regras (aut dedere aut judicare) ${ }^{486}$. Este argumento é combatido pela referência ao artigo 25 do Estatuto do Tribunal Penal Internacional, que prevê a responsabilidade individual ${ }^{487}$ das pessoas físicas, conforme entendimento esposado por autores como CARILLO SALCEDO e BASSIOUNI ${ }^{488}$.

\footnotetext{
${ }^{485}$ V. o Ditame de 28/05/1951 sobre as reservas à Convenção sobre o Genocídio, em relação ao caráter de ius cogens das normas a seu respeito, afirmando que "os princípios que subjazem à Convenção são princípios que são reconhecidos pelas nações civilizadas como vinculantes para os Estados, inclusive fora de qualquer obrigação convencional (...). Nesta Convenção, os Estados Partes não tem interesses próprios; simplesmente tem, todos e cada um, um interesse comum, ou seja, o cumprimento dos elevados fins que são a razão de ser da Convenção". V. KELSEN, Hans, "Collective and Individual Responsibility in International Law with Particular Regard to the Punishment of War Criminals", in California Law Review, 1942-43.

${ }^{486}$ Conforme os arts. 49, art. 50, II, art. 129, III, art. 146, IV da Convenção de Genebra I, Protocolo Adicional I, art. 85.

487 "Any person who commits and act which constitutes a crime under international law is responsible therefore and liable to punishment", conforme já previa o International Law Commission: Report on the Principles of Nuremberg Tribunal, Princípio I, A/1316, 1950. Nações Unidas, Assembleia Geral.

${ }^{488}$ CARRILLO SALCEDO, J.A. Soberanía de los Estados y Derechos Humanos en Derecho Internacional contemporâneo. Tecnos: Madri, 1995; BASSIOUNI, Cherif M. "El derecho penal internacional: historia, objeto y contenido". ADPCP, Oceana Publications, Nova Iorque, 1982.
} 
Como modernamente já se tem admitido o indivíduo como sujeito de direitos na órbita internacional, nos termos do direito internacional moderno, sobretudo pela influência dos direitos humanos, tem-se reconhecido a responsabilidade penal direta do indivíduo, conforme JESCHECK, ao referir-se à própria redação da Convenção contra o Genocídio de 1948, na qual se declara o genocídio crime de direito internacional (under international Law) e não meramente crime contra o direito internacional (against international Law) ${ }^{489}$.

Para a validação de um direito penal máximo, que se flexibiliza diante de um mal absoluto e que atenta contra a existência humana, devemos estar diante de uma teoria consolidada com relação ao seu objeto de proteção e critérios que conferem validade à norma. GIL GIL destaca três fases do direito penal internacional: a) uma primeira quando se produz uma valoração positiva de determinados bens jurídicos, expressos em algumas declarações internacionais (Carta das Nações Unidas, Declaração de direitos humanos); b) uma segunda quando se valoram negativamente as condutas que lesionam ou colocam em perigo estes bens, proibindo-se a realização de certas condutas; c) um terceiro momento, em que se reconhece a responsabilidade individual no âmbito internacional, impondo-se pelo direito internacional penal uma consequência jurídica, uma pena, à infração praticada da norma, a partir de quando se pode falar da existência de uma lei penal internacional.

Braço inescapável para a construção da terceira fase, a existência do Tribunal Penal Internacional faz com que o direito penal internacional seja cada vez mais uma realidade na construção de uma jurisdição universal. Para BASSIOUNI ${ }^{490}$, o conteúdo do direito penal internacional poderia extrair-se a partir da regulação internacional de temas como o controle da guerra, a regulamentação dos conflitos armados, a persecução das leis de guerra, crimes comuns de interesse internacional.

\section{d) Jurisdição Universal}

\footnotetext{
489 JESCHECK, H.H. "Nuremberg Trials". In: BERNHARD, R. (ed). Encyclopedia of Public International Law, Inst. 4, 1982, p. 542, citado por GIL GIL, op. cit., 1999, p. 5.

${ }^{490}$ BASSIOUNI, M, Cherif. "El derecho penal internacional: historia, objeto y contenido". ADPCP Oceana Publications, Nova Iorque, 1982, p. 9.
} 
No primeiro capítulo abordamos a questão da construção de uma comunidade ética mundial que se organiza para gerir os problemas da sociedade contemporânea com categorias e recursos do direito penal, desde a sociedade do risco, até os reflexos da globalização, com base no entendimento de que não existem soluções locais para problemas globais $^{491}$. Com mais dificuldades, mas não com menos impacto, foi o processo de construção das instituições e do conceito de jurisdição universal.

Grócio defendia o princípio da repressão universal a crimes graves, com base no direito natural, ideia que foi oposta por Montesquieu, Voltaire, Rousseau e, principalmente, BECCARIA, preferindo o princípio da territorialidade da lei penal, consagrada, inclusive, pela Revolução Francesa ${ }^{492}$. Para CASSESE, as razões de BECCARIA, sob o argumento de que com a variação das leis de país para país, só se poderia exigir sua obediência no território em que essa fora infligida, que também é o local onde o pacto social fora rompido, seriam aceitáveis no século XVIII. Hoje vigora uma lei universal na comunidade internacional que pune os crimes internacionais, normas de jus cogens, a proibirem crimes de guerra, crimes contra a humanidade, genocídio, tortura e graves manifestações de terrorismo internacional, numa conceituação já antevista por BECCARIA em 1764, quando ele concluía que, ainda assim, os juízes não deveriam atuar como vingadores da sensibilidade humana em geral, mas das convenções que ligam os homens entre $\mathrm{si}^{493}$.

A jurisdição universal pode ser absoluta ou relativa, sendo exemplo do primeiro caso as leis da Espanha ${ }^{494}$ e da Bélgica ${ }^{495}$, mas também, em último grau, os princípios

\footnotetext{
${ }^{491}$ SINGER, Peter, Un solo mundo. La ética de la globalización, 2002, Paidós: Barcelona.

${ }^{492} \mathrm{~V}$. decreto 3, 7.9.1792, "os estrangeiros acusados de delitos em sua pátria só pode ser julgados conforme as leis de seu país e por seus magistrados", citado por CASSESE. CASSESE, DELMAS-MARTY, Crimes Internacionais(...), op. cit., 2004, p. 12.

${ }^{493}$ BECCARIA, op. cit., nota 474.

${ }^{494}$ V. art. 23, 4.(a); (b); e (g), segundo o qual os tribunais espanhóis são competentes para se pronunciar sobre crimes cometidos no exterior ou espanhóis ou estrangeiros em casos de genocídio, terrorismo e outros crimes previstos em tratados internacionais ratificados pela Espanha e que prevejam essa competência. Nesses termos, "igualmente será competente la jurisdicción española para conocer de los hechos cometidos por españoles o extranjeros fuera del territorio nacional susceptibles de tipificarse, según la ley penal española, como alguno de los siguientes delitos: (a) Genocidio; (b) Terrorismo (...); ( $g$ ) Y cualquiera otro que, según los tratados o convenios internacionales, deba ser perseguido en España".

${ }^{495}$ V. lei de 16.06.1993, alterada pela lei de 10.02.1999, sobre a repressão às infrações graves à Convenções Internacionais de Genebra de 1949 e os dois protocolos adicionais, prevendo-se no art. 7": "Les juridictions belges sont compétentes pour connaître des infractions prévues à la présente loi, indépendamment du lieu ou celles-ci auront été commises. Pour les infractions commises à l'étranger par un belge contre un étranger, la plainte de l'étranger ou de sa famille ou l'avis officiel de l'autorité du pays ou l'infraction a été commise n'est pas requis."
} 
incluídos no The Princeton Principles on Universal Jurisdiction, de 2001, códex elaborado por eminentes juristas anglo-saxões. De acordo com ele, a jurisdição universal decorre unicamente do tipo de crime cometido, independente do lugar ou de quem o tenha perpetrado, de sua vítima ou da jurisdição do Estado em questão, exercido por qualquer corte nacional ${ }^{496}$.

Sem dúvida que a perspectiva da jurisdição universal debita pressupostos caros à soberania nacional e o dever de prestação jurisdicional que o Estado deve garantir aos seus cidadãos. A simplicidade com que previstos em tratados internacionais, como os crimes contra a humanidade, a possibilidade de existência de múltiplos processos contra os mesmos réus e de muitos critérios a se considerar a prevalência de uma jurisdição sobre outra ${ }^{497}$ ou uma interpretação do que seria um julgamento "de acordo com as normas e padrões internacionais" ${ }^{\prime 498}$, pode favorecer a fragmentação do direito penal ao se considerar que os juízes não seriam juízes do direito local, mas incumbidos de agir como "órgãos da comunidade internacional, como guardiões dos valores fundamentais dessa comunidade".

\footnotetext{
${ }^{496}$ Nesse sentido, textualmente, "1.For purposes of these Principles, universal jurisdiction is criminal jurisdiction based solely on the nature of the crime, without regard to where the crime was committed, the nationality of the alleged or convicted perpetrator, the nationality of the victim, or any other connection to the state exercising such jurisdiction. 2. Universal jurisdiction may be exercised by a competent and ordinary judicial body of any state in order to try a person duly accused of committing serious crimes under international law as specified in Principle 2(1), provided the person is present before such judicial body." (disponível em http://www1.umn.edu/humanrts/instree/princeton.html, Acesso em 12.05.2015)

${ }^{497}$ Para isso, os Princeton Principles adotam uma ponderação dos vários critérios, conforme: Principle 8 -Resolution of Competing National Jurisdictions. Where more than one state has or may assert jurisdiction over a person and where the state that has custody of the person has no basis for jurisdiction other than the principle of universality, that state or its judicial organs shall, in deciding whether to prosecute or extradite, base their decision on an aggregate balance of the following criteria: (a) multilateral or bilateral treaty obligations; $(b)$ the place of commission of the crime; (c) the nationality connection of the alleged perpetrator to the requesting state; (d) the nationality connection of the victim to the requesting state; $(e)$ any other connection between the requesting state and the alleged perpetrator, the crime, or the victim; (f) the likelihood, good faith, and effectiveness of the prosecution in the requesting state; $(g)$ the fairness and impartiality of the proceedings in the requesting state; $(h)$ convenience to the parties and witnesses, as well as the availability of evidence in the requesting state; and (i) the interests of justice. Grifo nosso. Nota-se que ainda que se fale em um balanço dos critérios, preferiu-se elencar em primeiro lugar as obrigações fixadas em tratados ao elemento de ligação relacionado ao local de perpetração do crime.
}

${ }^{498}$ V. estudo produzido pela REDRESS, "La Compétence Extraterritoriale dans l'Union Européenne - Étude des Lois et des Pratiques dans les 27 États Membres de l’Union Européenne”, dez. 2010, (disponível em http://www.redress.org/downloads/publications/Extraterritorial Jurisdiction_In_the27_Member_States_of_ the_EU_FR.pdf. Acesso 20.6. 2013). 
Os crimes contra o direito internacional, segundo JESCHECK ${ }^{499}$, definem-se pelas seguintes características: a existência de uma norma penal que decorre de um tratado ou costume internacional vinculando a maioria dos Estados e diretamente aplicável aos indivíduos sem necessidade de intervenção da lei nacional e o fato de poder ser processado por qualquer tribunal internacional ou tribunais nacionais atuando com base no princípio da jurisdição universal. A construção do direito penal aliado ao direito internacional adotou todo o arcabouço do direito internacional sendo do escopo penal apenas o objetivo sancionador do direito que se quer aplicar.

Por se tratar dos crimes centrais do direito penal internacional, há quem os chame de "core crimes" $" 500$, decorrentes do Estatuto do TPI e das Regras de Procedimentos e Provas, que distingue estes crimes dos demais, com base nas a) características qualitativas gerais, que os diferencia dos demais crimes transnacionais ou previstos nos tratados; b) a inclusão de elementos contextuais de cada tipo criminal, também distinguindo-os dos crimes transnacionais e nacionais; c) o princípio da complementaridade em combinação com provisões de certos critérios de admissibilidade dos casos, a determinar quais crimes podem se processar no âmbito do TPI.

O critério qualitativo, como afirmado, corresponde aos crimes mais graves, conforme previsto no preâmbulo do Estatuto do TPI (ETPI), §§ $2^{\circ}$ e $3^{\circ}$, referindo-se às "atrocidades inimagináveis que profundamente chocam a consciência da humanidade", cuja repercussão leve a "ameaça à paz, segurança e bem-estar do mundo". Ainda, os $\S \S 4^{\circ}$ e $9^{\circ}$ do preâmbulo tratam dos "crimes da maior gravidade que afetam a comunidade internacional", criando uma categorização do crime que poderia ser uma qualificadora de outros crimes definidas pelo tipo, mas que na situação presente é o elemento fundamental do tipo. Faz parte, ainda, da punição dos crimes, o objetivo de "pôr fim à impunidade" e “contribuir para a prevenção de tais crimes" $\left(\S 5^{\circ}\right)$, e afirmando a pertinência deste diploma no universo de respeito aos direitos humanos, faz referência aos "Objetivos e Princípios consignados na Carta das Nações Unidas” $\left(\S 7^{\circ}\right)$. Esses elementos qualitativos, portanto, auxiliam a definição da admissibilidade, conforme a definição de competência firmada no

\footnotetext{
499 JESCHECK, H.H. Op. cit., pp. 1119 ss.

${ }^{500}$ Conforme CHOULIARAS, Athanasios. "Bridging the gap between criminological theory and penal theory within the international criminal justice system". European Journal of Crime, Criminal Law and Criminal Justice 22, 2014, p. 267.
} 
art. $5^{\circ}$ do ETPI, ou seja, "restringir-se-á aos crimes mais graves, que afetam a comunidade internacional no seu conjunto".

Colateral à questão da qualidade dos crimes, também é necessária a presença de elementos contextuais para configurar a dimensão nas quais os crimes são perpetrados. Assim, tanto pode fazer referência à dimensão territorial (envolvimento de pelo menos grande parte de uma população), o contexto político (um contexto organizacional amplo), e, no caso de genocídio, "com intenção de destruir, no todo ou em parte, um grupo nacional, étnico, racial ou religioso", ou no caso dos crimes contra a humanidade, "cometido no quadro de um ataque, generalizado ou sistemático, contra qualquer população civil, havendo conhecimento desse ataque" (arts. 6 e 7.1 do ETPI, respectivamente). Os Elementos dos Crimes também descrevem a forma como deverá ocorrer o crime para determinar a competência do TPI, e, no caso de genocídio, afirma que "a conduta ocorre no contexto de um manifesto padrão de condutas similares, direcionada contra o grupo ou a conduta ocorreu de tal forma que por si teria causado tal destruição"501.

Se, por um lado, a obrigação de julgar e punir os crimes contra o direito internacional, permanece como prerrogativa dos países que viveram os referidos crimes $\left(\S 6^{\circ}\right.$ do preâmbulo), o TPI poderá exercer essa competência de maneira complementar à jurisdição nacional, como previsto no $\S 10^{\circ}$ do preâmbulo e repetida no art. $1^{\circ}$ do Estatuto, nos casos em que o Estado "não tiver vontade de levar a cabo o inquérito ou o procedimento ou, não tenha capacidade para o fazer" (art. 17.1, do ETPI). Há que se levar em conta que estamos diante de um estado incipiente de desenvolvimento do sistema legal internacional, fazendo com que em diversos casos se recorra a órgãos internos para sua aplicação ${ }^{502}$, com leituras nacionais dos crimes sob consideração, existência das cortes ad hoc, entre outros problemas de aplicabilidade das normas de direito penal internacional e processual penal internacional.

Pode-se afirmar que a existência do conceito de justiça universal concretiza o direito ao acesso à justiça, embora há que se verificar de que forma o direito violado teria titulação em âmbito internacional. Se o acesso à justiça é um conceito apegado à capacidade

\footnotetext{
${ }^{501}$ Item 6.d, § 5, do Elements of Crimes (trad. livre).

502 Cf. GIL GIL, Derecho Penal Internacional, op. cit., 1999, pp. 58 ss.
} 
de o Estado instrumentalizar e prover de forma central a justiça num território, sua transposição para o âmbito internacional é lacunosa, pelos próprios pressupostos teóricos em que instituído o sistema normativo internacional - descentralizado e aberto ${ }^{503} \mathrm{e}$, a respeito da soberania, pela não existência de um sistema baseado em regras superiores acima da vontade dos governantes e dos Estados-Nação que o constituíram ${ }^{504}$. MENEZES indica o compartilhamento em nível internacional de valores de civilidade para a noção, ainda que em iniciativas tímidas, de distribuição de justiça na sociedade internacional, aliado ao fato da incorporação do indivíduo na pauta do direito internacional, sendo, para o autor, a garantia do acesso à justiça respaldada no plano internacional por meio de Tribunais Internacionais e de Acordos, uma "exigência natural da organização da vida social" ${ }^{505}$. Para MENEZES, o conceito de acesso à justiça no plano internacional está vinculado, portanto: “a) ao conjunto de direitos tutelados no plano internacional; b) à definição dos sujeitos titulares das normas internacionais; c) aos mecanismos jurídicos disponíveis e acessíveis para invocação dos direitos lesados ou pretensamente tutelados; d) à efetividade com base no princípio da boafé, das decisões judiciais oriundas dos tribunais internacionais.” Da mesma forma, portanto, a justiça criminal internacional não é concebida de maneira estável e hierarquizada, mas de uma ordem interativa e evolutiva, nas palavras de DELMAS-MARTY e CASSESE ${ }^{506}$, indicando que estamos em um momento num processo ainda em largo curso.

É certo que a construção da jurisdição internacional passa pelo questionamento da soberania nacional em primeiro plano, pois se está falando, em verdade, de um direito penal internacional superior às leis nacionais, o desaparecimento da condição de nacional de um país, o surgimento de uma capacidade de sanção e eventual execução das penas por autoridades internacionais ${ }^{507}$. No entanto os Estados continuarão sendo os principais atores na órbita internacional e, em geral, de tudo que afeta a vida dos cidadãos com respeito ao

\footnotetext{
${ }^{503}$ Nesse sentido, MENEZES, Wagner, Tribunais Internacionais - Jurisdição e Competência, Ed. Saraiva: São Paulo, 2013, p. 33 ss.

${ }^{504}$ FERRAJOLI, Luigi. A soberania no mundo moderno. São Paulo: Martins Fontes, 2002, conforme citado por MENEZES, Wagner, Tribunais internacionais (...), op. cit., p. 50.

${ }^{505}$ MENEZES, Wagner. Tribunais internacionais (...), op. cit., 2013, p. 37.

506 DELMAS-MARTY, Mireille; CASSESE, Antonio. Crimes internacionais e jurisdições internacionais. Barueri: Ed. Manole, 2004.

507 Para maior aprofundamento, v. BADIE, B., Um monde sans souveraineté, les Étas entre ruse et responsabilité, Fayard, 1999. Também HENZELIN, M., Le principe de l'université en droit penal internacional, Bruxelas: Bruylant, 2000, PRADELLE, G. de la, "La competence universelle". In: ASCENSIO, H. DECAUX E. e PELLET, A. (ed.), Droit Internacional Pénal, Paris: Pedone, 2000; BASSIOUNI, M.Cherif, "Universal jurisdiction for International Crimes: Historical Perspectives and Contemporary Practice", 42, Virginia Journal of International Law, 2001.
} 
uso da força ${ }^{508}$. SAAD-DINIZ ${ }^{509}$ faz referência à busca do controle internacional dos julgamentos ocorridos no Brasil para a revisão da Lei de Anistia, conforme tratado no capítulo $2^{\circ}$, pois se trata da ideia de construção de um controle exercido fora do Estado em torno do princípio da justiça universal.

Os TPIs não dispõem de força executiva, de polícia judiciária, o que limita seu poder de fato, pois a execução de todos os atos, desde convocação de testemunhas, busca e apreensões, mandados de intimação ou ordens de prisão, sempre depende a cooperação das autoridades nacionais. Assim, para a execução de medidas expedidas pelos TPIs e que dependam da ação dos Estados soberanos não há medida do TPI contra estes últimos, como os casos de não entrega de cidadãos nacionais para julgamento pelas cortes internacionais, bem como a revisão de leis nacionais contrárias às normas internacionais - caso os Estados se recusem a dar efeito à revisão decidida pelos tribunais internacionais, não existem meios coercitivos de fazerem valer suas decisões. Também em relação à jurisdição internacional, trata-se de uma construção frágil diante das possibilidade técnicas do exercício da jurisdição nacional, podendo o Estado escolher se adere ou não ao princípio, "relativizando a integração do comportamento decisório nos âmbitos nacional e supra-nacional"510.

Por fim, com vistas a possibilitar o julgamento em concreto de agentes estatais por jurisdições internacionais sem que estes possam escudar-se na soberania, com valor ao ditado de que par in parem non habet juriscictionem, há que se estabelecer a exclusão da teoria do ato de soberania, com a afirmação da jurisdição universal.

Na conformação e combinação de princípios e modelo para a aplicação da lei penal no espaço, o que era a antiga forma do direito penal internacional, FIGUEIREDO DIAS trata do princípio-base e dos princípios acessórios ou complementares. Como princípio base, considera-se o da territorialidade, sendo acessórios o da nacionalidade, o da

\footnotetext{
${ }^{508}$ Em matéria ligada ao direito penal internacional, CASSESE lembra disposições internas de constituições de países de tradição romano-germânica, em que se protegia ao máximo os nacionais contra qualquer ingerência estrangeira - "expressão típica da comunidade internacional de Westfália, uma comunidade de Estados soberanos que desconfia um dos outros, desprovidos de valores universais comuns" (2012, p. 5). São citadas as Constituições do Brasil (art. 50), República Federal Alemã (de 1949, art. 16, "2"), da Polônia (de 1997, art. 55, "1", da Eslovênia (de 1991, art. 47), da República Federal da Iugoslávia (de 1992, art. 17, “3”), entre outras. ${ }^{509}$ SAAD-DINIZ, Eduardo. "El enclave de los juicios de transición: observación del caso brasileño". Revista de derecho penal y procesal penal, 12, 2011, p. 2082.

${ }^{510}$ SAAD-DINIZ, Eduardo. "El enclave de los juicios de transición: observación del caso brasileño". Revista de derecho penal y procesal penal, 12, 2011, p. 2082.
} 
defesa dos interesses nacionais e, o que nos interessa especificamente, o da aplicação universal ou da universalidade, que determina que o Estado persiga os fatos contra os quais "se deva lutar a nível mundial ou que internacionalmente ele tenha assumido a obrigação de punir, com indiferença pelo lugar da comissão, pela nacionalidade do agente ou pela pessoa da vítima" $" 511$.

Acrescenta o autor, a este respeito, que:

\begin{abstract}
"Este princípio assume cada vez maior importância no mundo actual, não só devido à crescente preocupação internacional com certo tipo de infracções (crimes de genocídio, violações graves do direito humanitário, terrorismo, etc.) - que, paralelamente, deram lugar à criação de jurisdições internacionais para o conhecimento desses crimes (...) - como também por força do caráter global de certos riscos dotados de potencial lesivo transnacional em matéria de ambiente, manipulação genética, criminalidade altamente organizada" (2007, p. 208).
\end{abstract}

Dentro a análise do princípio da universalidade, sobre o qual se debruça o direito penal internacional, FIGUEIREDO DIAS reconhece a existência do caráter supranacional de certos bens jurídicos, voltados à proteção no plano mundial. Conforme JESCHECK, o princípio do direito mundial só encontra justificativa quando o delito atente contra bens culturais supranacionais de cuja proteção exista um interesse comum de todos os Estados. Nestes específicos casos, trata-se da consagração de uma "solidariedade do mundo cultural em face do delito" e da "luta contra a delinquência internacional perigosa"512. Por outro lado, não se pode considerar o direito penal internacional como aquele que sanciona as violações ao direito internacional pois não se pode atribuir a este ramo do direito a tutela da totalidade da ordem internacional, mas que somente se recorre a ele quando, nas palavras de GIL GIL, "sea absolutamente imprescindible por resultar insuficientes otras formas de reacción jurídica, es decir, también en el ámbito del derecho penal internacional es necesario defender el carácter de ultima ratio del derecho penal en la defensa del orden social" ${ }^{\prime 513}$.

${ }^{511}$ FIGUEIREDO DIAS, Jorge de. Direito Penal - Parte Geral, op. cit., 2007, p. 208.

512 JESCHECK, H.H., "Nuremberg Trials", op. cit., p. 153.

${ }^{513}$ Sobre o caráter de ultima ratio, v. Cerezo Mir, J. Curso de derecho penal español, op. cit., pp 59-60, REALE JR, Miguel, Teoria do Delito, 1998, p. 39-45, e GIL GIL, Derecho Penal Internacional, op. cit., 1999 , p. 29. 


\subsection{O direito penal internacional e a teoria do bem jurídico}

\subsubsection{Aspectos Gerais do Bem Jurídico em DPI}

$\mathrm{O}$ direito penal internacional volta-se à apuração de responsabilidades atinentes às condutas ilícitas praticadas por indivíduos, com repercussão na esfera internacional. Os crimes objeto de sua abrangência não são aqueles praticados por Estados, como no direito internacional público clássico, mas atribuíveis a indivíduos e que atinja "a paz, a segurança e o bem estar da humanidade", conforme o preâmbulo do Estatuto do TPI, $\S 3^{\text {o514 }}$. WERLE afirma que o ataque a estes bens dá a dimensão internacional e converte o fato em um crime de direito internacional ${ }^{515}$, ao afetar a "comunidade internacional em seu conjunto", nos mesmos termos do preâmbulo, $\S \S 4^{\circ}$ e $9^{\circ}$, e art. 51 do Estatuto do TPI.

Concondamos com GIL GIL, para quem a definição do direito penal internacional passa pela análise de sua função, que como em direito penal interno, é à proteção de bens jurídicos vitais, mais importantes da sociedade internacional, frente a formas mais graves de agressão, mantendo-se, portanto, seu caráter fragmentário, subsidiário e de ultima ratio, ou seja, não visa a proteção de toda a ordem jurídica internacional, mas apenas de seu núcleo essencial. Nessa seara, não faz parte do objeto de estudo em questão temas de direito penal interno, aplicado extraterritorialmente, sobretudo porque a projeção internacional do direito interno retira a essência do direito penal internacional: a construção de uma ordem nova (supranacional), em torno a um bem novo (paz internacional e dignidade humana, em inter-relação), com instrumentos jurídicos novos (resoluções ou tratados constitutivos de tribunais internacionais) em exercício de um poder novo (jurisdição

\footnotetext{
${ }^{514}$ Sobre o valor jurídico do preâmbulo, remetemos à discussão no âmbito do direito constitucional, dentro da teoria do bloco de constitucionalidade, fortalecida a partir da decisão sobre a liberdade de associação do Conselho Constitucional Francês em 16 de julho de 1971. A este respeito, Louis FAVOREAU e Loïc PHILIP consideraram a consagração do valor jurídico do preâmbulo, alargando a noção de conformidade à Constituição, aplicando os princípios fundamentais reconhecidos pelas leis. FAVOREAU, Louis; PHILIP, Loïc. Le Conseil Constitutionnel, Paris: PUF, 1985, p. 4. Em direito internacional, por outro lado, nos termos do art. 31 da Convenção de Viena sobre o direito dos tratados, para os fins de interpretação de um tratado, faz parte da regra de interpretação a referência ao contexto, que " compreenderá, além do texto, seu preâmbulo e anexos" (promulgada pelo Decreto n. ${ }^{\circ} 7.030$, de 14 de dezembro de 2009).

${ }^{515}$ Cf. WERLE, Gerhard. Tratado de DPI, op. cit., p. 80.
} 
internacional). PELLA considera a paz internacional como o bem jurídico supremo contra o qual atenta direta ou indiretamente os crimes contra a paz, os crimes contra a humanidade $\mathrm{e}$ os crimes de guerra, considerando esta infração como "uma ação ou omissão internacionalmente perigosa que tenha contribuído à preparação ou execução de uma guerra proibida ou a violação das leis e costumes de guerra, ou a criação de situações capazes de perturbar as relações pacíficas entre os Estados, ou uma política nacional que ofenda a universalidade do sentimento humano" ${ }^{\circ 16}$.

Consoante a doutrina moderna, a teoria do bem jurídico vem sendo construída levando em conta os princípios da lesividade e da intervenção mínima para a precisa conformação do Estado Democrático de Direito. A evolução da teoria, no entanto, tem sofrido abalos em função da presença cada vez mais comum de crimes nos quais o bem jurídico ou é de difícil apreensão ou é inexistente. A acomodação desta reorientação em relação à captação do bem jurídico é o desafio à teoria que dá substrato ao direito penal internacional. Essa preocupação encontra-se intimamente ligada em se saber quando, quanto e como usamos o Direito Penal no plano internacional.

A problemática incidente nesta discussão passa mais uma vez pela informalidade típica da norma costumeira, embora não se possa dizer que ela é desconhecida ou que conflite com outras normas internacionais se tomamos como bem jurídico tutelado a existência de sociedades que compõem a humanidade. Assim, tanto a abstração própria do bem jurídico tutelado quanto as características de afirmação da norma costumeira fragilizam sua conformação teórica. Por outro lado, o conteúdo histórico do bem jurídico também permite que novas formas de violação sejam acrescidas em virtude das transformações sociais e históricas da sociedade mundial, podendo chegar ao que TRIFFTERER ${ }^{517}$ sugeriu de normas obrigatórias regionalmente consideradas que aderissem a ela. Neste ponto, assumir-se-ia a relatividade dos bens jurídicos em questão, o que não parece ser a melhor orientação para a proteção dos valores subjacentes à proteção contra os crimes contra a humanidade, ou bens jurídicos totais.

\footnotetext{
516 PELLA, Vespasian. La Guerre-Crime et les Criminels de Guerre, Paris, 1946, p. 49.

517 TRIFFTERER, O. "Völkerstrafrecht im Wandel?", in Fertschrift für Hans-Heinrich Jescheck zum 70 Geburtstag, t. II, 1985, p. 1502, apud GIL GIL, 1999, p. 52.
} 
Assim, o conceito, tal como originalmente concebido por BIRNBAUM vem sofrendo paulatinos ajustes, ponderações, aclimatações e não poderia sair ileso da prova de fogo para servir como base, denominador comum, para todos os crimes existentes ao longo dos séculos. O bem jurídico seria o núcleo a partir do qual todo o sistema penal ter-se-ia erigido, como uma construção dogmática capaz de exercer uma função crítica limitadora do direito de punir do Estado ao mesmo tempo em que funciona como um referencial material do delito.

O desencantamento com a teoria do bem jurídico, entretanto, decorre muito mais da incapacidade do exercício da função limitadora do que da falta de identificação referencial material do delito, visto a avalanche de novos tipos e novos bens jurídicos penais, novas acomodações que a teoria faz para se manter como elemento chave na apreensão do fenômeno punitivo da sociedade. A nova categoria de criminalidade, internacional, que afronta os limites da soberania (macrocriminalidade), passa a exigir uma nova lógica e, portanto, nova acomodação da teoria do bem jurídico penal, desta vez sob a ótica de um bem jurídico novo: não individual, não social, não difuso ${ }^{518}$, mas um pouco de todos e de uma nova categoria, universal. Entretanto, essa função crítica, abordada por STERNBERGLIEBEN $^{519}$, não pode ser prescindida pelo direito penal sob pena de se tornar completamente vulnerável ao arbítrio autoritário, sem o mínimo valorativo do injusto, que permite a confrontação da dogmática com a valorativa.

Ao adentrarmos na área do direito penal internacional, deixa-se de estar sob o monopólio da legislação e da jurisdição dos Estados, especialmente pela aceitação da jurisdição do Tribunal Penal Internacional, a adaptação de legislações internas ao seu Estatuto, como no caso de Portugal pela Lei 31/2004, a tipificação dos crimes de violação do direito internacional dos direitos humanos e também do Brasil, por meio do Decreto $\mathrm{n}^{\mathrm{o}}$ 4.388/2002 e do Projeto de Lei no 4038/2008, em tramitação no Congresso Brasileiro.

\footnotetext{
${ }^{518}$ Nesse sentido, v. SILVEIRA, Renato M. J.: "Na realidade, parece claro que enquanto os bens jurídicos individuais e coletivos satisfaziam-se com uma proteção bastante atinente ao eventual efeito danoso, tendo por exceção o perigo potencial de dano, no que se refere aos bens difusos ou supra-individuais isso não se verifica. Meio ambiente, Direito Econômico ou do Consumidor, por exemplo, guardam peculiaridades próprias (2003, p. 14).

${ }^{519}$ STERNBERG-LIEBEN, Detlev. "Bien jurídico, proporcionalidad y libertad del legislador penal”. In: Hefendehl, Roland. La teoria del bien jurídico: ¿Fundamento de legitimación del derecho penal o juego de abalorios dogmático? Madrid: Marcial Pons,2007
} 
Em vista das próprias características das fontes de direito penal internacional serem imprecisas, parece inevitável que essas qualidades sejam transportadas ao bem jurídico de seus crimes, numa contaminação cruzada que debilita num sentido a capacidade da teoria do bem jurídico de indicar os limites para a criminalização pelo direito penal internacional, e de outro, autorizar equivocadamente a criminalização de violações de direitos humanos em geral.

\subsubsection{Direitos Humanos não são bens jurídicos penais}

A partir do final da II Guerra Mundial o mundo conhece o desenvolvimento de uma rede de instituições internacionais e supranacionais que, sem ser especificamente penal, "confirma e cobre em muitos pontos o direito penal nacional impondo-lhe suas próprias regras. Essa rede cria uma nova tensão entre o limite imposto pelos Estados (talvez também os limites infranacionais) - e o direito de punir aceito como mal necessário - e a exigência, sempre premente, de um respeito mais efetivo às liberdades e aos direitos humanos pensados como bem ideal" ${ }^{, 20}$. As normas juntamente com as instituições conformam uma nova perspectiva nas relações internacionais, prevendo crimes e processamento criminal sem penas, aplicação de penas pelas cortes internacionais muitas vezes proibidas pelas legislações nacionais dos Estados que compõem o tratado que cria o tribunal. A heterogeneidade do espaço, conforme DELMAS-MARTY, implica algo diferente do que o aparecimento de novos loci institucionais: ela provoca a abertura do campo penal.

Embora haja uma tendência de se identificar a abertura do campo penal com a tendência de proteção dos direitos humanos em escala planetária, seria um equívoco proteger um pelo outro, os direitos humanos pelo direito penal, pelas próprias origens e racionalidade que informam cada um deles. Embora a tendência expansiva do direito penal passe pela internacionalização de seus mecanismos de atuação e, nesse sentido, pela sua integração com os pressupostos do direito penal internacional, o conceito multiforme de direitos humanos ${ }^{521}$

\footnotetext{
${ }^{520}$ DELMAS-MARTY, Mireille. A imprecisão do direito - do código penal aos direitos humanos. Trad. Denise Radanovic Vieira. Ed. Manole: Barueri, 2005, p. 89.

${ }^{521}$ Uma vasta literatura, nas mais diferentes áreas do conhecimento (filosófica, política, jurídica, cultural), é produzida nesse sentido. De forma abrangente, ALEXANDRINO, José Melo. “A natureza variável dos direitos humanos: uma perspectiva da dogmática jurídica". In: HOMEM, Antonio Pedro Barbas; BRANDÃO, Cláudio. Do direito natural aos direitos humanos. Coimbra: Almedida, 2014, pp. 25 ss
} 
não confere concreção à preocupação, ainda que nem sempre bem-sucedida, de se limitar o escopo de intervenção da norma penal. Ainda que se diga que os direitos humanos traduzem a realidade jurídica das aspirações para a proteção da dignidade humana, é inescapável seu caráter de tropo retórico: o que era um atributo da pessoa passou a ser manuseado como substância e, servindo para tudo, também passou para servir ao seu contrário ${ }^{522}$. Se existe mesmo a tendência, como afirmado por ASCENSÃO ${ }^{523}$, de se substituir conceitos precisos por locuções esvaziadas, revela-se inadequado que ela sirva para limitar o conteúdo repressivo da norma penal. E, detendo feições universais, SILVEIRA ${ }^{524}$ identifica a incompreensão da alternância de soluções em relação a situações semelhantes por cortes de direitos humanos.

Ainda que se considere que a persecução penal mesmo em sede de crimes internacionais deva ser compreendida como ultima ratio para proteção de bens jurídicos, justificada pelo impacto internacional causado por certas violações à segurança coletiva da comunidade mundial ou da humanidade, deve-se buscar distinguir bens jurídicos de direitos humanos. A ordem internacional possui a especial característica de ter à frente o protagonismo dos Estados como principais sujeitos de direito internacional, organizados sob o interesse geral prevalente da comunidade internacional. Portanto, a ordem internacional seria uma espécie de supraordenação dos interesses coletivos, titularizados pelo EstadoNação, visto que este, em última instancia, é um instrumento a serviço do indivíduo e da sociedade, uma forma de organização racional para garantir os bens jurídicos ${ }^{525}$.

522 ASCENSÃO, Oliveira, em relação a questões de proteções a liberdades sexuais e punibilidade. ASCENSÃO, José de Oliveira. "O "fundamento do direito": entre o direito natural e a dignidade da pessoa. In: HOMEM, Antonio Pedro Barbas; BRANDÃO, Cláudio. Do direito natural aos direitos humanos. Coimbra: Almedida, 2014, pp. 25 ss.

523 ASCENSÃO, José de Oliveira. "A dignidade da pessoa e o fundamento dos Direitos Humanos. In: MIRANDA, Jorge. Estudos em homenagem ao Prof. Doutor Martin de Albuquerque, vol II, Fac. de Direito da Univ. de Lisboa, Coimbra Editora, 2010, pp. 37-58.

${ }^{524}$ SILVEIRA, Renato de Mello Jorge da. "Labirinto penal e o caso brasileiro: a tensão entre o sistema nacional e o sistema internacional na tutela dos direitos humanos". In: HOMEM, Antonio Pedro Barbas; BRANDÃO, Cláudio. Do direito natural aos direitos humanos. Coimbra: Almedida, 2014, pp. 387 ss. Nesse trabalho, o autor discute a assimetria das decisões sobre direitos humanos com base em decisões nacionais, da CorteIDH e da Corte Europeia de Direitos Humanos envolvendo assuntos como a lei de anistia, a ficção em torno da continuidade criminosa do desaparecimento forçado, dentro da perspectiva do labirinto penal.

525 Para MUÑOZ CONDE, "el Estado no es más que la superestrutura de un determinado tipo de sociedad incapaz por si misma de organizar la convivencia de un modo determinado y pacifico" pero "de la existencia del Estado se deriva una serie de intereses que el mismo Estado protege, incluso más fuertemente que otros valores comunitarios y personales, amenazados con pena su lesión o puesta en peligro". Derecho penal, Parte Especial, 11 ${ }^{a}$ Ed., Valência: Tirant lo Blanch,, 1996, p. 647. V. também, GIL GIL, Alicia. El derecho penal internacional, op. cit., 1999, p. 33. 
De outra parte, o fato de paz e segurança da humanidade estarem consagrados na Carta das Nações Unidas como fins a serem perseguidos pela comunidade internacional não transforma esses valores em bens jurídicos concretos protegidos pelos tipos dos delitos internacionais, ainda que representem em máxima envergadura o objeto jurídico genérico da ordem penal internacional. Pela maior precisão do conteúdo criminal em relação aos direitos humanos, não podemos transpassar um conceito de um lado a outro indiscriminadamente. Necessário, assim, abordar o tema dos bens jurídicos coletivos para trabalharmos com os conceitos relevantes ao presente trabalho.

A origem do direito penal internacional coincide com o próprio desenvolvimento do conceito de crime contra a humanidade, quando se criam figuras penais da ordem internacional, como no caso das violações dos direitos à existência dos armênios pelo Império Otomano, mas também após a Primeira Guerra Mundial, quando o Tratado de Versalhes requereu a extradição dos alemães culpados de crimes de guerra. Da evolução expressa no item acima, enunciamos os princípios trazidos pela doutrina penal que definem as bases em que se constrói este ramo.

O pressuposto de partida para a existência de um direito internacional penal é que não seja necessária a intermediação estatal, a petição dirigida aos Estados para a persecução dos crimes previstos nesta órbita e, finalmente, que a punibilidade das infrações ocorra independente da intervenção do legislador estatal. Assim, JESCHECK conceitua o princípio da responsabilidade jurídico-penal direta do indivíduo segundo o direito internacional, devendo obter o necessário reconhecimento geral. O outro princípio norteador deste ramo é o princípio da preferência do direito internacional penal frente o direito estatal, em relação ao qual JESCHECK ${ }^{526}$ dá mostras de desconfiança em relação à sua efetividade: "atualmente não se dá nenhum dos dois pressupostos (preferência do direito internacional ou alteração do direito nacional para conformá-lo ao primeiro) e existe pouca esperança que haja em breve alguma mudança".

526 JESCHECK, H.H. "Nuremberg Trials". In: BERNHARD, R. (ed). Encyclopedia of Public International Law, Inst. 4, 1982, citado por GIL GIL, A. Op. cit., 1993, p. 110. 
Se um direito penal internacional já se consolida, como uma categoria criminal própria, há que se confrontar a teoria do bem jurídico como teste para as duas teorias a confirmar ou questionar seus respectivos rendimentos. Não é demais mencionar o caráter "Estado-cêntrico" do direito penal em relação ao monopólio do direito de investigar sob a égide do direito penal e de punir às violações por meio da aplicação de penas. O Estado, nas palavras de HORMAZÁBAL MALARÉE ${ }^{527}$, erige-se como um ente garantidor das condições de vida em comum contra as condutas socialmente danosas, ofensa sempre produzida contra o próprio Estado. $\mathrm{O}$ direito penal internacional, portanto, internacionalizando o bem jurídico tutelado, cria um mecanismo próprio, fora da órbita estatal, para sua perseguição, numa configuração muito mais fluida, inconstante, de execução casual, do dever universal de garantia de proteção de grupos sociais.

A análise a respeito da compatibilidade entre os marcos teóricos dos crimes contra a humanidade e o direito penal do bem jurídico procura entender de que forma o alargamento do conceito promove sua evolução ou sua desconfiguração, notadamente diante da tutela de novos interesses supraindividuais. Para FIGUEIREDO DIAS, está-se a um passo de "preconizar o aparecimento de uma nova dogmática jurídico-penal disposta a abandonar e substituir princípios até aqui tão essenciais como os da invidualização da responsabilidade penal e a considerar à nova luz questões como as da causalidade, da imputação objectiva, do erro e da culpa, da autoria. E assim, de novo a um passo de propugnar o abandono do direito penal do bem jurídico ou, pelo menos, a sua complementação por outro modelo capaz de responder às novas exigências assinaladas" ${ }^{25}$. Quiçá, por esse mesmo motivo, é de se sustentar que o direito penal internacional não está estruturado para ser tratado com as categorias do direito penal, dentro de suas instituições e procurando se aperfeiçoar dentro de sua filosofia.

\footnotetext{
${ }^{527}$ HORMAZÁBAL MALARÉE, Bien jurídico y Estado social y democrático de derecho. Madri: Ed. Trotta, 1991, p. 13.

${ }^{528}$ FIGUEIREDO DIAS, Jorge de. Direito Penal (...), op. cit., p. 136.
} 


\subsubsection{A problemática da teoria do bem jurídico em relação aos crimes do direito penal internacional}

Se a estrutura penal internacional nasceu para possibilitar a repressão a uma nova categoria de crime, a conceituação dos crimes contra a humanidade e sua problemática em torno do bem jurídico protegido não têm sido suficientemente debatidas no que elas inovam em termos de abertura conceitual e flexibilização do arcabouço teórico em direção à expansão do direito penal. Refiro-me ao movimento que está levando ao direito penal o chamado direito penal de quarta velocidade, considerando-se o direito penal dotado de um inegável caráter supranacional, tomando-se como ponto central de referência a comunidade cultural e os valores que subjazem às constituições ocidentais atuais ${ }^{529}$, mas que convive com as reduções de garantias penais e processuais penais, a informalidade e flexibilidade dos atributos de suas normas, mas também de uma aplicação seletiva.

A definição de crimes contra a humanidade elenca ações que violam, em última instância e de modo mais ultrajante, a existência ou manutenção física, da saúde física ou mental que, praticados de forma sistêmica, infligem os maiores sofrimentos a uma coletividade, conforme previsto no art. $7^{\circ}$ do Estatuto do Tribunal Penal Internacional nos seguintes termos:

\footnotetext{
"Para os efeitos do presente Estatuto, entende-se por "crime contra a humanidade", qualquer um dos atos seguintes, quando cometido no quadro de um ataque, generalizado ou sistemático, contra qualquer população civil, havendo conhecimento desse ataque:

a) Homicídio;

b) Extermínio;

c) Escravidão;

d) Deportação ou transferência forçada de uma população;

e) Prisão ou outra forma de privação da liberdade física grave, em violação das normas fundamentais de direito internacional;

f) Tortura;

g) Agressão sexual, escravatura sexual, prostituição forçada, gravidez forçada, esterilização forçada ou qualquer outra forma de violência no campo sexual de gravidade comparável;

h) Perseguição de um grupo ou coletividade que possa ser identificado, por motivos políticos, raciais, nacionais, étnicos, culturais, religiosos ou de gênero, tal como definido no parágrafo $3^{\circ}$, ou em função de outros critérios universalmente reconhecidos
}

${ }^{529}$ SILVA SÁNCHEZ, Jesús-Maria. La expansión del derecho penal (...), op. cit., p. 77. 
como inaceitáveis no direito internacional, relacionados com qualquer ato referido neste parágrafo ou com qualquer crime da competência do Tribunal;

i) Desaparecimento forçado de pessoas;

j) Crime de apartheid;

k) Outros atos desumanos de caráter semelhante, que causem intencionalmente grande sofrimento, ou afetem gravemente a integridade física ou a saúde física ou mental" (grifo nosso).

É bastante complexa a tarefa de indicar todas as ações que o senso comum tenderia a considerar como crimes contra a humanidade, a ponto de autores como DELMASMARTY ${ }^{530}$ incluir as tentativas de manipulação genética entre eles. BENERIA e SARASÚA chegam a propor a inclusão de crimes econômicos como crimes contra a humanidade ${ }^{531}$. Por mais incompleta que tenha sido a realização do mister, chegou-se a um rol bastante abrangente, mas do qual não se pode concluir que exista uma razão idêntica a orientar todas as inclusões, pois distintos são os bens jurídicos protegidos em cada tipo - a vida, a integridade física, liberdade, liberdade sexual, vida em comunidade. Mas a facilidade em se visualizar o crime materializado de formas tão diversas quanto cruéis torna sua conceituação tão complexa que se chega a um mosaico de descrições disforme. Para um dos mais importantes doutrinadores sobre os crimes contra a humanidade, BASSIOUNI, nas mentes populares o conceito de crimes contra a humanidade quer dizer qualquer ação atroz cometida em larga escala ${ }^{532}$. Ainda que se diga que os tipos delitivos tradicionalmente considerados como objeto do direito penal internacional protegeriam bens jurídicos individuais, alguns autores preferiram fundamentar a intervenção deste direito na relação buscada entre bens jurídicos individuais e a paz internacional, considerado este como o principal objeto de proteção do direito penal internacional.

A busca pela segurança do indivíduo frente o Estado todo-poderoso sempre foi o norte no desenvolvimento do direito penal, notadamente na teoria do bem jurídico, desde a insuficiência dos critérios indicados por FEUERBACH, de defesa dos direitos subjetivos, superada em função de uma certa plasmação de valores sociais essenciais. Essa ideia encontrou repercussão na teoria de BIRNBAUM, localizando na lesão de um bem, coletivo

\footnotetext{
${ }^{530}$ DELMAS-MARTY, Mireille. "Lo relativo y lo universal”, op. cit., p. 16.

531 BENERIA, Lourdes; SARASÚA, Carmen. "Crímenes económicos contra la humanidad", 3/4/2011, disponível em: http://www.sinpermiso.info/textos/index.php?id=4059 (Acesso. 03.10.2014).

532 Conforme Peter BUNS, "this general description is useful as a conceptual starting point but the modern law reveals crimes against humanity to be fairly specific and sometimes elusive.” BUNS, op. cit., 2007, p. 01.
} 
ou individual, o objeto de proteção penal. Com BINDING, entretanto, a fundamentação trazida por ele não nos parece servir, retirando um conteúdo ontológico próprio para defender a parte formal do conceito. Nesta seara, conforme BECHARA, para esta teoria, nem todo bem é suscetível de proteção penal, mas apenas aqueles dotados de relevância jurídica, "havendo absoluta congruência entre a norma e o bem jurídico por ela revelado" 533 . A absoluta aderência ao positivismo de BINDING desarmaria o direito internacional penal de um componente importante, que é sua origem no direito natural, no sentimento natural de crime em casos extremos, de pouca densidade normativa.

De maior densidade dentro de um direito estruturalmente costumeiro, o injusto penal na área internacional deve adotar uma perspectiva valorativa do bem jurídico, associada à formal, mas essencialmente preenchida pela criação e função da sociedade (inter)nacional consciente de suas finalidades, conforme HATTENHAUER citado por BECHARA $^{534}$.

Para FIGUEIREDO DIAS, trata-se de saber se o paradigma em cima do qual persistiu o conceito de bem jurídico penal irá prevalecer ou se existem no horizonte sinais da necessidade de uma "nova revolutio" na compreensão da função do direito penal no sistema social, para a "manutenção, alteração ou superação do modelo do direito penal do bem jurídico" 535 . A crise por que passa a discussão da teoria do bem jurídico deixou de ser uma pura polêmica jurídica para enfrentar-se com a questão fundamental político-criminal de dar carga ao que se quer proteger. Assim, encontramo-nos numa via de mão dupla, sabemos o que queremos proteger e definimos o conceito de bem jurídico penal para dar fundamento ao direito penal vigente ao mesmo tempo que fechamos a teoria do bem jurídico penal para justificar a criminalização de todos os ataques a estes ou sua colocação em perigo.

Infelizmente, como se vê, a discussão no âmbito legislativo para a definição de crimes não levantam nem se preocupam em direcionar os problemas apontados pela dogmática e de política-criminal, em sua essência, trazendo certa inconsistência, o que culmina por gerar as normais críticas acerca da imprecisão em relação ao que se queria

\footnotetext{
${ }^{533}$ BECHARA, Ana Elisa Liberatore. Da teoria do bem jurídico como critério de legitimidade do direito penal, mimeo, São Paulo, Tese de Livre Docência, Faculdade de Direito da Universidade de São Paulo, 2010, p. 96. ${ }^{534}$ HATTENHAURER, Hans. Los fundamentos histórico-ideológicos del derecho alemán. Madri: Editoriares de Derecho Reunidas, 1981, p. 286, citado por BECHARA, op cit., 2010, p. 99.

${ }^{535}$ FIGUEIREDO DIAS, Jorge de. Curso de Direito Penal, op. cit., 2007, p. 135.
} 
proteger. Assim sendo, a teoria do bem jurídico sofre de um mal comum nas ciências jurídicas: o descompasso entre a técnica jurídica, a vontade legislativa e a interpretação jurisprudencial que, tratando do mesmo assunto, mas calcadas em objetivos distintos, por assim dizer, podem chegar, e de fato chegam, a resultados divergentes.

A redução do conceito de bem jurídico ao núcleo essencial de valores imanentes a um mínimo ético consensual afasta a integração a este conceito do direito penal do risco, mas também dos crimes econômicos, tributários, ambientais, relacionados a estupefacientes, como faz referência FIGUEIREDO DIAS ${ }^{536}$, afirmando que a aceitação generosa de bens jurídicos universais abriria o risco para a afirmação de um direito penal de prima ratio, em violação da função garantidora do direito penal ${ }^{537}$. O uso da expressão "universal" não faz referência apenas aos crimes contra a humanidade, mas à ideia de um bem jurídico que de forma direta proteja os valores essenciais da vida em sociedade, coletivamente protegida, ou seja, em sua dimensão coletiva.

Procurando extrair o conceito de bem jurídico do entendimento do que se quer proteger, diversos autores debruçam-se buscando dar concreção ao conceito de crime contra a humanidade. Assim, GARIBIAN:

\begin{abstract}
"Estranho, o novo conceito de crime contra a humanidade o é no que ele carrega da hipótese que existiriam ações criminais cuja comissão, além das fronteiras e das nacionalidades, concerne 'todo o mundo', os ataques à humanidade inteira. 'Humanidade' à qual se refere é a que pode bem ser: um sentimento 'que exprima a bondade, sensibilidade, bem-aventurança, compaixão'? O gênero humano, a saber 'os homens em geral, o nome coletivo do conjunto que eles formam, a comunidade das nações'? Ou a natureza humana, 'a essência do homem, aquilo que faça dele um homem'?"538
\end{abstract}

Para COMPARATO, a vítima dessa modalidade delitivo é a própria humanidade, considerada em seu conjunto como sujeito de direito digno de tutela. Em tais condições, afirma o autor, salvo manifesto excesso normativo, "não se pode deixar de considerar que o interesse da humanidade sobrepuja, em regra, o da pessoa ou pessoas que

\footnotetext{
${ }^{536}$ FIGUEIREDO DIAS, Jorge de, idem, p.. 138)

${ }^{537}$ V. HASSEMER, "Lineamentos de una teoría personal del bien jurídico" (trad. Patrícia S. Ziffe), Doctrina Penal 12, 1989, p. 284.

${ }^{538}$ GARIBIAN, Sévane. Le crime contre l'humanité au regard des principes fondateurs de l'Etat moderne: Naissance et consécration d'un concept. Paris: Bruylant, 2007, p. 5.
} 
comparecem perante o Tribunal Penal Internacional na condição de indiciada ou acusadas" $" 539$. Nota-se, portanto, uma alta carga emocional e ideológica a orientar as fundamentações ligadas à criminalização das condutas em âmbito internacional.

Está em movimento, assim, nova instância de produção da norma penal, o campo internacional, na flexibilização do monopólio da produção jurídica estatal ${ }^{540}$, num processo decorrente da intensificação das relações internacionais por meio da globalização. Para a autora, recorre-se aos critérios de gravidade do crime e geração de repulsa na comunidade internacional para, no plano comportamental e normativo, diferenciar dos demais crimes aqueles que mereçam um tratamento internacional. Essa forma de detectar o objeto de proteção do direito penal internacional incide em falha comum, pois é calcada na ideia de um conceito de crime naturalístico, detectável no plano fático, e, pela escala de gravidade atribuível à conduta, pressupõe uma comunhão de interesses na comunidade internacional que não se sustentaria.

A criação do direito penal internacional responde, assim, a uma negação da impunidade $^{541}$, conquanto cobre o preço da superação do conceito de soberania a nacionalizar os aspectos de ação da norma penal, no fenômeno chamado de "criação política de crimes". Neste âmbito, podemos conceber que o bem jurídico dos crimes contra a humanidade possa ser qualquer deles, todos ou nenhum. Sendo universal, pode ter como referente o indivíduo, o social, mediado pela coletividade interessada na sua proteção, o supraindividual, orientado por uma coletividade não necessária e diretamente ligada à proteção do bem, mas genérica, ou nenhum, quando nenhuma dessas categorias consegue ser aplicada de forma absoluta. Isso porque em sede de crimes contra a humanidade, não se pode falar em crimes de perigo ou prevenção diante de danos de grande gravidade, inclusive

\footnotetext{
${ }^{539}$ COMPARATO, Fábio Konder. A Afirmação Histórica dos Direitos Humanos, $3^{\mathrm{a}}$ ed., São Paulo: Ed. Saraiva, 2003, p. 468.

${ }^{540}$ MACHADO, Maíra R. Internacionalização do direito penal. Ed. 34: São Paulo, 2004, p. 15 ss.

${ }^{541}$ Conforme abordado no capítulo $2^{\circ}$, as práticas relacionadas aos preceitos da justiça de transição têm sido saudadas por se concluir que a redução de impunidade contribui para a reconstrução democrática de estados. Ainda sendo um conceito novo, suas bases estão profundamente ligadas ao estabelecimento do sistema dos direitos humanos modernos. Suas raízes intelectuais, como afirma M. Cherif BASSIOUNI, remontam ao período após a I Guerra Mundial, quando se passou a considerar a importância da busca de justiça após as atrocidades cometidas durante o conflito. Essas primeiras considerações foram essenciais para a formulação das primeiras instituições de justiça de transição, criadas após a II Guerra Mundial, como os tribunais militares de Nuremberg e Tóquio, o que coincide com a criação das Nações Unidas, a irradiação da Declaração Universal dos Direitos Humanos. BASSIOUNI, M. Cherif. Crimes against Humanity in International Criminal Law, The Hague: Kluwer Law, 1999.
} 
em função do que trata FERMÍN MORALES PRATS a respeito dos interesses difusos e sua especial particularidade de se tratar de vulnerações apresentadas como uma disfuncionalidade do sistema ${ }^{542}$.

Segundo classificação de BUSTOS RAMÍREZ ${ }^{543}$, os bens jurídicos podem ser divididos entre aqueles que protegem bens individuais, sem os quais não é possível a existência de nenhum sistema social, e aqueles que dizem respeito ao funcionamento de um sistema, sem os quais o sistema é inoperante ou mal disfuncional. Aplicado ao âmbito do direito internacional, essa segunda categoria também é subdividida conforme segue:

a) bens jurídicos coletivos relativos a condições para o desenvolvimento dos bens individuais;

b) bens jurídicos institucionais que formalizam processos para a realização de outros bens jurídicos;

c) bens jurídicos de controle.

Pode-se entender como os bens da categoria "a" os bens jurídicos relacionados à proteção dos direitos coletivos voltados à efetivação dos direitos humanos; a categoria "b" pode ser aplicada às condições processuais de acesso à jurisdição internacional e a "c", por sua vez, a um sistema de controle, ainda inexistente, de eficácia da aplicação da norma penal internacional.

Localizados os crimes em direito penal internacional principalmente na categoria "a", abrangendo-se a paz, a segurança e a preservação das sociedades, fazemos referência ao Projeto de Código de Crimes contra a Paz e a Segurança da Humanidade, da CDI, de 1991, no qual se declara, repetindo o título, em seu artigo $1^{\circ}$ que "os crimes definidos no presente código constituem crimes contra a paz e a segurança da humanidade", ou quando resoluções do Conselho de Segurança das Nações Unidas estabelecem situações de violações

\footnotetext{
${ }^{542}$ Conceito que se adere aos direitos difusos, dos quais o sistema econômico não pode prescindir, mas cuja disfuncionalidade no seu exercício o direito deve regular. MORALES PRATS, Fermín, "Funciones del derecho penal y sociedad civil", Il Dirito Penale alla svolta di fine millenio, Torino: Giappichelli Editore, 1998, pp. 56 e ss.

${ }^{543}$ BUSTOS RAMÍREZ, Juan. Introducción al derecho penal. Bogotá: Temis, 1994.
} 
massivas, ações de limpeza étnica, do direito humanitário bélico como ameaças à paz e segurança internacional, declarando sua intenção em criar um tribunal internacional visando o reestabelecimento da paz $^{544}$.

\subsubsection{Expansão do direito penal e enfraquecimento da teoria do bem jurídico}

O direito penal fragmentariamente deve dar conta da proteção dos bens jurídicos de máximo valor quando e como ele possa revalidar o valor do bem violado. Em termos de crimes de religião, a carga protetiva é contestada: "nem, por outro lado, os instrumentos de que se serve para a sua actuação, as penas e as medidas de segurança criminais, se revelam adequados para fazer valer no corpo social as normas da virtude e da moralidade. Nem, ainda por outro lado, para a aplicação de um direito com um tal sentido se encontram credenciados os magistrados e os tribunais, por isso que instâncias legitimadas para castigo do pecado e da imoralidade só podem ser, respectivamente, a divindade e a consciência"545. Como lembra DIAS, o caráter fragmentário é justamente contraposto com a natureza, tendencialmente, completa e total da tutela religiosa e da tutela moral.

Nesse sentido, concordamos com a doutrina de FIGUEIREDO DIAS, para quem o eficaz domínio da criminalidade dentro de cotas socialmente suportáveis, pressupõe que o Estado deva intervir o menos possível, apenas na medida requerida pelo asseguramento das condições essenciais de funcionamento da sociedade, no denominado princípio da nãointervenção moderada ${ }^{546}$.

Se atualmente falar da teoria do bem jurídico penal implica necessariamente a abordagem da crise por que ela passa, o presente tema não poderia encaixar-se melhor no cerne dessa crise, seja para remodelar, revigorar ou abalar, mas sempre para justificar esta crise. A crise do bem jurídico decorre, em grande medida, da expansão incontida do direito penal, da ampliação do campo autoritário sobre a norma penal, como ocorrido com os

\footnotetext{
${ }^{544}$ Em especial, Resoluções no 771 de 1992, 808 de 1993, 827 de 1993 e 955 de 1994.

545 FIGUEIREDO DIAS, Jorge de. Direito Penal - Parte Geral, Tomo 1, 2ª ed. Brasileira, São Paulo: Ed. Revista dos Tribunais, 2007, p. 112

546 Idem, ibidem, p. 131.
} 
trabalhos originários da Escola de Kiel, quando os atributos verificados naquela ocasião (escolas de sustentação jurídica do regime alemão nacional socialista) superaram as condições históricas e ideológicas no nazismo para integrarem-se na prática legislativa de hoje em dia por meio de uma perspectiva disfarçada da sociedade atual, liberal, que é o autoritarismo. Essa profusão de normas penais configura o alarme trazido por STERNBERG-LIEBEN ${ }^{547}$ de que a teoria do bem jurídico cuja função crítica esteja desvinculada da realidade gera o risco de reduzir a zero sua capacidade de influir sobre a prática legislativa, ao mesmo tempo em que um direito penal absolutamente atado à realidade amarra-a em sua substância, privando-o de sua reavaliação e acomodação diante de valores vigentes em outros momentos.

Se, por um lado, a função fundamentadora segue seu rumo com menos abalo, é na função crítica que encontramos mais ataques, diante do fenômeno da expansão do direito penal para cuidar de todos os campos de intervenção estatal relevante na vida dos indivíduos, da sociedade, da economia. Essa expansão decorre da busca por controle do Estado, tanto na esfera administrativa, quanto de segurança. Assim, o direito penal adota a "função de ordenação e realiza sua função para a proteção de circunstâncias sociais que conformam a liberdade do cidadão", nas palavras de STERNBERG-LIEBEN ${ }^{548}$, permitindo que na tomada do campo de segurança o Estado afirme sua real dimensão na sociedade - segurança do Estado para a vida livre do cidadão. Assim, a função limitadora, para o autor, tropeça na realidade de um conjunto de normas penais parcialmente incompatíveis com o conceito de bem jurídico. Há que se ponderar que não há necessariamente uma correlação absoluta entre as condições objetivas de segurança e o sentimento de segurança, o segundo, em geral, sobrepujando o primeiro, conforme aborda SILVA SÁNCHEZ, resultado de uma socialização em alta velocidade, perde o referencial protetivo na mundialização das esferas jurídicas $^{549}$.

A abertura do conceito de bem jurídico é conveniente, assim como o é no conceito de direitos humanos, como elemento de construção histórico-social, permanecendo

\footnotetext{
${ }^{547}$ STERNBERG-LIEBEN, Detlev. "Bien jurídico, proporcionalidad y libertad del legislador penal". In: HEFENDEHL, Roland. La teoria del bien jurídico: ¿Fundamento de legitimación del derecho penal o juego de abalorios dogmático? Madrid: Marcial Pons, 2007.

${ }^{548}$ STERNBERG-LIEBEN, Detlev. "Bien jurídico, proporcionalidad y libertad del legislador penal", op. cit., 2007 , pp. 120 ss.

${ }^{549}$ V. SILVA SÁNCHEZ, Jesús-Maria. A expansão do direito penal (...), op. cit.
} 
o cuidado de que ao tentar abranger tudo, pode não corresponder a nada. Assim, mediará sempre, tanto no bem jurídico individual, quanto suprainvidividual, na proteção das unidades funcionais, o princípio da proporcionalidade aplicado ao direito penal à hora de determinação do injusto punível, como limite de todas as medidas estatais restritivas de direitos, segundo STERNBERG-LIEBEN ${ }^{550}$.

A mão que molda o conceito de crime contra a humanidade define o que seja digno de proteção da norma penal se o bem jurídico protegido corresponder aos interesses de máxima envergadura numa sociedade nacional ou internacional. Entretanto, se a teoria do bem jurídico não for suficientemente aberta para acomodar as novas concepções criminais da sociedade moderna, é o molde que não serve e não a mão. A mão servirá, portanto, para remoldar o conceito e não o conceito para remoldar a mão. Esta ponderação, expressa de forma bastante simplória, não dá conta de frear surtos emancipatórios, como o da sociedade do risco e a percepção distorcida do sentimento de segurança diante das condições objetivas de segurança, por exemplo, mas o fechamento da teoria do bem jurídico penal imune à valoração da comunidade criaria um direito penal cego e surdo e, por isso, mudo ao falar do núcleo do injusto naquela sociedade. STERNBERG-LIEBEN ${ }^{551}$, para quem o bem jurídico coletivo há de ter um referente individual, identifica a importância da prática valorativa e do grau de intensidade do perigo para os bens socialmente valorados para que se entreveja a relatividade cultural e a temporalidade do delito, dando o exemplo de que, numa sociedade crente dos fenômenos paranormais, o conceito de bem jurídico não poderia opor-se de forma absoluta à perseguição da bruxaria.

A expansão do direito penal, nesse sentido, é uma crise necessária a imprimir ao conceito de bem jurídico penal uma necessária reavaliação, sem o que ele perderia sua dimensão essencial de proteção dos grandes valores sociais, ficando fechado à porosidade mútua que deve haver entre a sociedade e suas normas jurídicas, extraindo-se o bem jurídico da própria sociedade.

\footnotetext{
${ }^{550}$ Idem, ibidem, p. 120.

${ }^{551}$ STERNBERG-LIEBEN, Detlev. "Bien jurídico, proporcionalidad y libertad del legislador penal", op. cit., 2007, p. 119.
} 
No primeiro julgamento de condenação pelo TPII, no caso Erdemovic ${ }^{552}$, em 1996, consoante já pudemos abordar, afirmou-se o caráter transcendente do interesse objeto da tutela penal internacional:

\begin{abstract}
"De maneira oposta ao direito ordinário, as violações presentes não são dirigidas ao bem-estar físico apenas da vítima, mas da humanidade como um todo. Crimes contra a humanidade são atos sérios de violência que vitimam todos os seres humanos ao atingir o que é mais essencial a eles: suas vidas, liberdade, bem-estar físicos, saúde e ou dignidade. São atos desumanos que por sua extensão e gravidade ultrapassam o limite do tolerável à comunidade internacional, que deve perseguir sua punição. Mas os crimes contra a humanidade também transcendem o indivíduo porque quando o indivíduo é atacado, a humanidade fica sob o ataque e ela é negada. É, portanto, o conceito de humanidade como vítima o que essencialmente define os crimes contra a humanidade" (grifo nosso).
\end{abstract}

O direito internacional penal seria, assim, baseado em valores comuns partilhados pela comunidade internacional, não mais como um mito, mas que tende a tornarse uma realidade, "ainda muito frágil, que precisaria ser construída e consolidada"553. Paul Ricoeur encetou a seguinte reflexão: "Não podemos encontrar remédio para uma simbologia comum?", ao que DELMAS-MARTY ${ }^{554}$ repergunta se no prolongamento destas preocupações em que medida os crimes internacionais poderiam ser o esboço de uma simbologia comum? Para entrarmos no campo penal, efetiva e inescapavelmente, deve-se enfrentar a missão na busca de valores comuns, "não apenas a enumeração de comportamentos criminosos, mas também a definição desse fundo comum de valores que chamamos Humanidade".

\footnotetext{
${ }^{552}$ Caso Drazen Erdemovic, TPII, (IT-96-22-T), sentença de 29.11.1996 (trad. livre). No original: “As opposed to ordinary law, the violation here is no longer directed at the physical welfare of the victim alone but at humanity as a whole. Crimes against humanity are serious acts of violence, which harm human beings by striking what is most essential to them: their life, liberty, physical welfare, health, and or dignity. They are inhumane acts that by their extent and gravity go beyond the limits tolerable to the international community, which must perforce demand their punishment. But crimes against humanity also transcend the individual because when the individual is assaulted, humanity comes under attack and is negated. It is therefore the concept of humanity as victim which essentially characterizes crimes against humanity."

${ }^{553}$ DELMAS-MARTY, Mireille. A imprecisão do direito - do código penal aos direitos humanos. (Trad. Denise Radanovic Vieira). Ed. Manole: Barueri, 2005, p. 66.

${ }^{554}$ Idem, ibidem, pp. 70 e 71.
} 


\section{CAPÍTULO $4^{\circ}$ - O DIREITO DE PUNIR INTERNACIONALMENTE E SUA CRÍTICA}

O quarto capítulo sintetiza os principais aspectos problemáticos da expansão do direito penal pelos direitos humanos no contexto do direito penal internacional, partindo da origem do direito de punir na esfera internacional e refletindo sobre as fragilidades de seu processo de consolidação. Ao expor as fraturas desse processo, questiona-se a função preventiva das normas dissociadas da função subsidiária direito penal e, da órbita internacional, sem condições de se integrar às perspectivas de construção de justiça social.

\subsection{Premissas do Direito de Punir Internacionalmente}

\subsubsection{Considerações sobre a origem do direito de punir}

O direito de punir na esfera internacional decorre da: a) autoridade originária; b) da aplicação das penas justas e iguais a todos os condenados; c) da natureza recíproca e comensurável das penas em relação às violações e extensão do dano produzido e; d) porque representa o justo merecimento ("just desert"), nas palavras de BASSIOUNI ${ }^{555}$. O direito de punir internacionalmente deriva de algumas premissas: segundo a premissa do contrato social, o sistema de justiça criminal internacional, como o nacional, é baseado no pressuposto do pacto social, que consiste no dever de cada indivíduo cumprir as normas em troca do dever da comunidade internacional prover segurança para seus cidadãos por meio do exercício do poder punitivo.

O direito histórico de punir advém da retirada do poder individual do exercício da vingança. A vingança baseada na Lei de Talião do Talmud aplicava a retribuição da ofensa

\footnotetext{
${ }^{555}$ AMBOS, Kai; STEINER, Christian. "On the rationale of punishment (...)”, op. cit., p. 316. Em semelhante sentido, SIEBER, Ulrich afirma que essas características identificam e singularizam determinados sistemas de justiça criminal dos outros, advertindo que "if criminal laws does not respect deep-seated cultural and economic differences, citizens may refuse to accept invidual criminal provisions". "The forces behind the harmonization of criminal law". In: Delmas-Marty, Mireille; PIETH, Mark; SIEBER, Ulrich (orgs.). Les chemins de l'harmonisation pénale. Paris: Parution, 2008, p. 388.
} 
ao ofensor, favorecendo uma grande ruptura social e conflutiosidade constante em torno da disputa instaurada. Atualmente, ainda que exista alguns sistemas tradicionais islâmicos a aplicar o direito individual da vítima nos termos taliônicos da retribuição contra o perpetrador da ofensa ${ }^{556}$, praticamente todos os sistemas jurídicos contemporâneos separam o direito da vítima à indenização civil, que permanece como direito da vítima, e a esfera de punição criminal, que pertence ao Estado. A punição, na opinião de BASSIOUNI, seria essencial para a ordem mundial, ainda que seu efeito seja essencialmente retributivo. Para AMBOS e STEINER, entretanto, seria no equilíbrio entre os dois efeitos (retributivo e preventivo) que contribuiria para a realização da justiça em abstrato: o sofrimento do ofensor é aceito apenas e tão somente como efeito do reequilíbrio da balança, embora o direito internacional de punir baseie-se na ideia de prevenção geral.

A identificação do dever de punir que existiria na comunidade internacional tem adeptos, como decorrência da premissa da retributividade, associada à dinâmica de funcionamento do contrato social, que também integra o reconhecimento do direito da vítima de esperar que a ordem jurídica, nacional ou internacional, julgue e puna os violadores das normas conforme a culpabilidade apurada, assim como garanta as possibilidades da vítima obter reparações civis ${ }^{557}$. AMBOS e STEINER ${ }^{558}$ também sustentam a existência de um ius puniendi fundado no direito penal internacional, com monopólio do poder de violência legal, embora com funcionamento menos urgente do que no âmbito nacional à primeira vista $\mathrm{e}, \mathrm{em}$ relação ao TPI, com funcionamento subsidiário.

Relembra AMBOS e STEINER ${ }^{559}$ que a noção de justiça em direito penal internacional no exercício do seu poder punitivo não deve descurar das características culturais, religiosas ou tradicionais de cada sociedade, ou também referido como direitos humanos interculturalmente reconhecidos ${ }^{560}$. Isso, entretanto, não implica aceitar ou justificar a prática de atos que de forma mais grave atingem os valores da humanidade, mas

\footnotetext{
${ }^{556}$ BASSIOUNI, M. Cherif. Les crime relevant du prècept de Qesas. 4 Revue Internationale de Criminologie et de Police Technique 485 (1989); BASSIOUNI, M. Cherif. Death Penalty and the Shari'a. International Commission of Jurists, 65, 2000.

${ }^{557}$ BASSIOUNI, M. Cherif. "International criminal justice in the age of globalization". Nouvelles Études Pénales 19, AIDP, 2004, pp. 97 ss.

558 AMBOS, Kai; STEINER, Christian. "On the rationale of punishment at the domestic and international level”. In: HENZELIN, Marc; ROTH, Robert. Punir les criminels internationaux, Paris: LGDJ, 2002, p.317. ${ }^{559}$ AMBOS e STEINER, "On the rationale of punishment (...)", op. cit., p. 317.

${ }^{560}$ AMBOS, Kai. Temas de Derecho Penal Internacional y Europeo. Madri: Marcial Pons, 2006, p. 25.
} 
que o fato de Estados frequentemente impedirem a punição destes crimes ou, inclusive, não aceitarem a jurisdição internacional do TPI, deve-se em geral a questões relacionadas ao contexto político nacional, às conformações de seus sistemas de justiça, e não à rejeição dos valores expressos do sistema penal internacional.

Prevalece modernamente o entendimento de que o direito penal serve um propósito em particular, o de garantir a proteção da convivência pacífica dos seres humanos em comunidade, cujas origens passam por PLATÃO ${ }^{561}$ e SÊNECA ${ }^{562}$, VON LISZT $^{563}$ até os dias atuais, com ROXIN ${ }^{564}$ e $\operatorname{AMBOS}^{565}$. O direito penal internacional seria uma transposição desta função de garantia da pacificação num âmbito dominado pelas relações interestatais, além das singularidades relacionadas ao âmbito universal de aplicação e voltado à proteção dos valores jurídicos fundamentais da comunidade.

AMBOS e STEINER ${ }^{566}$ são cautelosos em afirmar as semelhanças entre o sistema penal nacional e internacional, e trabalham sob a perspectiva de que se estão lançando as primeiras pedras que irão pavimentar esse novo campo, ainda em busca de uma consciência legal universal cujos preceitos ainda que fundados na prevenção geral positiva, deverá redundar em efeitos da prevenção geral negativa.

Não podemos concordar que o modelo de poder punitivo exista à semelhança do que existe internamente, pelo fato de que o poder punitivo internacional ainda é exercido tendo por base os concertos da política internacional, não é um poder que se exerce de forma minimamente homogênea para garantir a equidade, previsibilidade e efetiva comunicação dos efeitos de prevenção e retribuição da pena. É um modelo imperfeito e rudimentar, quiçá muito menos na forma como está normativamente se consolidando e mais na forma como se apresenta na presente realidade.

${ }^{561}$ PLATÃO, Livro XI, 934, no qual afirma, por meio de seus diálogos: “And he shall pay the penalty, not because of the wrongdoing,- - for what is done can never be undone,-but in order that for the future both he himself and those who behold his punishment may either utterly loathe his sin".

562 SENECA, De ira, I, cap. XIX-7, sobre o poder dissuasório da pena.

563 haber em relação ao Programa de Marburgo.

${ }^{564}$ ROXIN, Claus. Derecho Penal-Parte General, T. 1, op. cit.

565 AMBOS, Kai; STEINER, Christian. "On the rationale of punishment at the domestic and international level”. In: HENZELIN, Marc; ROTH, Robert. Punir les criminels internationaux, Paris: LGDJ, 2002, p.305. 566 Idem, ibidem, op. cit., p. 323. 


\subsubsection{Expansionismo e o DPI das Cortes}

Temos assistido a promoção de mecanismos de justiça supranacional diante das fragilidades encontradas para o processamento dos crimes internacionais no âmbito da justiça nacional, numa prática "de cima para baixo", construída diante da gravidade e atrocidade dos crimes, a demandar uma reprovação mais contundente da comunidade internacional. Entretanto, os tribunais penais internacionais tendem a ser geograficamente mais inacessíveis às vítimas e testemunhas, com importantes efeitos em relação à participação do processo e resultados do julgamento. Além dos custos e inconvenientes em empreender tamanho esforço, que pesam ainda mais para aqueles com mais dificuldades de suportar esforços físicos ou financeiros, também essa distância física representa uma maior dissociação normativa, até o ponto de que as vítimas seriam completamente estranhas aos procedimentos empreendidos ${ }^{567}$. Uma corte, cujos participantes centrais sentem-se sem relevância, tanto na forma de apropriação política quanto investimento emocional, não terá autoridade moral para dar uma decisão, falhando na comunicação de uma censura significativa diante dos crimes hediondos praticados, na capacidade de promover a reconciliação individual e do grupo, de contribuir para a revelação da memória histórica e reconstrução política, conforme observa ROBERTS e MCMILLAN ${ }^{568}$.

O caso da realização da justiça no genocídio ruandês coloca um problema clássico que teremos que enfrentar no momento de debater os efeitos do direito penal internacional em seu contexto expandido. Temos, assim, que refletir sobre a assimetria de penas quando o Tribunal Internacional de Penal para Ruanda - TPIR, ao decidir pela pena máxima de prisão perpétua para os planejadores e líderes do genocídio de 1994, ao passo que os tribunais locais de Ruanda, sentenciando os oficiais menos graduados, foram condenados à pena capital. Isso nos faz refletir sobre o tipo de comunicação que o TPIR foi

\footnotetext{
${ }^{567}$ DAMASKA avalia a pressão sofrida pelas vítimas e testemunhas durante um vigoroso interrogatório, pela técnica do cross-examination, chegando a afirmar que "the court is there to protect vulnerable witness from inappropriate queries. But judges are in many situations reluctant to interfere with the vigorous crossexaminations, for fear of crossing the fine line beyond which the defense has reason to complain that it was prevented from putting the prosecution's witnesses to an adequate test". DAMASKA, Mirjan R. "What is the point of international criminal justice?”, in Yale Law School, Faculty Scholarship Series, Paper 1573, 2008, p. 343.

${ }^{568}$ ROBERTS e MCMILLAN, “For criminology (...)”, op. cit., p. 332.
} 
capaz de veicular à população local ${ }^{569}$, enquanto a comunidade jurídica pudesse aceitar com mais facilidade essa incoerência, questionando o próprio critério de seletividade do julgamento ${ }^{570}$, que tivesse sido mais amplo, teria beneficiado os oficiais de baixo escalão, condenados à pena de morte. Essa reflexão obviamente não pretende que o TPIR aplicasse penas de morte, mas também a resposta de que cada poder judicial atua em seus limites e conforme sua competência, portanto uma decisão (nacional) não tem reflexos sobre a outra (internacional), deixa perplexo o sentimento de justiça diante das soluções incongruentes. $\mathrm{O}$ fato coloca em evidência a descontinuidade que a justiça penal internacional representa em relação aos sistemas nacionais, e mais, a incapacidade de comunicar suas fundamentações jurídicas para o exercício do seu poder punitivo, a influenciar os próprios Estados nacionais nos quais ela exerce sua competência jurisdicional internacional. Resvala na incapacidade de aderência da justiça local ao direito produzido nas cortes internacionais, produzindo decisões incoerentes ou contraditórias, comunicando uma face indesejável da fragmentação do direito.

Reconhece-se, assim, a complexidade da relação entre o TPIR e as cortes nacionais, quiçá muito mais pelas características dos próprias dos distintos sistemas judiciais, do que a distância em si do local dos fatos, Ruanda, da sede do TPIR, em Arusha, Tanzânia. ALVAREZ concorda que o julgamento pelas cortes ruandesas seria preferível ao julgamento pelo TPIR visto que a justiça local é mais acessível, mais compatível com as expectativas da comunidade e pode apresentar maiores oportunidades para o controle dos procedimentos civis e criminais ${ }^{571}$, embora a produção das condenações às penas de morte choque a comunidade internacional, sendo incontrolável o resultado fora da intervenção internacional.

\footnotetext{
${ }^{569}$ Reflexão proposta por ROBERTS e MCMILLAN, “For criminology (...)”, op. cit., p. 333. Para os autores, o processo supranacional estandardizado esconde características únicas de cada instância da criminalidade internacional ou de violações maciças de direitos humanos. Em contextos complexos que chega a levar ao cometimento de crimes tão graves como o genocídio, os criminólogos preferem evitar as soluções generalizantes, fazendo uso cada vez mais de informações e bases criminológicas, metodologias de investigações empíricas e análise cultural comparativa.

${ }^{570}$ A esse respeito, DAMASKAS, Mirjan R. "What is the point of international criminal justice?", op. cit., pp. 360-3, representando esse problema um dos temas centrais da crítica ao trabalho da justiça criminal internacional. A autora ressalta que não é a seletividade de se processar apenas uns dos envolvidos no crime, mas o de que os processos judiciais são iniciados principalmente contra cidadãos de estados que são atores frágeis na arena internacional ou que fracassou em obter apoio das nações poderosas.

571 ALVAREZ, José E. "Crimes of States/ Crimes of Hate: Lessons from Rwanda", Yale J. Intl. Law, 365, 1999, p. 462.
} 
Finalmente, reconhece-se que o resultado das atuações dos tribunais internacionais produzem efeitos para além do jurídico, indicando uma necessidade clara de se pensar a política internacional em termos de suas relações com os sistemas políticos e jurídicos domésticos. Conforme KOSKENNIEMI ${ }^{572}$, a universalização do princípio do Estado de Direto demanda a realização da responsabilidade criminal tanto nas esferas nacionais quanto internacionais e, na visão liberal, não deve haver espaço para os fora-dalei, a despeito do local, tempo, ranking, todos devem ser responsáveis pelos seus atos.

Com relação à situação da justiça local, um dos pilares da reconstrução de instituições pós-conflito ${ }^{573}$, registrou-se um aporte de doações em mais de US\$ 17 milhões para a administração da justiça, mas com um funcionamento ainda pobre. É evidente que para um sistema de justiça funcionar de forma que respeite os parâmetros do Estado de Direito, não basta um grande volume de dinheiro, mas de garantias sociais e políticas, dentro de um contexto social que legitime o império da lei, para que este sistema atue de forma imparcial, efetiva e que respeite os compromissos internacionais de direitos humanos. Em um artigo do Embaixador de Ruanda nos Estados Unidos, Theogene RUDASIGWA ${ }^{574}$, indicou que havia mais de centenas de promotores de justiça no país, a maioria dos quais com formação no ensino médio apenas. Entretanto, havia apenas 60 advogados privados em todo o país. Os reflexos no funcionamento da justiça são claros, em vista do relatório publicado pela Human Rights Watch ${ }^{575}$ : mais de 100 pessoas foram condenadas à morte por genocídio pelas cortes locais em 1997, apesar de preocupações de que em alguns casos o próprio julgamento tenha desrespeitado os padrões internacionais do devido processo legal, para não falar da pena de morte, inaplicável no âmbito do direito penal internacional.

\subsection{Tendências Críticas ao Expansionismo Penal do DPI}

\footnotetext{
572 KOSKENNIEMI, Martii. "Between Impunity and Show Trials”, Max Planck UNYB, 6, 2002, p. 2.

573 Cf. nossa dissertação de mestrado, BELTRAME, Priscila Akemi. "Acesso à Justiça e reconstrução de instituições nos contextos pós-conflito". Faculdade de Direito da USP, 2011.

${ }^{574}$ RUDASINGWA, Theogene. "The Rwanda Tribunal and its Relationship to National Trials in Rwanda", 13, American University International Law Review, 1469, 1998, pp. 1489-1490.

${ }^{575}$ HUMAN RIGHTS WATCH, Rwanda: Human Rights Developments, World Report 1999 (disponível em http//:www.hrw.org/hrw/pubweb/Webcat-84.htm\#P1339_175409).
} 


\subsubsection{Entre direitos e perplexidades}

O direito penal internacional pode ser sistematizado de acordo com as tônicas de 3 principais fases ${ }^{576}$ : a) a primeira, formativa, cujo objetivo era o de formular as regras principais para a realização de seu objetivo principal, o de evitar a permanência da impunidade, com base no conceito da justiça substantiva, punindo as graves condutas que causem dano e sofrimento, ainda que estas não sejam previstas previamente no âmbito criminal; b) a segunda fase, já mais madura, tendo por escopo a consolidação de um corpus jurídico que permitisse o embasamento da punição dentro da doutrina do princípio da legalidade ${ }^{577}$; c) e o terceiro, uma fase reflexiva, cujo objetivo é o de reavaliar as instituições de direito penal internacional sob a luz dos traços distintivos da criminalidade internacional.

A primeira fase sem dúvida não é incompatível com a terceira, pois a atividade reflexiva deve ser inclusive anterior a própria posta em marcha do poder punitivo internacional. E nisso nos afastamos de BASSIOUNI, que separa o crime e o dever de punir da justiça social, reconhecendo nesse aspecto a diferença entre o direito nacional e o internacional ${ }^{578}$. O direito penal internacional não teria por função dialogar com um contexto social localizado, refletindo um programa estruturado de cidadania, com impacto positivo e reforçado pela contenção do poder punitivo, mas evitar a impunidade dos graves crimes. Embora o direito penal não tenha missão civilizatória, ele é um poderoso reflexo dos valores civis que orientam a sociedade, que não se constrói aquém desses valores, sob pena de repetir um plano autoritário ou ineficaz.

Um bom exemplo da nossa discussão que desfoca o direito penal internacional dos princípios que orientam o direito penal diz respeito à flexibilização do princípio da

\footnotetext{
${ }^{576}$ Conforme CHOULIARAS, Athanasios. "Bridging the gap between criminological theory and penal theory within the international criminal justice system". European Journal of Crime, Criminal Law and Criminal Justice 22, 2014, p. 252.

577 GROVER, Leena considera como origem do direito penal internacional a realização da justiça substancial por meio de aspirações de respeito ao princípio da estrita legalidade, assim como CHOULIARAS, nota supra 578, considerando o processo de maturação desta nova área. "A call to arms: fundamental dilemmas confronting the interpretation of crimes in the Rome Statute of the ICC". European Journal of International Law, 21, 3, 2010, p. 551. Ponderando sobre a exatidão das definições criminais legais, ZEDNER afirma que "as definições legais sozinhas não podem adequadamente reconhecer o desenvolvimento histórico, as relações sociais, práticas, ideologias e interesses que determinam o que, num dado momento, é considerado crime". ZEDNER, L. Criminal Justice, Oxford: Oxford University Press, 2004, p. 69 (trad. livre).

${ }^{578}$ BASSIOUNI, M. Cherif. "International Criminal Justice in the Age of Globalization”, op. cit., p. 93.
} 
legalidade. Como uma etapa no processo de consolidação do direito penal internacional e da criminalização dos direitos humanos, sua efetivação no plano internacional apresenta um paradoxo: o que parece ser um meio de defesa dos direitos humanos acaba sendo a própria fonte de violação dos direitos humanos, levando a discussões travadas a respeito da "teoria da crise de identidade" 579 ou da teoria da "cultura da alegalidade em direito penal internacional" 580 , a refletir sobre esse papel ambíguo, da própria racionalidade da defesa dos direitos humanos. A fragilidade traçada decorre de um problema de linguagem em geral vaga, imprecisa, incorreta e repleta de truísmos e um fluxo perpétuo de abuso das palavras, em relação aos direitos humanos, a uma tendência a que se opõe BENTHAM ${ }^{581}$, explicitada em seu Anarchical Fallacies, a respeito da Declaração Universal dos Direitos Humanos, da ONU (1948).

A ambiguidade dos direitos humanos é abordada na teoria da crise de identidade de ROBINSON, que procura explicar porque doutrinas radicalmente liberais apoiam doutrinas iliberais e, em relação às ciências criminais, essa sensibilidade liberal se concentra na restrição do uso do poder coercitivo contra indivíduos. Entretanto, no direito penal internacional, o julgamento e a condenação são em geral conceituados como a realização dos direitos humanos das vítimas a uma punição. Identifica-se, assim, um recurso dos direitos humanos ao aparato do direito penal, não como limitador do poder punitivo estatal, mas como fundamentador da aplicação de uma pena que inflige dor, ou seja, um direito penal primitivo, um direito penal da punição. Nesse sentido, invertendo-se o sentido original, a investigação e condenação pelo direito penal internacional correspondem a uma forma de "exaurimento" do direito da vítima a uma resposta estatal, revolvendo os conceitos de uma maneira artificiosa. Não se trata apenas, nos dizeres de $\mathrm{ROACH}^{582}$, de uma sensibilidade exacerbada ao direito das vítimas, mas há que se reconhecer que os pressupostos normativos dos direitos humanos internacionais e do direito humanitário tendem a ser aplicados acreditando-se que estes o são de acordo com as técnicas legais adequadas.

\footnotetext{
579 ROBINSON, Darryl. "The identity crisis of international criminal law", Leiden Journal of International Law, 21, 2008, pp. 925-936.

${ }^{580}$ DUBBER, M. "Common civility: the culture of alegality in international criminal law". Leiden Journal of International Law, 24, 2011, pp. 923-936.

${ }^{581}$ CALHEIROS. Maria Clara. "A crítica aos direitos do homem. Notas à luz das Anarchical Fallacies de Jeremy Bentham". In: HOMEM, Antonio Pedro Barbas; BRANDÃO, Cláudio. Do direito natural aos direitos humanos (orgs). Coimbra: Almedina, 2014, pp. 25 ss

${ }^{582}$ ROACH, K. "Four models of the criminal process", 89, Journal of Criminal Law and Criminology, p. 671, 1999
} 
Afirma-se, nesse sentido, que esse movimento seja um passo atrás em relação aos direitos humanos ${ }^{583}$, visto que a análise do Estatuto do TPI leva à conclusão do baixo poder de prevenção dos crimes previstos, representando um puro efeito simbólico, carente de valor instrumental adicional considerável ${ }^{584}$. Também que a resposta concentrada no caráter punitivo individual, que concentre os esforços na responsabilidade individual, "pode desviar a atenção da causação sistêmica, corporativa, geopolítica e socioeconômica da criminalidade internacional" ${ }^{\prime 585}$.

Outro elemento a indicar a falha do direito penal internacional para o exercício de seus pressupostos punitivos é que o próprio conceito de crimes internacionais foi forjado apesar da ausência de correlatos mecanismos que ordenasse a responsabilidade penal internacional ${ }^{586}$, o que fica patente no debate apresentado no capítulo 3 sobre as diversas teorias extensivas de autoria do fato. Igualmente, com a definição dos crimes, primeiro eles foram enunciados para posteriormente se criar um sistema de punição.

Essa abordagem crítica precisa ser abonada pelo direito penal, com instrumental crítico próprio. O direito penal entrou, em verdade, pela porta dos fundos do direito penal internacional: primeiro para referendar a marcha punitiva em direitos humanos e no âmbito internacional, supranacional, e somente posteriormente para se encontrar embasamento que trouxesse a prática internacional para o Iluminismo ${ }^{587}$.

583 TEITELBAUM, A. "Statute of the ICC: a critique", Social Justice, 26, 1999, pp. 107-114.

${ }^{584}$ MULLINS, C.W.; ROTHE, D. "The ability of ICC to deter violations of international criminal law: a theoretical assessment”, International Criminal Law Review, 10, 2010, pp. 771-786. ROTHE, D.; COLLINS, V.E. “The ICC: a pipe dream to end impunity?”, 13, International Criminal Law Review, 13, 2013, pp. 191209. KREVER, T. questiona a capacidade de punição individualizada como forma de solução ou processamento de um fenômeno mais amplo de violência e atrocidade, afirmando que esse tipo de abordagem "corre o risco de naturalizar as fontes estruturais e sistêmicas do conflito e violência e de ofuscar os limites inerentes do potencial progressivo do direito penal internacional para colocar fím à violência e atrocidade". "International Criminal Law: an ideology critique", Leiden Journal of International Law, 26, 2013, p. 702 (trad. livre).

585 ROBERTS, P.; MCMILLAN, N. "For criminology in international criminal justice", Journal of International Criminal Justice, 1, 2003, p. 331.

586 JARDIM, Tarciso dal Maso. "A contribuição da justiça internacional penal: formação de paradigmas". Revista Anistia, vol. 9, p. 150.

${ }^{587}$ Conforme PASTOR, Daniel. "Essa compreensão universal do penal, baseada na tradição liberal e ilustrada, supõe - de modo indiscutível e à luz da evolução de mais de dois séculos - que o direito punitivo deve ser visto sistematicamente com desconfiança, com cuidado, com temor, com reserva, pois é um mecanismo violento e desafortunado, por demais inclinado a facilitar o abuso e a arbitrariedade daqueles que o aplicam." PASTOR, Daniel. El poder penal internacional. Una aproximación jurídica crítica a los fundamentos del Estatuto de Roma. Barcelona: Atelier, 2006, p. 23 (trad. livre). 
É comum se pensar na pluralidade de atores liberais (como organizações nãogovernamentais ${ }^{588}$ ou acadêmicos), cujos sistemas nacionais protegem de forma vigilante os acusados e que estão, nas palavras de ROBINSON, entre as vozes mais estridentes defendendo as definições e modos de responsabilidade amplos, assim como restritos campos de defesa, com vistas a garantir as condenações e, portanto, assegurar o direito das vítimas à justiça ${ }^{589}$. A dificuldade em fazer avançar as teses de defesa ficou claro no caso Edermovic $^{590}$, quando o tribunal afastou a alegação de estado de necessidade dele que sustentou que a única forma de Edermovic ser inocente seria estar morto. Isso porque Edermovic havia se alistado numa unidade não combatente e quando chegaram a uma fazenda, fora informado que deveriam assassinar os muçulmanos de lá. Tendo se objetado à ordem, foi-lhe dito por seu comandante: "se você tem pena deles, alinhe-se a eles e mataremos você também". Diante de alternativa cruel de perder sua vida sem conseguir salvar a de ninguém, acabou por cumprir a ordem ilegal. Por razões de consciência, reportou o crime e declarou-se culpado, como foi condenado, apenas com base em sua confissão ${ }^{591}$.

A opinião dissidente do juiz Antonio Cassese pondera elementos que consideramos mais ajustados para fundamentar a condenação por um tribunal penal

\footnotetext{
${ }^{588}$ A respeito da alteração do discurso das ONGs, alguns autores reconhecem seu protagonismo e afinidade especialmente em relação a questões procedimentos, mas em relação aos princípios substantivos, elas tendem a apoiar princípios gerais de inculpação, e a resistir aos princípios de exculpação. V. BILDER, Richard; WILSON, R. J. "Defences in Contemporary International Criminal Law", 96, AJIL, 2002, pp. 517-522. A respeito da posição das ONGs, BOOT, Machteld. Genocide, Crimes against Humanity, War Crimes: Nullum Crimen Sine Lege and the Subject Matter Jurisdiction of the International Criminal Court. Antwerpen: Intersentia, 2002, p. 614, trazendo um relatório com a proposta das ONGs de "fornecer diversas definições de crimes de caráter aberto ou de alargar as definições existentes, com vistas a evitar rígidas formulações que pudessem levar à absolvição do acusado" (trad. livre), conforme citado por ROBINSON, D., op. cit., nota 1, p. 930. Digno de nota, o trabalho realizado pela ONG belga Avocats sans Frontières que, no sentido oposto, atua na defesa dos acusados de crimes contra a humanidade em países como Congo e Burundi.

${ }^{589}$ ROBINSON, Darryl. "The identity crisis of international criminal law", Leiden Journal of International Law, 21, 2008, p. 930. Também SCHABAS, W. "Sentencing by International Tribunals: A Human Rights Approach", Duke Journal of Comparative and International Law, 7, 1997, p. 515.

${ }^{590}$ Caso Edermovic, julgamento, Câmara de Apelação, TPII (IT-96-22-A), de 7 de outubro de 1997. § 6: "Your Honour, I had to do this. If I had refused, I would have been killed together with the victims. When I refused, they told me: 'If you are sorry for them, stand up, line up with them and we will kill you too'. I am not sorry for myself but for my family, my wife and son who then had nine months, and I could not refuse because then they would have killed me. That is all I wish to add."

${ }^{591}$ Os equívocos desse caso são diversos, como, por exemplo, o entendimento de que faltavam provas da defesa de que ele estava cumprindo as ordens para substanciar seu estado de necessidade. Ainda que se tratasse de argumento da defesa, era do interesse da justiça que também esses fatos se comprovassem, ainda mais para beneficiar o réu que se declarou culpado e foi condenado apenas com base em seu depoimento. V. § 10 do caso Edermovic, supra: "Trial Chamber considered that these were insufficiently proven since the Appellant's testimony in this regard had not been corroborated by independent evidence".
} 
internacional. Isso porque o reconhecimento de culpa não deve permitir a restrição dos direitos do acusado, com base no art. 20 do Estatuto do TPII, bem como orienta a possível consideração de estado de necessidade, se não com base no direito costumeiro, com base nos princípios gerais de direito ${ }^{592}$. Essa orientação prevaleceu na redação do art. 31.1(d), reconhecendo o estado de necessidade ${ }^{593}$, não como elemento de redução de pena, como na decisão questionada, mas como fundamento para a exclusão de responsabilidade criminal.

O discurso ambíguo fica evidente quando nos deparamos com a afirmação de que, dentro do sistema nacional, é preferível deixar dez pessoas culpadas livres do que condenar uma pessoa inocente, quando vimos a doutrina do direito penal internacional pender justamente para o oposto, com o discurso de que o acusado possa "escapar da condenação" ou "escapar da responsabilidade" a menos que haja uma flexibilização dos princípios de inculpação e restrição dos princípios de exculpação ${ }^{594}$. A reflexão de ROBINSON coloca, ainda, mais alguns pontos de interrogação. Segundo ele, "a doutrina iliberal do direito penal internacional não chega com uma roupagem autoritária clássica (por exemplo, a de que os direitos individuais devem ser sacrificados para servir os interesses do Estado ou da sociedade). Mas a doutrina iliberal chega com uma roupagem liberal - a do liberalismo dos direitos humanos, e, portanto, são rapidamente aceitas e absorvidas no sistema" ${ }^{" 595}$. Uma forma de se confirmar esse tipo de pensamento é a defesa da punição em virtude da magnitude dos danos, brutalidade das condutas, massivas violações dos direitos humanos, como critério de justiça substancial em detrimento da formal, com o enviesado pensamento de que a justiça formal seria contra a defesa dos direitos humanos.

Valendo-nos do aprendizado trazido pela análise e funcionamento da Corte Interamericana de Direitos Humanos, a tendência expansiva também se nota, quando se confirma a erosão progressiva do "princípio da legalidade penal, o sobredimensionamento

\footnotetext{
${ }^{592}$ Opinião Separada e Dissidente, Juiz Cassese, Caso Edermovic, julgamento, Câmara de Apelação, TPII (IT96-22-A), de 7 de outubro de 1997.

${ }^{593}$ Art. 31.1 do ETPI: "Sem prejuízo de outros fundamentos para a exclusão de responsabilidade criminal previstos no presente Estatuto, não será considerada criminalmente responsável a pessoa que, no momento da prática de determinada conduta. (...)d) Tiver incorrido numa conduta que presumivelmente constitui crime da competência do Tribunal, em consequência de coação decorrente de uma ameaça iminente de morte ou ofensas corporais graves para si ou para outrem, e em que se veja compelida a atuar de forma necessária e razoável para evitar essa ameaça, desde que não tenha a intenção de causar um dano maior que aquele que se propunha evitar (...)".

${ }^{594}$ ROBINSON, Darryl. "The identity crisis (...)", op. cit., p. 930.

595 Idem, ibidem, p. 931 (trad. livre).
} 
dos direitos da vítima à custa da posição do acusado, o enfraquecimento da coisa julgada, a inflação de certos conceitos com grande força expressiva ou simbólica"596, especialmente utilizado para justificar derrogações de direitos do acusado para a realização dos direitos humanos ao largo do direito penal, na validação do brocardo atrocíssima licet iudici iura transgredi.

É notório o sentimento de injustiça quando ocorrem absolvições com base em normas processuais, tendo-se exemplos vindos dos tribunais internacionais ad hoc que, aplicando normas processuais, deixaram de agasalhar argumentos do direito substantivo. A esse respeito, a decisão do TPIR é-nos exemplar. A Câmara de Apelação do TPIR libertou um acusado proeminente de sua detenção provisória com base no seu direito consagrado a um julgamento expedito e que, pelo tempo decorrido desde sua prisão, estava sendo violado por um tribunal de direitos humanos. Essa decisão causou um efeito de perplexidade do governo ruandês, que, sob a perspectiva das vítimas, decidiu suspender qualquer colaboração com o tribunal, motivando a retratação da Câmara de Apelação ${ }^{597}$. Outros casos que nos rementem a semelhante reflexão refere-se ao Caso Kajelijeli ${ }^{598}$ e o Caso $\operatorname{Brdjanin}^{599}$, a respeito da tese da defesa de excluir a prova relevante, obtida por meios ilegais.

\subsubsection{Liberalismo e o DPI: justiça substantiva e assimetrias}

O liberalismo dos direitos humanos e do direito penal nasceram para proteger os indivíduos do Estado - em direito penal, para proteger o acusado e potenciais acusados da máquina punitiva, e em direitos humanos, para proteger as vítimas individuais das várias formas de maus-tratos do Estado. Deveríamos ver com muito mais preocupação a superação das barreiras de contenção colocadas para proteger o indivíduo frente o avanço do poder

\footnotetext{
596 MALARINO, Ezequiel. "Jurisprudencia Latinoamericana sobre Derecho Penal Internacional”. In: AMBOS, Kai; MALARINO, Ezequiel; ELSNER, Gisela (eds.), Jurisprudencia Latinoamericana sobre Derecho Penal Internacional, Montevideu: Konrad Adenauer, 2008, p. 448 (trad. livre).

597 Caso Barayagwiza, TPIR (ICTR-97-19-AR72), decisão do pedido do procurador para revisão ou reconsideração, $\S \S 34$ e 74, de 31 de março de 2000.

598 Caso Kajelijeli, TPIR (ICTR-98-44ㄴa-T), julgamento e sentença, $\S \S 208,320-324$, de $1^{\circ}$ de dezembro de 2003.

${ }^{599}$ Caso Brdjanin, TPII ( IT-99-36-T), decisão sobre a objeção da defesa contra a prova interceptada, parágrafo 61 , de 3 de outubro de 2003.
} 
punitivo estatal $^{600}$. Mas é notória a apropriação pelos direitos humanos do exercício do poder punitivo, com o direito penal a reboque, para maximizar a proteção da vítima. Desta forma, "o liberalismo dos direitos humanos produz um sistema de direito penal que é progressivamente autoritário no desrespeito na restrição dos princípios, correndo o risco de usar o acusado como objeto em um exercício didático mais do que o respeito pela autonomia e justiça" ${ }^{601}$.

Passagem de um renomado internacionalista revela o cerne da questão a respeito da justiça substancial:

\begin{abstract}
"Alguns advogados de defesa que atuam nos sistemas nacionais podem ficar escandalizados com a facilidade com que os juízes internacionais ampliaram as definições de crimes e de princípios gerais da responsabilidade criminal. Mas este autor não se sente muito espantado com isso, porque se um crime corresponde ou não ao escopo da justiça internacional pelos Tribunais ad hoc é fundamentalmente um problema jurisdicional. Mesmo se supormos, por amor à argumentação, como muitos acreditavam antes da decisão da jurisdição do Caso Tadic, não havia responsabilidade penal individual no direito internacional em conflito armado interno, a conduta de base de assassinato, tortura, estupro permaneceram crimes com base nos princípios gerais do direito. Um acusado pode questionar que o tribunal não tenha jurisdição baseado em certas interpretações de artigos legais a respeito, mas não pode dizer que ele ou ela não sabiam que o que estavam fazendo era errado" $" 602$ (grifo nosso).
\end{abstract}

Desta maneira, ainda que se afirme a presença da doutrina da estrita legalidade, as justificativas baseadas na justiça substancial tem sido frequentemente invocadas para superar lacunas do sistema.

\footnotetext{
${ }^{600}$ Conforme MALARINO, "Un derecho penal con diferentes carriles, uno para el derecho penal normal, otro para el derecho penal internacional o de los derechos humanos, se acerca peligrosamente a un derecho penal para enemigos. Para muchos tribunales nacionales y para la CIDH la protección penal de los derechos humanos pesa más que la protección de los derechos humanos frente al derecho penal. Y esta es una conclusión que cualquiera que realmente crea en las virtudes de un Estado de derecho puede más que lamentar". MALARINO, Ezequiel, "Jurisprudencia latinoamericana sobre derecho penal internacional”, op. cit., p. 448 (destaque no original).

${ }^{601}$ ROBINSON, Darryl. "The identity crisis (...)", op. cit., p. 931 (trad. livre).

${ }^{602}$ SHABAS, W. "Interpreting the Statutes of the Ad Hoc Tribunals". In: VOHRAH, L.C. (ed.), Man's Inhumanity to Man: Essays on international law in honour of Antonio Cassese, 2003, p. 887 (trad. livre). Uma decisão da Corte Europeia de Direitos Humanos, no Caso SW e CR contra Reino Unido, destacou que uma ofensa pode ser punível se ela for razoavelmente previsível e for consistente com a essência da ofensa. Assim, mesmo que não esteja exata a descrição da norma proibitiva penal, mas previsível e consistente, ela é válida (Apelação No. 47/1994/494/576), CEDH (1995), Série A, N. 335-B e C, §§ 36 e 34 respectivamente.
} 
FARIA COSTA faz uma análise do direito penal e suas origens apegadas aos atributos do território e do povo, e de como a justiça era um dos atributos da afirmação do Estado-Nação, passando pela repartição radical entre o direito penal e a religião e, posteriormente, da separação entre o direito penal e a moral. A lei, assim, em um determinado espaço, debaixo da tutela das leis penais geneticamente ligadas a esse, aplicada por um mesmo imperium, concretiza a justiça humana aplicada ali, com a validade e efemeridade das coisas frágeis dos homens. Paralelamente a esta justiça, nos lembra de outra justiça, que também aplica sanções, julgava, com todo o tempo etéreo para tanto, uma justiça sem tempo nem espaço, a justiça divina. Por sua informalidade, ela conjugava todas as diferenças, encontrando o ponto de equilíbrio entre duas forças anancásticas: "o impulso para a perenidade transcendental e a não menos forte pulsão para a comezinha observação do homem individual e da comunidade que ele é o outro em devir histórico - em um tempo e em um lugar"603. A falta de uma delimitação rigorosa do campo punitivo suscita dúvidas em um terreno que deveria primar pela certeza, uniformidade e segurança ${ }^{604}$, revelando a falta de um consenso sobre o que, afinal, se decide.

Encontramo-nos no vértice do que foi exposto por DELMAS-MARTY, enunciando o papel paradoxal da relação conflituosa entre direito penal e direitos humanos: um direito penal que, concomitantemente, protege e ameaça os direitos humanos, e de um direito humano que permite, concomitantemente, um enquadramento e uma extensão do direito penal ${ }^{605}$. Também PASTOR identifica a tendência geral do direito penal moderno, junto com os pactos de direitos humanos, reconhecendo a missão de estabelecer direitos fundamentais e garantis judiciais diante do poder penal público, ressaltando que no limite todos perseguem o mesmo objetivo: a vedação à arbitrariedade no desenvolvimento e aplicação do poder punitivo, cuja origem, respaldada internacionalmente, remonta à aparição do Estado constitucional moderno que, "desde finais do século XVIII foi levando a todas as organizações políticas as ideias penais do Iluminismo e do Racionalismo"606.

\footnotetext{
${ }^{603}$ FARIA COSTA, José. "A Globalização e o Direito Penal (ou o tributo da consonância ao elogio da incompletude". Globalização e Direito - Boletim da Faculdade de Direito, Studia Iuridica 73, Coimbra, 2003, p. 186. Ainda: "os sinais exteriores de delimitação não existem. O que provoca uma total similitude de horizontes em qualquer latitude ou longitude onde nos encontremos.”, p. 187.

${ }^{604}$ ZILLI, Marcos. "Punir or not punir? Qual é o verdadeiro dilema?”, Revista Anisita, vol. 9, p. 353.

${ }^{605}$ DELMAS-MARTY, M. "Postface: d'um paradoxe à l'autre". In: CARTUYVELS, Y. e outros. Les droits de l’homme bouclier ou épée du droit penal, Bruxelas, Bruylant, 2007, p. 615.

${ }^{606}$ PASTOR, Daniel. El poder penal internacional. Una aproximación jurídica crítica a los fundamentos del Estatuto de Roma. Barcelona: Atelier, 2006, p. 23 (trad. livre).
} 
O questionamento que se faz é o de se saber se o direito penal internacional é apenas o braço executivo dos direitos humanos e do direito humanitário, adotando a pena de prisão aos violadores como uma forma de compensação às vítimas ou se é um sistema de justiça criminal que respeita as precondições doutrinárias e fundamentais para a punição e estigmatização dos indivíduos, segundo os princípios do estado de direito ${ }^{607}$. Adotando-se o segundo, deve-se buscar a orientação dos princípios do direito penal nacional, em bases liberais, a essa nova perspectiva de aplicação dos atributos do poder punitivo em âmbito internacional, ao mesmo tempo que aprofundar a pesquisa que revele de forma mais explícita a relação do direito penal com os direitos humanos como conhecimentos que mutuamente se fortalecem, ao invés de, no limite, representarem o paradoxo tal como atualmente posto. Assim, uma nova forma de trabalhar diferentes pressupostos jurídicos, novos contornos doutrinários, novas capacidades devem corresponder aos novos desafios, e tanto a doutrina, quando cientistas sociais, criminologistas, internacionalistas, penalistas, devem abraçar novas formas de colaboração. E, ao se reconhecem como defensores dos direitos humanos, o que, em sua essência, acabam por defender, deveriam criar novas hipótese à hora de confrontar direitos humanos aparentemente colidentes (garantias x obrigações de punir).

Para a criminologia anglo-saxã, existem claros sinais de que ela começa a desenvolver-se além de suas preocupações históricas com os crimes nacionais, ainda que a perspectiva de uma criminologia internacional esteja ainda num estágio formativo, a ser amadurecido com práticas comparadas ${ }^{608}$. Na reflexão do que é o crime, antes mesmo de passar a entender suas causas, relembra ROBERTS de que o método criminológico não sustentaria o conceito de "crime internacional", por exemplo, em relação ao terrorismo. Se, por um lado, um comportamento pode ser considerado terrorista, por outro, pode ser associado a movimentos de libertação nacional, como faz recordar os casos de Nelson Mandela e Martin McGuiness ${ }^{609}$, com suas sortes completamente revolvidas, tornando-se lideranças reabilitadas.

\footnotetext{
${ }^{607}$ ROBINSON, Darryl. Op. cit., p. 932.

${ }^{608}$ ROBERTS, Paul; MCMILLAN, Nesam. "For criminology in International Criminal Justice", Journal of International Criminal Justice, 1, 2003, 318. VAGG, J. "Context and Linkage: reflections on comparative research and 'internacionalism' in criminology”, 33, British Journal of Criminology, 1993, 541.

${ }^{609}$ Antigo membro do IRA (Exército Revolucionário Irlandês), tornou-se Ministro da Educação da Irlanda do Norte, v. O’REILLY, Emily. "Disarming Martin McGuiness", The Observer, 6 de fevereiro de 2000.
} 
A criminologia dos anos 60 e $70^{610}$ forneceu marcos teóricos para o progresso da definição da criminalização como um processo ativo de construção social e influência constante política. Desta forma, pode-se avaliar o crime com relação à sua formação, conteúdo, aplicação e censura, de uma perspectiva variada de análise, também como escolha política $^{611}$. Examinando os aspectos relacionados aos fatores precursores do crime: social, econômico e cultural, pesquisadores dessa tendência científica propõe a existência de ambientes inerentemente "criminógenos", produtores da cultura da criminalidade. Indo além dessa metodologia, aplicada ao contexto da justiça penal internacional, ROBERTS e MCMILLAN relacionam essa análise à proliferação internacional dos mercados ilegais ${ }^{612}$, como função da globalização do capitalismo. Nessa perspectiva, os mercados ilegais - por exemplo, da produção e do tráfico de drogas, prostituição, tráfico de pessoas - vicejam em Estados com condições econômicas e sociais desfavoráveis, confirmando a relação de crime e assimetria estrutural do comércio internacional e sistema financeiro. Em sua opinião, seria equivocado, diante dessa realidade, promover a distinção entre crimes nacionais e globais, isso porque os mercados tornaram-se globais, na era da globalização. Assim, transplantando essa reflexão para o contexto do direito internacional humanitário, as zonas de guerra, geograficamente localizadas, são ambientes sociais criminógenos por excelência, visto que os senhores da guerra (warlords) ou organizações criminosas expandem suas operações preenchendo os vácuos de poder gerado pela ruptura dos sistemas normalizados de manutenção da ordem e de polícia civil. Os autores britânicos sustentam que os Estados falidos ou à beira da falência são ímãs para a ocorrência de crimes internacionais, levados a este contexto devido à expectativa de que nesses locais o mercado negro floresça, com facilidade de recrutamento de membros dentre uma população desmobilizada, e de uma administração pública já adepta às práticas da corrupção ${ }^{613}$. A criminalização, como uma ação política, acaba por fortalecer aqueles que estão em posição de determinar o que se

${ }^{610}$ DOWNES, D.; ROCK, P. Understanding deviance: a guide to the sociology of crime and rule breaking. Oxford: Oxford University Press, $3^{\mathrm{a}}$ ed., 1998.

${ }^{611}$ Como se sabe, TOBIAS BARRETO, um dos juristas mais influentes do século XIX, afirmou que o conceito de pena, juntamente com seu correlato, o crime, não é propriamente jurídico, mas político. Menores e loucos. Fundamentos sobre o direito de punir. Edições do Estado do Sergipe, 1926. Também em direito internacional, v. DAVID, Eric. "Les valeurs, politiques et objectif du droi penal international à l'heure de la mondialisation". International Criminal Law: Quo Vadis, AIDP, no 19, 2004, p. 157.

612 ROBERTS e MCMILLAN, "For criminology...", op. cit., p. 323.

${ }^{613}$ Idem, ibidem, p. 324. 
considera por "crime", assim como quem são aqueles que tem condições de "enviar a polícia" ${ }^{\prime 614}$.

Condições especiais, contextos criminógenos, típicos de contextos que favorecem uma criminalidade também expansiva, choca-se com as aspirações de uma justiça universal, de alcance global, sendo o TPI o maior símbolo dessa realização da comunidade internacional, contribuindo para que sociólogos apontem a existência inescapável de impactos assimétricos em relação aos efeitos da globalização, colocando a importante reflexão de se a "comunidade internacional" é suficientemente ampla e profunda, em seus pressupostos comuns, para reivindicar a legitimidade da penalidade internacional $?^{615}$ Nesse caso, a relevância de um sistema penal internacional teria uma função simbólica, num processo de formação a longo prazo, superadas as dificuldades e adversidades que pudessem aparecer no caminho, de um alinhamento em apoio às medidas coercitivas previstas. Em todo caso, pode-se dizer que inexiste um sentimento em torno a uma comunidade global penal diante das diferenças dos direitos penais nacionais, para além do que se considera em todas as culturas, um crime. Se, por exemplo, todas os sistemas criminalizam a conduta de assassinato ou estupro, as defesas possíveis em cada sistema, por meio das excludentes de punibilidade ou antijuridicidade, variam fundamentalmente. Além disso, o escopo das proibições criminais, os modelos de prova, as proteções processuais aos acusados, vítimas ou testemunhas, tipo de sanções e sua gradação, revela a disparidade existente ainda hoje.

Para o desenvolvimento de uma sensibilidade penal global, deve-se ter em conta essas distinções, e que a canalização de uma cultura penal transnacional não se obtém a curto prazo, por meio das técnicas legislativas, de cunho formalista, e que prescinde da propagação dos ideais e normas ocidentais, mas também do ceticismo paralisante do relativismo cultural extremo, nas contundentes palavras de ROBERTS e MCMILLAN ${ }^{616}$.

\footnotetext{
$614 \mathrm{Na}$ expressão de KOSKENNIEMI, Martii. KOSKENNIEMI, Martii. "Hersch Lauterpacht and the Development of International Criminal Law", op. cit., p. 825.

615 ROBERTS e MCMILLAN, "For criminology...”, op. cit., p. 329. SIMMA, B.; PAULUS, A.L. "The international community: facing the challenge of globalization", 9, European Journal of International Law, 1998 , pp. 266 ss.

616 ROBERTS e MCMILLAN, “For criminology...”, op. cit., p. 330
} 


\subsubsection{Responsabilidade individual v. Contexto Sócio-Político}

$\mathrm{O}$ fato de se consagrar a responsabilidade individual dentro do direito penal internacional pode ter um efeito perverso de tirar o foco do elemento sistêmico, associativo, geopolítico e socioeconômico por trás da criminalidade internacional ${ }^{617}$. A comunidade internacional tem constantemente vacilado entre a responsabilidade coletiva (particularmente de Estados) e a individual, cada uma buscando corresponder ao que a outra deixava de atender, observando SIMPSON ${ }^{618}$ que a esse respeito existe uma "negociação perpétua" entre as perspectivas individualistas e coletivas na atribuição de responsabilidade por crimes internacionais. A fase inicial, referente ao período posterior à I Guerra Mundial, conhecida como "culpe a coletividade" (blaming the collective) foi bastante questionada diante da consequência política que criticou o sofrimento de toda uma população pelos erros de um grupo específico de criminosos. Esse conceito, da responsabilidade individualizada ao invés de vitimizar toda uma população e o risco de fazer surgir o populismo revanchista, motivou o julgamento de Nuremberg, que serviu inclusive como forma para apagar do povo alemão as marcas da culpa coletiva, para ficarmos nos exemplos extremos de uma e outra tendência.

O adensamento de contribuições para a execução de crimes em massa, tanto por parte de organizações criminosas quanto por organizações lícitas, envolve os instrumentos clássicos da criminologia (métodos, meios e oportunidades) que determinam a forma de envolvimento dos indivíduos nos atos criminosos: segundo o desenvolvimento dos processos de autorização, neutralização, racionalização e desumanização. Nesse sentido, a culpabilidade individual representa um papel menos relevante do que as condições de realização sistêmica do crime, sugerindo, por fim, que a responsabilização criminal individual apenas cria uma reticente figura e que nunca será suficiente para captar a essência da criminalidade, que, em última instância, é o que se quer combater. Quando falamos em criminalidade sistêmica há que se considerar que "dentro destas organizações os indivíduos parecem ser capazes de cometer crimes que eles sequer cogitariam cometer se estivessem

617 ROBERTS e MCMILLAN, “For criminology...”, op. cit., p. 331.

618 SIMPSON, G. "Men and abstract entities: individual responsibility and collective guilt in international criminal law". In: NOELLKAEMPER, A; VAN DER WILT, H. (eds.). System Criminality in International Law. Cambridge: Cambridge Univ. Press, 2009, pp.69-100. 
agindo sozinhos, assim como eles não seriam capazes fisicamente de cometê-los por si mesmos"619.

Tanto a atribuição de responsabilidade criminal pela função de comando militar (quando não conseguirem evitar ou reprimir as violações do direito internacional humanitário) por seus subordinados, ou a aplicação da doutrina da empresa coletiva criminal (joint criminal enterprise), larga e acriticamente utilizada pelo TPII ${ }^{620}$, não dão conta de corretamente enfrentar o problema. As respostas coletivas certamente não passam pela responsabilidade criminal coletiva, e a forma de responsabilidade acaba tendo um efeito declaratório e simbólico.

Por outro lado, entende-se que a responsabilização criminal individual de alguns acusados auxilia na capacidade de promover a reconciliação dos distintos grupos em conflito, ao passo que a atribuição da responsabilidade coletiva aumentaria a estigmatização e a conflituosidade entre os grupos. Nesse sentido, o Conselho de Segurança da ONU, ao determinar a criação do TPIR, entendeu que se for negligenciada a possibilidade legal de atribuição de responsabilidade individual, levar-se-ia à percepção de que grupos étnicos ou religiosos, em particular, seriam coletivamente responsáveis, prejudicando as chances de reconciliação entre os grupos. A atribuição de responsabilidade individual, objetivo do Tribunal, "contribuiria para o processo de reconciliação nacional”621.

619 NOLLKAEMPER, André; VAN DER WILT, Harmen. "System criminality in international law: conclusions and outlook". Janeiro, 2009, p. 339.

${ }^{620}$ Segundo NOLLKAMEPER e VAN DER WILT, considerando que o conceito não passou do nível invidiual e apenas pode conectar coletividades nas quais os indivíduos participaram, os autores expressam sua preocupação do uso acrítico e alargado do conceito pela jurisprudência do TPII: "the problem with the doctrine is that it serves as a cloak, covering and uniting participants acting at different organizational levels, without much heed being paid to the actual contributions of those participants and their mutual synergy. In their enthusiastic reception of JCE (joint criminal enterprise doctrine), prosecutors and courts may easily lose sight of the legal pedigree and predecessors from which the doctrine has emerged". Op. cit., p. 341.

${ }^{621}$ Res. 955, ONU, CS, Doc. S/Res/955, de 8 de novembro de 1994, (trad. livre). Também o Caso Nikolic, TPII (IT-02-60/1-S), sentença, $\$ \$ 59$ e 106, de 2 de dezembro de 2003; presidente do TPII, "if responsibility for the appalling crimes perpetrated in the former Yugoslavia is not attributed to individuals, then who le ethnic and religious groups will be held accountable for these crimes and branded as criminals. In other words, 'collective responsibility' - a primitive and archaic concept - will gain the upper hand; eventual whole groups will be held guilty of massacres, torture, rape, ethnic cleansing, the wanton destruction of cities and villages". Annual Report of the International Tribunal for the Prosecution of Persons Responsible for Serious Violations of International Humanitarian Law Committed in the Territory of the Former Yugoslavia Since 1991, § 16, submetido ao Conselho de Segurança e à Assembleia Geral da ONU, UN Doc. A/49/342, 29 de Agosto de 1994. 


\subsubsection{Efeito preventivo dos julgamentos internacionais}

Segundo o ex-presidente do TPI, o juiz KIRSH, "o TPI foi criado para romper o ciclo vicioso dos crimes, da impunidade e do conflito. Foi criado para contribuir com a justiça e a prevenção de crimes e, portanto, com a paz e a segurança". Essa perspectiva também é confirmada pelo escritório do procurador do tribunal (OTP), sendo que para ele, o efeito preventivo não se limita à situação sob investigação, mas estende-se para todos os estados Parte e reverbera em todo o mundo.

Entretanto, há um geral descrédito do efeito preventivo, visto que ofensores inserem-se num contexto institucional político cujo endereçamento escapa o âmbito do direito penal. Os crimes são cometidos em geral sob a guarida, proteção e orientação de uma organização articulada, sendo que os efeitos de prevenção e ressocialização tendem a não atingir o espírito do ofensor, imerso que se encontra numa contexto mais propenso à ruptura com o Estado de Direito do que ao cumprimento de seus preceitos. ROTH-ARRIAZA ${ }^{622}$ pondera que estas características não são nem pessoais nem aberracionais, elas são deliberadamente inculcadas num dado contexto institucional, como parte de uma missão maior, por exemplo, segurança ou resistência coletiva, como formas de manutenção do convencimento e adesão às práticas fora das regras Estado de Direito. O fato de grandes impunidades de fato e de direito aumenta a percepção de que o indivíduo, com já reduzida autonomia pessoal, atuando como elemento de uma engrenagem, tem mais a ganhar do que a perder se corresponder à expectativa do coletivo criminal. Essas ponderações sobre os efeitos da pena, preventivos e retributivos, especialmente, foram expressas pelo TPII, especialmente nos casos Celibici e Dedalic ${ }^{623}$, embora com mais vigor sob o argumento de luta contra a impunidade e busca de justiça e paz para a comunidade internacional.

Dificilmente podemos concluir que os julgamentos dos crimes internacionais tiveram um efeito preventivo sobre futuros crimes da mesma gravidade, inclusive pela própria dificuldade de se processar crimes em escala mundial. Assim, para $\mathrm{MERON}^{624}$, a

${ }^{622}$ ROHT-ARRIAZA, Naomi (ed.). Impunity and Human Rights in International Law and Practice, Oxford: Oxford Un. Press, 1995, pp. 14 e 15. A autora cita as hierarquias militares e políticas como exemplos de descumprimentos legais com base nas disposições sobre obediência hierárquica.

${ }^{623}$ TPII, Câmara de Apelação, Dedalic e outros, decisão de 20 de fevereiro de 2001, IT-96-21-A, § 799 ss.

${ }^{624}$ MERON, Theodore. "From Nuremberg to the Hague", 149, Military Law Review, 107, 1995, p. 110. 
comunidade internacional deveria fortalecer a possibilidade de punição pelo encorajamento do processamento pelos tribunais locais, tribunais ad hoc ou pelo TPI. No caso do TPI, ainda que não se consiga evitar o cometimento de crimes de genocídio ou contra a humanidade em conflitos em curso, os julgamentos acabam por reforçar a norma internacional aplicável e, com isso, contribuir para uma, ainda que distante, fixação de uma cultura política que considera as condutas atrozes contra os direitos humanos inaceitáveis. Para MERON, esse efeito instrumental falha devido ao fato de que os julgamentos por tais crimes são tão excepcionais que os criminosos não acreditam que serão julgados e punidos.

A abordagem dos efeitos preventivos, na visão de WIPPMAN ${ }^{625}$ contém diversos problemas. A começar pela própria experiência de Nuremberg, quando logo após sua conclusão, o entusiasmo dos Aliados pela julgamento criminal desvaneceu rapidamente, isso porque vários oficiais criminosos alemães eram muito valiosos para serem processados, além do que muitos outros escaparam ou não foram processados, a ponto de se afirmar ironicamente que um dos princípios implícitos de Nuremberg e Tóquio era o de que julgamentos largamente publicizados de alguns poucos líderes foram responsáveis por tudo o que se praticou, num processo de criminalidade em que centenas de milhares de pessoas foram, de fato, culpáveis, de uma forma ou de outra ${ }^{626}$.

A prevenção é definida como a "capacidade de um sistema legal desencorajar o evitar certas condutas por meio de ameaças de punição ou outra expressão de desaprovação"627. Com base nisso, os potenciais autores ponderariam a ameaça da pena no cálculo da vantagem do crime, dos resultados advindos, da possibilidade de conseguir escapar, e que essa percepção, decorrente de uma ponderação racional, conduziria à preferência por não cometer o crime. Entretanto, o contexto nos quais ocorrem os crimes de máxima atrocidade, envolvendo incitações apaixonadas, ódios profundos e uma

\footnotetext{
${ }^{625}$ WIPPMAN, David. “Atrocities, deterrence, and the limits of International Justice”. Fordahm International Law Journal, vol. 23, 2, 1999, 480.

${ }^{626}$ Conforme ROBERTS, Adam. The Laws of War: problems of implementation in contemporary conflicts, 6 , Duke J. Comp. and Intl. Law, 11, 1995, pp. 26-26.

${ }^{627}$ AKHAVAN, Payan. “Justice in the Hague, Peace in the Former Yugoslavia?”, 20, Human Rights Quarterly, 737, 1999,p. 741. Também AKHAVAN, Payan. "Beyond Impunity: Can International Criminal Justice Prevent Future Attrocities?”, The American Journal of International Law, 95, 2001, pp. 7-31.
} 
racionalidade desviada do respeito ao outro ${ }^{628}$, somado ao fato da raridade com que os julgamentos ocorrem, indica a pouca eficiência desta perspectiva.

É difícil imaginar que diante das categorias dos crimes contra a humanidade, genocídio e demais crimes de execução massiva, o modelo da prevenção se ajuste. Diante da banalidade do mal, o discernimento também se embrutece, chegando-se inclusive a afirmar que existe pouca liberdade de ação ${ }^{629}$, num recurso linguístico exagerado - há a consciência, mas não existe incentivo para que o indivíduo não pratique o crime, resultado no pouco poder de a norma exercer um efeito preventivo.

Dificilmente conseguimos sustentar que nesse cálculo o efeito preventivo dos julgamentos das cortes internacionais exerceria o poder de influenciar a opção pelo não recurso à violência. Por outro lado, DAMASKAS entende ser mais apropriado, para esse efeito, enfatizar mais o papel da persuasão do que na prevenção em si. Para além dos efeitos de suas decisões, as cortes devem encarar que os efeitos denunciatórios de suas decisões fortalecem o senso de responsabilização pelos crimes internacionais por meio da exposição e estigmatização destas formas extremas de desumanidade. Assim, seriam exitosas as experiências da cortes internacionais nesse aspecto, realçando o respeito cada vez maior pelas normas de direito internacional humanitário. Entretanto, adverte a autora que existe uma condição necessária para o sucesso do papel pedagógico das decisões da corte: que ela seja percebida por seus jurisdicionados como uma autoridade legítima. Na ausência de um poder coercitivo internacional, sua legitimidade firma-se quase inteiramente na qualidade de suas decisões e de seus procedimentos ${ }^{630}$

Tanto os resultados dos tribunais para a ex-Iugoslávia quanto para Ruanda representaram uma centelha diante da destruição provocada. A inabilidade de processar um

\footnotetext{
${ }^{628}$ Mesmo no caso dos bósnios e sérvios, era amplo o conhecimento das Convenções de Genebra sobre a proteção de civis em tempos de guerra. Entretanto, esse conhecimento que poderia representar um limite de ação durante o conflito não se sustentou porque foram superadas pelo ódio e paixões nacionalistas. Conforme afirma o relatório da Cruz Vermelha, "the rules of war have not been repudiated in the minds of those who have experienced the conflict. They were overwhelmed in large part by the rules on the ground, which created powerful exceptions, amendments or suspensions whereby millions of civilians joined the front lines". International Committee for the Red Cross (ICRC), Country Report on Bosnia-Herzegovina, item iv (disponível em https://www.icrc.org/eng/assets/files/other/bosnia.pdf, Acesso dia 02.02.2015)

${ }^{629}$ TALLGREN, I. "The sensibility and sense of international criminal law", EIJIL, 12, 2002.

${ }^{630}$ TYLER, Tom R. Why people obey the law, 1990, HASSEMER, Winfied. Warum und zu Wlschem End Strafen Wir?, 30, Zeitschrift für Rechtspolitik, 316, 1997, p. 321, citado por DAMASKAS, Mirjan R. "What is the point of international criminal justice?", op. cit., p. 345.
} 
número relevante de suspeitos dos crimes ou dos altos escalões responsáveis pela limpeza étnica manda, no mínimo, uma mensagem confusa àqueles possivelmente inclinados a repetir tal experiência. O governo de Ruanda, seguindo essa mesma experiência, viu-se obrigado a "registar uma falta de confiança no Tribunal", questionando abertamente os efeitos preventivos do trabalho do Tribunal, sugerindo, inclusive, que diante de tamanha ineficiência, uma corte permanente poderia resultar numa "versão permanente de um fracasso temporário"631. O desânimo com relação ao efeito preventivo levou o primeiro procurador do TPII, Richard Goldstone ${ }^{632}$, a afirmar que é “desesperançosamente idealístico" afirmar que a justiça criminal internacional exerça um efeito preventivo efetivo. Também no caso Tadic ${ }^{633}$, a Câmara de Apelação afirmou que à prevenção não deve ser dada uma "proeminência indevida". Mas para AKHAVAN, que atuou na Procuradoria do TPII, a contribuição do tribunal deve ser saudada, reforçando a posição do dever de processar e atribuir responsabilidade criminal como objetivos de um novo realismo político:

\begin{abstract}
"O atraente espetáculo de drama nas salas de audiência, que desenha a escuridão contra as forças da luz e reduz o mundo a uma narrativa controlável, pode levar a justiça criminal internacional a se tornar um exercício de auto-afirmação moral e um substituto para um autêntico compromisso e solução. A justiça pós-moderna sem um correspondente compromisso de recursos militares, políticos e econômicos dissolve significativamente a mensagem sobre o dever de atribuir responsabilidades e prejudica a viabilidade de prevenir crimes no longo prazo" $" 634$.
\end{abstract}

Chegamos a pensar que os benefícios das justiças praticadas pelos tribunais internacionais podem satisfazer mais os espectadores, especialmente aqueles localizados no ocidente e suas práticas de justiça ocidental, do que exatamente as sociedades que

\footnotetext{
${ }^{631}$ Declaração de Joseph Mutaboba na AG ONU, 9 de novembro de 1999 (trad. livre).

${ }^{632}$ GOLDSTONE, Richard. Carta ao Editor, Wall St. Journal, 7 de julho de 2000, A13.

${ }^{633}$ Caso Tadic, TPII (IT-94-1-A e IT-94-Abis), julgamento da apelação, §, 48, 26 de janeiro de 2000 (trad. livre).

${ }^{634}$ AKHAVAN, Payan. "Beyond Impunity: Can International Criminal Justice Prevent Future Attrocities?", The American Journal of International Law, 95, 2001, p. 7. No original, para confirmação da tradução nossa, em vista da adaptação que consideramos necessária: "the attractive spectacle of courtroom drama, which pits darkness against the forces of light and reduces the world to a manageable narrative, could lead international criminal justice to become an exercise in moral self-affirmation and a substitute for genuine commitment and resolve. Postmortem justice without a corresponding commitment of military, political, and economic resources significantly dilutes the message of accountability and undermines its long-term viability in preventing crimes."
} 
vivenciaram as experiências da guerra. Ao final dos anos 40 do século passado, não havia mais apoio para os julgamentos dos industriais alemães que apoiaram o nazismo e os procedimentos contra os militares de alto ranking eram mal vistos, em vista de sentimentos mistos envolvendo medo do comunismo, germanofilia, resquícios de antissemitismo, a ponto de os alemães se virem mais como vítimas do que como perpetradores ${ }^{635}$. Também no caso da ex-Iugoslávia, o tribunal mereceu pouca credibilidade da população na verdade difundida em suas decisões pela falha em processar criminosos de guerra da região, ao mesmo tempo por não ter havido qualquer sanção ao bombardeio em Srebrenia.

Assim é que as transformações de regimes autoritários em democracias mais ou menos liberais no leste europeu, América do Sul e África do Sul sugerem um entendimento bastante complexo dos efeitos e do papel dos julgamentos criminais não apenas em relação à punições e ao papel retributivo, menos ainda preventivo, mas em grande medida em relação ao conceito e resultados dos processos ligados à "justiça de transição": "às vezes, realizar um julgamento final no sentido religioso, uma realização que iria em último caso permitir que o Estado atue como um agente moral" ${ }^{636}$, recorrendo-se aos efeitos simbólicos de um julgamento criminal na construção de uma comunidade moral de indivíduos. Nesse sentido, KOSKENNIEMI defende que em certos casos, na busca de atender aos efeitos simbólicos, criando um efeito na comunidade, a lei penal não deve ser aplicada a todos, e seria suficiente que alguns julgamentos com bastante publicidade fossem levados a cabo, demonstrando a verdade em relação ao passado, e que as vítimas pudessem apresentar sua versão e seu relato, para se reafirmar os princípios morais desta comunidade. O processo no direito penal internacional acaba sendo seletivo até por questões logísticas (100.000 suspeitos de guerra residentes nas zonas ocupadas da Alemanha Ocidental em 1946, 120.000 detentos nas prisões ruandesas em 2001).

Assim, a afirmação da verdade e a indicação de um novo recomeço indicando as violações como iniquidades que não podem voltar a ocorrer, os "show trials" ou julgamentos espetáculo podem ser em certa medida suficientes, especialmente se forem acompanhados de outras medidas como abertura de arquivos, medidas administrativas e reformas

\footnotetext{
${ }^{635}$ Sobre vitimização coletiva. V. BLOXHAM, D. Genocide on Trial, War Crimes Trials and the Formation of Holocaus History and Memory, Tese de doutorado, Southampton, 2001, 38-56.

${ }^{636}$ BORNEMAN, J. Settling accounts, violence, justice and accountability in postsocialist Europe, 1997, p. 23, citado por KOSKENNIEMI, Martii. "Between impunity and show trials", Max Plank UNYB, 6, 2002, p. 10.
} 
institucionais, comissões da verdade, punições disciplinares ou desqualificações do serviço público, indenizações. E é nisso que reside um ruído entre a justiça das cortes internacionais e as perspectivas da justiça de transição. Embora pela perspectiva da justiça de transição possa se aceitar os julgamentos espetáculos, julgando apenas os principais líderes políticos ou executores do regime de exceção, essa perspectiva seletiva e política não pode operar no plano internacional. Afirma KOSKENNIEMI, que quando julgamentos são conduzidos por um procurador estrangeiro, diante de juízes estrangeiros, não há uma moral da comunidade sendo afirmada além de uma fictícia "comunidade internacional" auto-complacente, no qual "toda falha de processar é um escândalo, todo julgamento muito pouco para restaurar a dignidade das vítimas, e nenhum simbolismo persuasivo é suficiente para justificar o desenho tênue da linha entre o passado e o futuro"637.

Para AKHAVAN, uma realidade de violência descontrolada deixa pouco espaço para um romantismo judicial e ainda menos para um triunfalismo moral. Ainda assim, para se conseguir uma prevenção efetiva contra uma cultura enraizada de impunidade, precisa-se de muito mais do que tribunais internacionais ad hoc, ou julgamentos nacionais aqui e ali. Esses julgamentos, procurando veicular uma moral e um direito nobre, mas que não se consegue firmar como prática efetiva e normal dos países, não deixa de dar a impressão de se estar fazendo uso do acusado como objeto, para além de sua individualidade, mas pelo poder do seu símbolo. A luta contra a impunidade afirma-se como uma luta seletiva, em Estados fracos, com acusações simbólicas e resultados sistêmicos insubsistentes ${ }^{638}$. Outra ponderação que dificulta o trabalho imparcial do TPI é o entendimento de que diante de violações de excepcional magnitude e gravidade, há estudos que indicam que quanto mais grave o crime, maior a pressão da opinião pública por uma condenação e maior é a probabilidade de se perceber o acusado como uma pessoa responsável pelo crime ${ }^{639}$.

Mas a pressão pública não pode transformar os julgamentos em "show trials" no sentido estalinista do termo, quando os julgamentos reclamam automaticamente as

\footnotetext{
${ }^{637}$ KOSKENNIEMI, Martii. "Between impunity and show trials", Max Plank UNYB, 6, 2002, p. 11.

${ }^{638}$ Conforme DAMASKAS, "powerful actors in the international arena are in the position to ignore the demands of international courts, and the sword of justice tends to be used most against individuals from states that occupy a lowly place in the de facto existing hierarchy of states. Absent outside pressures by well-endowed nations, even weak states can defy the mandates of international courts with impunity". DAMASKAS, Mirjian R., "What is the point of international criminal justice", op. cit., p. 330.

${ }^{639}$ Conforme ROBBENNOLT, J. K. “Outcome severity and judgments of 'reponsibility': a meta-anlytical review”, 30, Journal of Applied Social Psychology 2575, 2000.
} 
acusações do procurador, relembrando o constrangimento dos juízes ocidentais em Nuremberg, quando os juízes soviéticos no início do julgamento brindaram à sorte do julgamento, bradando: "que todos sejam enforcados!" 640

Conforme KOSKENNIEMI, qualquer coisa que seja mais do que verdade, lições, catarse, reconciliação, dependerá de como o tribunal será capaz de lidar com um paradoxo construído e no instalado no âmago de seu mister ${ }^{641}$. Assim como a Corte Internacional de Justiça, o TPI pode aportar importantes contribuições no esclarecimento e desenvolvimento do direito internacional e, modestamente, para a prevenção geral ${ }^{642}$, mas dificilmente pode-se antever um grande impacto na incidência das violações ao direito internacional humanitário.

\subsection{Fraturas Expostas do DPI}

\subsubsection{Direito Universal vs. Moral Universal}

Necessário ponderar, a essa altura do avanço dos trabalhos, a existência de um direito que se lança no universo propagando uma moral universal, quando os valores ainda são relativos ao mesmo tempo que diante dos crimes graves de direito internacional sabe-se que não podem ficar impunes. Considera-se como pressuposto que os atos são desumanos e que com isso estariam de acordo todas as sociedades do mundo. Entretanto, caso esses valores não sejam compartilhados pela coletividade de sociedades, ou se esses valores não forem capaz de demonstrar sua autoridade em relação aos indivíduos que eventualmente se organizem à sua margem, possa se fundamentar a fragilidade da justiça criminal internacional. Assim, se esse mínimo denominador comum moral não for universal, válidos e eficazes independente do lugar ou tempo, então, a teoria dos "direitos humanos não seria mais do que um costume étnico do Oeste, e seu braço penal não seria mais do que uma

\footnotetext{
640 Procurador soviético Andrei Vyshnsky, conforme relatado por TAYLOR, Telford. The anathomy of Nuremberg Trials. A personal memoire, Nova Iorque, 1992, p. 211.

${ }^{641}$ KOSKENNIEMI, Martii. "Between impunity and show trials", Max Plank UNYB, 6, 2002, p. 35.

${ }^{642}$ WIPPMAN, D. “Atrocities...”, op. cit., p. 484.
} 
tentativa das elites ocidentais de impor sua moral e seus ideais a outras partes do mundo"643. Os sérvios consideram o julgamento do TPII tendencioso, ainda que para a nossa razão qualquer ação semelhante ao que ocorreu contra os bósnios fosse injustificável ${ }^{644}$ - mas isso não faz o julgamento dos sérvios mais justo.

De uma forma originária, os elementos para se exercer o direito de punir estão presentes num contexto local, diante da realidade jurídica em que estes ocorreram. Dificilmente consegue-se exportar princípios inerentes de uma sociedade nos exatos termos a outra, tanto princípios particulares, como o da insignificância, da liberdade de associação ou de expressão, quanto mais gerais, como a da legalidade. Idealmente, a justiça criminal internacional será adaptada aos contornos da experiência comunitária, e às sensibilidades da moral local, empreendendo o que se chamou de fragmentação do direito penal internacional, cujo desafio é a manutenção de uma coerência sistêmica.

A esse respeito, DELMAS-MARTY sugere que o direito penal internacional esteja limitado a articular os princípios orientadores para o exercício do poder punitivo dos crimes de sua competência, buscando mais harmonizar do que unificar todos os sistemas jurídicos mundiais, e que nos parece bastante razoável se estamos, de fato, lidando com sistemas valorativos distintos. Em abono disso, a prioridade das cortes penais internacionais deveria ser o estabelecimento de linhas eficientes de comunicação com o público local e de os juízes empreenderem uma tarefa potente de esclarecerem, cada vez que se afastam da norma local e das práticas consideradas adequadas ou justas no sistema local, suas motivações amplamente respaldadas nos aspectos garantistas do exercício de qualquer poder punitivo $^{645}$. $\mathrm{O}$ fato de a jurisdição do TPI ser complementar em relação às jurisdições locais demonstra a precedência dos tribunais locais, tanto quanto das suas leis, como fonte do direito do $\mathrm{TPI}^{646}$.

\footnotetext{
${ }^{643}$ Conforme DAMASKAS, op. cit., p. 347. No original: "than human rights is no more than na ethnic custom of the West, and its penal branch no more than an attempt of the Western elites to impose their moral ideals on other parts of the world".

${ }^{644}$ Segundo o Ministro da Justiça iugoslavo, Zoran Knezevic, o julgamento do TPII foi tendencioso contra os sérvios porque, "como regra, estes tipos de instituições [como os tribunais de guerra] são políticas, não legais", citado por BROWN, Justin. "World facing up to atrocities?", Christian Science Monitor, 16 de fevereiro de 1999, p. 6 (trad. livre).

${ }^{645}$ DAMASKAS, Mirjan R. Op. cit., p. 349.

${ }^{646}$ NOUWEN, Sarah; LEWIS, Dustin. "Jurisdictional Arrangements and International Criminal Procedure". Legal Studies Research Paper Series, Univ. Cambridge, Paper n 50/2001, novembro de 2011, p. 12-15.
} 
SIEBER $^{647}$ chama a atenção mais para as diferenças do que para o fato de estarem harmonizadas, em suficiente grau de precisão, os conceitos de crimes como os crimes contra a humanidade, procurando uma racionalidade fundamental que justifique mas também preveja o resultado de um começo de harmonização jurídica. Para o autor, a harmonização jurídica em termos penais passa pela conformação de duas ordens de força: de uma lado, na interação entre os interesses na preservação de sua soberania e suas características únicas em termos de história, cultura e econômicos (ou seja, numa perspectiva conservadora, de manutenção destes padrões) e de outro, as forças harmonizantes: do reconhecimento cada vez mais amplo das posições legais comuns, do crescente interesse pela segurança internacional (colocado em risco pelos crimes transnacionais), a influência crescente de autores além dos países na área de política criminal e a crescente cooperação internacional baseada em novos instrumentos de aproximação legal. A harmonização passa pela convergência de discursos relativos à proteção universal dos direitos humanos e liberdades econômicas ${ }^{648}$, à ideia de efetivação dessa proteção por meio do TPI e outros órgãos similares, às vezes aumentando a incidência e o escopo da norma penal, às vezes restringindo-o.

A resposta individualista ao crime internacional desconsidera que tendo o fato ocorrido de forma sistêmica, massiva, elementos contextuais fazem mais diferença do que se imagina e a prevenção desses elementos não ocorre ocasionalmente, pontualmente, mas principalmente cultural e economicamente, quando se conseguem visualizar condições de convivência mútua, sem a necessidade de exterminar ou violentar os seus vizinhos, que acabam sendo as maiores vítimas das rivalidades que culminam nos crimes internacionais. Assim, a percepção da solução individual, por meio da teoria do individualismo dos direitos humanos, um aspecto recente do pensamento ocidental que fulmina formas de experiência de vida que não podem ser articuladas em termos individualistas ${ }^{649}$, conforme tratamos no item 4.2.3 supra.

${ }^{647}$ SIEBER, Ulrich. "The forces behind the harmonization of criminal law"

${ }^{648}$ Por meio das diversas convenções e tratados de direitos humanos firmados, como a Declaração Universal de Direitos Humanos, Convenção Americana de Direitos Humanos, Convenção Europeia de Direitos Humanos, os Pactos das Nações Unidas de Direitos Civis e Políticos e de Direitos Sociais e Econômicos, as Convenções contra o Genocídio, contra a Tortura, as Convenções de Genebra. Também os esforços internacionais na área de combate ao terrorismo e organizações criminosas, no âmbito internacional, assim como a prevenção à corrupção.

${ }^{649}$ KOSKENNIEMI, Martii. "Hersch Lauterpacht and the Development of International Criminal Law", op. cit., p. 824. 
A realidade nos mostra que o contexto nacional das legislações prevalece no enfrentamento da criminalidade transnacional e que, por mais que existam esforços para a cooperação internacional, dificilmente a solução jurídica para o problema decorrerá da aplicação primária da legislação internacional. A cooperação é um passo para a harmonização, mas que ainda não se encontra em grau elevado de abstração (para produção genérica e abstrata de produção de efeitos para os indivíduos destinatários das normas) e de desenvolvimento (corpus juris abrangente) como uma instância supranacional de produção de regras e decisões para representação em direito penal. $O$ tratado de cooperação pressupõe a existência de certo grau de harmonia jurídica, inicial e que poderá se alastrar pelo aprofundamento dos laços que unem diferentes culturas ou matrizes jurídicas.

\subsubsection{Objetivos e Realizações: ativismo judicial}

Os tribunais internacionais, e também os de direitos humanos, concentram uma série de atribuições que poderiam representar a grande conquista na defesa dos direitos humanos da história - o que pode muito bem ser em termos simbólicos não é, em verdade, na realidade. $\mathrm{Na}$ chamada luta contra a impunidade dos crimes mais graves contra a humanidade, os tribunais representam a aplicação do direito internacional, do direito penal internacional, na retribuição do fato criminoso, na função de prevenção geral, reabilitação, e ainda contribuem para o próprio desenvolvimento do direito internacional, produzem um registro histórico dos crimes julgados e dos eventos que lhes são substrato, permitindo que sejam ouvidas as vítimas e testemunhas ao mesmo tempo que reafirmam os valores da justiça e do respeito aos direitos humanos. Também determina comportamentos para os Estados, como os deveres de indenização.

Com relação ao valor histórico, DAMASKAS ${ }^{650}$ questiona a afirmação de que o Tribunal de Nuremberg teria contribuído para escrever a história dos fatos que foram objeto de julgamento (embora a existência em si do tribunal seja indiscutivelmente histórica). Ela afirma que embora seja frequentemente citado o julgamento de Nuremberg como um exemplo do precioso material histórico produzido, muito da prova documental examinada

${ }^{650}$ DAMASKAS, Mirjan R. "What is the point of international criminal justice?", in Yale Law School, Faculty Scholarship Series, Paper 1573, 2008, p. 338. 
pelo tribunal poderia ter sido obtida pelo método histórico de qualquer forma, ressalvando que o material original histórico de fato produzido foram as provas testemunhais. Com relação ao julgamento pelo TPII, o tribunal afirmou que "esse Tribunal não é um árbitro final dos fatos históricos. Isso é para historiadores" ${ }^{651}$.

Pode haver a impressão de que a defesa dos elementos jurídicos, da dogmática penal, indique a defesa dos acusados pelos crimes, e que a gravidade das condutas justifique a superioridade dos interesses de punir. Ao contrário, a defesa dos elementos dogmáticos e dos princípios do direito penal é a defesa da qual qualquer cidadão pode lançar mão e está no centro da evolução do Estado de Direito. A manipulação casuística e seletiva indica o mau uso do direito que não se libertou dos fins e que descuida dos meios, que serve para uns mas não para outros, do direito que confunde a defesa dos princípios do direito penal com a defesa dos réus. Isso leva a uma distorção clara quando se analisa a jurisprudência dos tribunais de direitos humanos, especialmente do sistema interamericano.

A forma de compreender o sentido de uma convenção depende da forma como suas cortes a interpretam, algumas vezes pendendo para uma interpretação mais alargada, outra mais restritiva, a depender de uma série de variáveis, como a tradição jurídica dos membros do tribunal, a concepção sobre o direito aplicável, as fontes de direito aplicável, mas sobretudo um sentido de realização de justiça. Entendemos que diante do princípio da máxima efetividade dos direitos humanos, a vincular principalmente o Poder Executivo, esse princípio vincula o Judiciário de forma distinta, pois cabe ao Judiciário ponderar os diversos direitos fundamentais arguidos pelos dois lados do litígio, e nenhum tendo precedência sobre o outro pelo simples fato de poder ser considerado, formalmente, um direito humano ${ }^{652}$. Assim, apenas por estar inscrito num tratado de direitos humanos, não se pode de plano esperar que um tribunal considere que este seria um direito humano superior a outros que possam ser reconhecidos pela corte num julgamento.

Ainda que de difícil conceituação, a compreensão do que seja ativismo jurídico pode nos ajudar a visualizar no que se baseiam algumas das nossas críticas, até porque se

\footnotetext{
${ }^{651}$ Caso Nikolic, TPII (IT-94-2-S), julgamento de 18 de dezembro de 2003, § 122. No original, "this Tribunal is not a final arbitrer of historical facts. That is for historians".

${ }^{652}$ Certamente que pela análise dos elementos materiais poderá se chegar uma preponderância de um direito em relação ao outro. A teoria constitucional fornece elementos mais amplos para essa discussão.
} 
corre o risco de taxar de ativismo jurídico aquela decisão com a qual não concordamos. Mas em verdade, é mais concreto do que isso. "O ativismo judicial é um termo usado para descrever as ações de juízes que ultrapassam os seus deveres constitucionalmente estabelecidos de aplicar a lei aos fatos em casos individuais e 'legislam' do tribunal. Criam novos direitos constitucionais, emendam os existentes, ou criam e emendam legislações existentes para se encaixar em suas próprias noções de necessidades da sociedade"653.

Mas para não nos perdermos no debate a favor ou contra o ativismo judicial ${ }^{654}$, sobretudo sendo a tradição civilista muito mais resistente a esse ativismo (tendência aproxima-se mais da tradição do direito da common law), e diante de um relativo coerente material de judiciais dos tribunais internacionais, há que se pontuar algumas observações partindo do pressuposto de que a interpretação não poderá inovar criando novas regras e violando as garantias penais e processuais penais contra os próprios direitos humanos consagrados internacionalmente.

A obrigação de punir as violações à Convenção Americana dos Direitos Humanos não está prevista na própria convenção, mas decorrem da aplicação pretoriana, conforme evidenciou-se na primeira decisão da CorteIDH, fundada no art. $1^{\circ}$ da Convenção, cujo mandamento contem a obrigação geral de garantir e respeitar os direitos contidos na Convenção, interpretando de maneira ampla este dispositivo, entendido como uma obrigação do Estado de mobilizar todas as suas estruturas do poder público e garantir, no âmbito judicial, o exercício dos direitos humanos consagrados pela Convenção - dessa obrigação resulta o dever de prevenir, investigar e sancionar toda violação a direitos humanos ${ }^{655}$.

O fato de a CorteIDH ter competência para condenar os países por desrespeito às obrigações contidas no tratado original não imediatamente atribui à Corte o papel de

\footnotetext{
${ }^{653} \mathrm{Cf}$. HAUSKNECHT, Bruce, "judicial activism is the term used to describe the actions of judges who go beyond their constitutionally prescribed duties of applying law to the facts of individual cases, and 'legislate' from the bench. These judges create new constitutional rights, amend existing ones, or create or amend existing legislation to fit their own notions of societal needs. "Focus on the Family's Issue Analysis" The Law \& the Courts, $Q \& A$ - Judicial Activism, (disponível em: http://www.citizenlink.org/FOSI/Courts/A000001374.cfm. Acesso 03.01.2015). Em uma versão mais equilibrada, SHAPIRO, Martin. "Fathers and Sons: The Court, the Commentators, and the Search for Values", The Burger Court: the Counter-Revolution that wasn't, Vicent Blasi, 1983, pp 236-38.

${ }^{654}$ Para maiores reflexões sobre o debate, v. LIPKIN, Robert Justin. "We Are All Judicial Activists Now", University of Cincinnati Law Review, vol. 77, Widener University School of Law, 21 de fevereiro de 2009, Widener Law School Legal Studies Research Paper No. 09-23.

${ }^{655}$ CorteIDH, Velázquez Rodrigues v. Honduras, 29 de julho de 1988, Série C, no 4 (§§ 162 a 168).
} 
instância revisora das decisões judiciais de um país. Foi nesse sentido o estudo realizado por MALARINO a respeito do ativismo judicial praticado pela CorteIDH. Nos casos em que a Corte determina a abertura de processos judiciais com decisões já transitadas em julgado (decisão absolutória do poder judicial nacional), acaba exercendo um poder jurisdicional revisional, mas em condições ainda mais criticáveis: dentro de um regime probatório mais relaxado do que o exigido pelo regime processual penal dos países ${ }^{656}$. Isso porque, o que se julga, é a responsabilidade internacional do Estado, flexibilizando as exigências formais do processo penal diante da busca pela conferência da máxima efetividade aos direitos humanos. Por ser, portanto, mais simplificada a demonstração da responsabilidade do Estado diante de uma violação de direitos humanos, inclusive em razão da responsabilidade objetiva do Estado, ela não pode prevalecer para fundamentar a condenação penal e a aplicação de uma pena restritiva de liberdade, com critérios muito mais rígidos de apuração e atribuição de responsabilidade de cortes nacionais, sustentando a revisão de uma decisão absolutória transitada em julgado.

MALARINO, após rever as decisões da corte com especial enfoque nos últimos dez anos, confirma que a aplicação do direito da Convenção Americana se converteu em algo muito distinto daquele que foi aprovado pelos Estados em sua assinatura, na Conferência de San José. Essa nova Convenção possui termos alterados tanto em relação ao entendimento a respeito dos direitos protegidos e a forma como essa proteção se efetiva pela atuação dos Estados, quanto pelo entendimento da própria competência e função do tribunal. Consagra-se, para o autor, a atuação do tribunal dentro de três perspectivas: ativismo judicial, punitivismo e nacionalização. $\mathrm{O}$ autor justifica falar em ativismo em relação à atuação da CorteIDH quando cria normas novas ou suprime as originalmente pactuas, procurando por meio da decisão judicial modificar o direito com o fim de atualizá-lo às necessidades atuais do momento de sua aplicação. A crítica à inovação ocorrida no âmbito interamericano ocorre porque o sistema não está aberto às fontes de todo o direito internacional, daí se ponderar com o maior cuidado a integração de fontes, como a norma costumeira, os princípios gerais de direito, entre outras.

\footnotetext{
${ }^{656}$ MALARINO, Ezequiel. “Activismo judicial, punitivización y nacionalización: tendências antidemocráticas y antiliberales de la CIDH". In: Derechos humanos y derecho penal. Bogotá: Pontificia Universidad Javeriana/ Grupo Editorial Ibáñez, 2012, p. 69.
} 
Para além de se verificar se o entendimento da CorteIDH é ou não baseado na Convenção, MALARINO propõe a reflexão sobre uma base anterior: a de se saber se a CorteIDH pode normativamente decidir com base nas regras que não derivam da Convenção Americana de Direitos Humanos. Além disso, como a maior responsabilidade da CorteIDH é poder reprimir a ação dos Estados, ela somente poderá condenar violações indicando o desrespeito à Convenção, com base no art. 63. Portanto, todas as violações aos direitos humanos que ela encontrar, ela procurará ligar a um dispositivo da Convenção para poder atingir seu objetivo de condenar um país e procurar melhorar o padrão de respeito aos direitos humanos no continente.

Para atingir seus objetivos, algumas práticas da CorteIDH são recorrentes: indicar que a proibição às anistias se dão com base nos arts. 1.1, 2, 8 e 25 da Convenção, embora não esteja clara essa conclusão ${ }^{657}$; que a garantia do ne bis in idem pode ser flexibilizada $^{658}$, o uso dos superlativos para justificar uma razão maior de decidir e criar as regras jurídicas (crimes atrozes, da máxima gravidade, que agridem a razão humana); exclusão do princípio da irretroatividade da lei penal para casos de crimes contra a humanidade; proibição da prescrição para graves violações. Para chegar a estas regras, a CorteIDH se vale de fontes não previstas na Convenção Americana, quando a Convenção prevê em seus artigos 33 e 62.3 a competência para conhecer casos relativos à aplicação e interpretação da mesma Convenção e em relação aos compromissos adotados pelos Estadosparte da Convenção. Por certo, não se refere aos demais compromissos porventura firmados pelos Estados, porque estes não podem ser da atribuição temática da CorteIDH ${ }^{659}$.

O direito penal internacional passou por um processo de afastamento das garantias democráticas de direito diante de uma situação excepcional e deverá retomar seu curso para respaldar-se fora da "emergência perene" dentro dos preceitos do Estado de Direito, que deverão ser perseguidos não somente dentro dos Estados, mas também no âmbito do direito internacional. Assim é que chegamos na

\footnotetext{
${ }^{657}$ Caso Barrios Alto v. Peru.

${ }^{658}$ Caso Almonacid Aurellano v. Chile.

${ }^{659}$ Ademais, as regras para ampliação da competência da CorteIDH, arts. 76 e 77, estabelecem a competência para emendar a Convenção.

${ }^{660}$ MOCCIA, Sergio. La perenne emergenza: tendenze autoritarie nel sistema penale. Nápoles: Edizioni Scientifiche Italiane, 1995.
} 
proposição de defender um direito da conformação de preceitos abstratos, invocando a lógica abstrata e razão justa que negue o casuísmo. E procurarmos questionar quando defendemos as formas de interpretação evolutiva quando ela esteja de acordo com o fim buscado, em atenção à provocação que Bobbio faz, de que nunca nos alegramos quando a interpretação evolutiva ou criadora era invocada pelos juristas nazistas ${ }^{661}$. MALARINO ${ }^{662}$ nos adverte de que sabemos que a submissão do juiz à lei, como querido pelos pensadores iluministas, não é possível, por limitações do legislador e da linguagem normativa, mas que "esta sujeição deve permanecer como uma aspiração ou meta a ser cumprida no grau mais alto possível, pois disso depende a legitimação da atividade judicial”. Relembra a JUVENAL (Satirae, VI), que perguntava Quis cuostodiet ipsos custodes?, retomando os questionamentos metalinguísticos típicos da ciência jurídica quando se trata da atribuição de poder.

Em todo caso, quando a lei é clara, ela é um limite franco à atividade judicial, cuja transposição deverá requerer a máxima invocação lógica e jurídica, mas quando se justifica pela necessidade dos fatos, ela se converte num instrumento de realização dos fins. $\mathrm{O}$ argumento ideológico é forte entre aqueles que compartilham a mesma ideologia ${ }^{663}$. MALARINO apresenta três casos em relação aos direitos que têm sido colocados de lado pela CorteIDH para representar o ativismo judicial e o julgamento contra a convenção e a favor da punição pela violação aos direitos humanos.

O primeiro exemplo é do art. 8.4 da Convenção ${ }^{664}$ que prevê que "o acusado absolvido por sentença transitada em julgado não poderá ser submetido a novo processo pelos mesmos fatos". Apesar dessa norma, a CorteIDH tem o entendimento de que se apareceram novos fatos ou provas que possam permitir a determinação de responsabilidade pelos crimes contra a humanidade, podem ser abertas as investigações, ainda que haja sentença absolutória transitada em julgado, "visto que as exigências da justiça, dos direitos das vítimas e a letra e espírito da Convenção Americana desloca a proteção do ne bis in

${ }^{661}$ BOBBIO, Norberto. El problema del positivismo jurídico, México: Fontamara, 1991, p. 35 (trad. Ernersto Garzón Valdés).

${ }^{662}$ MALARINO, Ezequiel. “Activismo judicial, punitivización y nacionalización: tendencias antidemocráticas y antiliberales de la CorteIDH”. In: PASTOR, Daniel R. (dir.). El sistema penal en las sentencias recientes de los órganos interamericanos de protección de los derechos humanos. Buenos Aires: Ad-Hoc, 2013, p. 40.

${ }^{663}$ Idem, p. 40.

${ }^{664}$ Pacto de São José da Costa Rica, de 22 de novembro de 1969, promulgado pelo Decreto No 678, de 6 de novembro de 1992. 
idem". Esse entendimento foi explicitado no julgamento dos casos Almonacid Arellano contra Chile e no caso La Cantuta contra Peru.

O segundo diz respeito ao art. $9^{\circ}$, primeira parte, que prevê que "ninguém poderá ser condenado por atos ou omissões que, no momento em que foram cometidos, não constituam delito, de acordo com o direito aplicável." Contrariamente a este dispositivo, a CorteIDH entende que o Estado não poderá pretender a aplicação da teoria da irretroatividade da lei penal para escusar-se de seu dever de investigar e sancionar os responsáveis em relação a fatos que segundo o direito internacional seriam qualificados como crimes contra a humanidade, conforme decisão nos mesmos casos citados acima.

O terceiro caso citado por MALARINO diz respeito ao art. 8.1 da Convenção que prevê que "toda pessoa terá o direito de ser ouvida, com as devidas garantias e dentro de um prazo razoável, por um juiz ou Tribunal competente (...)”. Não obstante, a CorteIDH decidiu que o dever de o Estado satisfazer plenamente os requerimentos da justiça prevalece sobre a garantia ao prazo razoável. A razoabilidade da duração do processo, como um critério a ser construído, requer que ela seja definida com base num critério temporal, afinal é esse o elemento jurídico vertido, e não com base na gravidade do crime. A CorteIDH usou o critério da gravidade para afastar o princípio do tempo razoável, misturando as racionalidades por trás dos direitos no caso La Cantuta contra Peru e mais uma privilegiou a aplicação da norma que determina a punição diante da regra de garantia processual.

\subsubsection{O braço penal dos direitos humanos}

Pelo presente estudo, confirma-se o recurso ao direito penal no processo de afirmação dos direitos humanos. Uma confirmação não sem reservas, consoante procuramos demonstrar ao longo dos últimos capítulos e, justamente por isso, num processo a ser devidamente curado. Os direitos humanos, como o direito internacional humanitário, aplicam-se a entidades coletivas, os Estados ou partes em conflito, objetivando ordenar um contexto e melhorar práticas que respeitem os direitos dos sujeitos envolvidos. As aspirações se operam no plano público, de políticas públicas, ou nos remédios civis, como dever de abstenção, direito de manifestação, direito a indenização e esforços para restauração da 
situação anterior. O foco principal do direito penal internacional, por outro lado, é o da atribuição de culpa a indivíduos, por meio do direito penal e de todo seu arsenal simbólico: interrogatórios, formalidade judicial, punições, prisões, apaziguamento de emoções, o que o faz inclusive uma das áreas do direito mais aptas ao sensacionalismo, um teatro do drama humano, a sala de julgamentos dos tribunais nacionais ou internacionais chama a atenção da opinião pública tanto quando os indivíduos que lá sentam para serem julgados.

Mas há o entendimento que procura unir as duas áreas jurídicas, de que as violações aos direitos humanos e ao direito humanitário deve gerar uma criminalização em direito internacional penal, automaticamente, afastando-se os critérios de culpabilidade e de se o direito penal é a ferramenta apropriada para lidar com o problema ${ }^{665}$. Confluindo o direito humanitário e os direitos humanos em direção às normas penais, tal como temos visto, além de não se legislar com as mesmas lentes, com os mesmos critérios e rigor, a atividade do judiciário tende a expandir os elementos da proibição criminal, tendo em vista o objetivo de assegurar a proteção dos direitos humanos, criando mais uma vez uma dicotomia indesejável de que o direito penal é contrário aos direitos humanos. Recepcionando normas de direito humanitário, como os artigos 86.2 e 87.3 do Protocolo Adicional I à Convenção de Genebra, a jurisprudência criminaliza o âmbito integral do que fazia parte do direito humanitário, mas também declara o comandante responsável pelos crimes de seus subordinados, ainda que não praticados por ele, mas cuja responsabilidade lhe foi atribuída por uma norma.

De forma semelhante, KOSKENNIEMI ${ }^{666}$ também coloca em perspectiva a obrigação moral de exercer um direito superior, evitar maiores catástrofes humanitárias, às custas de um injusto menor, numa negociação entre morais disponíveis, entre algo

\footnotetext{
${ }^{665}$ ROBINSON menciona os casos em que se confunde as obrigações de um comandante durante um conflito, do direito humanitário, com outra completamente distinta e mais complexa, da responsabilidade criminal pelos atos de outro: a obrigação de punir violências passadas, que é bastante distinta da culpa do comandante pelos crimes ocorridos. Cita-se, para esse efeito, a decisão do caso Krnojelac, no qual o comandante, acusado de crimes contra a humanidade (tortura, assassinato, perseguição) pela responsabilidade pelo comando, e condenado por estes crimes, a Câmara de Apelação afirmou que "it cannot be overemphasized that, where superior responsibility is concerned, na accused is not charged with the crimes of his subordinates but with his failure to carry out his duty as a superior to exercise control", Caso Krnojelac, julgamento, Câmara de Apelação, TPII (IT-97-25-A), 17 de setembro de 2003, § 171 e ROBINSON, D. "The identity crisis (...)”, op. cit., p. 951.

${ }^{666} \mathrm{O}$ autor questiona a prática que autoriza a contenção da violência pelo uso da violência, buscando qual a racionalidade por trás de um ataque que vitimou cerca de 500 civis, após o bombardeio liderado pela OTAN na Iugoslávia, em 1999. KOSKKENIEMI, Martii. "The Lady Doth Protest too much Kosovo and the turn to Ethics in International Law". The Modern Law Review, vol. 65, n 2, março 2002, pp. 159-175.
} 
formalmente ilegal, mas moralmente necessária. Talvez porque, como afirma o autor, os internacionalistas transformaram-se em moralistas pela lógica do argumento da intervenção humanitária, às vezes colocando um modelo de direito perfeito diante do criminoso de guerra, do belo diante da fera ${ }^{667}$. E a moral não é a de não punir, mas também de punir mal, por meio de manobras que somente são aceitas no direito internacional porque diante de gravíssimos crimes, sendo lúcidas as palavras de FARIA COSTA:

\begin{abstract}
"Se se aceitasse, sem angústias ou perversões de discurso, que a nobreza do direito penal está, não só em punir os culpados, mas também em absolver os inocentes e que o mundo não perece nem acaba quando um culpado não é punido porque se aplicaram princípios, tais com o in dubio pro reo, que constituem um patrimônio da humanidade e não já só valores de tonalidade civilizacional.
\end{abstract}

Se se aceitasse que o direito penal - enquanto ordem de liberdade, de pacificação mas também de repressão e de constrição de direitos fundamentais e, por isso, ordem de aparente dissonância mas que, em definitivo, é e deverá ser sempre uma ordem de consonâncias normativas - é um irrecusável, um essencial contributo para a contínua e sempre incompleta caminhada da Humanidade, seja levada a cabo pelos córregos escarpados do local ou pelas largas avenidas e circulares do global" 668 .

Quando ARENDT afirmou que o enforcamento de Göring era necessário, mas totalmente inadequado ${ }^{669}$, visto que sua culpabilidade transcendia e destruía qualquer ordem legal, percebemos que algo estava errado com uma punição simbólica, visto que o diante de uma tragédia tão grande, os eventos subsequentes têm uma significância metafísica e que a punição individual não é compatível com a ideia de justiça e de equilíbrio dos fatos e da pena. Da mesma forma, KOSKENNIEMI se refere à prisão de Milosevic, e cujo cumprimento individual de uma pena não representa uma resposta adequada à morte de 200 mil pessoas. Afirma o autor que "se o julgamento tem significado, então o significado está em outra parte para além da punição dada a ele". Mais uma vez se ressaltam os aspectos didáticos, históricos e éticos. Mesmo diante de uma norma injusta, que deixa impune graves

${ }^{667} \mathrm{Na}$ expressão de NOUWEN, Sarah. "Justifying justice". In: CRAWFORD, James; KOSKENNIEMI, Martii. The Cambridge Companion to International Law, Cambridge: Cambridge Univ. Press, 2012, p. 329. 668 FARIA COSTA, José. Op. cit., p.190.

669 Citado por FREI, N. "Le retour du droit em Allemagne. La justice et 1'histoire contemporaine après 1'Holocauste - un bilan provisoire". In: BRAYARD, F. (ed.). Le génocie des Juifs entre procès et histoire 1943-2000, 2000, p. 57, citado por KOSKENNIEMI, Martii. "Between Impunity and Show Trials". Max Planck Yearbook of United Nations Law, vol. 6, 2002, p. 2. 
crimes, diante de uma norma socialmente eficaz mas axiologicamente ilegítima ou injusta ${ }^{670}$, permanecem os fundamentos para o exercício do direito de punir?

Ainda assim, busca-se a construção do "direito justo", pela fórmula de Radbruch, no qual os fundamentos do direito penal são uma pedra no sapato da realização desta justiça. Mas não é pelo direito que se protegem as sociedades dos crimes massivos, nem por ele que a sociedade ficará curada, porque estes ocorrem para além da lógica racional do direito, quiçá numa reflexão extrema da advertência trazida por TEUBNER, de que a jurisdicialização não resolve os conflitos, mas os aliena, mutilando os conflitos sociais, reduzindo-os a um mero caso judicial e, desse modo, exclui qualquer possibilidade de uma resolução socialmente adequada e prospectivamente orientada ${ }^{671}$. Fundamentalmente, a racionalidade penal funciona de forma binária, culpado ou inocente, sem matizar complexidades políticas e sociais que estão na base de qualquer crime e especialmente os ocorridos de forma massiva e sistemática. E vemos a construção de um direito dentro dos princípios do Estado de Direito e que respeita as garantias processuais a todos os indivíduos, e um direito aplicável para as máximas violações aos direitos humanos, um direito apartado das regras estáveis, orientado para a condenação e para a estruturação de mecanismos jurídicos originais.

$\mathrm{O}$ uso do direito penal como instrumento de vingança, direcionado a julgar (condenar) determinadas pessoas ao invés dos fatos abstratamente considerados, representa uma perversão do uso dos instrumentos do direito penal, a chamada seletividade penal, apontada por SAAD-DINIZ. O autor empreende uma busca pela racionalidade penal, em relação aos questionamentos da fraqueza da função preventiva ao tentar resolver os problemas sociais ao mesmo tempo que integrar as sociedades sob o mesmo panorama jurídico. Porque ao final teremos que julgar os perpetradores das máximas violações de direitos humanos com os mesmos instrumentos que irão se perenizar na sociedade, numa ordem que se quer justa, coerente e solidaria ${ }^{672}$.

\footnotetext{
${ }^{670}$ SWENSSON JUNIOR, Lauro Joppert. Anistia penal. Problemas de validade da Lei de Anistia Brasileira (Lei 6.683/79). Curitiba: Juruá, 2011, pp.177 ss.

${ }^{671}$ TEUBNER, Günther. "Legal Irritants: Good Faith in British Law or How Unifying Law Ends Up in New Differences". Modern Law Review, vol. 61, pp. 11-32, 1998.

${ }^{672}$ SAAD-DINIZ, Eduardo. "El enclave de los juicios de transición: observación del caso brasileño". Revista de derecho penal y procesal penal, 12, 2011, p. 2086. Conforme discorre o autor: "Pero cómo hacer que ese sentimiento de objeción al autoritarismo - y de sufrimiento humano - una construcción jurídica racional para orientar la operatividad de la 'Justicia de Transición'; precisamente allí está el lamento de la racionalidad jurídica (...). Hasta este punto me parece que la investigación de las posibilidades de un juicio de validez universal sobre la superación histórica del pasado mediante el derecho se confronta con sus límites. Para
} 
A atribuição de uma função pacificadora ao direito penal contradiz com uma tendência seletiva do direito, ainda mais do direito penal, conforme descreveu TEUBNER a respeito das tendências do direito moderno: o direito tende a ser cada vez mais seletivo, sua conexão ocorre de maneira fragmentária em oposição a uma organização total e integral, as relações tendem a ser estabelecidas por meio das diferenças e o desenvolvimento não ocorre de maneira conjunta, mas por trajetórias independentes e por meio do conflito estabelecido entre elas ${ }^{673}$. Em última instância, o que estamos assistindo até o final em que essa nossa discussão nos remete é precisamente um retrato do adiantado por TEUBNER em 1998.

Os diferentes sistemas (direito civil x common law; direito penal $\mathrm{x}$ direitos humanos; cortes internacionais $\mathrm{x}$ tribunais nacionais; direito $\mathrm{x}$ política $\mathrm{x}$ sociedade $\mathrm{x}$ cultura) se definem por suas oposições e deixam de refletir e de se reportar a totalidade de um sistema, do qual são parte (visão fragmentária), mas também fazem parte (visão integral). Assim como a distintas formas de cumprimento das decisões das cortes de direitos humanos e da eficácia própria do funcionamento dos tribunais ad hoc e da seletividade dos julgados em direito penal internacional, das diferenças entre os julgamentos das cortes nacionais, internacionais e entre as cortes internacionais entre si, nos indicam um difícil contexto operativo, na imagem do labirinto de MANES, no qual se encontra o direito e seus cidadãos. Por que esperar que as cortes de direito reconheçam os direitos humanos violados nacionalmente, se o próprio direito estatal já está conformado para o respeito aos direitos humanos? Não há razão epistemológica para se esperar que o respeito aos direitos humanos será melhor vertido por uma decisão internacional do que por um tribunal interno. E em relação ao direito penal, diante da complexidade da sua relação com o sistema de direitos humanos, afirmando e negando direitos, veiculado em decisões contrapostas, mas manipulando a força autoritária do Estado, não é de se negar que ele atue por preferências subjetivas $^{674}$, servindo ao despropósito da objetividade e clareza que se espera dele. E a mera possibilidade de se submeter a um decisionismo vergado de subjetividade, em que pode ou não haver o cumprimento de uma decisão judicial, corresponda ao que TEUBNER se refere ao tratar das irritações legais, ao se tentar importar instituições que ainda genuinamente não

atravesar estos límites sería recomendable elevar el plan de la consciencia (...) y desarrollar la viabilización de una determinación práctica de esa consciencia, o sea, en nuestras vidas concretas, independientemente de una mediación simbólica de los mecanismos jurídicos (...)".

673 TEUBNER, op. cit., p.14.

674 REALE JÚNIOR, Miguel. “Razão e subjetividade”. Ciências Penais, vol. 00, 2004, p. 226. 
interagem com as locais, promovidas pelas teorias de "convergência", em relação aos movimentos de internacionalização, e de "equivalência funcional”, na solução dos mesmos problemas que as perspectivas de integração já operando no plano econômico e social nos remetem. Essa constante leva a uma dupla-fragmentação, ao mesmo tempo que leis mais uniformes, leis mais fragmentadas refletindo a multiplicidade de formas de sociedades jurídicas.

A ideia de fragmentação considera mais as rupturas do que as convergências, mais as descontinuidades do que as continuidades, porque não se exportam institutos e instituições relevantes para todo o sistema de justiça criminal. As instituições relacionadas ao controle social não se baseiam somente em sua interface judicial, mas também em sistemas de direito administrativo sancionador ou sistemas sancionadores compostos de atores privados ${ }^{675}$.

A defesa dos direitos humanos não deveria preterir o caráter fragmentário e de ultima ratio do direito penal, diante de sua aspiração naturalmente à expansividade, cedendo passo quando se pretenda reduzir ou limitar a atuação das garantias penais e processuais penais. Porque os direitos humanos se realizam de diversas formas, como reconhecido por AMARTYA SEN ${ }^{676}$, extravasando a esfera legal e, mais especialmente, a do direito penal. Mais especialmente, que o local dos direitos humanos não está em sua superioridade e referência para se tornarem exigíveis por meio dos diplomas legais que o reconheçam, mas por sua capacidade de se realizarem inclusive a despeito deles, no que é reconhecido por ter se tornado uma lingua franca ética ${ }^{677}$.

Os princípios e garantias que orientam o objetivo do direito penal, de contenção do poder arbitrário, são traduções bem acabadas dos direitos humanos de primeira geração e novas condições institucionais e políticas que permitam que esses direitos humanos também possam ser reivindicados em aparatos e segundo conceitos jurídicos modernos não

${ }^{675}$ SIEBER, Ulrich. "The forces behind the harmonization (...)", op. cit., p. 416.

${ }^{676}$ SEN, Amartya. "Human rights and the limits of law", Cardozo Law Review, 2005-2006, 27.

677 TASIOULAS, John. "Towards a philosophy of human rights" (disponível on-line, https://www.academia.edu/1839196/Towards_a_Philosophy_of_Human_Rights, Acesso 15.12. 2014). TASIOULA, John. "On the Nature of Human Rights". In: ERNST, G.; HEILINGER, J-C (eds). The Philosophy of Human Rights: Contemporary Controversies, Berlim/Boston: Walter de Gruyter, 2012, pp.4043; HABERMAS, J. 'The Concept of Human Dignity and the Realistic Utopia of Human Rights', no seu The Crisis of the European Union: A Response, Cambridge, UK: Polity Press, 2012, pp. 81-87. 
podem fundamentar uma revogação parcial destes princípios e garantias. Quando o direito de uns é diferente do direito dos outros, deslegitimamos a resposta jurídica e perdemos a chance de criar um "sentido cívico comum, fundado precisamente na assimetria entre a violação do direito e o próprio direito" 678 .

${ }^{678}$ FERRAJOLI, Luigi. "Entrevista a Luigi Ferrajoli”, por Eduardo Maia Costa/José Mouraz Lopes. Julgar. Coimbra: Wolters Kluwer, set-dez, 2008. 


\section{CONCLUSÃO}

A ampliação do direito penal pelos direitos humanos orientada por uma tendência expansionista movimenta-se segundo a) três momentos (a.1. compreensão e reforço mútuo, a.2. desconfianças e; a.3. divergências), b) três tendências (b.1. aproximação dos esforços normativos, b.2. sistemas auto-confirmantes e retro-confirmantes, b.3 rarefação do poder de contenção do direito penal) e c) três consequências (c.1. campos normativos expansivos, c.2. inconsistência do sistema penal internacional e; c.3 dispersão e fragmentação).

\section{a) Os três momentos}

a.1) Compreensão e reforço mútuos. Essa fase é caracterizada pela identificação de que os valores inscritos como cláusulas máximas em direitos humanos precisam estar garantidos por esforços no campo penal. A aplicação da sanção criminal pelas violações mais graves aos direitos humanos, reconhecida e aceita como norma formal ou costumeira, é fortalecida pela criação dos tribunais nacionais, desde o Tribunal de Nuremberg até o atual TPI, pelos conceitos de jurisdição universal, propulsionados pelo direito internacional humanitário e pelos tratados e convenções de direitos humanos. Esse momento é caracterizado pela preparação de ideia de que se está pavimentando o caminho para a construção de um futuro orientado pelos valores de uma sociedade solidária e reunida em torno da busca da paz e respeito aos direitos humanos fundamentais.

Essa perspectiva pode ser vista como um sistema ou como atributo da própria norma, como nos ensina SAAD-DINIZ, ao afirmar que a norma exerce a função de criar uma expectativa estável e contra-fática do comportamento, pressupõe a tomada de decisão em agir conforme ou contra ela, e preenche adequadamente sua função regulatória. Daí, “depreendem-se duas grandes características: as expectativas de sanção e todas suas consequências no plano real e simbólico, seja para a estabilização do incerto, seja para dimensionar o futuro" ${ }^{679}$, especialmente adequado para o ambiente instável internacional e

${ }^{679}$ SAAD-DINIZ, Eduardo. Inimigo e pessoa no direito penal. São Paulo: LiberArs, 2012, p. 54. 
pelo caráter civilizatório de suas normas. As normas de direito penal internacional buscam estabilizar o incerto, ainda que não criem um padrão normativo rígido e estável, e dimensionam suas intenções para o futuro, diante do pouco que se conseguirá modificar em termos comportamentais e judiciais no curto prazo.

a.2) Desconfianças. Quando a resposta penal não parece dar conta das fraturas sociais, quando o conflito jurisdicizado reduz as perspectivas de compreensão social de estabilidade social, tem-se a impressão de que a distância em que se encontram os mecanismos de justiça internacional separam-na da realidade concreta e da necessidade de se dar uma resposta adequada no contexto local. Perspectivas modernas de se enfrentar o problema concreto passam a ser consideradas como mais adequadas do que a jurisdicionalização do conflito.

Agregam-se às desconfianças a perspectiva de uma expansão penal desorientada dos princípios que orientam a intervenção penal, mas sob a força propulsora da globalização, fazem erodir marcos fundamentais do direito penal, contentores do poder arbitrário. Ainda que elaboradas em relação às questões econômicas, a expansão penal é identificada pelas seguintes características: a) perspectiva prática de atuação por medidas de cunho preventivas; b) colocação em perigo dos interesses jurídicos relacionados à eficiência alocativa dos lucros; c) compensação da reduzida certeza da aplicação das consequências jurídico-penais pela maior gravidade das penas previstas (com reforço simbólico desta aplicação $)^{680}$. O direito penal internacional procura compensar sua fragilidade jurídica diante da realidade dos graves fatos por meio de leis duras e pelo reduzido campo de defesa dos acusados $^{681}$, produzindo um direito punitivo que se aparta do direito penal nacional.

A falta de complexidade do referencial teórico que programa essa expansão do alcance da norma penal e o direciona para punições alargadas, apoiada numa retórica pragmática, "condena as normas penais a níveis intoleráveis de indeterminação e falta de identificação precisa do que seja a interpretação político-criminalmente orientada" ${ }^{682}$. Essa

${ }^{680}$ SILVA-SÁNCHEZ, Jesús-María. A expansão do direito penal (...), op. cit., p. 98.

${ }^{681}$ ROBINSON, Darryl. "The identity crisis of international criminal law", Leiden Journal of International Law, 21, 2008, p. 944.

${ }^{682}$ Tomo emprestada a afirmação feita por SAAD-DINIZ, relativa à expansão da norma penal em relação ao controle de contingencias econômicas porque o raciocínio encaixa perfeitamente ao modelo por nós defendido. SAAD-DINIZ, Eduardo. "Fronteras del normativismo: a exemplo de las funciones de la información en los 
situação promove a conversão de problemas reais em soluções artificiais, numa ausência de solução sistêmica consistente e que conduza a uma política criminal justa e adequada aos casos concretos, colaborando com a construção de um contexto jurídico de instabilidade normativa. Assim, como criticado por DREIER, o comportamento decisório apenas acumularia soluções justas que, não obstante, seriam apenas parciais em relação ao sistema. Desta forma, o paradoxo encarnado pela criminalização das violações de direitos humanos na forma empreendida pelo direito penal internacional representa a solução justa que é adequada somente a uma parcela do sistema, ou seja, uma solução justa que não é necessariamente adequada para a realização do direito.

a.3) Divergências. A análise da atuação das cortes penais internacionais e de direitos humanos, de modo genérico, indica uma ponderação ampliativa das punições por violações dos direitos humanos, com inovações relevantes à hora de justificar o afastamento da incidência da garantia ou do direito do acusado. Ajustes importantes à teoria do direito internacional são feitos: a norma costumeira como fonte de direito internacional para criar obrigações aos Estados passa a criar obrigações também aos indivíduos; direitos e garantias penais e processuais penais são reinterpretadas e aplicadas contrariamente à sua regra original (irretroatividade da lei penal mais grave e imprescritibilidade retroativa, jurisdição e juiz natural, legalidade e norma costumeira).

Agregam-se a esse momento, iniciativas de lutas contra a impunidade de graves crimes e as críticas de que, encarnando os "show-trials", fortaleçam a dimensão expansiva da afirmação dos direitos humanos, apoiados na justiça substancial para sub-rogar as garantais de que os próprios direitos humanos são tributários. O direito penal internacional cada vez mais se afasta dos pressupostos do direito penal, numa artificial divergência entre direitos e garantias penais e a proteção dos direitos humanos.

\section{b) As três tendências}

b.1) Aproximação dos esforços normativos. Identificada a aproximação dos valores da humanidade, integrada pela lógica que impulsiona a globalização, a comunidade

programas de criminal compliance". Rev. Faculdade de Direito da Univ. de São Paulo. v. 108, jan/dez, 2013, p. 418 . 
internacional se organiza em torno da proteção dos direitos humanos e da efetivação das punições por suas violações. A produção de um consenso em torno da luta contra a impunidade e a produção legislativa internacional na conformação de um corpus juris abrangente contém uma potente força declaratória.

A produção expansiva nem sempre é seguida das ponderações que a aproximação do direito penal e do direito internacional requer: uma ação internacional concertada que, para o exercício do poder punitivo, requer as ferramentas dogmáticas da ciência penal. Considerando a segurança que a norma jurídica deve prover ao sistema, o direito penal internacional, em processo de formação, está se estruturando para aproximarse dos padrões de garantia e certeza da norma e a aplicação do direito.

b.2) Sistemas auto-afirmantes, retro-confirmantes A lógica preponderante é a da afirmação simultânea do projeto de proteção internacional dos direitos humanos e à medida que essa afirmação se fortalece, ela valida e confirma as afirmações anteriores. Nesse percurso, a comunidade internacional à frente do processo de normativização da punição, procura fortalecer a segurança da norma incriminadora, mesmo sem reconhecer que quando não havia essa segurança jurídica, algum acusado poderia ter sido absolvido. Apesar de somente o Estatuto do TPI ter previsto em escala mundial, como norma vinculante, a imprescritibilidade dos crimes contra a humanidade, esse reconhecimento posterior não impediu as outras cortes reconhecerem essa imprescritibilidade nos seus julgados.

A produção da condenação internacional redunda em termos criminológicos de pouca efetividade: os resultados associados à prevenção a largo prazo somente podem ser esperados diante de políticas extrapenais racionais que identifiquem fatores individuais e sociais que promovam a criminalidade. Um direito penal internacional carece de todas as ferramentas que legitimam o poder penal num território: a base social, cultural de uma sociedade, a política que se respalda nos valores penais e processuais penais locais, um sistema de justiça que atue numa trama complexa de prevenção, processamento, execução penal, e uma base legal paralela que sustenta o sistema jurídico penal, especialmente a base constitucional. 
O recurso à perspectiva preventiva dos julgamentos e das normas de direito penal internacional no diálogo produzido entre as cortes penais internacionais representa uma exaltação da sociedade punitiva, devendo a defesa dos direitos humanos reafirmar o compromisso integral com a promoção de uma sociedade harmonizada em torno da paz e do respeito ao legado jurídico do Estado de Direito. O direito fora do Estado de Direito corre grande risco.

b.3) Rarefação do poder de contenção do direito penal. $O$ direito penal internacional representa mais um campo privilegiado de expansão do direito penal, apesar de sua impotência em prevenir crimes, solucionar conflitos e punir os culpados pela máximas violações de direitos humanos. Com uma atuação simbólica e seletiva, afasta-se de sua pauta subsidiária, marcada pelo princípio da intervenção mínima e que vela pelos diversos direitos e garantias.

Os direitos humanos e o direito internacional vivem uma fase de encantamento com o direito penal, ou melhor, com sua perspectiva punitivista, e que não ajuda à perspectiva de contenção do poder repressivo do Estado-Nação e da comunidade internacional. Essa fase não se sustentará quando ficar claro que a função preventiva da norma de DPI é limitada, assim como a elaboração do bem jurídico em torno da proteção dos interesses da humanidade, da comunidade internacional e das gerações futuras. As críticas ao ativismo judicial e ao julgamento baseado na justiça substancial e divorciado do respeito às garantias que consolidam um dos momentos e instrumentos mais relevantes na proteção dos direitos humanos.

Torna-se claro e urgente a distinção entre as pretensas e reais funções do direito penal, sendo certo que no ambiente internacional as contradições do uso do instrumento punitivo amplificam-se diante do: consenso em torno da obrigação de punir; do coro em torno da justiça substancial, confirmado pelos tribunais internacionais, do sentimento de um novo patamar jurídico para proteger a humanidade dos crimes mais graves por intermédio do direito internacional. Não se resolvem, por meio do direito penal (nacional e internacional), as desigualdades sociais e nem o que fator desencadeante da criminalidade, ao mesmo tempo que a expansão acrítica e que relativiza as garantias do direito penal retira 
sua característica mais admirável, sua condição de ser uma expressão do processo civilizatório da humanidade ${ }^{683}$.

\section{c) As três consequências}

c.1) Campo normativo expansivo. O campo normativo decorre da previsão das regras, da aplicação das regras pela jurisprudência, mas especialmente da produção do direito concreto. A interpretação jurisprudencial tem interpretado os tratados de direito penal internacional, sob o argumento de conferir a máxima proteção aos direitos humanos violados, violando a máxima proteção aos direitos humanos dos ofensores, para além do que os tratados dispunham quando de sua ratificação. Essa interpretação extensiva, autorizada como regra de interpretação, é aceita uma vez que se trata de punir agressores indesejados pela comunidade internacional.

A informalidade da conformação do direito penal internacional, das teorias que apoiam a flexibilidade dos princípios da legalidade com base na previsibilidade de que o agente tinha conhecimento de que seu ato era ilícito, mas especialmente da maior simplicidade com que ocorre um julgamento de uma corte internacional em relação ao julgamento da corte nacional, não se pode dizer que o direito produzido por uma é qualitativamente mais avançado, em termos de análise, fundamentação e proteção dos direitos das partes, do que o da outra. A situação em que decisões internacionais mandam instaurar inquéritos, processar e punir indivíduos em casos já arquivados, deve ser cuidadosamente analisada para que não se instaure uma instância revisora ad hoc das decisões judiciais nacionais. O mecanismo de atuação das cortes de direitos humanos deve se dirigir ao Estado e servir como mensagem de adequação de suas práticas aos padrões de respeito aos direitos humanos.

Colocamo-nos diante do paradoxo: um direito penal que, ao mesmo tempo, protege e ameaça os direitos humanos, permitindo, concomitantemente, uma redução e um

${ }^{683}$ D’AVILA, Fabio Roberto. "Liberdade e segurança em direito penal. O problema da expansão da intervenção penal”. Revista de Estudos Criminais, São Paulo, no 41, abr.-jun./2011, p. 96. 
alargamento do direito penal ${ }^{684}$ e nesse cabo de guerra o poder expansivo dos direitos humanos tem ganho espaço e projeção, à custa do poder de contenção do direito penal.

A jurisprudência internacional de proteção aos direitos humanos tem se notabilizado pela inversão do princípio da subsidiariedade do direito penal, este "direito odioso", "instrumento brutal", que somente deve ser utilizado como derradeira opção, tornase meio prioritário de ação. ${ }^{685}$

c.2) Inconsistência do sistema penal internacional A humanidade se encontra mais conectada do que nunca, considerando as diversas oportunidades de interconexão, físicas e imateriais, e a cultura dos direitos humanos é o fio condutor de união dos povos sob o mesmo vetor: a promoção de condições de vida digna para todos, horizontalmente. A comunidade internacional, uma entidade abstrata mas que se consolida pela atuação de seus artífices estatais, da sociedade civil, supraestatais, internacionais, capitaneia esforços articulados de declaração e promoção dos direitos humanos. Da necessidade de promoção, proteção, passa a ser demandada a atuação que efetive a proteção por meio da punição individual dos responsáveis pelas maiores violações dos direitos humanos, pois se confia no poder preventivo dos julgamentos: "aqueles que controlam o passado, controlam o futuro. Aqueles quem controlam o presente, controlam o passado", na conhecida frase de George Orwell. Com isso, a revelação da verdade, a preservação da memória e o processamento dos acusados, possibilita-se a prevenção de abusos futuros.

O progresso havido em termos institucionais e no plano da comunhão de valores não pode permitir que se aceite um direito de punir longe dos pressupostos consagrados pela ciência penal para o exercício do poder punitivo. Um direito internacional orientando expansivamente pela proteção dos direitos humanos pode se valer de sua grandiosa missão para exercer o que a opinião pública espera dele: lute contra a impunidade, ainda que isso macule seu dever de ser imparcial e neutro.

${ }^{684}$ V. DELMAS-MARTY, M., “Postface: d'un paradoxe à l'autre”, In: Y. Cartuyvels e outros (org.), Les droits de l'homme bouclier ou épée du droit pénal?, Bruxelas: Bruylant, 2007, p. 615. V., igualmente, TULKENS, F."The paradoxical relationship between criminal law and human rights", JICJ, 2011, p. 577-595.

${ }^{685}$ V. CARTUYVELS, Y. "Droits de l'homme et droit pénal, un retournement? " , In: Y. CARTUYVELS et al. (org.), Les droits de l'homme bouclier ou épée du droit pénal?, op. cit., p. 40. 
Enquanto não se demonstrar que os pressupostos punitivos da comunidade internacional seguem os mesmos padrões de garantia clássicos do direito penal, dificilmente poder-se-á sustentar que as condenações são resultado da aplicação da correta razão jurídica.

c.3) Dispersão e fragmentação. As categorias do direito penal estão sendo manipuladas pelo direito internacional penal com bastante liberdade, assim como as categorias do direito internacional estão sendo manipuladas para permitir a punição dos acusados. Se lembrarmos da forma como o direito penal recebe a norma costumeira, torna clara a diferença entre o direito penal e direito penal internacional. Em direito penal, a norma costumeira fundamenta o afastamento da aplicação de uma norma incriminadora diante de tipos penais anacrônicos. Assim, o costume que amplia o âmbito de liberdade será teleologicamente conforme o princípio da legalidade, reconhecido desde a obra de Francisco de Vitória ${ }^{686}$. Portanto, classicamente o costume em direito penal servia para descriminalizar uma conduta que já não representava um desvalor em determinada sociedade. $\mathrm{O}$ costume, como fonte de direito em direito internacional, classicamente criava um comportamento para os Estados. Em sua versão atualizada, o costume não só descrimaliza e vincula Estados, mas fundamenta punições em direito penal internacional.

Se olharmos para o sistema, superadas as fragilidades da fase inicial do direito penal internacional (questões relacionadas à justiça substancial, interpretação extensiva do tipo penal, fonte costumeira do direito internacional, recurso aos princípios gerais do direito), permanece o uso do direito penal como instrumento de punição mais do que de defesa no âmbito internacional.

Longe de compor um sistema integral no qual o direito penal se insira com os demais elementos de controle social, da pesquisa criminológica, das instituições que legislam e aplicam a lei penal, seu efeito, sua utilidade, seu âmbito de incidência é ético, moral. Não nos opomos às instituições internacionais de proteção dos direitos humanos, mas

\footnotetext{
${ }^{686}$ VITÓRIA, Francisco de. De legibus. Salamanda: Univ. De Salamanda e Univ. de Gênova, 2010, pp. 161 161, citado por BRANDÃO, Cláudio. "Francisco de Vitória e a raiz dogmática do direito penal". In: HOMEM, Antonio Pedro Barbas; BRANDÃO, Cláudio. Do direito natural aos direitos humanos. Coimbra: Almedida, 2014, p. 341: "Artigo Terceiro: se o costume pode ter força de lei e obrigar. Responde que sim e explica como o legislador pode manifestar a sua vontade não somente em palavras, mas também de fato, como, por exemplo, se deixa de castigar os transgressores de uma lei, esta fica derrogada pelo costume".
} 
acreditamos que as matizações propostas indicam um caminho a percorrer, uma forma de recuperar o âmbito de mútua referência entre direito penal e direitos humanos, sendo certo que também quando garantias penais e processuais de acusados são violadas para a condenação por crimes que vitimam a humanidade, também são violados os direitos de toda a humanidade. 


\section{RESUMO}

\section{Priscila Akemi Beltrame. "A Tutela Penal dos Direitos Humanos e o Expansionismo}

Punitivo". 271 páginas, Tese de Doutorado - Faculdade de Direito da Universidade de São Paulo, março/2015.

A expansão do direito penal pelos direitos humanos tem no direito penal internacional um privilegiado campo de estudo. Entre as tendências expansivas dos direitos humanos, motivadas pela luta contra a impunidade, e a necessária contenção mecanismo punitivo, princípios, estruturas de aplicação e fundamentação entram em choque, quando se pensava que os direitos humanos e o direito penal originaram-se da mesma matriz liberal de contenção do poder estatal. O tema ganha especial impulso diante da perspectiva expansionista por que passa o direito penal na modernidade, dos influxos da globalização. As decisões dos tribunais penais internacionais, de Nuremberg a Haia, dos tribunais de direitos humanos (europeu e interamericano), fornecem um panorama de como essa relação tem sido construída, favorecendo a aplicação da norma punitiva e flexibilizando garantias clássicas penais e processuais penais. A discussão empreendida busca matizar a luta contra a impunidade que seja tributária dos avanços jurídicos do sistema de garantias, também conquistas sociais e políticas para a efetiva proteção dos direitos humanos. Nesse contexto, alerta-se para o fato de que se estaria produzindo um direito especial motivado pela luta contra os mais graves crimes contra a paz e a segurança mundiais. Finalmente, expõe-se as dificuldades de validação do conteúdo preventivo das normas em direito penal internacional, do déficit democrático de sua produção desconectada da base social sobre a qual atua, e do efeito simbólico de seus enunciados à custa das máximas garantias.

Palavras-chave: direito penal internacional, direitos humanos, crimes internacionais, crimes de direito internacional, crimes contra a humanidade, expansão do direito penal. 


\section{ABSTRACT \\ Priscila Akemi Beltrame. "The Protection of Human Rights and Expansion of Punitive}

Law". 271 pages, Doctorate Degree - University of São Paulo, Faculty of Law, March/2015.

The international criminal law features a special condition for the critical analysis of the expansion of criminal law through human rights. Between the expansive tendencies of human rights, motivated by the fight against impunity, and the necessary containment of punitive mechanism, stands the international criminal law, whose principles, implementation structures and grounds clash, despite the fact that human rights and criminal law originated from the same liberal matrix for the containment of state power. The debate gained particular momentum with the expansionist perspective experienced by the criminal law in modern times of globalization inflows. The decisions of international criminal courts, from Nuremberg to The Hague, human rights tribunals (European and Inter-American), provide an overview of how this relationship has been built, favoring the application of criminal provisions and easing criminal and criminal procedural classical guarantees. The discussion undertaken shades the fight against impunity, that shall be paved by the legal achievements for the effective protection of human rights, warning to the fact that it is producing a special law, away from the legal domestic law principles, motivated by the fight against the most serious crimes against peace and world security. Finally, sets up the difficulties in accepting the preventive content of international criminal provisions, the democratic deficit of its production disconnected of the social contexts in which operates, and the symbolic effect of its legal provisions at the expense of the maximum guarantees.

Keywords: international criminal law, human rights, international crimes, international law crimes, crimes against humanity, expansion of criminal law. 


\section{RESUMÉÉ}

Priscila Akemi Beltrame. "La protection pénale des droits de l'homme et l'expansionnisme repressif'. 271 pages, Thèse de Doctorat - Faculté de Droit, Université de São Paulo, Mars/2015.

L'expansion du droit pénal par le biais des droits de l'homme dispose dans le domaine du droit pénal international d'un statut de recherche privilégié. Parmi les tendances expansionnistes des droits humains, motivées par la lutte contre l'impunité, l'enceinte de confinement nécessaire du mécanisme punitif, principes et structures de mise en œuvre s'affrontent, malgré le fait que les droits de l'homme et le droit pénal proviennent de la même matrice libérale de confinement du pouvoir de l'Etat. Le débat gagne une intérêt particulier devant la perspective expansionniste connue par le droit pénal durant les temps modernes et la mondialisation. Les décisions des tribunaux pénaux internationaux, de Nuremberg à La Haye, les tribunaux des droits de l'homme (européens et interaméricains), donnent un aperçu de la façon dont cette relation a été construite, en favorisant l'application des dispositions pénales et l'assouplissement des garanties classiques pénales et procédures pénales. La discussion entreprise cherche à nuancer la lutte contre l'impunité, qui est tributaire des réalisations juridiques, aussi conquises pour la protection effective des droits de l'homme. Nous avertissons sur le fait que nous sommes entrain de produire un droit spécial, loin des principes juridiques du droit interne, motivé par la lutte contre les crimes les plus graves contre la paix et la sécurité mondiale. Enfin, le travail expose les difficultés de validation du contenu préventif des normes pénales internationales, du déficit démocratique de sa production déconnecté des contextes de base sociaux ou il agit, et de l'effet symbolique des ses règles au détriment des garanties maximales.

Mots-clés: droit pénal international, droits de l'homme, crimes internationaux, crimes du droit international, crimes contre l'humanité, l'expansion du droit pénal. 


\section{BIBLIOGRAFIA}

ABREU, Maqueda. "Crítica a la reforma penal anunciada". JpD, n. ${ }^{\circ}$ 47, 2003.

AGUILAR, Francisco. Amnistia e constituição. Coimbra: Almedina, 2004.

AKHAVAN, Payan. "Beyond Impunity: Can International Criminal Justice Prevent Future Attrocities?", The American Journal of International Law, 95, 2001.

AKHAVAN, Payan. "Justice in the Hague, Peace in the Former Yugoslavia?", 20, Human Rights Quarterly, 737, 1999.

ALEXANDRINO, José Melo. “A natureza variável dos direitos humanos: uma perspectiva da dogmática jurídica". In: HOMEM, Antonio Pedro Barbas; BRANDÃO, Cláudio. Do direito natural aos direitos humanos. Coimbra: Almedida, 2014.

ALEXY, Robert. Teoría de los Derechos Fundamentales (Trad. por Ernesto Garzón Valdés). Madrid: Centro de Estudios Políticos y Constitucionales, 1993.

ALLEN, Frank. "The erosion of legality in American Criminal Justice: some later-day adventures of the'"nulla poena principle". 29, Arizona Law Review 385, n 1, 1987.

ALVAREZ, José E. "Crimes of States/ Crimes of Hate: Lessons from Rwanda". Yale J. Intl. Law, 365, 1999.

AMBOS, Kai. Temas de derecho penal internacional europeu. Madri: Marcial Pons, 2006

AMBOS, Kai e MALARINO, Ezequiel. "Persecución penal nacional de crímenes internacionales en América Latina. Conclusiones". In: AMBOS, Kai e MALARINO, Ezequiel (org.): Persecución penal nacional de crímenes internacionales en América Latina y España, Montevidéu: Fundación Konrad Adenauer, 2003.

AMBOS, Kai. A parte geral do direito penal internacional: bases para uma elaboração dogmática (Trad. Carlos Eduardo Adriano Japiassú e Daniel Andrés Raizman). São Paulo: Ed. Revista dos Tribunais, 2008.

AMBOS, Kai; BÖHN, María Laura (coords.). Desenvolvimentos atuais das ciências criminais na Alemanha. Gazeta Jurídica: Brasília, 2013.

AMBOS, Kai; MALARINO, Ezequiel; ELSNER, Gisela (eds.), Jurisprudencia Latinoamericana sobre Derecho Penal Internacional, Montevideu: Konrad Adenauer, 2008.

AMBOS, Kai; MALARINO, Ezequiel; ELSNER, Gisela. (eds.) Justicia de transición: com informes de América Latina, Alemania, Italia y España. Konrad-Adenauer Stiftung, Montevidéu, 1996.

AMBOS, Kai; MALARINO, Ezequiel; WOISCHNIK, Jan (eds.). Temas actuales del derecho penal internacional. Montevidéu: Konrad Adenauer, 2005 
AMBOS, Kai; STEINER, Christian. "On the rationale of punishment at the domestic and international level". In: HENZELIN, Marc; ROTH, Robert. Punir les criminels internationaux, Paris: LGDJ, 2002.

AMBOS, Kai; ZILLI, Marcos; ASSIS MOURA, Maria Thereza; MONTECONRADO, Fabíola Girão. Anistia, Justiça e Impunidade - reflexões sobre a Justiça de Transição no Brasil. Belo Horizonte: Ed. Fórum, 2010

ANDRÉS DOMINGUES, A.C., Derecho Penal Internacional. Valência: Tirant monografias, 2006.

ARENAL, Celestino del. "Mundialización, cresciente interdependencia y globalización." Conferencias, Univ. Complutense de Madrid, 2008.

ARROYO ZAPATERO, Luís. "A harmonização internacional do Direito Penal: ideias e processos”. RIBCCRIM, ano $18, \mathrm{n}^{\circ} 84$, maio-jun/2010.

ASCENCION, H.; DECAUX, E.; PELLET, A. Droit International Pénal. CEDIN Parix X. Paris: Pedone, 2000.

ASCENSÃO, José de Oliveira. "A dignidade da pessoa e o fundamento dos Direitos Humanos". In: MIRANDA, Jorge. Estudos em homenagem ao Prof. Doutor Martin de Albuquerque, vol II, Fac. de Direito da Univ. de Lisboa, Coimbra Editora, 2010.

ASCENSÃO, José de Oliveira. "O 'fundamento do direito': entre o direito natural e a dignidade da pessoa”. In: HOMEM, Antonio Pedro Barbas; BRANDÃO, Cláudio. Do direito natural aos direitos humanos. Coimbra: Almedina, 2014.

AVELAR, Idelber. 'Desconstruindo o 'humano' em 'direitos humanos': Vida nua na era da guerra sem fim”, Revista Estudos Políticos, julho/2011.

BACIGALUPO ZAPATER, E. "Jurisdicción penal nacional y violaciones massivas de derechos humanos cometidas en el extrangero". In: El derecho Penal Internacional. Cuadernos de Derecho Judicial. Madri: CGPJ, 2001.

BADIE, B., Un monde sans souveraineté, les Étas entre ruse et responsabilité. Fayard, 1999.

BARATTA, Alessandro. Criminologia crítica e crítica do direito penal. Rio de Janeiro: Ed. Revan, $3^{\text {a }}$ ed., 2002.

BASSIOUI, M. Cherif, Introduction to International Criminal Law. Brill:Nijhoff, 2012.

BASSIOUNI, M. Cherif. "Death Penalty and the Shari'a". International Commission of Jurists, 65, 2000.

BASSIOUNI, M. Cherif. "International criminal justice in the age of globalization". Nouvelles Études Pénales 19, AIDP, 2004.

BASSIOUNI, M. Cherif. "Les crime relevant du prècept de Qesas". 4 Revue Internationale de Criminologie et de Police Technique, 485, 1989. 
BASSIOUNI, M. Cherif. The Statute of ICC: A documentary history. Ardsley-NY: Transnational Publishers, 1998.

BASSIOUNI, M. Cherif. "Universal jurisdiction for International Crimes: Historical Perspectives and Contemporary Practice", 42, Virginia Journal of International Law, 2001.

BASSIOUNI, M. Cherif. Crimes against Humanity in International Criminal Law. The Hague: Kluwer Law, 1999.

BASSIOUNI, M. Cherif.. "El derecho penal internacional: historia, objeto y contenido". $A D P C P$, Oceana Publications, Nova Iorque, 1982

BASSIOUNI, M. Cherif.; MORRIS, Madeleine (eds.). Accountability for International Crimes and Serious Violations of Fundamental Human Rights. 1996.

BAXI, Upendra. The future of human rights. Oxford. Oxford University, 2002.

BAZELAIRE; Jean-Paul; CRETIN, Thierry. A justiça penal internacional - sua evolução, seu future, de Nuremberg a Haia. Barueiri: Ed. Manole, 2004, p. 17

BECCARIA. Dos delitos e das penas. São Paulo: Ed. Revista dos Tribunais, 2011

BECHARA, Ana Elisa Liberatore. "Derechos humanos y límites de la intervención penal en Brasil". RIBCCRIM, ano 18, n 85, jul-ago/2010.

BECHARA, Ana Elisa Liberatore. "Da teoria do bem jurídico como critério de legitimidade do direito penal", mimeo, São Paulo, Tese de Livre Docência, Faculdade de Direito da Universidade de São Paulo, 2010.

BECK, Urich. La sociedad del riesgo mundial. Barcelona: Paidós, 2008.

BENERIA, Lourdes; SARASÚA, Carmen. "Crímenes económicos contra la humanidad", 3/4/2011, disponível em: http://www.sinpermiso.info/textos/index.php?id=4059 (Acesso. 03.10.2014).

BERDUGO GOMEZ DE LA TORRE, I.; PEREZ CEPEDA, A.. "Derechos Humanos y Derecho Penal: Validez de las viejas respuestas frente a las nuevas cuestiones". Revista Penal, no 26, julho, 2010.

BERNHARD, R. (ed). Encyclopedia of Public International Law. Inst. 4, North Holland, 1982.

BILDER, Richard; WILSON, R. "J. Defenses in Contemporary International Criminal Law", 96, AJIL, 2002.

BLOXHAM, D. Genocide on Trial, War Crimes Trials and the Formation of Holocaus History and Memory. Oxford: Oxford University Press, 2001.

BOBBIO, Norberto. "Las razones de la tolerancia". In: BOBBIO, Norberto. El tiempo de los derechos (Trad. Rafael de Así Roig). Madri: Ed. Sistema, 1991. 
BOBBIO, Norberto. El problema del positivismo jurídico (Trad. Ernersto Garzón Valdés). Cid. México: Fontamara, 1991.

BOBBIO, Norberto. El tiempo de los derechos (Trad. Rafael de Así Roig). Madri: Ed. Sistema, 1991.

BONAVIDES, Paulo. Curso de Direito Constitucional. 12. ed. São Paulo: Malheiros, 2002

BOOT, Machteld. Genocide, Crimes against Humanity, War Crimes: Nullum Crimen Sine Lege and the Subject Matter Jurisdiction of the International Criminal Court. Antwerpen: Intersentia, 2002.

BORNEMAN, J. Settling accounts, violence, justice and accountability in postsocialist Europe. 1997.

BOS, Adriaan, "The experience of the preparatory committee". In: POLITI, Mauro; NESI, Giuseppe (eds.), The Rome Statute of the ICC: a challenge to impunity, Ashgate/Dartmouth, Asdershot, 2001.

BOURDIEU, Pierre. O poder simbólico (Trad. Fernando Tomaz). $4^{\mathrm{a}}$ ed., Rio de Janeiro: Bertrand Brasil, 2001.

BRANDÃO, Cláudio. "Francisco de Vitória e a raiz dogmática do direito penal". In: HOMEM, Antonio Pedro Barbas; BRANDÃO, Cláudio. Do direito natural aos direitos humanos. Coimbra: Almedida, 2014.

BRAYARD, F. (ed.). Le génocie des Juifs entre procès et histoire 1943-2000, Bruxelas: Éditions complexe, 2000.

BROOMHALL, “Article 22". In: TRIFFTERER, O. (ed.), Commentary on the Rome Statute of the ICC, Oxford: Oxford Univ. Press, 2008.

BROOMHALL, Bruce. International Justice \& the ICC - between sovereignty and the rule of law. Oxford: Oxford Univ. Press, 2004.

BROTONS, Antonio Remiro. "Agresión, crimen de agresión, crime sin castigo". Documentos 10, Griede.org, Madri, 2005.

BROWLIE, I. Principles of International Law. 5a edição, Claredon Press: Oxford, 1998.

BROWN, Justin. "World facing up to atrocities?", Christian Science Monitor, 16 de fevereiro de 1999.

BRYSK, Alisson (ed.). Globalization and Human Rights. Berkley: University California Press, 2002.

BURCHARD, Christoph. "O princípio da proporcionalidade no direito penal constitucional ou o fim da teoria do bem jurídico tutelado na Alemanha”. In: AMBOS, Kai; BÖHN, Maria Laura (coord.). Desenvolvimentos atuais das ciências criminais na Alemanha. Brasília: Gazeta Jurídica, 2013. 
BUSCHER, Frank M., The US War Crimes Trial Program in Germany, 1946-1955. Westport, CT: Greenwood Press, 1989.

BUSTOS RAMÍREZ, J. Control social y sistema penal. Barcelona: PPU, 1987.

BUSTOS RAMÍREZ, J.. "Los mitos de la ciencia penal del siglo XX: la culpabilidad y la peligrosidad en La Ciencia del Derecho Penal ante el Nuevo Siglo". In: DÍEZ RIPOLLÉS; ROMEO CASABONA; GRACIA MARTÍN; HIGUERA GUIMERÁ (eds.). Libro Homenaje al Profesor Jose Cerezo Mir. Madrid: Tecnos, 2002.

BUSTOS RAMÍREZ, J.. Control social y derecho penal. Barcelona: PPU, 1987.

BUSTOS RAMÍREZ, J.; HORMAZÁBAL MALARÉE, H. Lecciones de derecho penal. vol. 1. Madri, 1997, p. 116.

BUSTOS RAMÍREZ, Juan. Introducción al derecho penal. Bogotá: Temis, 1994.

CALHEIROS. Maria Clara." A crítica aos direitos do homem. Notas à luz das Anarchical Fallacies de Jeremy Bentham". In: HOMEM, Antonio Pedro Barbas; BRANDÃO, Cláudio. Do direito natural aos direitos humanos. Coimbra: Almeida, 2014.

CAMARGO, Antonio Luís Chaves. Sistema de penas, dogmática jurídico-penal e política criminal. Sao Paulo: Cultural Paulista, 2002.

CANCIO MELIÁ, M. “Globalización y Derecho". Anuário de la Facultad de Derecho de la UAM, num. 9, 2005.

CANCIO MELIÁ, Manuel. "Internacionalización del Derecho Penal y de la Política Criminal: algunas reflexiones sobre la Lucha Jurídico-Penal contra el Terrorismo". Apresentado na III Jornadas Jurídicas Luso-Espanholas: Internacionalização do Direito no novo século (ad honorem Jorge de Figueiredo Dias). Univ. de Coimbra, Faculdade de Direito, 24.11.2006.

CANCIO MELIÁ, Manuel. "De nuevo 'Derecho Penal' del enemigo?", In: CANCIO MELIÁ, M.; GÓMEZ-JARA DIEZ, Carlos (eds.), Derecho Penal del Enemigo, el discurso penal de la exclusión, vol. 1, DdeF, 2006

CANOTILHO, José Joaquim Gomes. Direito Constitucional e Teoria da Constituição. ${ }^{\mathrm{a}}$ edição, Coimbra: Almedina, 1993.

CAPELLA HERNÁNDES, J.R. "La naturaleza de la mundialización". In: CAPELLA HERNÁNDES, J.R, Transformaciones del Derecho en la mundialización, Madri: Consejo General del Poder Judicial, 1999.

CAPELLA HERNÁNDEZ, J. R., Transformaciones del derecho en la mundialización. Madri: Consejo General del Poder Judicial, 1999.

CARBONELl (ed.), FERRAJOLI, L. Democracia y Garantismo. Madri: Ed. Trotta, 2010.

CARRILLO SALCEDO, J.A. (Coord.). La criminalización de la barbárie: la CPI. Madri: CGPJ, 2000. 
CARRILlO SALCEDO, J.A. Soberanía de los Estados y Derechos Humanos en Derecho Internacional contemporáneo. Tecnos: Madri, 1995.

CARTUYVELS, Y. et all. Les droits de l'homme bouclier ou épée du droit penal. Bruxelas, Bruylant, 2007.

CARVALHO, Salo de. "Criminologia, Garantismo e Teoria Crítica dos Direitos Humanos". In: ROSILLO MARTÍNEZ, Alejandro (et al., eds.). Teoria crítica dos direitos humanos no século XXI. Porto Alegre: Edipucrs, 2008.

CASSESE, A. et. al. The Rome Statute of the ICC: a Commentary. Oxford: Oxford Univ. Press, 2002.

CASSESE, A., "From Nuremberg to Rome: International Military Tribunals to the International Criminal Court". In: CASSESE, A; GAETA, P.; JONES, J.R.W. The Rome Statute of the International Criminal Court: a Commentary. Oxford: Oxford Univ. Press, 2002.

CASSESE, Antonio. International Criminal Law. Oxford: Oxford University Press. 2a . Ed., 2008.

CASTELLS, Manuel. The Information Age: Economy, Society and Culture. Vol. 1: "The Rise of Network Society". Oxford, 1996.

CEREZO MIR, J. Curso de derecho penal español. Vol I, 6ª ed., Madri, 2004.

CHIHIRO, Hosoya. The Tokyo War Crimes - an International Symposium, 1986.

CHOULIARAS, Athanasios, "Bridging the Gap between Criminological Theory and Penal Theory within the International Criminal System". European Journal of Crime, Criminal Law and Criminal Justice 22, 2014.

COMPARATO, Fabio Konder. A afirmação histórica dos direitos humanos. São Paulo: Ed. Saraiva, 1999.

CRAWFORD, James; KOSKENNIEMI, Martii. The Cambridge Companion to International Law. Cambridge: Cambridge Univ. Press, 2012.

CUESTA, J. L. de la, "Rectos y perspectivas del sistema penal en un mundo globalizado", Revista Académica de la Facultad de Derecho de la Univ. de la Salle, IV, 7, julho, 2006.

D’ÁVILA, Fabio Roberto. "Liberdade e segurança em direito penal. O problema da expansão da intervenção penal". Revista de Estudos Criminais, São Paulo, nº 41, abr.jun./2011.

DAILLIER, P.; PELLET, A. Droit international public. 6ª ed., LGDJ, 1999.

DAMASKA, Mirjan R.. "What is the point of international criminal justice?", Yale Law School, Faculty Scholarship Series, Paper 1573, 2008. 
DANNER e MARTINEZ. "Guilty associations: joint criminal enterprise, command of responsibility, and the development of international criminal law," 93 California Law Review, 2005.

DELMAS-MARTY, M. "Postface: d'um paradoxe à l'autre". In: CARTUYVELS, Y. et al. Les droits de l'homme bouclier ou épée du droit penal, Bruxelas, Bruylant, 2007.

DELMAS-MARTY, M., "O direito penal como ética da mundialização". Revista Portuguesa de Ciência Criminal, A.14, nº 3, Jul./Set. 2004

DELMAS-MARTY, M.. A imprecisão do direito - do código penal aos direitos humanos (Trad. Denise Radanovic Vieira). Ed. Manole: Barueri, 2005.

DELMAS-MARTY, M.. "La CPI et les interactiones entre droit internacional pénal et droit pénal interne à la phase d'ouveture du procès penal". Revue de Science Criminelle et de Droit Pénal Comparé, 3, jul/set, 2005.

DELMAS-MARTY, M.. "Lo relativo y lo universal - Estudios jurídicos comparativos e internacionalización del Derecho" (Trad. Marta M. Morales Romero). Instituto de Derecho Penal Europeo e Internacional. Universidad Castilla-La Mancha, disponível em http://www.college-de-france.fr/media/mireille-delmas-marty/UPL12997__ UPL2491 _rescoursespdm0203.pdf (Acesso 10.11.2014).

DELMAS-MARTY, M.. Três Desafios para um Direito Mundial (Trad. Fauzi Hassan Choukr). Rio de Janeiro: Lumen Juris, 2003.

DELMAS-MARTY, M.. "Un pluralismo ordenado - Estudios jurídicos comparativos e internacionalización del derecho" (Trad. Marta M. Morales Romero), Instituto de Derecho Penal Europeu e Internacional. Universidad Castilla-La Mancha, disponível em www.cienciaspenales.net. (Acesso 15.7.2013)

DELMAS-MARTY, M.; CASSESE, Antonio. Crimes internacionais e jurisdições internacionais. Barueri: Ed. Manole, 2004.

DELMAS-MARTY, Mireille; PIETH, Mark; SIEBER, Ulrich (orgs.). Les chemins de l'harmonisation pénale. Paris: Parution, 2008

DÍEZ SÁNCHEZ, J.J.. El Derecho penal internacional (ámbito espacial de la ley penal). Madri, 1990.

DONELLY, Jack. Universal Human Rights in Theory and Practice. Ithaca: Cornell Univ. Press, 2003.

DONNEDIEU DE VABRES, Henri. Les principes modernes du droit penal international. Sirey, 1928.

DOTTI, René Ariel. Curso de Direito Penal - Parte Geral. $2^{\mathrm{a}}$ ed., Rio de Janeiro: Ed. Forense, 2004

DOWNES, D.; ROCK, P. Understanding deviance: a guide to the sociology of crime and rule breaking. Oxford: Oxford University Press, 3 a ed., 1998. 
DUBBER, M. "Common civility: the culture of alegality in international criminal law". Leiden Journal of International Law, 24, 2011.

EIROA, Otero (Coord.), Memoria y derecho penal. Buenos Aires, 2008

ERNST, G.; HEILINGER, J-C (eds). The Philosophy of Human Rights: Contemporary Controversies, Berlim/Boston: Walter de Gruyter, 2012

ESER, Albin; HASSEMER, Winfried; BURKHARDT, Björn (coord.). MUÑOZ-CONDE, Francisco (coord. Versão espanhola) La ciencia del derecho penal ante el nuevo milênio. Valência: Tirant lo Branch, 2004.

ETCHESON, Craig, After the killing fields: lessons from the Cambodia genocide. Greenwood Publishing Group, 2005.

FARIA COSTA, José. "A Globalização e o Direito Penal (ou o tributo da consonância ao elogio da incompletude. Globalização e Direito". Boletim da Faculdade de Direito, Studia Iuridica 73, Coimbra, 2003.

FARIA, José Eduardo, O direito na economia globalizada. São Paulo: Ed. Malheiros, 2004.

FAVOREAU, Louis; PHILIP, Loïc. Le Conseil Constitutionnel. Paris: PUF, 1985.

FERRAJOLI, L. “La democracia constitucional”. In: CARBONELL (ed.), FERRAJOLI, L. Democracia y Garantismo, Madri: Ed. Trotta, 2010.

FERRAJOLI, L. Derecho y Razón Teoria del garantismo penal (Trad. Perfecto Andrés Ibánez et. al.). Madri: Editoral Trotta, terceira edição, 1997.

FERRAJOLI, L. Derechos y garantías. La ley del más débil. Madri: Ed. Trotta, 1999.

FERRAJOLI, L. A soberania no mundo moderno. São Paulo: Martins Fontes, 2002

FERRAJOLI, L. Criminalidad y globalización (Trad. Miguel Carbonell), 2008, disponível em www.cienciaspenales.net (Acesso 30.7.2014).

FERRAJOLI, L.. Entrevista a Luigi Ferrajoli, por Eduardo Maia Costa/José Mouraz Lopes. Julgar. Coimbra: Wolters Kluwer, set-dez, 2008.

FIGUEIREDO DIAS, Jorge de. Direito Penal - Parte Geral. Ed. Revista dos Tribunais e Coimbra Editora, 2007.

FITZMAURICE et al. (eds.) Treaty interpretation and the Vienna Convention on the Law of Treatis: 30 years on. Leiden: Martinus Nijihoff., 2010.

FLETCHER, Georg. The gramar of Criminal Law. vol. 1. Foundations: Oxford University Press, 2007.

FOLKER, Froebel (et al.), The New International Division of Labor. Cambridge: Cambridge University Press, 1980. 
FRAGOSO, Heleno Claudio. Objeto do crime, Direito Penal e Direitos Humanos. Rio de Janeiro: Ed. Forense, 1977.

FREEMAN, Mark. Truth Commissions and Procedural Fairness. Cambridge, U.P., 2006.

FREI, N. "Le retour du droit en Allemagne. La justice et l'histoire contemporaine après 1'Holocauste - un bilan provisoire". In: BRAYARD, F. (ed.). Le génocie des Juifs entre procès et histoire 1943-2000, 2000.

FREIJOO SÁNCHEZ, Bernardo José (ed.). Derecho Penal de la Culpabilidad y Neurociencias. Civitas, Madri, 2012.

FRISCH, Wolfgang, "Sobre el futuro del derecho penal de la culpabilidad" (Trad. Bernardo J. Freijoo Sánchez). In: FREIJOO SÁNCHEZ, Bernardo José (ed.). Derecho Penal de la Culpabilidad y Neurociencias. Civitas, Madri, 2012.

GALLANT, Kenneth S. "La legalidad como norma del derecho consuetudinario internacional la irretroatividad de los delitos y de las penas". In: MONTIEL, Juan Pablo. La crisis del principio de legalidad en el nuevo derecho penal: ¿decadencia o evolución?.. Madri: Marcial Pons, 2012.

GARIBIAN, Sévane. Le crime contre l'humanité au regard des principes fondateurs de l'Etat moderne: Naissance et consécration d'un concept. Paris: Bruylant, 2007.

GARLAND, D.. “As contradições da 'sociedade punitiva': o caso britânico”. Revista de Sociologia e Politica, 13, 1999.

GIL GIL, Alicia. Derecho penal internacional. Madri: Tecnos, 1999.

GIL GIL, Alicia. "Espanha”. In: AMBOS, Kai; MALARINO, Ezequiel; ELSNER, Gisela (eds.). Justicia de transición: con informes de América Latina, Alemania, Italia y España. Konrad-Adenauer Stiftung, Montevidéu, 1996.

GOLDSTONE, Richard. Carta ao Editor, Wall St. Journal, 7 de julho de 2000.

GOMES, Luis Flávio; MAZZUOLI, Valério de Oliveira. Crimes da ditadura militar. Uma análise à luz da jurisprudência atual da CorteIDH. São Paulo: Ed. Revista dos Tribunais, 2011.

GÓMEZ PAVAJEAU, Carlos Arturo. "La teoría del sujeto de derecho penal”. Derecho Penal y Criminología: Revista del Instituto de Ciencias Penales y Criminológicas, vol. 33, $n^{\circ} .93,2011$.

GOODALE, Mark. The practice of human rights: tracking law between the global and the local. Cambridge: Cambridge Univ. Press, 2003.

GRAMMER, Christoph. "El sistema del Estatuto de Roma como fuerza motriz del derecho penal internacional. El inesperado éxito del Estatuto de Roma en América Latina". In: AMBOS, Kai; MALARINO, Ezequiel; WOISCHNIK, Jan (eds.). Temas actuales del derecho penal internacional. Montevidéu: Konrad Adenauer, 2005. 
GRECO, Rogério. Curso de Direito Penal - Parte Geral. $4^{\mathrm{a}}$ ed. Rio de Janeiro: Impetus. 2004.

GROVER, Lena. "A Call to Arms: Fundamental Dilemmas Confronting the Interpretation of Crimea". The European Journal of International Law, vol. 21, nº 3, 2010.

HABERMAS, Jurgen. The Crisis of the European Union: A Response. Cambridge, UK: Polity Press, 2012.

HABERMAS, Jurgen. Die Zeit, de 29 de abril de 1999.

HASSEMER, Winfred. "Lineamentos de una teoría personal del bien jurídico" (Trad. Patrícia S. Ziffe). Doctrina Penal 12, 1989.

HASSEMER, Winfred. "La autocomprension de la ciencia del derecho penal frente a las exigencias de su tiempo" (Trad. Maria del Mar Díaz Pita). In: MUÑOZ CONDE, Francisco (Coord.). La ciencia del derecho penal ante el nuevo milénio. Valência: Tirant lo Blanch, 2004.

HASSEMER, Winfred. Persona, mundo y responsabilidad. Bases para una teoría de la imputación en Derecho Penal (Trad. Muñoz Conde e Díaz Pita). Valência: Tirant lo Blanch, 1999.

HASSEMER, Winfred. "Warum und zu Wlschem End Strafen Wir?”, 30, Zeitschrift für Rechtspolitik, 316, 1997.

HATTENHAURER, Hans. Los fundamentos histórico-ideológicos del derecho alemán. Madri: Editoriales de Derecho Reunidas, 1981.

HELFER, Laurence R. "Forum Shopping for Human Rights". University of Pensylvania Law Review, 148(2), 285, 1999.

HELFER, Laurence R. "Overlegalizing Human Rights: International Relations Theory of the Commonwealth Caribbean Backlash Against Human Rights Regimes". Columbia Law Review, 102:1832, 2002.

HENZELIN, M., Le principe de l'université en droit penal internacional. Bruxelas: Bruylant, 2000.

HENZELIN, Marc; ROTH, Robert. Punir les criminels internationaux. Paris: LGDJ, 2002.

HERRERA FLORES, Joaquín. "Cultura y derechos humanos: la construcción de los espacios culturales". In: ROSILLO MARTÍNEZ, Alejandro (et. al.). Teoría Critica dos Direitos Humanos no Séc. XXI, Porto Alegre: Edipucrs, 2008.

HIRSCH, H. J. "Internacionalización del derecho penal y de la ciencia del derecho penal nacional y universal”. Revista de Derecho Penal, 17, 2006.

HOLMES, “The Principle of Complementarity". In: LEE, R.S. (ed.), The ICC: the making of the Rome Statute, 1999. 
HOMEM, Antonio Pedro Barbas; BRANDÃO, Cláudio. Do direito natural aos direitos humanos. Coimbra: Almedida, 2014.

HORMAZÁBAL MALARÉE, Hernán. Bien jurídico y Estado social y democrático de derecho. Madri: Ed. Trotta, 1991.

HUSARBO, R. J.; STRANDBAKKEN, A.. Harmonization of Criminal Law in Europe. Oxford: Intersentia, 2005.

IANNI, Octavio. A Era do Globalismo. Rio de Janeiro: Ed. Civilização Brasileira, 1997.

IGNATIEFF, Michel. Los derechos humanos como política e idolatría. Barcelona: Paidós Estado y Sociedad 108, 2003.

JAKOBS, Günther; CANCIÓ MELIÁ, Manuel. Derecho Penal del Enemigo. Madri: Civitas. 2003.

JAPIASSÚ, Carlos Eduardo Adriano (org.). O direito penal internacional. Belo Horizonte: Ed. Del Rey, 2009.

JAPIASSÚ, Carlos Eduardo Adriano. $O$ Tribunal Penal Internacional $-a$ internacionalização do direito penal. Rio de Janeiro: Lumen Juris, 2004.

JAPIASSÚ, Carlos Eduardo Adriano. "O princípio do ne bis in idem no direito penal internacional". Revista da Faculdade de Direito de Campos, Ano IV, № 4 e Ano V, No 5 , 2003-2004.

JARDIM, Tarciso dal Maso. "A contribuição da justiça internacional penal: formação de paradigmas". Revista Anistia, vol. 9.

JESCHECK, H.H. "Nuremberg Trials". In: BERNHARD, R. (ed). Encyclopedia of Public International Law. Inst. 4, 1982.

JESCHECK, Hans Heinrich. Die Verantworlichkeit der Staatsorgane nach Völkerstrafrecht, L. Röhrscheid, 1952.

JIMÉNEZ DE ASUA, Luís. Tratado de derecho penal. t. II, Buenos Aires: Losada, 1957.

JOYNER, C., "Reigning Impunity for International Crimes and Serious Violations of Fundamental Human Right: Proceedings of the Siracusa Conference", 1998, Nouvelles Études Pénales, pp. 225-227; Truth and Reconciliation Commission of South Africa Report (5 vols.), Londres: Macmillan, 1998.

KELSEN, Hans, "Collective and Individual Responsibility in International Law with Particular Regard to the Punishment of War Criminals". California Law Review, 1942-43.

KENNEDY, David. The dark sides of virtue: reassessing international humanitarism. Nova Jersey, Princeton Univ. Press. 1999.

KOSKENNIEMI, Martii. "Between impunity and show trial”. Max Planck UNYB, 6, 2002. 
KOSKENNIEMI, Martii. "Hersh Lauterpacht and the Development of International Criminal Law". Journal of International Criminal Justice, 2, 2004.

KOSKKENIEMI, Martii. "The Lady Doth Protest too much Kosovo and the turn to Ethics in International Law". The Modern Law Review, vol. 65, n² 2, março 2002.

KREVER, T. "International Criminal Law: an ideology critique". Leiden Journal of International Law, 26, 2013.

KÜHL, Kristian. Festschrift für Spendel, 1992.

KUHLEN, Lothar. "La autocomprensión de la ciencia del derecho penal frente a las exigencias de su tiempo". In: ESER, Albin; HASSEMER, Winfried; BURKHARDT, Björn (coord.); MUÑOZ-CONDE, Francisco (coord. versão espanhola). La ciencia del derecho penal ante el nuevo milenio. Valência: Tirant lo Blanch, 2004.

KUHLEN, Lothar. "Sobre la relación entre mandato de certeza y la prohibición de la analogía". In: MONTIEL, Juan Pablo. La crisis del principio de legalidad en el nuevo derecho penal: ¿decadencia o evolución?, Madri: Marcial Pons, 2012.

LAFER, Celso. "A reconstrução dos direitos humanos: a contribuição de Hannah Arendt". Revista de Estudos Avançados, vol.11, no.30, São Paulo, Maio/Agosto, 1997.

LAMB, Susan. "Nullum crimen, nulla poena sine lege in International Criminal Law". In: CASSESE, Antonio et al. (eds.). The Rome Statute of the ICC: a Commentary, 2002.

LEBEN, Charles. "The changing structure of international law revisited. By way of introduction". EJIL, 1997

LEE, Roy. The International Criminal Court, the Making of the Rome Statute, Issues, Negotiations and Results. Haia: Kluwer Law International, 1999.

LISZT, Franz von. Das Strafrecht der Staaten Europas. Berlinm, 1894.

LISZT, Franz von. The Purpose of Thought in Criminal Law. Berlin 1882/83.

LOMBOIS, Claude. Droit penal international. $2^{\mathrm{a}}$ ed., Dalloz, Paris, 1979.

MACHADO, Maíra R. Internacionalização do direito penal. Ed. 34: São Paulo, 2004.

MACHADO, Marta R. A Sociedade de risco e direito penal: Uma avaliação de novas tendências político-criminais. São Paulo: Ibccrim, 2005.

MALARINO, Ezequiel. "Activismo judicial, punitivización y nacionalización: tendencias antidemocráticas y antiliberales de la CIDH". In: Derechos humanos y derecho penal. Bogotá: Pontificia Universidad Javeriana/ Grupo Editorial Ibáñez, 2012.

MALARINO, Ezequiel. "Jurisprudencia Latinoamericana sobre Derecho Penal Internacional". In: AMBOS, Kai; MALARINO, Ezequiel; ELSNER, Gisela (eds.). Jurisprudencia Latinoameriana sobre Derecho Penal Internacional. Montevideu: Konrad Adenauer, 2008. 
MALARINO, Ezequiel. "Problemas de determinación de la norma penal y soluciones de interpretación en textos penales plurilingües en el ejemplo el Estatuto de Roma". In: AMBOS, Kai; MALARINO, Ezequiel; WOISCHNIK, Jan (eds.). Temas actuales del derecho penal internacional. Montevidéu: Konrad Adenauer, 2005.

MAQUEDA ABREU, Maria Luisa. "Crítica a la reforma penal anunciada", $J p D, \mathrm{n}^{\circ} 47$, 2003.

MARTIN-CHENUT, Kathia. "A valorização das obrigações positivas de natureza penal na jurisprudência da CIDH: o exemplo das graves violações de direitos humanos cometidas durante as ditaduras dos países do Cone-Sul" (trad. Priscila Akemi Beltrame e Pedro Augusto Simões da Conceição). RIBCCRIM 103, 2013.

MARTIN-CHETNUT, Kathia. "Direito à verdade e justiça de transição: a contribuição do sistema interamericano de proteção dos direitos humanos”. Revista Anistia 9, 2014.

MASLOW, Abraham. “A Theory of Human Motivation”. Psycological Review, 1943, 50.

MASON, R. "Les premiers cas d'application des dispositions pénales des Conventions de Genève par les jurisdictions internes”. European Journal of International Law, 1995.

MCADAMS, A. James (Ed.), Transitional Justice and the Rule of Law in New Democracies. Univ. Notre Dame Press, Indiana, 2001.

MÉNDEZ, Juan E. "In defense of transitional justice". In: MCADAMS, A. James (Ed.), Transitional Justice and the Rule of Law in New Democracies, Univ. Notre Dame Press, Indiana, 2001.

MENEZES, Wagner. Tribunais Internacionais - Jurisdição e Competência. Ed. Saraiva: São Paulo, 2013.

MENON, Theodore. "The humanization of humanitarian law". AJIL, 94, 2000.

MERON, Theodor. Human Rights and Humanitarian Norms as Customary Law. Oxford: Clarendon Press, 1989.

MERON, Theodore. "From Nuremberg to the Hague". 149, Military Law Review, 107, 1995.

MINIUCI, Geraldo. "O genocídio e o crime de genocídio”. RIBCCRIM nº 84, mar-abr/2010.

MIRANDA RODRIGUES, Anabela; LOPES DA MOTA, José Luís. Para uma política criminal europeia. Quadro e instrumentos da cooperação judiciaria em matéria penal no espaço da União Europeia. Coimbra: Coimbra Editora, 2002.

MONTIEL, Juan Pablo. "La 'mala costumbre' de vulnerar derechos humanos: análisis y pronóstico de la costumbre como fuente del DPI". In: MONTIEL, Juan Pablo. La crisis del principio de le galidad en el nuevo derecho penal: ¿decadencia o evolución?, Madri: Marcial Pons, 2012.

MONTIEL, Juan Pablo. La crisis del principio de legalidad en el nuevo derecho penal: ¿decadencia o evolución? Madri: Marcial Pons, 2012. 
MORALES PRATS, Fermín, "Funciones del derecho penal y sociedad civil". Il Dirito Penale alla svolta di fine millenio, Torino: Giappichelli Editore, 1998.

MORILLAS CUEVA, Lorenzo. "Reflexiones sobre el derecho penal del futuro." Revista Electrónica de Ciencia Penal y Criminología, 0406, 2002.

MOYNIER, Gustav. Note sur la crèation d'une institution judiciaire internationale propre à prevenir et a réprimer les infrations à la Convention de Genève. Genebra: Soulier et Wirth, 1872.

MULLINS, C.W.; ROTHE, D. "The ability of ICC to deter violations of international criminal law: a theoretical assessment", International Criminal Law Review, 10, 2010.

MUÑOZ CONDE, Francisco. Derecho penal, Parte Especial. $11^{\mathrm{a}}$ Ed., Valência: Tirant lo Blanch, 1996.

MUÑOZ CONDE, Francisco (Coord.). La ciencia del derecho penal ante el nuevo milenio. Valencia: Tirant lo Blanch, 2004.

NEVES, Marcelo. Entre Têmis e Leviatã: uma relação difícil. O Estado Democrático a partir e além de Luhmann e Habermas. São Paulo: Martins Fontes, 2008.

NIJHOFF, Martinus, The Structure and Process of International Law. The Hague, 1983.

NOLLKAEMPER, André; VAN DER WILT, Harmen. System criminality in international law: conclusions and outlook. Janeiro, 2009.

NOUWEN, Sarah. "Justifying justice". In: CRAWFORD, James; KOSKENNIEMI, Martii. The Cambridge Companion to International Law. Cambridge: Cambridge Univ. Press, 2012.

NOUWEN, Sarah; LEWIS, Dustin. "Jurisdictional Arrangements and International Criminal Procedure". In: SLUITER, Gorang. International Criminal Procedure. Oxford: Oxford University Press, 2011.

ORENTLICHER, Diane F. "Criminalizing Hate Speach in the Crucible of Trial: Prossecutor vs. Nahimana". American University International Law Review, n² 21, v. 4.

PACE, William; THEIROFF, Mark. "Participation of NGOs". In: LEE, Roy. The International Criminal Court, the Making of the Rome Statute, Issues, Negotiations and Results. Haia: Kluwer Law International, 1999.

PACKER, Herbert. The limits of the criminal sanction. Stanford: Stanford Univ. Press, 1968.

PALAZZO, Francesco. "Principios fundamentales y opciones político-criminales en la tutela penal del ambiente en Italia”. Revista Penal, n 4, 1999.

CHOULIARAS, Athanasios. "Bridging the Gap between Criminological Theory and Penal Theory within the International Criminal System". European Journal of Crime, Criminal Law and Criminal Justice 22, 2014, p. 250.

PASTOR, D. El poder penal internacional. Una aproximación jurídica crítica a los fundamentos del Estatuto de Roma. Barcelona: Atelier, 2006. 
PASTOR, D.R. "Procesos penales sólo para conocer la verdad? La experiencia argentina". In: EIROA, Otero (Coord.), Memoria y derecho penal, Buenos Aires, 2008.

PASTOR, Daniel R. (dir.). El sistema penal en las sentencias recientes de los órganos interamericanos de protección de los derechos humanos. Buenos Aires: Ad-Hoc, 2013.

PELLA, Vespasian. La Guerre-Crime et les Criminels de Guerre. Paris, 1946.

PELLET, “Applicable Law", In: CASSESE, Antonio et al. (eds). The Rome Statute of the ICC: a commentary, 2002.

PETIT GABRIEL, E. "La propuesta de un tribunal penal internacional de Gustave Moynier, un proyeto antiguo recientemente rescatado". In: CARRILLO SALCEDO, Juan Antonio (Coord.). La criminalización de la barbárie: la CPI. Consejo General del Poder Judicial, Madri, 2000.

PIRES, Álvaro. “A racionalidade penal moderna, o público e os direitos humanos". Novos Estudos, Cebrap, vol. 68, marco/2004.

POLITI, Mauro; NESI, Giuseppe (eds.). The Rome Statute of the ICC: a challenge to impunity. Ashgate/Dartmouth, Asdershot, 2001.

PRADELLE, G. de la, "La competence universelle". In: ASCENSIO, H. DECAUX E. e PELLET, A. (ed.), Droit Internacional Pénal. Paris: Pedone, 2000.

PRITTWITZ, Cornelius. "A função do direito penal na sociedade globalizada do risco defesa de um papel necessariamente modesto". In: AMBOS, Kai; BOHN, Maria Laura (coords.). Desenvolvimentos atuais das ciências criminais na Alemanha. Brasília: Gazeta Jurídica, 2013.

QUINN, Joanna. Reconciliation(s): Transitional Justice in Postconflict Societies (Studies in Nationalism and Ethnic Conflict). McGill Queen’s University Press, 2009

Quintano Ripollés, A. Tratado de derecho penal internacional. Parte General I, 1956.

RAMOS, André de Carvalho. "Mandados de criminalização no direito internacional dos direitos humanos: novos paradigmas da proteção das vítimas de violações de direitos humanos". RIBCCRIM 62, 2006.

RAMOS, André de Carvalho. "Crimes da ditadura militar: a ADPF 153 e a CorteIDH". In: GOMES, Luis Flávio; MAZZUOLI, Valério de Oliveira. Crimes da ditadura militar. Uma análise à luz da jurisprudência atual da CorteIDH. São Paulo: Ed. Revista dos Tribunais, 2011.

Ramos, André de Carvalho. "Pluralidade das ordens jurídicas: uma nova perspectiva na relação entre o Direito Internacional e o Direito Constitucional”. Revista da Faculdade de Direito da USP, v. 106-107, jan/dez 2011/2012

REALE JÚNIOR, Miguel, Teoria do Delito. São Paulo: Ed. Revista dos Tribunais, 1998. 
REALE JÚNIOR., Miguel. "A Comissão Especial de Reconhecimento dos Mortos e Desaparecidos Políticos". In: TELES, Janaína. Mortos e Desaparecidos Políticos: Reparação ou Impunidade?. São Paulo: Humanitas, 2001.

REALE JÚNIOR, Miguel. “Razão e subjetividade”. Ciências Penais, vol. 00, 2004.

REALE, Miguel. Lições Preliminares de Direito, 27ª ed. São Paulo: Saraiva. 2002.

REDRESS, 'La Compétence Extraterritoriale dans l'Union Européenne - Étude des Lois et des Pratiques dans les 27 États Membres de l'Union Européenne”, dez. 2010.

RICOEUR, Paul. La mémoire, l’histoire, l'oubli. Paris: Édititions du Seuil, 2000.

ROACH, K. "Four models of the criminal process". 89, Journal of Criminal Law and Criminology, 1999.

ROBBENNOLT, J. K. "Outcome severity and judgments of 'responsibility': a metaanalytical review”. 30, Journal of Applied Social Psychology 2575, 2000.

ROBERTS, Adam. "The Laws of War: problems of implementation in contemporary conflicts". 6, Duke J. Comp. and Intl. Law, 11, 1995.

ROBERTS, Paul; MCMILLAN, Nesam. "For criminology in International Criminal Justice". Journal of International Criminal Justice, 1, 2003.

ROBERTSON, Geoffrey. Crimes Against Humanity - The Struggle for Global Justice. Alan Lane: Penguin, 1999.

ROBINSON, D. "Serving the interests of justice: Amnesties, Truth Commissions and the International Criminal Court”. European Journal of International Law, 2003.

ROBINSON, D., "The identity crisis of international criminal law". Leiden Journal of International Law, 21, 2008.

ROHT-ARRIAZA, Naomi (ed.). Impunity and Human Rights in International Law and Practice. Oxford: Oxford Un. Press, 1995.

RÖLING, B.V.A., The Tokyo Trial and Beyond, Reflections of a Peacemonger. Polity Press, Cambridge, 1993.

ROSILLO MARTÍNEZ, Alejandro (et al., eds.). Teoria crítica dos direitos humanos no século XXI. Porto Alegre: EdiPUCRS, 2008.

ROTHE, D.; COLLINS, V.E. “The ICC: a pipe dream to end impunity?”, 13, International Criminal Law Review, 13, 2013.

ROXIN, Claus. Derecho Penal - Parte General, T. 1 (Trad. Diego-Manuel Luzón Peña, Miguel Díaz y García Conlledo e Javier de Vicente Remesal), Civitas, Madri, 1997.

RUDASINGWA, Theogene. "The Rwanda Tribunal and its Relationship to National Trials in Rwanda”. 13, American University International Law Review, 1469, 1998. 
RUDOLPHI, Hans-Joachim. RZP, 1979.

SAAD-DINIZ, Eduardo. "El enclave de los juicios de transición: observación del caso brasileño". Revista de derecho penal y procesal penal, 12, 2011.

SAAD-DINIZ, Eduardo. "Fronteras del normativismo: a exemplo de las funciones de la información en los programas de criminal compliance". Rev. Faculdade de Direito da Univ. de São Paulo. v. 108, jan/dez, 2013.

SAAD-DINIZ, Eduardo. Inimigo e pessoa no direito penal. São Paulo: LiberArs, 2012.

SALVADOR NETTO, Alamiro Velludo. "Finalidades da Pena, Conceito Material de Delito e Sistema Penal Integral". Tese de Doutorado, FADUSP, 2008.

SANTOS, Boaventura Sousa. A Globalização e as Ciências Sociais, São Paulo: Ed. Cortez, 2002.

SCHABAS, W. "Sentencing by International Tribunals: A Human Rights Approach". Duke Journal of Comparative and International Law, 7, 1997.

SCHÄUBLE, Wolfgang. Zeitschrift für Rechtspolitik, 2006

SEN, Amartya. "Human rights and the limits of law". Cardozo Law Review, 2005-2006, 27.

SEWALL, Sarah B.; KAYSEN, Carl (eds.), The United States and the ICC: National Security and International Law. Nova Iorque: Rowan Lishers, 2000.

SHABAS, W. "Interpreting the Statutes of the Ad Hoc Tribunals". In: VOHRAH, L.C. (ed.), Man's Inhumanity to Man: Essays on international law in honour of Antonio Cassese, 2003.

SHAW, Mark; van DIJK, Fan; RHOMBERG, Wolfgang. "Determining trends in global crime and justice: an overview of results from the united nations surveys of crime trends and operations of criminal justice systems". Disponível em: http://www.unodc. org/pdf/crime/forum/forum3_Art2.pdf (Acesso 30.08.2014).

SIEBER, Ulrich, "The forces behind the harmonization of criminal law". In: DELMASMARTY, Mireille; PIETH, Mark; SIEBER, Ulrich (orgs.). Les chemins de l'harmonisation pénale. Paris: Parution, 2008

SILVA SÁNCHEZ, Jesús-María. "Nullum crimen sine poena? sobre las doctrinas penales de la "lucha contra la impunidad" y del "derecho de la víctima al castigo del autor". Universidad Externado de Colombia, 2008.

SILVA SÁNCHEZ, Jesús-María. A expansão do Direito penal: aspectos da política criminal nas sociedades pós-industriais. São Paulo: Revista dos Tribunais, 2002 (Série as Ciências Criminais no Século XXI; v. 11).

SILVA SANCHEZ, Jesús-María. La expansión del derecho penal: Aspectos de la política criminal en las sociedades postindustriales. Madri: Civitas, $2^{\text {a }}$ ed., 2001.

SILVEIRA, Renato de Mello Jorge da. "Labirinto penal e o caso brasileiro: a tensão entre o sistema nacional e o sistema internacional na tutela dos direitos humanos". In: HOMEM, 
Antonio Pedro Barbas; BRANDÃO, Cláudio. Do direito natural aos direitos humanos. Coimbra: Almedina, 2014.

SILVEIRA, Renato de Mello Jorge. Direito Penal Supra-individual, Interesses Difusos. São Paulo, RT, 2003.

SIMESTER, A.P.; SULLIVAN, G.R. Criminal Law: Theory and Doctrine 38, Oxford: Hart Publishing, 2003.

SIMMA, B.; ALSTON, P. "The process of law-making is thus turned into a self-contained exercise in rhetoric". Austr. Y.B.I.L., vol. 12, 1992.

SIMMA, B.; ALSTON, P. "The Sources of Human Rights Law: Custom, Jus Cogens and General Principles", Austr. Y.B.I.L., vol. 12, 1992.

SIMMA, B.; PAULUS, A. "Le rôle relatif des différentes sources du droit international pénal (dont les príncipes généraux de droit)". In: ASCENCION, H.; DECAUX, E.; PELLET, A. Droit International Pénal. CEDIN Parix X. Paris: Pedone, 2000.

SIMMA, B.; PAULUS, A.L. "The international community: facing the challenge of globalization”, 9, European Journal of International Law, 1998.

SIMMONS, Beth A. Mobilizing for human rights - international law in domestic politics. Cambridge: Cambrige Univ. Press, 2009.

SIMPSON, G. "Men and abstract entities: individual responsibility and collective guilt in international criminal law". In: NOELLKAEMPER, A; VAN DER WILT, H. (eds.). System Criminality in International Law. Cambridge: Cambridge Univ. Press, 2009.

SINGER, Peter, Un solo mundo. La ética de la globalización. Paidós: Barcelona, 2002.

SLUITER, Gorang. International Criminal Procedure. Oxford: Oxford University Press, 2011.

SOUZA SANTOS, Boaventura de. A Globalização e as Ciências Sociais. São Paulo: Ed. Cortez, 2002.

SOUZA, Luciano Anderson de. Expansão do Direito Penal e Globalização. São Paulo: Quartier Latin, 2007.

STERNBERG-LIEBEN, Detlev. "Bien jurídico, proporcionalidad y libertad del legislador penal”. In: Hefendehl, Roland. La teoria del bien jurídico: ¿Fundamento de legitimación del derecho penal o juego de abalorios dogmático?. Madrid: Marcial Pons, 2007.

STIGLITZ, Joseph, El mal estar en la globalización (Trad. Carlos Rodríguez Braun). Madrid: Taurus, 2002.

STRENGER, Irineu. Direito Internacional Privado. Vol. 1. São Paulo: Ed. Revista dos Tribunais, 1986.

SWART, Mia. "Is There a Text in This Court? The Purposive Method of Interpretation and the ad hoc Tribunals". Zä̈RV, 70, 2010. 
SWENSSON JUNIOR, Lauro Joppert. Anistia penal. Problemas de validade da Lei de Anistia Brasileira (Lei 6.683/79). Curitiba: Juruá, 2011.

SZUREK, S. "Historique de la a formation du droit international pénal". In: ASCENSIO, H.; DECAUX, E. e PELLET, A. (org). Droit Internacional Pénal. Paris: Pedone, 2000.

TALLGREN, I. "The sensibility and sense of international criminal law". EIJIL, 12, 2002.

TAMARIT SUMALLA, Josep (coord.). Justicia de transición, justicia penal internacional y justicia universal, Atelier, 2010.

TAMARIT SUMALLA, Josep. "Justicia penal, justicia reparadora y comisiones de la verdad". In: TAMARIT SUMALLA, Josep (coord.). Justicia de transición, justicia penal internacional y justicia universal, Atelier, 2010.

TAMARITT SUMALLA, Josep; VILLACAMPA ESTIARTE, Carolina. Victimología, justicia penal y justicia reparadora. Ed. Ibáñez; Bogotá, 2006.

TASIOULA, John. "On the Nature of Human Rights". In: ERNST, G.; HEILINGER, J-C (eds). The Philosophy of Human Rights: Contemporary Controversies. Berlim/Boston: Walter de Gruyter, 2012.

TAYLOR, Telford. The anathomy of Nuremberg Trials. A personal memoire. Nova Iorque, 1992.

TEITEL, Rutti G. “Transitional Justice Genealogy”. Harvard Human Rights Journal, vol. 16, 2003.

TEITELBAUM, A. "Statute of the ICC: a critique". Social Justice, 26, 1999.

TELES, Janaína. Mortos e Desaparecidos Políticos: Reparação ou Impunidade?. São Paulo: Humanitas, 2001.

TERRADILLOS BASOCO, "El derecho penal de la globalización: luces y sombras". In: CAPELLA HERNÁNDEZ, J. R., Transformaciones del derecho en la mundialización: la naturaliza de la mundialización”. Madri: Consejo General del Poder Judicial, 1999.

TICEHURST, R. "The Advisory Opinion of the International Court of Justice on the legality of the threat or use of nuclear weapons". War Studies Journal, Outono, 2, 1, 1996.

MENEZES, Tobias Barreto de. Menores e loucos. Fundamentos sobre o direito de punir. Edições do Estado do Sergipe, 1926.

TOMUSCHAT, C. "La cristallisación coutumière". In: ASCENCION, H.; DECAUX, E.; PELLET, A. Droit International Pénal. CEDIN Parix X. Paris: Pedone, 2000.

TRIFFTERER, O. (ed.), Commentary on the Rome Statute of the ICC. Munique: Beck, Hart, Nomos,2008.

TRIFFTERER, O. "Völkerstrafrecht im Wandel?”. Fertschrift für Hans-Heinrich Jescheck zum 70 Geburtstag, t. II, 1985. 
TULKENS, F.," The paradoxical relationship between criminal law and human rights". JICJ, 2011.

TYLER, Tom R. Why people obey the law. New Haven, Yale Univ. Press, 1990.

URIOS MOLINER, Santiago. "Antecedentes históricos de la CPI". In: GÓMEZ COLOMER; GONZÁLEZ CUSSAC; CARDONA LLORENS. La Corte Penal Internacional - un estudio interdisciplinar. Valência: Tirant lo Blanch, 2003.

VAGG, J. 'Context and Linkage: reflections on comparative research and 'internacionalism' in criminology". 33, British Journal of Criminology, 1993.

VAN ZYL, Paul. "Dilemmas of Transitional Jusitce: The Case of South Africa's Truth and Reconciliation Commission”, 52 J. International Affairs, 647, 1999.

VASAK, Karel, Human Rights: “A Thirty-Year Struggle: the Sustained Efforts to give Force of law to the Universal Declaration of Human Rights". UNESCO Courier 30:11, Paris: United Nations Educational, Scientific, and Cultural Organization, Novembro, 1977.

VERGÉS RAMÍREZ, Salvador. Derechos humanos: fundamentación. Madri: Tecnos, 1997.

VERHOEVEN, J. “Vers um ordre répressif universel?”. AFDI, 45, 1999.

VIADA, Natacha G. Derecho Penal y Globalización. Madri: Marcial Pons, 2005.

VITÓRIA, Francisco. De legibus. Salamanda: Univ. De Salamanda e Univ. De Gênova, 2010 .

VOGEL, Joachim. "Derecho Penal y Globalizacion" (Trad. Manuel Cancio Meliá). AFDUAM, 9, 2005.

VOHRAH, L.C. (ed.), Man's Inhumanity to Man: Essays on international law in honour of Antonio Cassese, 2003.

WELZEL, Hans. El nuevo sistema del derecho penal; una introducción a la doctrina de la acción finalista (Trad. José Cerezo Mir), Barcelona: Ariel, 1964.

WERLE, Gerhard. Tratado de derecho penal internacional, Valência: Ed. Tirant lo Blanch, 2011.

WESTERN, Peter. "Two rules of legality in criminal law". Law and Philosophy, vol. 26(3), 2007.

WIPPMAN, David. "Atrocities, deterrence, and the limits of International Justice". Fordahm International Law Journal, vol. 23, 2, 1999, 480.

YÁNEZ-BARNUEVO, Juan Antonio. "La Conferencia de Roma y el Estatuto de la Corte Penal Internacional: balance y perspectivas". In: Creación de una jurisdicción penal internacional, Colección Escuela Diplomática nº 4, Madri, 2000.

YASUANI, Onuma. "The Tokyo Trial: between Law and Politics". In: CHIHIRO, Hosoya. The Tokyo War Crimes - an International Symposium, 1986. 
ZAFFARONI, Eugenio Raúl; ALAGIA, Alejandro; SLOKAR, Alejandro. Derecho Penal: Parte General. $2^{\mathrm{a}}$ ed., Buenos Aires: Ediar, 2002.

ZAFRA ESPINOSA DE LOS MONTEROS, Rafael. "El establecimiento convencional de la CPI: grandes y servidumbres". In: CARRILLO SALCEDO, J.A. (Coord.). La criminalización de la barbarie: la CPI. Madri: CGPJ, 2000.

ZEDNER, L. Criminal Justice. Oxford: Oxford University Press, 2004.

ZILLI, Marcos. "Punir or not punir? Qual é o verdadeiro dilema?". Revista Anistia 9, 2014.

ZILLI, Marcos; ASSIS MOURA, Maria Thereza; MONTECONRADO, Fabíola Girão. “A Justiça de Transição no Brasil - um caminho ainda a percorrer". In: AMBOS, Kai; ZILLI, Marcos; ASSIS MOURA, Maria Thereza; MONTECONRADO, Fabíola Girão. Anistia, Justiça e Impunidade - reflexões sobre a Justiça de Transição no Brasil. Belo Horizonte: Ed. Fórum, 2010. 